
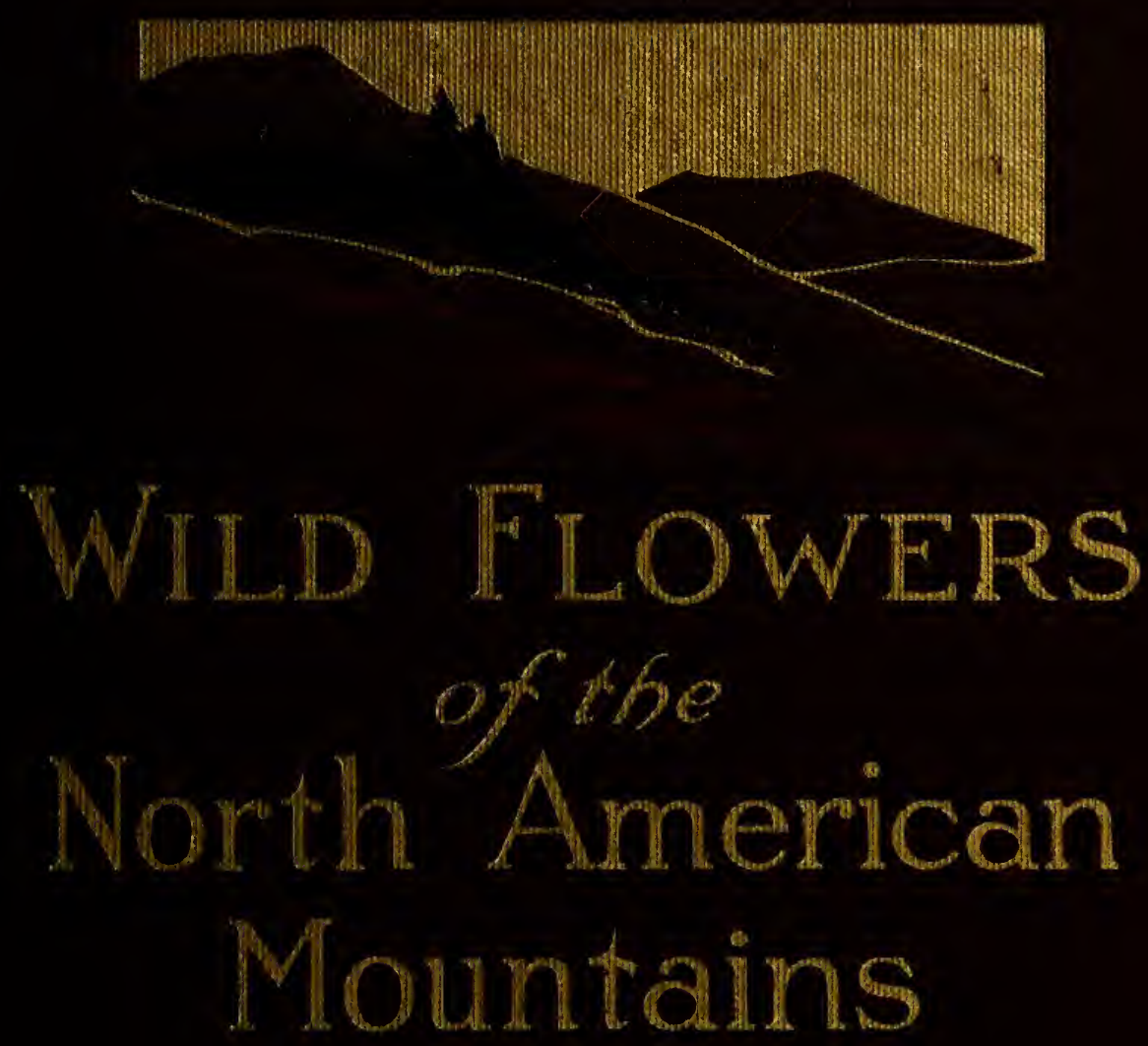

Julia W. Henshaw 


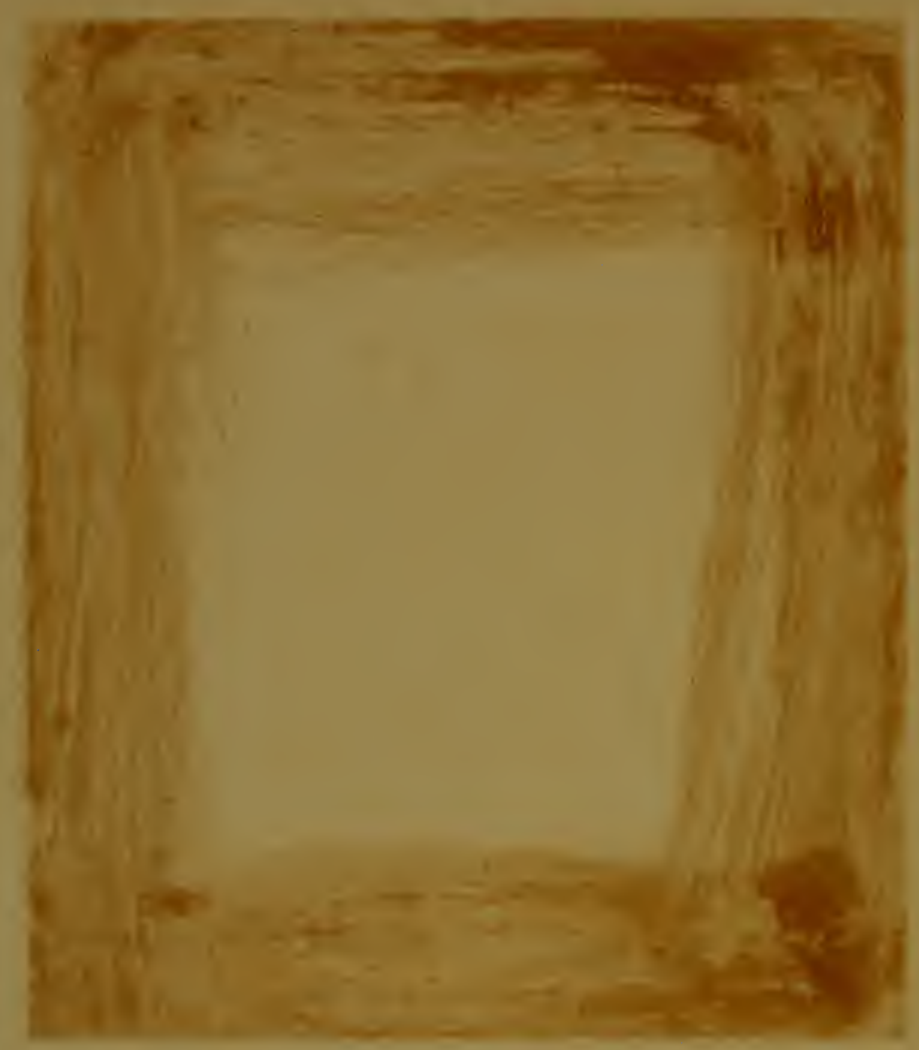






\section{WILD FLOWERS}

OF THE

NORTH AMERICAN MOUNTAINS 

$$
\text { , }
$$

, 


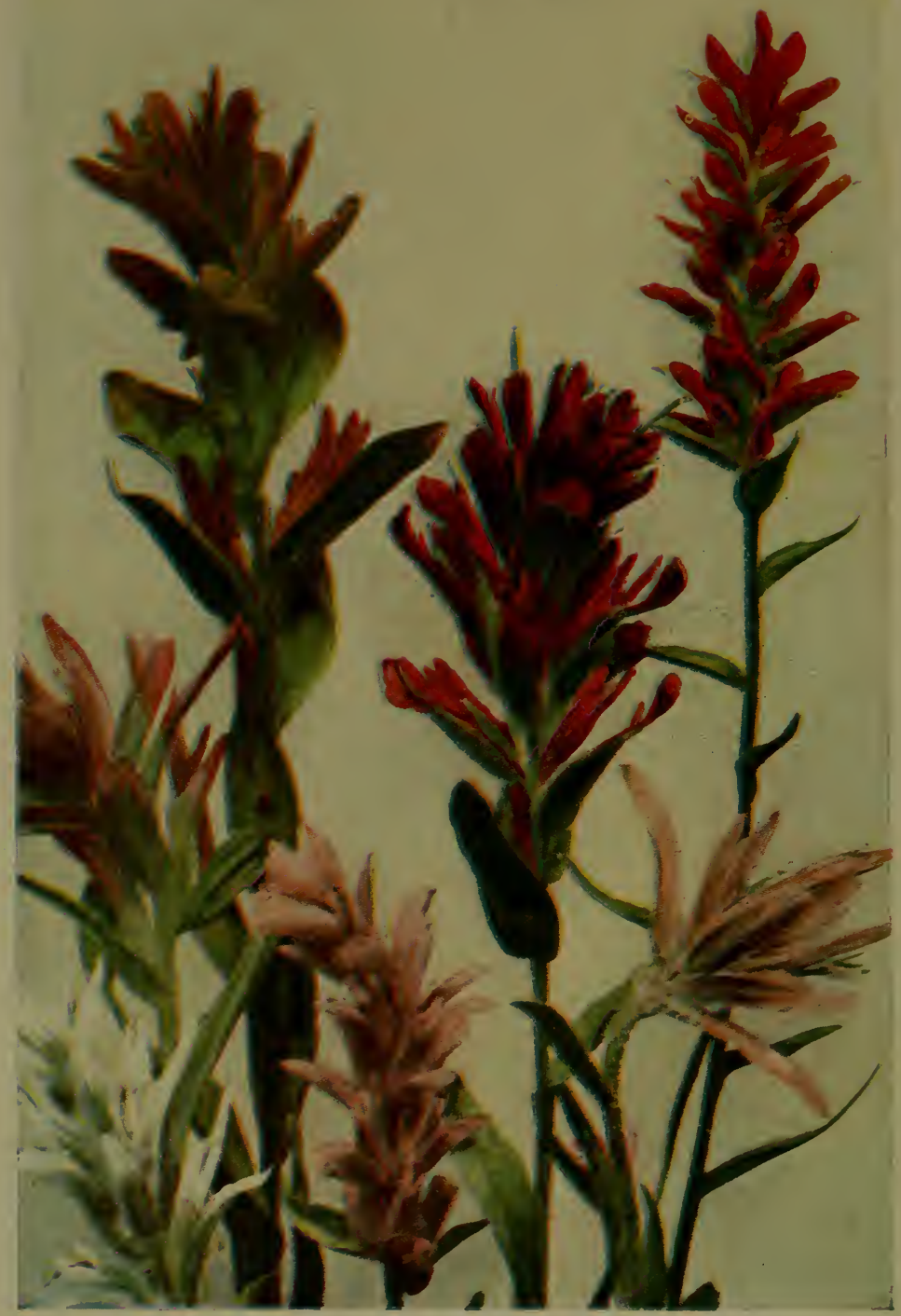

Red Indiax Paint Brush (Castilleja miniata) White Indian Paint Brush (Castilleja pallida)

Bradbury's Painted CuP (Castilleja angustifolia r'ar. Bradburii) 


\section{WILD FLOWERS OF THE \\ NORTH AMERICAN MOUNTAINS}

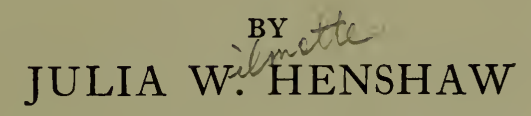

Fellow of the Royal Geographical Society.

Honorary Secretary of the Alpine Club of Canada.

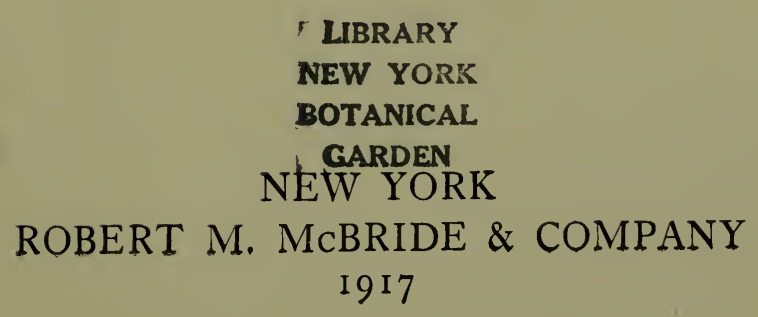


To

THEIR ROYAL HIGHNESSES

\section{THE DUKE AND DUCHESS OF CONNAUGHT}

this book is, by special permission,

yratefully dedicated in remembrance of days spent by

THEIR ROYAL HIGHNESSES

in the

ROCKY MOUNTAINS 



\section{PREFACE}

"When the book of life falls open at the page of spring," the snow-crowned mountains rule over an enchanting land of foliage, ferns and fungi, and the alpine meadows are ablaze with bright-hued flowers that grow luxuriantly beneath the broad blue tent of the sky.

Held close in the curved arms of the cliffs, the patches of verdure, starred with these wondrous-tinted blossoms, are a revelation to the traveller. From the mountains of the Yukon and Alaska to the hills of Nova Scotia and New England, in the Rockies, the Selkirks and the mountain ranges of Montana, Dakota, Washington, Oregon, California and other States, you will find that the same miracle has been wrought. On the lower levels white-flowered, scarlet-fruited shrubs mingle with the Wintergreens, Larkspurs, Violets and Columbines; flaming Indian Paint Brushes, Gentians, Queen-cups and purple Vetches cover many a slope; here a valley is carpeted with yellow Lilies, Gaillardias, Arnicas and Golden-rods - a glorious Fieldof-the-Cloth-of-Gold - and there some mossy plateau is gay with arctic-alpine Androsaces, Stonecrops, Everlastings and the trailing vines of the sweet-scented Northern Twinflowers; while in the crannies among the rocks Moss Campions, Romanzoffias and Saxifrages find a foothold; and down beside the ice-born streams grow beds of Wild Parsley, Water Willow Herb, Musk Flower, Lobelia and Ladies' Tresses. 
As the traveller climbs upward the scene changes among the barren rocks and frowning precipices, for here Nature stands revealed in majestic mood, and the lines of the landscape are sketched out rugged and severe. Then comes the sudden turn round the corner of some cliff, the o'ertopping of some steep stone ledge, and behold! before one, in a high alpine meadow, lies a garden such as kings might envy. But how describe the ecstasy of standing knee-deep in the fragrance of a thousand flowers? After crossing the bare bleak rocks it is like a triumphal entry into Paradise. Here are Pink Garlics, Harebells swaying in wild waywardness, Veronicas and Forget-me-nots looking up with wide-open eyes, Heathers red, rose and white, amethyst Asters, White Geraniums and Moccasin Flowers, all mingling with the shining green leaves and waxen petals of the Rhododendrons and the snowy chalices of the Globe-flowers and Anemones.

It matters not at what hour one goes to the mountains, whether in the amethyst dawn, when the golden gates of sunrise fall ajar and the first faint rustle of the leaves stirs the dreaming world to consciousness, dispersing mists and dew ; in the brilliant noontide, when life marches on with all her banners unfurled, and every plant is budding and blowing as the sap runs freely, and the sun's rays gild hill and vale: or in the amber evening when purple shadows steal with phantom feet from cliff to cliff, and down in the dusk of the forest dewdrops spangle leaf and bloom, as God lights the star-lamps of His high heaven and puts out the day.

Even when we listen to the rhythm of the rain all is beautiful, for the flowers that greeted the dawn with opal hearts wide-blown; that at noontide were found with 
"Each affluent petal outstretched and uncurled

To the glory and gladness and shine of the world."

and that at evening offered up sweetest fragrance in their chalice-cups, are given a new charm by the cool showers from above.

"The paths, the woods, the fields, the hills,

Are not a world to-day,

But just a place God made for us

In which to play."

So we may wander in search of the mountain wild flowers, following the trails which lead to the alpine meadows, and wrapt in the perfect peace of the hills remember that we are walking

"In the freedom of the garden wild"

with

"God of the open air."

As this book is intended for the use of the general public rather than for that of botanists, the flowers herein described are classified according to colour, and without special reference to their scientific relationship; for the first attribute of a plant which attracts the traveller's eye is invariably its colour, his first question usually being: "What is that red flower?"- or "blue flower," or "yellow flower," as the case may be. Of Order, Genus and Species he probably knows little, and therefore the descriptions given in this guide to mountain wild flowers are so simply and clearly worded, that any plants indexed may be readily located in one or other of the Colour Sections, together with its name and chief characteristics. The general Key at the beginning of the book will be of use to botanists.

The nomenclature followed throughout this work is 


\section{Preface}

strictly in accordance with the Vienna Rules, in so far as these have been worked out in Canada.

Plants will be found to vary greatly in size and appearance at various altitudes, becoming smaller and shorter as the summit of the mountain is approached, until at 7,000 or 8,ooo feet one will find the tiny leaves of the Moss Campion and Mountain Saxifrage growing flat upon the ground, their starry blossoms having no perceptible stalks, but being set close down into the moss-like plants. The Speedwell, Mouse-ear Chickweed, Alpine Azalea, Whitlow Grass, Eriogonum, Androsace, Saxifrage, Gentian and Stonecrop are all in evidence at very high elevations, growing in dwarfed alpine forms, and, together with the Heath, Heather and Anemone, are amongst the last flowers found at the edge of perpetual snow.

For his valuable assistance in preparing this book I offer my sincere thanks to Professor John Macoun, to whom I owe a debt of gratitude, beyond all repayment, for years of kindly help and encouragement. To Mr. James M. Macoun I also offer my hearty thanks for his expert advice given at all times with kindest courtesy.

To Sir Thomas G. Shaughnessy I am very deeply indebted for the interest he has always taken in my work among the mountains, which has led to the writing of this book.

\section{Julia IV. Henshaw.}

January, I9I 5 .

Vancouver,

British Columbia,

Canada. 
SidNEY,

British Columbia,

Canada,

January 3oth, I9I 5 .

Dear Mrs. Henshaw :

When you first told me of your intention to write a popular mountain flora, I assured you that such a work would not only serve a splendid purpose in attracting attention to the mountains, but that until the traveller had in his hands some such book that would enable him to identify the many flowers that grow there in profusion, he must feel lost among the unnamed beauties which would surround him. It was the one book needed.

That the work should have been done as you have done it, is more than I could have hoped. The beauty of the photographs, the correct grouping of the flowers, the concise and yet complete descriptions make it easy for even the visitor of a day to identify all the plants he is likely to see.

Your choice of English names, when such had not before been given to our alpine flowers, is excellent. They are themselves often sufficiently descriptive to enable one to idntify the species.

I am glad to note, too, that the generic names you have used are strictly in accordance with the Vienna Rules, as are also the specific names so far as these have been worked out in Canada.

Yours sincerely,

John Macoun,

Dominion Naturalist. 



\section{CONTENTS}

PAǴE

Letter from Professor John Macoun M. A., F. L. S., F. R.

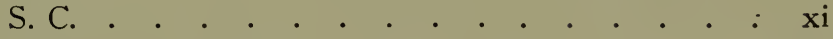

List of Uncoloured Plates . . . . . . . . . . . . . . . $\quad$ xv List of Coloured Plates . . . . . . . . . . . . . . xvii General Key to the Families . . . . . . . . . . . . . . I

SECTION

I. Ferns and Fern Allies . . . . . . . . . . . . 47

II. Trees . . . . . . . . . . . . . . . . . . . 6I

III. Reeds, Grasses, Sedges and Rushes . . . . . . 8I

IV. White to Green and Brown Flowers . . . . . 9i

V. Pink to Red Flowers . . . . . . . . . . 205

VI. Blue to Purple Flowers . . . . . . . . . 257

VII. Yellow to Orange Flowers . . . . . . . . . 305

Glossary . . . . . . . . . . . . . . . 363

Index to Scientific Names . . . . . . . . . . . . . 369

Index to English Names . . . . . . . . . . . 377 



\section{LIST OF UNCOLOURED PLATES}

PLATE

I. Oak Fern . . . . Phegopteris Dryopteris . . . 48

II. Spinulose Shield Fern Aspidium spinulosum var. dilatatum . . . . . . . 54

III. Lodge Pole Pine . . Pinus contorta var. Murrayana 64

IV. Engelmann's Spruce . Picea Engelmanni . . . . 66

V. Balsam Fir . . . Abies lasiocarpa . . . . . 68

VI. Mountain Hemlock . Tsuga Mertensiana . . . . 70

VII. Red Cedar . . . . Thuya plicata . . . . . . 72

VIII. Hare's Tail . . . Eriophorum callitrix . . . 84

IX. Green Lily . . . . Zygadenus elegans . . . . 93

$\mathrm{X}$. Indian Hellebore . . Veratrum viride . . . . . 95

XI. Queen-Cup . . . . Clintonia uniflora . . . . 97

XII. False Solomon's Seal . Smilacina amplexicaulis . . 99

XIII. Star-flowered Solomon's Seal . . . Smilacina stellata . . . . 100

XIV. White Twisted-stalk . Streptopus amplexifolius . . I03

$\mathrm{XV}$. White Moccasin

Flower . . . Cypripedium passerinum . . I04

XVI. White Rein Orchis . Habenaria dilatata . . . . 107

XVII. Northern Rein Orchis Habenaria obtusata . . . . 108

XVIII. Hooded Ladies'Tresses Spiranthes Romanzoffiana . . III

XIX. Early Coral Root . . Corallorhiza trifida . . . . II5

XX. Alpine Bistort . . . Polygonum viviparum . . . II9 Glutinous Asphodel . Tofieldia glutinosa . . . . I I9

XXI. Wind Flower . . . Anemone multifida . . . . I27

XXII. White Globe Flower . Trollius laxus var. albiflorus . I30

XXIII. Red Baneberry . . . Actaa rubra . . . . . . 132

XXIV. Alpine Saxifrage . . Saxifraga nivalis . . . . I4I

XXV. Nancy-over-the-ground Tiarella unifoliata . . . . I43

XXVI. Oval-leaved Alum Root Heuchera ovalifolia . . . . I45

XXVII. Tellima . . . . . Tellima grandiflora . . . . I47

XXVIII. Birch-leaved Spiræa . Spirca lucida . . . . . I5I

XXIX. Goat's Beard . . . Aruncus syliester . . . . I53

XXX. Common Serviceberry Amelanchier florida . . . . I55

XXXI. Capberry . . . . Rubus parviflorus . . . . I57

XXXII. Wood Nymph . . . Dryas octopetala . . . . I59 


\section{LIST OF UNCOLOURED PLATES}

PLATE

XXXIII Lentil Vetch

XXXIV. Canada Violet . . . Viola canadensis . . . . . 165

XXXV. Fern-leaved Lovage . Ligusticum apiifolium . . . 169

XXXVI. Cow Parsnip . . . Heracleum lanatum . . . . I7I

XXXVII. Bunchberry . . . . Cornus canadensis . . . . I73

XXXVIII. Indian Pipe . . . . Monopropa uniflora . . . . I77

XXXIX. Mountain Rhododen-

dron . . . . Rhododendron albiflorum . . I8I

XL. White Heath . . . Cassiope Mertensiana . . . 184

XLI. Mist Maidens . . . Romanzoffia sitchensis . . . I88

XLII. Contorted Lousewort . Pedicularis contorta . . . . . I90

XLIII. Pink Garlic . . . . Allium cernuum . . . . . 206

XLIV. Fly-spotted Orchis . Orchis rotundifolia . . . . 208

XLV. Moss Campion . . . Silene acaulis . . . . . 212

XLVI. Red Wintergreen . . Pyrola asarifolia var. incarnata 227 Green-flowered Wintergreen . . . . Pyrola chlorantha . . . 227

XLVII. Red Mountain Heather Bryanthus empetriformis . . $23 \mathrm{I}$

XLVIII. Red Bearberry . . . Arctostaphylos Uva-ursi . . 233

XLIX. Red Monkey Flower . Mimulus Lewisii . . . . . $24 \mathrm{I}$

L. Rough Fleabane . . Erigeron glabellus . . . . $25 \mathrm{I}$

LI. Pink Everlasting . . Antennaria rosea . . . . . 252

LII. Ascending Milk Vetch Astragalus adsurgens . . . 265

LIII. Alpine Milk Vetch . Astragalus alpinus . . . . 266

LIV. Alpine Oxytrope . . Oxytropis viscida . . . . 268

LV. Four-parted Gentian . Gentiana propinqua . . . . 277

LVI. Harebell . . . . Campanula rotundifolia . . . 293

LVII. Brook Lobelia . . . Lobelia Kalmii . . . . . 295

LVIII. Western Skunk Cabbage . . . . Lysichiton kamtschatcense . . 306

LIX. Mountain Lily . . . Lilium montanum . . . . 308

LX. Bladder-pod . . . Physaria didymocarpa . . . 321

LXI. Silverberry . . . . Elcagnus argentea . . . . 335

LXII. Bush Fly Honeysuckle Lonicera utahensis . . . . 345

LXIII. Field Golden-rod . . Solidago decumbens . . . 349

LXIV. Alpine Arnica . . . Arnica alpina . . . . . 355 


\section{LIST OF COLOURED PLATES}

Red Indian Paint Brush . . . Castilleja miniata . FrontisPIeCE White Indian Paint Brush . . Castilleja pallida.

Bradbery's Painted Cup . . . . Castilleja angustifolia car. Bradburii.

FACING

PAGE

Tall Eriogonum . . . . . . Eriogonum umbellatum var.

Chalice Cup Anemone occidentalis . . . I I6

Purple Hedysarum . . . . . . Hedysarum boreale . . . . 160

White Hedysarum . . . . . Hedysarum sulphurescens . . 160

Woolly Labrador Tea . . . . . Ledum granlandicum . . . 178

Wild Heliotrope . . . . . . Valeriana sitchensis . . . . 194

Calypso . . . . . . . . . Calypso bulbosa . . . . . 210

Western Columbine . . . . . Aquilegia formosa . . . .2I4

Water Willow-herb . . . . . Epilobium latifolium . . . 224

Northern Twin Flower . . . . Linnca borealis var. americana 248

Wild Flax . . . . . . . . Linum Lewisii . . . . . 272

Mountain Phacelia . . . . . . Phacelia scricea . . . . . . 280

Yellow Adder's Tongue . . . Erythronium grandift ri:m . . उIO

Drummond's Dryas . . . . . Dryas Drummondii . . . . 332

Brown-eyed Susan . . . . . . Gaillardia aristata . . . . 352

Hairy Hawkweed . . . . . . Hieracium Scouleri . . . 360 



\section{WILD FLOWERS}

OF THE

NORTH AMERICAN MOUNTAINS 



\title{
GENERAL KEY TO THE FAMILIES
}

\section{DIVISION I. PTERIDOPHYTA.}

\author{
(Ferns and Fern Allies)
}

Fern-like, rush-like, moss-like or aquatic plants, without true flowers. Reproduction by spores.

\section{ORDER I. FILICALES}

\section{POLYPODIACEÆ. FERN FAMILY}

Leafy plants with creeping rhizomes. Spores borne in sporangia collected in dots, lines or clusters on the backs or margins of the fronds or their divisions.

I. Phegopteris. (Presl.) Fée.

I. P. polypodioides. Fée. Long Beech Fern.

2. P. alpestris. (Hoppe.) Mett. Tufted Beech Fern.

3. P. Dryopteris. (L.) Fée. Oak Fern.

II. Adiantum. (Tourn.) L.

I. A. pedatum. L. Maidenhair.

III. Pteris. L.

I. P. aquilina var. lanuginosa. Bong. Common Bracken.

IV. Cheilanthes. Sw.

I. C. Féei. Moore. Slender Lip Fern.

V. Pellex. Link.

I. P. atropurpurea. (L.) Link. Purple Cliff Brake.

Vi. Cryptogramma. R. Br.

I. C. acrostichoides. R. Br. Nootka Rock Brake.

2. C. Stelleri. (Gmel.) Prantl. Slender Rock Brake.

VII. Asplenium. L.

I. A. viride. Huds. Green Spleenwort.

2. A. cyclosorum. Rupr. Large Lady Fern.

VIII. Polystichum. Roth.

I. P. Lonchitis. (L.) Roth. Holly Fern. 
IX. Aspidium. Sw.

I. A. Filix-mas. (L.) Sw. Male Shield Fern.

2. A. spinulosum var. dilatatum. (Hoffm.) Hook. Spinulose Shicld Fern.

3. A. Oreopteris. Sw. Scaly Shield Fern.

X. Cystopteris. Bernh.

I. C. fragilis. (L.) Bernh. Brittle Fern.

2. C. montana. (Lam.) Bernh. Mountain Bladder Fern.

\section{OPHIOGLOSSACEE. ADDER'S TONGUE FAMILY}

Leafy, fleshy plants; leaves simple or branched, fern-like, erect in vernation, the bud placed either inside the base of the old stalk or beside it; sporangia borne in spikes or panicles formed from the main tissue of the fruiting branches.

I. Botrychium. Sw.

I. B. Lunaria. (L.) Sw. Moonwort.

2. B. simplex. E. Small Moonzvort.

3. B. virginianum. (L.) Sw. Rattlesnake Fern.

4. B. lanceolatum. (Gmel.) Angstroem. Slender Moonwort.

\section{ORDER II. EQUISETALES}

\section{EQUISETACEÆE. HORSETAIL FAMILY}

Rush-like green plants with jointed usually hollow stems from running rootstocks; the branches verticillate, with toothed sheaths at the nodes, and when fertile bearing the sporangia beneath the scales of the terminal cone-shaped spikes.

I. Equisetum. (Tourn.) L.

I. E. arvense. L. Field Horsetail.

2. E. pratense. Ehrh. Thicket Horsetail.

3. E. sylvaticum. L. Wood Horsetail.

4. E. scirpoides. Michx. Rush Pipes.

5. E. fluviatile. L. Swamp Horsetail.

6. E. variegatum. Schleich. Variegated Horsetail.

7. E. hyemale. L. Scouring Rush. . 


\section{ORDER III. LYCOPODIALES}

\section{LYCOPODIACEA. CLUB MOSS FAMILY}

Low-growing moss-like plants with branching, trailing or erect stems; leaves small, lanceolate, persistent, entire; sporangia solitary in the axils of the leaves, or on their upper surface. Isoporous.

I. Lycopodium. L.

I. L. annotinum. L. Stiff Club Moss.

2. L. clavatum. L. Creeping Club Moss.

3. L. Selago. L. Fir Club Moss.

4. L. alpinum. L. Alpine Club Moss.

5. L. sitchense. Rupr. Arctic Club Moss.

6. L. complanatum. L. Trailing Christmas Green.

\section{SELAGINELLACE E. SELAGINELLA FAMILY}

Small, leafy terrestial plants with branching stems; leaves scalelike, many-ranked, uniform ; sporangia one-celled, solitary, axillary or borne at the base of the upper surface of the leaf. Heterosporous.

I. Selaginella. Beauv.

I. S. selaginoides. (L.) Link. Small Selaginella.

2. S. rupestris. (L.) Spring. Rock Selaginella.

\section{DIVISION II. SPERMATOPHYTA}

(Seed-plants, Phanerogmia, or Flowering Plants)

Flowers with stamens, or pistils, or both. Normal reproduction by seeds containing an embryo or minute plant.

\section{SUBDIVISION I. GYMNOSPERMÆ}

ORDER IV. CONIFERALES

\section{TAXACEÆ. YEW FAMILY}

Trees or shrubs; sparingly resinous; leaves evergreen or deciduous, linear, spreading in two ranks; flowers diœcious, or rarely 
monœcious, axillary, solitary; fruit a bony-coated seed, or rarely a cone.

\section{Taxus. (Tourn.) L.}

I. T. brevifolia. Nutt. Western Yew.

\section{PINACEÆ. PINE FAMILY}

Trees or shrubs, mostly evergreen; leaves needle-shaped, entire; flowers monœcious or rarely diœcious, borne in the form of scaly catkins of which the fertile ones become berry-like or cones; juice resinous.

I. Pinus. (Tourn.) L.

I. P. albicaulis. Engelm. White-bark Pine.

2. P. monticola. Dougl. Mountain Pine.

3. P. ponderosa. Dougl. Bull Pine.

4. P. contorta var. Murrayana. Engelm. Lodge Pole Pine.

II. Larix. (Tourn.) Adans.

I. Lyallii. Parl. Lyall's Larch.

III. Picea. Link.

I. P. canadensis. (Mill.) BSP. White Spruce.

2. P. Engelmanni. Parry. Engelmann's Spruce.

IV. Abies. (Tourn.) Hill.

I. A. lasiocarpa. (Hook.) Nutt. Balsam Fir.

V. Tsuga. (Endl.) Carr.

I. T. heterophylla. (Raf.) Sarg. Western Hemlock.

2. T. Mertensiana. (Bong.) Carr. Mountain Hemlock.

VI. Pseudotsuga. Carr.

I. P. taxifolia. Britton. Douglas Fir.

VII. Thuya. L.
I. T. plicata. Donn. Red Cedar.

VIII. Juniperus. (Tourn.) L.

I. J. scopulorum. Sarg. Rocky Mountain Juniper.

2. J. horizontalis. Moench. Crecping Juniper.

3. J. communis var. montana. Ait. Alpine Juniper. 


\section{SUBDIVISION II. ANGIOSPERMÆ}

\section{Class I. Monocotyledonex}

\section{ORDER V. PANDANALES}

\section{TYPHACEÆ. CAT-TAIL FAMILY}

Aquatic or marsh herbs with creeping rootstocks; leaves nerved, linear, sessile; flowers monœcious, numerous on a spadix destitute of proper floral envelope; fruit nut-like, usually splitting on one side.

I. Typha. (Tourn.) L.

I. T. latifolia. L. Broad-leaved Cat-tail.

\section{SPARGANIACE\&E. BUR-REED FAMILY}

Marsh or aquatic herbs with erect or floating stems; leaves alternate, linear, sessile, two-ranked; flowers monœcious with inglobular, sessile or pedunculate heads; fruit nut-like, obovoid or spindle-shaped.

I. Sparganium. (Tourn.) L.

I. S. simplex. Huds. Simple-stemmed Bur-reed.

\section{ORDER VI. NAJADALES}

\section{NAJADACE正. PONDWEED FAMILY}

Marsh or immersed aquatic herbs with slender, jointed, leafy stems; leaves flat or filiform, sheathing at the base; flowers perfect or unisexual with a perianth of four or six distinct valvate or tubular segments; fruit an indehiscent berry.

I. Potamogeton. (Tourn.) L.

I. P. Richardsonii. (Benn.) Rydb. Richardson's Pondweed.

2. P. filiformis. Pers. Filiform Pondweed. 


\section{JUNCAGINACEAE. ARROW GRASS FAMILY}

Herbs with creeping rhizomes and hollow stems, mostly perennial; leaves alternate, sheathing, channelled or terete; flowers perfect, small, spicate, or racemose with six-lobed perianth; fruit capsular or follicular.

I. Triglochin. L.

I. T. palustris. L. Marsh Arrow Grass.

\section{ORDER VII. GRAMINALES}

\section{GRAMINEÆ. GRASS FAMILY}

Herbs with culms closed at the nodes; leaves paralleled-veined, consisting of a sheath and a blade; flowers perfect, very small, arranged in spikelets; fruit a caryopsis with starchy endosperm and a small embryo at the base.

\section{SUBFAMILY POACOIDEÆ}

TRIBE AGROSTIDE

I. Phleum. $\mathrm{L}$.

I. P. alpinum. L. Alpine Timothy.

II. Calamagrostis. Adans.

I. C. canadensis. (Michx.) Beauv. Blue-joint Grass.

TRIBE FESTUCEÆ

III. PoA. L.

I. P. alpina. L. Alpine Spear Grass.

IV. Festuca. L.

I. F. ovina. L. Sheep's Fescue Grass.

V. Bromus. L.

I. B. Richardsonii var. pallidus. (Hook.) Shear. Fringed Brome Grass.

TRIBE HORDEÆ

VI. Hordeum. (Tourn.) L.

I. H. jubatum. L. Squirrel-tail Grass. 


\section{CYPERACEÆ. SEDGE FAMILY}

Grass-like or rush-like herbs with fibrous roots, mostly solid culms and closed sheaths; flowers spiked in the axils of the imbricated bracts, destitute of any perianth; fruit an achene.

TRIBE SCIRPEÆ

I. Eriophorum. L.

I. E. callitrix. Cham. Hare's Tail.

2. E. angustifolium. Roth. Cotton Grass.

TRIBE CARICE压

II. Kobresia. Willd.

I. K. bipartita. (All.) Britton. Arctic Kobresia.

2. K. Bellardi. (All.) C. Koch. Arctic Elyna.

III. Carex. (Ruppius.) L.

I. C. festiva. Dewey Sill. Tussock Sedge.

2. C. pyrenaica. Wahl. Dwarf Sedge.

3. C. Mertensii. P. Bong. Merten's Sedge.

4. C. nigricans. C. A. Meyer. Black Sedge.

5. C. rupestris. All. Rock Sedge.

\section{ORDER VIII. ARALES}

\section{ARACE AE. ARUM FAMILY}

Perennial herbs with pungent juice and tuberous rootstocks; leaves large, veiny, simple or compound, abundant; flowers crowded on a spadix which is usually surrounded by a spathe; fruit usually a berry.

I. Lysichiton. Schott.

I. L. kamtschatcense. Schott. Western Skunk Cabbage.

\section{ORDER IX. LILIALES \\ XV. JUNCACEE. RUSH FAMILY}

Rush-like or grass-like herbs; leaves alternate, sheathing, channelled or terete; flowers small, liliaceous in structurê, but sedge- 
like in aspect and texture, regular, hypogynous, persistent; fruit seeds anatropous with a tiny embryo enclosed within the base of fleshy albumen.

I. Juncus. (Tourn.) L.

I. J. Mertensianus. Bong. Merten's Bog Rush.

2. J. triglumis. L. Three-flowered Bog Rush.

3. J. Drummondii. E. Meyer. Drummond's Bog Rush.

4. J. Parryi. Engelm. Parry's Bog Rush.

II. Luzula. DC.

I. L. parviflora. (Ehrh.) Desv. Small-flowered Wood Rush.

2. L. spicata. (L.) DC. Spiked Wood Rush.

\section{LILIACEA. LILY FAMILY}

Herbs or rarely woody plants; leaves at the base, or in whorls, or pairs on the stems; flowers borne singly, or in umbels, or racemes on a usually naked stem; fruit a seeded pod or berry, seeds various, winged or wingless.

TRIBE VERATREÆ

I. Tofieldia. Huds.

I. T. glutinosa. (Michx.) Pers. Glutinous Asphodel.

2. T. palustris. Huds. Scottish Asphodel.

3. T. occidentalis. Watson Proc. Western Asphodel.

II. Stenanthium. (Gray.) Kunth.

I. S. occidentale. Gray. Bronze Bells.

III. Zygadenus. Michx.

I. Z. elegans. Pursh Fl. Green Lily.

2. Z. venenosus. Wats. Poisonous Green Lily.

IV. Veratrum. (Tourn.) L.

I. V. viride. Ait. Indian Hellebore.

TRIBE ALLIEÆ

V. Allium. (Tourn.) L.

I. A. cernuum. Roth. Pink Garlic.

2. A. Schœnoprasum var. sibiricum. (L.) Hartm. Purple Garlic. 
TRIBE LILIEÆ

VI. LILIUM. (Tourn.) L.

I. L. montanum. A. Nels. Mountain Lily.

2. L. columbianum. Hansen. Western Lily.

VII. Fritillaria. L.

I. F. pudica. Yellow Fritillary.

VIII. Erythronium. L.

I. E. grandiflorum. Pursh. Yellow Adder's Tongue.

2. E. grandiflorum var. parviflorum. Watson. Small Yellow Adder's Tongue.

3. E. montanum. Watson. Mountain Adder's Tongue.

IX. Calochortus. Pursh.

I. C. macrocarpus. Dougl. Green-banded Mariposa.

2. C. Lyallii. Baker. Pale Mariposa.

TRIBE POLYGONATEÆ

X. Clintonia. Raf.

I. C. uniflora. Kunth. Queen-cup.

XI. Smilacina. Desf.

I. S. amplexicaulis. Nutt. False Solomon's Seal.

2. S. stellata. Desf. Star-flowered Solomon's Seal.

XII. Disporum. Salisb.

I. D. trachycarpum. B. and H. Fairy Bells.

2. D. oreganum. B. and H. Woolly Disporum.

XiII. Streptopus. Michx.

I. S. amplexifolius. (L.) DC. White Trwisted-stalk.

XIV. KRUhSEA.

2. S. roseus. Michx. Pink Twisted-stalk.

I. K. streptopoides. (Ledeb.) Kearney. Short-stemmed Truisted-stalk.

\section{IRIDACEE. IRIS FAMILY}

Herbs with rootstocks, tubers or corms; leaves equitant, sheathing, linear, two-ranked; flowers regular or irregular, perfect, from a spathe of two or more leaves or bracts; fruit three-celled, manyseeded. 
I. Sisyrinchium. L.

I. S. angustifolium. Mill. Stiff Blue-eyed Grass.

2. S. idahœnse. Bicknell. Twisted Blue-eyed Grass.

3. S. septentrionale. Bicknell. Small Blue-eyed Grass.

4. S. californicum. Yellow Blue-eyed Grass.

\section{ORDER X. ORCHIDALES}

\section{ORCHIDACE更. ORCHIS FAMILY}

Perennial herbs, often with corms or tuberoid roots, sometimes rootless saprophytes; leaves paralleled-nerved, solitary or several, alternate; flowers solitary, in racemes or spikes, perfect, zygomorphic, gynandrous with the perianth adnate to the one-celled ovary, one division termed the lip differing from the rest in shape, and sometimes prolonged into a spur at the base; fruit a onecelled, three-valved capsule.

\section{TRIBE CYPRIPEDIEÆ}

I. Cypripedium. L.

I. C. pubescens. (Willd.) Knight. Large Yellow Lady's Slipper.

2. C. parviflorum. Salisb. Small Yellow Lady's Slipper.

3. C. passerinum. Richards. White Moccasin Flower.

TRIBE OPHRYDE $Æ$

II. Orchis. (Tourn.) L.

I. O. rotundifolia. Banks. Fly-spotted Orchis.

III. Habenaria. Willd.

I. H. dilatata. (Pursh.) Gray. White Rein Orchis.

2. H. bracteata. (Willd.) R. Br. Long-bracted Rein Orchis.

3. H. obtusata. (Pursh.) Richards. Northern Rein Orchis.

4. H. hyperborea. (L.) R. Br. Leafy Rein Orchis.

5. H. gracilis. 'Wats. Graceful Rein Orchis.

6. H. orbiculata. (Pursh.) Torr. Round-leaved Rein Orchis. 
TRIBE NEOTTIE压

IV. Spiranthes. Richards.

I. S. Romanzoffiana. Cham. Hooded Ladies' Tresses.

V. Epipactis. (Haller.) Boehm.

I. E. decipiens. (Hook.) Ames. Stout Rattlesnake Plantain.

2. E. repens. (L.) Crantz. Small Rattlesnake Plantain.

VI. Listera. R. Br.

I. L. cordata. (L.) R. Br. Heart-leaved Twayblade.

2. L. convallarioides. (Sw.) Torr. Broad-lipped Twayblade.

TRIBE EPIDENDREÆ

ViI. Corallorhiza. (Haller.) R. Br.

I. C. trifida. Chatelain. Early Coral Root.

2. C. maculata. Raf. Spotted Coral Root.

3. C. striata. Lindl. Striped Coral Root.

4. C. Mertensiana. Bong. Spurred Coral Root.

VIII. Calypso. Salisb.

I. C. bulbosa. (L.) Oakes. Calypso.

Class II. Dicotyledone

Subclass I. Archichlamydea

ORDER XI. SALICALES

\section{SALICACEE. WILLOW FAMILY}

Trees or shrubs, the wood soft and light, bark bitter; leaves alternate undivided; flowers of both kinds in catkins, one to each bract, without perianth; fruit a pod bearing numerous seeds furnished with long silky down.

I. Salix. (Tourn.) L.

I. S. candida. Flugge. Hoary Willow.

2. S. Barclayi. Anders. Barclay's Willow.

3. S. Barrattiana. Barratt's Willow. 
4. S. Bebbiana. Sargent. Brown Willow.

5. S. nivalis. Hook. Alpine Willow.

6. S. petrophila. Rydb. Dwarf Willow.

7. S. vestita. Pursh. Hairy Willow.

8. S. sitchensis. Sanson. Sitka Willow.

9. S. arctica. Pall. Arctic Willow.

\section{Populus. (Tourn.) L.}

I. P. tremuloides. Michx. Aspen Poplar.

2. P. balsamifera. L. Balm of Gilead.

3. P. trichocarpa. Hook. Western Balsam Poplar.

4. P. acuminata. Rydb. Cottonwood.

\section{ORDER XII. FAGALES}

\section{BETULACE㭱. BIRCH FAMILY}

Trees or shrubs; leaves alternate, simple, straight-veined; flowers small, appearing with or before the leaves, the sterile in catkins, the fertile clustered, spiked, or in scaly catkins; fruit a nut lenticular, surrounded by a wing.

I. Betula. (Tourn.) L.

I. B. fontinalis. Sarg. Black Birch.

2. B. alba. (L.) var. papyrifera. (Marsh.) Spach. Paper Birch.

3. B. glandulosa. Michx. Dwarf Birch.

II. Alnus. (Tourn.) Hill.

I. A. sinuata. (Regel.) Rydb. Mountain Alder.

2. A. sitchensis. Nutt. Speckled Alder.

\section{ORDER XIII. URTICALES}

\section{URTICACEÆ. NETTLE FAMILY}

Herbs rarely shrubs, with watery juice, belonging to a large family; leaves alternate or opposite, frequently stipulate, simple; flowers a small, diœcious, monœcius or polygamous, variously clustered; fruit an achene.

I. Urtica. (Tourn.) L.

I. U. Lyallii. Wats. Common Nettle. 


\section{ORDER XIV. SANTALALES}

\section{SANTALACEE. SANDALWOOD FAMILY}

Herbs, shrubs or trees; leaves entire, without stipules; flowers solitary or clustered, axillary or terminal, calyx valvate in the bud, its tube adnate to the base of the ovary; fruit a drupe or nut, the seed solitary, destitute of any proper seed-coat.

I. Comandra. Nutt.

I. C. pallida. A. DC. White Comandra.

2. C. iivida. Richards. Swamp Comandra.

3. C. Richardsiana. Fernald. Green Comandra.

\section{LORANTHACEÆ. MISTLETOE FAMILY}

Chiefly shrubby plants parasitic on trees; leaves coriaceous, opposite regular, greenish, yellowish or olive-brown; flowers in axillary or terminal clusters or solitary; fruit a berry with glutinous pulp.

I. Arceuthobium. Bieb.

I. A. americanum. Nutt. Witch's Broom.

\section{ORDER XV. POLYGONALES}

\section{POLYGONACEE. BUCKWHEAT FAMILY}

Herbs, shrubs or trees with stipules in the form of sheaths above the swollen joints of the stem; leaves simple, entire; flowers mostly perfect, with a more or less persistent calyx; fruit an achene.

I. Eriogonum. Michx.

I. E. umbellatum. var. majus. Benth. Tall Eriogonum.

2. E. ovalifolium. Nutt. Silvery Eriogonum.

3. E. androsaceum. Benth. Dwarf Eriogonum.

II. Oxyria. Hill.

I. O. digyna. (L.) Hill. Mountain Sorrel.

III. Rumex. L.

I. R. salicifolius. Willow-leaved Dock.

2. R. Acetosa. L. Common Sorrel. (Introduced.)

3. R. Acetosella. L. Field Sorrel. (Introduced.) 
IV. Polygonum. (Tourn.) L.

I. P. viviparum. L. Alpine Bistort.

2. P. bistortoides. Pursh. Heart-lcaved Bistort.

3. P. Muhlenbergii. (Meisn.) Wats. Szvamp Persicaria.

\section{ORDER XVI. CHENOPODIALES}

\section{CHENOPODIACEÆ. GOOSEFOOT FAMILY}

Herbs or shrubs of homely aspect; leaves more or less succulent, alternate, without stipules; flowers minute, with the free calyx imbricated in the bud, usually in axillary and terminal panicles or racemes; fruit an achene or utricle.

I. Chenopodium. (Tourn.) L.

I. C. album. L. Lamb's Quarters. (Introduced.)

2. C. capitatum. (L.) Asch. Strazuberry Blite.

\section{ORDER XVII. CARYOPHYLLALES}

\section{CARYOPHYLLACEA. PINK FAMILY}

Herbs with bland and inert juice, the stems usually swollen at the nodes; leaves opposite, entire, often united at the base; flowers symmetrical, with or without petals; fruit a capsule opening by valves at the summit.

I. Arenaria. L.

I. A. lateriflora. L. Blunt-leaved Sandwort.

2. A. capillaris var. nardifolia. (Ledeb.) Regel. Narrozu-leaved Sandwort.

3. A. verna var. propinqua. (Richards.) Fernald. Vcrnal Sandwort.

4. A. sajanensis. Willd. One-flowered Sandwort.

II. Stellaria. L.

I. S. longipes. Goldie. Long-stalked Stitchwort.

2. S. borealis. Bigel. Northern Stitchwort.

iII. Cerastium. L.

I. C. arvense. L. Ficld Mouse-ear Chickweed.

2. C. alpinum. L. Alpine Mouse-ear Chickweed. 
IV. Lychnis. (Tourn.) L.

I. L. apetala. L. Nodding Pink.

2. L. Drummondii. (Hook.) Wats. Drummond's Pink.

V. Silene. L.

I. S. Macounii. Wats. White Campion.

2. S. Lyallii. Wats. Lyall's Catchfly.

3. S. acaulis. L. Moss Campion.

\section{PORTULACACERE. PURSLANE FAMILY}

Insipid herbs; leaves entire, succulent, simple; flowers axillary or terminal, essentially regular but unsymmetrical, sepals fewer than the petals; fruit a capsule.

I. Lewisia. Pursh.

I. L. rediviva. Pursh. Bitter-root.

II. Oreobroma. Howell. Eryth.

I. O. cotyledon. Howell. Striped Oreobroma.

iII. Claytonia. (Gronov.) L.

I. C. lanceolata. Pursh. Lance-leaved Spring Beauty.

2. C. megarrhiza. (Gray.) Parry. Alpine Spring Beauty.

3. C. parvifolia. Dougl. Small-leaved Spring Beauty.

\section{ORDER XVIII. RANUNCULALES}

\section{NYMPHÆACEÆ. WATER LILY FAMILY}

Aquatic perennial herbs with horizontal rootstocks; leaves peltate or deeply cordate, involute from both margins in the bud, floating or immersed; flowers perfect, axillary, solitary on long peduncles; fruit baccate, with a firm rind.

I. Nyмphжа. (Tourn.) L.

I. N. polysepala. (Engelm.) Greene. Yellow Pond Lily.

\section{RANUNCULACEE. CROWFOOT FAMILY}

Herbs or sometimes woody plants with a colourless usually acrid juice; leaves often dissected, their stalks dilated at the base, some- 


\section{i6 General Key to the Families}

times with stipule-like appendages, alternate or rarely opposite; flowers polypetalous or apetalous with the calyx often coloured like a corolla, hypogynous; fruit achenes or follicles or baccate.

\section{TRIBE ANEMONEÆ}

I. Ranunculus. (Tourn.) L.

I. R. acris. L. Meadow Buttercup. (Introduced.)

2. R. Macounii. Britton. Macoun's Buttercup.

3. R. Eschscholtzii. Schlect. Snow Buttercup.

4. R. Cymbalaria. Pursh. Creeping Crozufoot.

5. R. aquatilis. (L.) var. capillaceus. DC. Water Crozufoot.

6. R. reptans. (L.) Mey. Creeping Spearwort.

7. R. repens. L. Ycllow Crowfoot. (Introduced.)

8. R. pygmæus. Wahl. Pigmy Buttercup.

II. Thalictrum. (Tourn.) L.

I. T. occidentale. Gray. Western Mcadow Rue.

2. T. megacarpum. Torr. Veiny Meadow Rue.

III. Anemone. (Tourn.) L.

I. A. occidentalis. Wats. Chalice Cup.

2. A. multifida. Poir. Wind Flower.

3. A. Drummondii. Wats. Alpine Anemone.

4. A. parviflora. Michx. Few-flowered Anemone.

5. A. patens var. Wolfgangiana. (Bess.) Koch. Pasque Flower.

TRIBE CLEMATIDE $Æ$

IV. Clematis. L.

I. C. ligusticifolia. Nutt. White Clematis.

2. C. columbiana. (Nutt.) T. and G. Purple Clematis.

TRIBE HELEBOREÆ

V. Caltha. (Rupp.) L.

I. C. leptosepala. DC. Alpine Marsh-marigold.

2. C. palustris. L. Marsh-marigold.

VI. Trollius. L.

I. T. laxus var. albiflorus, Salisb. White Globe Flower; 
VII. Aquilegia. (Tourn.) L.

I. A. formosa. Fisch. Western Columbine.

2. A. brevistyla. Hook. Blue Columbine.

3. A. flavescens. Wats. Yellow Columbine.

ViII. Delphinium. (Tourn.) L.

I. D. Brownii. Rydb. Mountain Larkspur.

2. D. Menziesii. DC. Bluc Larkspur.

3. D. bicolor. Nutt. Blue-veined Larkspur.

IX. AстÆA. L.

I. A. rubra. (Ait.) Willd. Red Baneberry.

2. A. rubra forma neglecta. (Gillman.) Robinson. White Baneberry.

\section{BERBERIDACEÆ. BARBERRY FAMILY}

Shrubs or herbs; leaves compound or divided, alternate, dilated at the base; flowers with the sepals and petals both imbricated in the bud, usually in two rows, the hypogynous stamens as many as the petals and opposite to them; fruit a berry or a pod.

I. Berberis. (Tourn.) L.

I. B. repens. Lindl. Rocky Mountain Grape.

2. B. aquifolium. Pursh. Oregon Grape.

\section{ORDER XIX. PAPAVERALES}

\section{PAPAVERACEE. POPPY FAMILY}

Herbs with milky or coloured juice, narcotic or acid; leaves alternate without stipules; flowers regular with the parts in twos or fours, fugacious sepals, polyandrous; fruit a dry pod with numerous seeds.

I. Papaver. (Tourn.) L.

I. P. alpinum. L. Arctic Poppy.

\section{FUMARIACEA. FUMITORY FAMILY}

Delicate smooth herbs with watery juice; leaves compound, dissected, usually alternate; flowers irregular, with four somewhat united petals, the outer with spreading tips, and one or both of 
them spurred or saccate at the base, the inner pair narrower, their callous-crested tips united over the stigma; fruit a pod containing one or more seeds.

I. Dicentra. Benth.

I. D. formosa. DC. Wild Bleeding-heart.

2. D. uniflora. Kell. One-flowered Bleeding-heart.

II. Corydalis. (Dill.) Medic.

I. C. aurea. Willd. Golden Corydalis.

\section{CRUCIFERE. MUSTARD FAMILY}

Herbs with pungent watery juice; leaves alternate; flowers cruciform, tetradynamous, regular, in terminal racemes or corymbs; fruit a silique or silicle, sometimes nut-like, the pods and seeds give the chief character of the genera.

TRIBE ALYSSEÆ

I. Draba. (Dill.) L.

I. D. incana. L. Winite Whitlow Grass.

2. D. lonchocarpa. Rydb. Long-podded Whitlow Grass.

3. D. præalta. Spring Whitlow Grass.

4. D. aurea. Vahl. Golden Whitlow Grass.

5. D. alpina. L. Alpine Whitlow Grass.

6. D. nivalis. Liljb. Arctic Whitlow Grass.

7. D. glacialis. Adams. Pale Yellow Whitlow Grass.

TRIBE PHYSARIEE

II. Physaria. Gray.

I. P. didymocarpa. (Hook.) Gray. Bladder-pod.

TRIBE LEPIDIEÆ

III. Thlaspi. (Tourn.) L.

I. T. arvense. L. Penny Cress. (Introduced.)

IV. Lepidium. (Tourn.) L.

I. L. apetalum. Willd. Pepper Grass.

TRIBE CAMELINEÆ

V. Capsella. Medic.

I. C. Bursa-pastoris. (L.) Medic. Shepherd's Purse. (Introduced.) 
VI. Neslia. Desv.

I. N. paniculata. (L.) Desv. Neslia. (Introduced.)

TRIBE BRASSICEÆ

VII. Brassica. (Tourn.) L.

I. B. Sinapistrum. Boiss. Herb of St. Barbara. (Introduced.)

TRIBE SISYMBRIEÆ

Vili. Sisymbrium. (Tourn.) L.

I. S. Hartwegianum. Fourn. Hartweg's Tansy Mustard.

2. S. altissimum. L. Tall Hedge Mustard. (Introduced.)

3. S. canescens. Nutt. Pale Tansy Mustard.

4. S. incisum. Engelm. Western Tansy Mustard.

IX. Braya. Sternb. and Hoppe.

I. B. humilis. (Mey.) Robinson. Northern Rock Cress.

X. Erysimum. (Tourn.) L.

I. E. parviflorum. Nutt. Treacle Mustard.

TRIBE ARABIDEÆ

XI. Radicula. (Dill.) Hill.

I. R. Nasturtium-aquaticum. (L.) Britten and Rendle. Water Cress. (Introduced.)

XiI. Cardamine. (Tourn.) L.

I. C. pennsylvanica. Muh1. White Bitter Cress.

2. C. bellidifolia. L. Alpine Bitter Cress.

XIII. Arabis. L.

I. A. Holbœllii. Hornem. Stony Rock Cress.

2. A. hirsuta. (L.) Scop. Hairy Rock Cress.

3. A. Drummondii. Gray. Drummond's Rock Cress.

4. A. glabra. (L.) Benth. Smooth Rock Cress.

5. A. Lyallii. Wats. Lyall's Rock Cress. 


\section{ORDER XX. SARRACENIALES}

\section{DROSERACEE. SUNDEW FAMILY}

Bog-herbs, mostly viscid-glandular; leaves in bud rolled up from the apex to the base as in ferns, alternate or crowded, entire ; flowers hypogynous, penstamerous, calyx imbricated, petals convolute; fruit a capsule, seeds numerous, anatropous.

I. Drosera. L.

I. D. rotundifolia. L. Round-leaved Sundew.

2. D. longifolia. L. Long-leaved Sundew.

\section{ORDER XXI. ROSALES}

\section{CRASSULACEA. ORPINE FAMILY}

Succulent smooth herbs; leaves simple, alternate, mostly sessile: flowers usually cymes, small, perfectly symmetrical; fruit a dry indehiscent pod opening down the ventral suture, many-seeded.

I. Sedum. (Tourn.) L.

I. S. roseum. (L.) Scop. Rosewort.

2. S. stenopetalum. Pursh. Stonecrop.

\section{SAXIFRAGACE正. SAXIFRAGE FAMILY}

Herbs or shrubs of various aspect, with bland or astringent juice; leaves alternate, sometimes opposite, or more frequently basal; flowers perfect, racemose, cymose or paniculate, stamens and petals nearly always inserted on the calyx; fruit capsular, usually beaked.

\section{TRIBE SAXIFRAGEÆ}

I. Leptarrhena. Brown.

I. L. amplexifolia. (Sternb.) ser. DC. Leptarrhena.

II. Boykinia. Nutt.

I. B. occidentalis. T. and G. Western Boykinia.

III. Saxifraga. (Tourn.) L.

I. S. bronchialis. L. Common Saxifrage.

2. S. cernua. L. Nodding Saxifrage. 
3. S. Lyallii. Engler. Lyall's Saxifrage.

4. S. nutkana. Moc. Engler. Tall Saxifrage.

5. S. nivalis. L. Alpine Saxifrage.

6. S. Mertensiana. Bong. Spotted Saxifrage.

7. S. æstivalis. Fisch. Purple-bracted Saxifrage.

8. S. cæspitosa. L. Tufted Saxifrage.

9. S. adscendens. L. Wedge-leaved Saxifrage.

ro. S. rivularis. L. Alpine Brook Saxifrage.

II. S. oppositifolia. L. Mountain Saxifrage.

12. S. aizoides. L. Yellow Saxifrage.

IV. Tiarella. L.

I. T. unifoliata. Hook. Nancy-over-the-ground.

V. Heuchera. L.

I. H. ovalifolia. Nutt. Oval-leaved Alum Root.

2. H. glabra. Willd. Smooth Alum Root.

3. H. glabella. T. and G. Bristly Alum Root.

VI. Lithophragma. Nutt.

I. L. tenella. Nutt. Woodland Star.

VII. Tellima. R. Br.

I. T. grandiflora. (Pursh.) Dougl. Tellima.

VIII. Mitella. (Tourn.) L.

I. M. Breweri. Gray. Mitrezvort.

2. M. nuda. L. Bishop's Cap.

3. M. pentandra. Hook. Five-stamened Mitrewort.

4. M. trifida. Graham. Alpine Mitrewort.

iX. Chrysosplenium. (Tourn.) L.

I. C. tetrandrum. Fries. Golden Saxifrage.

X. Parnassia. (Tourn.) L.

I. P. montanensis. Rydb. and Fernald. Marsh Grass of Parnassus.

2. P. fimbriata. Banks. Fringed Grass of Parnassus.

3. P. parviflora. DC. Small Grass of Parnassus.

4. P. Kotzebuei. Cham. Alpine Grass of Parnassus.

TRIBE RIBESIEÆ

XI. Ribes. L.

I. R. setosum. Lindl. Bristly Gooseberry.

2. R. lacustre. (Pers.) Poir. Swamp Gooseberry. 
3. R. hudsonianum. Richards. Black Currant.

4. R. laxiflorum. Pursh. Skunk Currant.

\section{ROSACEE. ROSE FAMILY}

Trees, shrubs or herbs; leaves alternate, simple or compound, mostly foliaceous with stipules; flowers perfect or unisexual, regular in cymes, corymbs, panicles or solitary, with numerous distinct stamens inserted on the calyx, sepals united at the base, often appearing double by a row of bractlets outside; fruit seeds, follicles, achenes or drupelets, with little or no albumen.

\section{TRIBE SPIRÆA}

I. Spirfea. (Tourn.) L.

I. S. lucida. Dougl. Birch-leaved Spirca.

2. S. densiflora. Nutt. Pink Spiraa.

II. Aruncus. (L.) Adans.

I. A. sylvester. (L.) Karst. Goat's Beard.

III. Lutkea. Bong.

I. L. pectinata. (Pursh.) Kuntze. Alpine Spirca.

TRIBE POMEÆ

IV. Pyrus. (Tourn.) L.

I. P. sambucifolia. C. and S. Western Mountain Ash.

V. Amelanchier. Medic.

r. A. florida. Lind. Common Serviceberry.

2. A. Cusickii. Fernald. Thick-leaved Serviceberry.

TRIBE POTENTILLEÆ

VI. Fragaria. (Tourn.) L.

I. F. glauca. Wild Strazuberry.

2. F. bracteata. Heller. Wood Strawberry.

ViI. Sibbaldia. L.

I. S. procumbens. L. Creeping Sibbaldia.

ViII. Potentilla. L.

I. P. Anserina. L. Silver Weed.

2. P. dissecta. Pursh. Common Cinquefoil.

3. P. dissecta var. glaucophylla. Smooth Cinquefoil. 
4. P. dissecta var. multisecta. (Wats.) Rydb. Dissected Cinquefoil.

5. P. dissecta var. pinnatisecta. Leafy Cinquefoil.

6. P. arguta. Pursh. Tall Cinquefoil.

7. P. norvegica. (L.) Rydb. Rough Cinquefoil.

8. P. Hippiana. Lehm. Woolly Cinquefoil.

9. P. gracilis. Dougl. Graceful Cinquefoil.

I0. P. nivea. L. Alpine Cinquefoil.

II. P. uniflora. Ledeb. One-flowered Cinquefoil.

I2. P. fruticosa. L. Shrubby Cinquefoil.

I3. P. palustris. (L.) Scop. Purple Cinquefoil.

IX. Geum. L.

I. G. triflorum. Pursh. Long-plumed Avens.

2. G. strictum. Ait. Yellow Avens.

3. G. macrophyllum. Willd. Large-leaved Avens.

TRIBE RUBEÆ

X. Rubus. (Tourn.) L.

I. R. parviflorus. Nutt. Capberry.

2. R. strigosus. Michx. Red Raspberry.

3. R. triflorus. Richards. Dwarf Raspberry.

4. R. pedatus. Smith. Creeping Raspberry.

5. R. arcticus. L. Arctic Raspberry.

6. R. spectabilis. Pursh. Salmonberry.

TRIBE ROSEÆ

XI. Dryas. L.

I. D. octopetala. L. Wood Nymphs.

2. D. Drummondii. Richards. Drummond's Dryas.

XII. Rosa. (Tourn.) L.

I. R. acicularis. Lindl. Prickly Rose.

2. R. Macounii. Macoun's Rose.

3. R. gymnocarpa. Nutt. Tiny Rose.

TRIBE PRUNEÆ

XIII. Prunus. (Tourn.) L.

I. P. demissa. (Nutt.) Dietrich. Western Choke Cherry. 


\section{LEGUMINOSA. PULSE FAMILY}

A very large family of shrubs, herbs and vines; leaves alternate, with stipules, usually compound; flowers mainly in racemes or axillary, terminal, solitary or capitate, papilionaceous or sometimes regular, the single simple free pistil becoming a legume in fruit; fruit seeds solitary or several, without albumen.

\section{SUBFAMILY PAPILIONOIDEÆ}

I. Lupinus. (Tourn.) L.

I. L. subalpinus. P. and R. Alpine Lupin.

II. Trifolium. (Tourn.) L.

I. T. repens. L. White Clover. (Introduced.)

2. T. hybridum. L. Alsatian Clover. (Introduced.)

3. T. pratense. L. Red Clover. (Introduced.)

III. Melilotus. (Tourn.) Hill.

I. M. officinalis. (L.) Lam. Yellow Melilot. (Introduced.)

IV. Astragalus. (Tourn.) L.

I. A. aboriginorum. Richards. Indian Milk $V$ ctch.

2. A. tenellus. Pursh. Loose-flowered Milk Vetch.

3. A. adsurgens. Pall. Ascending Milk Vetch.

4. A. hypoglottis. L. Purple Milk Vetch.

5. A. alpinus. L. Alpine Milk Vetch.

6. A. Macounii. Macoun's Milk Vetch.

V. Phaca. L.

7. A. convallarius. Greene. Slender Milk Vetch.

I. P. americana. (Hook.) Rydb. Lentil Vetch.

VI. Oxytropis. DC.

I. O. viscida. Nutt. Alpine Oxytrope.

2. O. splendens. Dougl. Showy Oxytrope.

3. O. deflexa. Drooping-fruited Oxytrope.

4. O. podocarpa. Gray. Inflated Oxytrope.

5. O. Lamberti. (Pursh.) Kuntze. Locoweed.

6. O. monticola. Gray. Mountain Oxytrope.

VII. Hedysarum. (Tourn.) L.

I. H. boreale. Nutt. Purple Hedysarum. 
2. H. sulphurescens. Rydb. Whitc Hedysarum.

VIII. VICIA. Tourn.

3. H. Mackenzii. Richards. Mackenzic's Hedysarum.

I. V. Cracca. L. Cow Vetch. (Introduced.)

2. V. americana. Muhl. American Vetch.

IX. Lathyrus. L.

I. L. ochroleucus. Hook. White Vetchling.

2. L. palustris. L. Marsh Vetchling.

\section{ORDER XXII. GERANIALES XXXIX. LINACEA. FLAX FAMILY}

Herbs or more rarely low shrubs; leaves simple, entire, sessile, alternate, opposite or subverticillate below; flowers cymose, hermaphrodite, regular, symmetrical, hypogynous, the calyx strongly imbricated, petals convolute in the bud; fruit a many-seeded pod, having twice as many cells as there are styles, seeds oily.

I. Linum. (Tourn.) L.

I. L. Lewisii. Pursh. Wild Flax.

\section{GERANIACEÆ. GERANIUM FAMILY}

Plants with astringent roots; leaves toothed, lobed or divided, stipulate; flowers hypogynous, perfect, regular, numerous, sepals imbricated in the bud, persistent; fruit ovary deeply lobed, carpels two-ovuled, one-seeded, separating elastically with their long styles when mature from the elongated axis.

I. Geranium. (Tourn.) L.

I. G. Richardsonii. F. and M. White Geranium.

2. G. carolinianum. L. Carolina Crane's Bill.

3. G. Bicknellii. Britton. Bicknell's Geranium.

\section{CALLITRICHACEAE. WATER STARWORT FAMILY}

Chiefly aquatic herbs, low, slender, usually tufted; leaves entire, spatulate or linear; flowers monœcious, solitary or a few together in the axil of the leaf, wholly naked or enclosed by a pair of 
membranaceous bracts; fruit nut-like, compressed, seeds pendulous.

I. Callitriche. L.

I. C. palustris. L. Water Fennel.

\section{ORDER XXIII. SAPINDALES}

\section{EMPETRACEÆ. CROWBERRY FAMILY}

Low evergreen shrubs with the foliage aspect and compound pollen of Heaths and drupaceous fruit. Probably just an apetalous and degenerate form of Ericaceæ and comprising three genera, only one of which is found within the limits of this book.

I. Empetrum. (Tourn.) L.

I. E. nigrum. L. Crowberry.

\section{CELASTRACEE. STAFF TREE FAMILY}

Shrubs and shrubby climbers or trees; leaves simple, evergreen; flowers perfect, regular, small, the petals as many as the sepals and alternate with them; fruit free from the calyx, embryo large in fleshy albumen, seeds arilled.

I. Pachistima. Raf.

I. P. Myrsinites. Raf. Mountain Lover.

\section{ACERACEA. MAPLE FAMILY}

Trees or shrubs with watery often saccharine sap; leaves opposite, simple, palmately lobed or more rarely pinnately divided; flowers axillary, terminal, cymose or racemose, small, regular, mostly polygamous or diœcious, sometimes apetalous; fruit two long-winged samaras joined at the base.

I. ACER. (Tourn.) L.

I. A. glabrum. Torr. Dwarf Maple.

\section{HYPERICACEA. ST. JOHN'S-WORT FAMILY}

Herbs or shrubs; leaves opposite, entire, with black dots or lines, mostly sessile, punctate with resinous glands, no stipules; 
flowers solitary or cymose, regular, hypogynous, the petals mostly oblique, convolute in the bud; fruit the pod one-celled with twofive parietal placentæ, seeds numerous, small, anatropous, with no albumen.

I. Hypericum. (Tourn.) L.

I. H. Scouleri. Hook. Scouler's St. John's-wort.

\section{ORDER XXIV. VIOLALES}

\section{VIOLACEA. VIOLET FAMILY}

Herbs perennial or annual; leaves basal or alternate, simple, with stipules; flowers axillary, nodding, corolla irregular, onespurred or gibbous of five petals imbricated in the bud; fruit a capsule, ovoid, seeds with a hard smooth coat.

I. Viola. (Tourn.) L.

I. V. canadensis. L. Canada Violet.

2. V. nephrophylla. Greene. Early Violet.

3. V. adunca. Smith. Dog Violet.

4. V. Selkirkii. Pursh. Selkirk's Violet.

5. V. palustris. L. Marsh Violet.

6. V. glabella. Nutt. Yellow Violet.

7. V. orbiculata. Geyer. Round-leaved Yellow Violet.

8. V. sempervirens. Greene. Trailing Yellow Violet.

\section{ORDER XXV. MYRTALES}

\section{ELAAGNACEÆ. OLEASTER FAMILY}

Shrubs or small trees; leaves silvery-scurfy or stellate-pubescent, entire, opposite or alternate; flowers perfect-polygamous or diœcious, clustered in the axils or at the nodes of twigs of the previous season, rarely solitary; fruit drupe-like, the base of the calyx becoming thick and pulpy, strictly inclosing the achene or nut.

I. Elziagnus. (Tourn.) L.

I. E. argentea. Pursh. Silvcrberry.

II. Shepherdia. Nutt.

I. S. canadensis. (L.) Nutt. Canada Buffaloberry. 


\section{ONAGRACEA. EVENING PRIMROSE FAMILY}

Herbaceous or shrubby plants; leaves entire or toothed, alternate or opposite; flowers axillary or in terminal spikes, perfect, symmetrical, calyx-tube adnate to the ovary, its lobes valvate in the bud or obsolete, petals convolute in the bud, sometimes wanting; fruit a many-seeded pod, seeds mostly silky-tufted.

I. Epilobium. L.

I. E. alpinum. L. Alpine Willow-herb.

2. E. angustifolium. L. Great Willow-herb.

3. E. latifolium. L. Water Willow-herb.

4. E. anagallidifolium. Lam. Mountain Willow-herb.

5. E. Hornemanni. Reichenb. Hornemann's Willowherb.

6. E. paniculatum. Nutt. Panicled Willow-herb.

7. E. clavatum. Trel. Few-flowered Willow-herb.

8. E. adenocaulon. Haussk. Northern Willow-herb.

9. E. luteum. Pursh. Yellow Willow-herb.

II. Enothera. L.

I. O. biennis. L. Common Evening Primrose.

III. Circesa. (Tourn.) L.

I. C. pacifica. Asch. and Mag. Pacific Enchanter's Nightshade.

2. C. alpina. L. Small Enchanter's Nightshade.

\section{HALORAGIDACEÆ. WATER MILFOIL FAMILY}

Aquatic or marsh plants; leaves various, crowded, often whorled; flowers inconspicuous, symmetrical, sessile in the axils of the leaves or bracts; fruit dry and indehiscent, with a single anatropous seed suspended from the summit of each cell.

I. Myriophyllum. (Vaill.) L.

I. M. spicatum. L. Spiked Water Milfoil.

II. Hippuris. L.

I. H. vulgaris. L. Bottle Brush.

2. H. montana. Ledeb. Mountain Mare's Tail, 


\section{ORDER XXVI. UMBELLALES}

\section{ARALIACEÆ. GINSENG FAMILY}

Herbs, shrubs or trees; leaves alternate, verticilliate, simple or compound, without stipules, the petioles thickened and dilated at the base; flowers umbellate, paniculate or racemose, the calyxtube adnate to the ovary, the petals sometimes cohering together, epigynous, not inflexed; fruit a few-celled drupe.

I. Aralia. (Tourn.) L.

I. A. nudicaulis. L. Wild Sarsaparilla.

II. Fatsia. Dene and Planch.

I. F. horrida. (Sm.) B. and H. Devil's Club.

\section{UMBELLIFERA. PARSLEY FAMILY}

A large family of herbs, some innocent, others very poisonous; leaves alternate, mostly compound, the petioles expanded or sheathing at the base; flowers small in umbels and umbellets, usually subtended by an involucre; fruit dry, of two mericarps cohering by their inner face, separating when ripe, each carpel ribbed lengthwise, the tubes between the ribs containing aromatic coloured oil.

I. Osmorhiza. Raf.

I. O. obtusa. (C. and R.) Fernald. Crisp-leaved Sweet Ciccly.

2. O. divaricata. Nutt. Western Sweet Cicely.

II. Zizia. Koch.

I. Z. cordata. (Walt.) DC. Heart-leaved Alexanders.

III. Ligusticum. L.

I. L. apiifolium. Gray. Fern-leaved Lovage.

2. L. Grayi. C. and R. Gray's Lovage.

IV. Lomatium. Raf.

I. L. macrocarpum. (Nutt.) C. and R. Large-seeded Parsley.

2. L. triternatum. (Pursh.) C. and R. Narrow-leaved Parsley.

3. L. Martindalei var. angustatum. C. and R. Martindale's Parsley. 
V. Heracleum. L.

I. H. lanatum. Michx. Cow Parsnip.

VI. Leptotenia. Nutt.

I. L. multifida. Nutt. Cut-leaved Angelica.

\section{CORNACEE. DOGWOOD FAMILY}

Shrubs or trees with bitter tonic bark; leaves opposite or alternate, simple, usually entire, pinnately veined, without stipules; flowers perfect, cymose or capitate, rarely solitary, with or without an involucre, petals distinct, as many as the calyx-lobes and alternate with them, inserted on the margin of the epigynous disk; fruit drupelets covered with the remains of the calyx.

I. Cornus. (Tourn.) L.

I. C. canadensis. L. Bunchberry.

2. C. stolonifera. Michx. Red-osier Dogwood.

Subclass II. Metachlamydece

\section{ORDER XXVII. ERICALES}

\section{ERICACEE. HEATH FAMILY}

A large family of shrubs and herbs; leaves simple, oblong or linear, deciduous or evergreen; flowers racemose, corymbose or solitary, regular, mostly perfect, without stipules, sometimes from scaly buds; fruit a capsule, berry or drupe.

\section{SUBFAMILY PYROLOIDEÆ}

TRIBE PYROLEÆ

I. Chimaphila. Pursh.

I. C. umbellata. (L.) Nutt. Pipsisserva.

2. C. Menziesii. Spreng. Spotted Prince's Pine.

II. Moneses. Salisb.

I. M. uniflora. (L.) Gray. One-flowered Wintergreen.

III. Pyrola. (Tourn.) L.

I. P. chlorantha. Sw. Green-flowered Wintergreen.

2. P. secunda. L. One-sided Wintergreen.

3. P. minor. L. Small Wintergreen. 
4. P. asarifolia. Michx. Bog Wintergreen.

5. P. asarifolia var. incarnata. (Fisch.) Fernald. Red Wintergreen.

\section{SUBFAMILY MONOTROPOIDEÆ}

IV. Allotropa. T. and G.

I. A. virgata. T. and G. Striped Allotropa.

V. Monotropa. L.

I. M. uniflora. L. Indian Pipe.

2. M. Hypopitys. L. Pinesap.

VI. Pterospora. Nutt.

I. P. Andromedea. Nutt. Pine Drops.

VII. NewberRya. Torr.

I. N. congesta. Torr. Newberrya.

\section{SUBFAMILY ERICOIDEÆ}

TRIBE RHODODENDREÆ

VIII. LEDUM. L.

I. L. grœnlandicum. Oeder. Woolly Labrador Tea.

2. L. glandulosum. Nutt. Smooth-leaved Labrador Tea.

IX. RHODODENDRON. L.

I. R. albiflorum. Hook. Mountain Rhododendron.

X. Menziesia. Sm.

I. M. glabella. Gray. Smooth Menziesia.

2. M. ferruginea. Smith. Scaly Menziesia.

Xi. Loiseleuria. Desv.

I. L. procumbens. (L.) Desv. Trailing Alpine Azalea.

XII. Kalmia. L.

I. K. polifolia. Wang. Swamp Laurel.

TRIBE ANDROMEDEÆ

XiII. Bryanthus. Gmel.

I. B. empetriformis. Gray. Red Mountain Heather.

2. B. glanduliflorus. Gray. White Mountain Heather.

3. B. intermedius. (Hook.) Rydb. Pink Mountain Heather. 
XiV. Cassiope. D. Don.

I. C. Mertensiana. (Bong.) Don. White Heath.

2. C. tetragona. Don. Four-angled Heath.

XV. Gaultheria. (Kalm.) L.

I. G. ovatifolia. Gray. Red-berried Gaultheria.

2. G. humifusa. (Graham.) Rydb. Creeping Gaultheria.

TRIBE ARBUTEÆ

XVI. Arctostaphylos. Adans.

I. A. Uva-ursi. (L.) Spreng. Red Bearberry.

2. A. alpina. (L.) Spreng. Alpine Bearberry.

3. A. tomentosa. Dougl. Manzanita.

SUBFAMILY VACCINOIDEÆ

XViI. Vaccinuium. L.

I. V. ovalifolium. Sm. Oval-leaved Blueberry.

2. V. membranaceum. Dougl. Black Blucberry.

3. V. cæspitosum. Michx. Dwarf Bilberry.

4. V. Vitis-Idæa. L. Mountain Bilberry.

5. V. erythrococcum. Michx. Alpine Bilberry.

6. V. Oxycoccus. L. Small Cranberry.

\section{ORDER XXVIII. PRIMULALES}

\section{PRIMULACEE. PRIMROSE FAMILY}

Herbs; leaves simple, opposite or alternate, basal or whorled on the stem; flowers racemose or verticillate, sometimes axillary, regular, perfect, calyx free from the ovary, the stamens as many as the lobes of the gamopetalous corolla ; fruit a capsule, dehiscent.

I. Primula. L.

I. P. farinosa. L. Bird's Eye Primrose.

2. P. Maccalliana. Weigand. Dwarf Canada Primrose.

II. Androsace. (Tourn.) L.

I. A. chamæjasme. Sweet Androsace.

2. A. septentrionalis. L. Alpine Androsace.

3. A. diffusa. Small. Spreading Androsace. 
III. Trientalis. L.

I. T. arctica. Fisch. Star-flcwer.

IV. Dodecatheon. L.

I. D. pauciflorum. (Durand.) Greene. Shooting Star.

\section{ORDER XXIX. GENTIANALES \\ LV. GENTIANACEA. GENTIAN FAMILY}

Smooth herbs with a bitter colourless juice; leaves opposite, sessile, entire, simple, without stipules; flowers regular, perfect, in clusters, axillary or solitary at the ends of the stems; fruit usually a two-valved septicidal many-seeded capsule.

I. Gentiana. (Tourn.) L.

I. G. Macounii. Macoun's Gentian.

2. G. Amarella L. var. acuta. Michx. Northern Gentian.

3. G. propinqua. Richards. Four-patted Gentian.

4. G. arctophila. Alpine Gentian.

5. G. prostrata. Haenke. Dwarf Gentian.

6. G. affinis. Griseb. Large Gentian.

7. G. glauca. Pale Gentian.

iI. Halenia. Borkh.

I. H. deflexa. (Sm.) Griseb. Spurred Gentian. SUBFAMILY MENYANTHOIDEÆ

III. Menyanthes. (Tourn.) L.

I. M. trifoliata. L. Marsh Buckbean.

\section{APOCYNACEE. DOGBANE FAMILY}

Perennial herbs or shrubs, mostly with milky acrid juice; leaves entire, opposite or alternate, without stipules; flowers regular., the lobes of the corolla convolute and often twisted in the bud, calyx free from the two ovaries which are distinct; fruit slender elongated terete seed-pods, seeds often comose.

I. Apocynum. (Tourn.) L.

I. A. androsæmifolium. L. Spreading Dogbane. 


\section{ORDER XXX. POLEMONIALES}

\section{POLEMONIACEA. POLEMONIUM FAMILY}

Herbs; leaves alternate or opposite, regular; flowers with persistent calyx, corolla lobes convolute in the bud, a three-celled ovary, three-lobed style; fruit seeds amphitropous, the coat frequently mucilaginous when moistened and emitting spiral threads.

I. Phlox. L.

I. P. Douglasii. Hook. Alpine Phlox.

II. Grlia. Rinz and Pav.

I. G. aggregata. Spreng. Scarlet Gilia.

III. Polemonium. (Tourn.) L.

I. P. confertum. Gray. Blue Greek Valerian.

2. P. humile. Willd. Purple Greek Valerian.

\section{HYDROPHYLLACEA. WATERLEAF FAMILY}

Herbs commonly rough-hairy, with colourless insipid juice; leaves mostly alternate, sometimes opposite or basal, round-reniform or cordate; flowers regular in spikes, false racemes or scorpioid cymes, curled when in bud and uncoiling as they flower; fruit a two-valved many-seeded capsule, the seeds mostly reticulated or pitted.

I. Phacelia. Juss.

I. P. sericea. (Graham.) Gray. Mountain Phacelia.

2. P. heterophylla. Pursh. Blue Phacelia.

II. Romanzoffia. Cham.

I. R. sitchensis. Bong. Mist Maidens.

\section{BORAGINACEE. BORAGE FAMILY}

Chiefly mucilaginous herbs with hairy stems; leaves alternate, rarely opposite, entire, without stipules; flowers perfect, symmetrical, mostly on one side of the branches in a reduced cyme, occasionally leafy-bracted, imitating a raceme, rolled up from the tip and straightening out as it flowers; fruit four nutlets, sometimes armed with barbed prickles, or a drupe. 
TRIBE BORAGINEÆ

I. Lappula. (Rivinius.) Moench.

I. L. floribunda. (Lehm.) Greene. False Forget-menot.

2. L. diffusa. (Lehm.) Greene. Rock Stickseed.

3. L. echinata. Gilibert. Burseed. (Introduced.)

II. Mrosotis. (Rupp.) L.

I. M. alpestris. Schmidt. Mountain Forget-me-not.

III. Mertensia. Roth.

I. M. paniculata. (Ait.) G. Don. Tall Lungwort.

2. M. oblongifolia. Don. Blue Lungwort.

IV. Lithospermum. (Tourn.) L.

I. L. angustifolium. Michx. Narrow-leaved Puccoon.

2. L. ruderale. Dougl. Lehm. Hairy Puccoon.

\section{LABIAT尼. MINT FAMILY}

Chiefly herbs with square stems; leaves simple, opposite, aromatic, mostly dotted with small glands containing a volatile oil; flowers irregular, perfect, axillary, chiefly in cymose clusters, these often aggregated in terminal spikes or racemes; fruit four small smooth seed-like nutlets or achenes, each containing a single erect seed.

\section{TRIBE STACHYEÆ}

I. Dracocephalum. (Tourn.) L.

I. D. parviflorum. Nutt. Dragon Head.

II. Prunella. L.

I. P. vulgaris. L. Heart-of-the-earth.

III. Stachys. (Tourn.) L.

I. S. palustris. L. Woundwort.

IV. MONARDA. L.

I. M. fistulosa. L. Wild Bergamot.

V. Mentha. (Tourn.) L.

I. M. canadensis. L. Canada Mint.

2. M. canadensis var. lanata. Piper. Hairy Mint. 


\section{SCROPHULARIACEÆ. FIGWORT FAMILY}

Herbs, shrubs or rarely trees, bitterish, occasionally narcoticpoisonous; leaves alternate or opposite, without stipules, very various; flowers perfect, mostly complete, irregular, corolla two-lipped, inflorescence very various; fruit a two-celled and usually manyseeded calsule.

\section{SUBFAMILY ANTIRRHINOIDEÆ}

TRIBE CHELONEÆ

I. Collinsia. Nutt.

I. C. tenella. Pursh. Blue-eyed Mary.

II. Penstemon. (Mitchell.) Ait.

I. P. fruticosus. (Pursh.) Greene. Large Purple Beard-tongue.

2. P. Menziesii. Hook. Small-leaved Beard-tongue.

3. P. procerus. Dougl. Blue Beard-tongue.

4. P. humilis. Nutt. Slender Beard-tongue.

5. P. confertus. Dougl. Yellow Beard-tongue.

TRIBE GRATIOLEÆ

III. Mimulus. L.

I. M. Lewisii. Pursh. Red Monkey Flozver.

2. M. Langsdorfii. Donn. Yellow Monkcy Flower.

3. M. moschatus. Dougl. Musk Flower.

4. M. alpinus. Gray. Alpinz Monkey Flower.

\section{SUBFAMILY RHINANTHOIDEÆ}

TRIBE DIGITALEÆ

IV. Veronica. (Tourn.) L.

I. V. alpina L. var. unalaschensis. C. and S. Alpine Speedruçll.

2. V. humifusa. Dickson. Thyme-leaved Speedwell.

3. V. americana. Schwein. Water Speedwell. 
TRIBE EUPHRASIEÆ

V. Castilleja. Mutis.

I. C. miniata. Dougl. Red Indian Paint Brush.

2. C. pallida. Kunth. White Indian Paint Brush.

3. C. purpurascens. Greenman. Purple Indian Paint Brush.

4. C. lancifolia. Rydb. Lance-leaved Indian Paint Brush.

5. C. angustifolia var. Bradburii. (Nutt.) Fernald. Bradbury's Painted Cup.

6. C. rupicola. Piper. Bright Painted Cup.

7. C. oreopala. Greenman. Magenta Painted Cup.

VI. Orthocarpus. Nutt.

I. O. luteus. Nutt. Pelican Flower.

VII. Pedicularis. (Tourn.) L.

I. P. racemosa. Dougl. White Lousewort.

2. P. contorta. Benth. Contorted Lousezvort.

3. P. bracteosa. Benth. Western Wood Betony.

4. P. grœnlandica. Elephant's Head.

VIII. Rhinanthus. L.

I. R. Crista-galli. L. Yellow Rattle.

\section{LENTIBULARIACEE. BLADDERWORT FAMILY}

Small wet-loving herbs, terrestial; leaves basal, entire, tufted, the upper surface covered with a viscid secretion when floating, opposite or verticillate; flowers solitary or racemose on scapes or scapelike peduncles, corolla deeply bilabiate, the upper lip usually erect, concave, spreading or reflexed, three-lobed, with a prominent palate, spurred at the base in front, the palate usually bearded; fruit a capsule, often irregularly bursting or dehiscent by valves.

I. Utricularia. L.

I. U. vulgaris. L. var. americana. Gray. Greater Bladderwort.

2. U. intermedia. Hayne. Yellow Bladderwort.

II. Pinguicula. (Tourn.) L.

I. P. vulgaris. L. Butterwort. 


\section{OROBANCHACEA. BROOM-RABE FAMILY}

Herbs (root parasites) destitute of green foliage; flowers solitary or spiked, corolla tubular, more or less two-lipped, the lower three-lobed; fruit a capsule one-celled, two-valved, seeds numerous, minute.

I. Orobanche. (Tourn.) L.

I. O. uniflora. L. One-flowered Cancer-root.

2. O. fasciculata. Nutt. Naked Cancer-root.

II. Boschniakia. Gray.

I. B. strobilacea. Gray. Boschniakia.

\section{ORDER XXXI. PLANTAGINALES}

\section{PLANTAGINACEE. PLANTAIN FAMILY}

Chiefly stemless aquatic or terrestrial herbs; leaves radical, spreading, ovate or linear, entire; flowers small, regular in bracted spikes or heads, rarely solitary on scapes or scape-like peduncles; fruit a pyxis or an indehiscent nutlet.

I. Plantago. (Tourn.) L.

I. P. major. L. Common Plantain.

2. P. major var. asiatica. (L.) Dene. Asiatic Plantain. (Introduced.)

\section{ORDER XXXII. RUBIALES}

\section{RUBIACEE. MADDER FAMILY}

Herbs, shrubs or trees; leaves opposite, entire connected by interposed stipules or in whorls without apparent stipules; flowers perfect, regular, but often dimorphous; fruit dry or fleshy, separating into two carpels.

I. Galium. L.

I. G. boreale. L. Northern Bedstraw.

2. G. triflorum. Michx. Siveet-scented Bedstraw.

3. G. trifidum. L. Small Bedstraw. 


\section{CAPRIFOLIACEIE. HONEYSUCKLE FAMILY}

Shrubs, vines or rarely herbs; leaves opposite; flowers mostly cymose and terminal, sometimes axillary, the calyx-tube adnate to the ovary, the corolla tubular or rotate; fruit a berry, drupe or pod.

\section{TRIBE LONICERE压}

I. LONicera. L.

I. L. glaucescens. Rydb. Smooth-leaved Honeysuckle.

2. L. involucrata. (Richards.) Banks. Involucred Fly Honeysuckle.

3. L. utahensis. Wats. Bush Fly Honeysuckle.

II. Symphoricarpus. (Dill.) Ludwig.

I. S. racemosus Michx. var. pauciflorus. Robbins. Snowberry.

III. LinnæA. (Gronov.)

I. L. borealis L. var. americana. (Forbes.) Rehder. Northern Twin Flower.

TRIBE SAMBUCE $Æ$

IV. Viburnum. (Tourn.) L.

I. V. pauciflorum. Raf. Arrow-wood.

V. Sambucus. (Tourn.) L.

I. S. racemosa. L. Red-beriied Elder.

2. S. melanocarpa. Gray. Black-berried Elder.

\section{VALERIANACEAE. VALERIAN FAMILY}

Herbs with sometimes odorous and antispasmodic roots; leaves opposite, simple or divided, without stipules; flowers small, in panicles or dichotomous cymes, corolla tubular or funnel-form, often irregular, the lobes imbricated in the bud; fruit membranaceous or corriaceous, indehiscent.

I. Valeriana. (Tourn.) L.

I. V. septentrionalis. Northern Heliotrope.

2. V. sitchensis. Bong. Wild Heliotrope.

3. V. Scouleri. Rydb. Canada Heliotrope. 


\section{ORDER XXXIII. CAMPANULALES}

\section{CAMPANULACEA. BLUEBELL FAMILY}

Herbs usually with milky juice; leaves alternate, simple, without stipules; flowers scattered, perfect, the regular five-lobed corolla bell-shaped, valvate or induplicate in the bud; fruit a small many-seeded capsule or berry.

\section{Campanula. (Tourn.) L.}

I. C. rotundifolia. L. Harebell.

2. C. lasiocarpa. Arctic Harebell.

\section{LOBELIACEÆ. LOBELIA FAMILY}

Herbs usually with acrid milky juice; leaves alternate, without stipules; flowers perfect, scattered in loose bracted racemes, corolla irregular, gamopetalous, five-lobed, somewhat two-lipped; fruit a many-seeded pod.

I. Lobelia. (Plumier.) L.

I. L. Kalmii. L. Brook Lobclia.

\section{COMPOSIT桾. COMPOSITE FAMILY}

The largest family of phænogamous plants; herbs, shrubs or small trees; leaves various, alternate, opposite or basal; flowers in a dense closely involucrate head on a common receptacle, the head often resembling a single flower, surrounded by an involucre of few to many bracts in one or more series, the pappus crown-like or wanting, heads with ray-flowers are radiate, when without rayflowers are discoid; fruit an achene containing a single erect anatropous seed.

\section{SERIES I. TUBULIFLORÆ}

TRIBE ASTEREÆ

I. Chirysopsis. Nutt.

I. C. villosa. Nutt. Golden Astcr.

2. C. hispida. (Hook.) Hairy Golden Aster. 
II. Solidago. L.

I. S. canadensis. L. Canada Golden-rod.

2. S. decumbens. Greene. Field Goldcn-rod.

3. S. multiradiata. Gray. Northern Golden-rod.

4. S. missouriensis. Nutt. Mountain Golden-rod.

5. S. nemoralis. Ait. Gray Golden-rod.

6. S. elongata. Nutt. Slender Golden-rod.

III. Aster. (Tourn.) L.

I. A. commutatus. (T. and G.) Gray. White Aster.

2. A. alpinus. Alpine Aster.

3. A. conspicuous. Lindl. Large Purple Aster.

4. A. Fremonti. (T. and G.) Gray. Fremont's Aster.

5. A. frondeus. (Gray.) Greene. Leafy-bracted Aster.

6. A. Engelmanni. Englemann's Aster.

7. A. Lindleyanus. T. and G. Lindley's Aster.

8. A. lævis. L. Smooth Astcr.

9. A. Richardsonii. Spreng. Richardson's Aster.

Io. A. major. (Hook.) Porter. Great Northern Aster.

I. A. ciliomarginatus. Rydb. Hairy-margined Aster.

I2. A. sibiricus. Violet Aster.

IV. Erigeron. L.

I. E. aureus. Greene. Yellow Flcabane.

2. E. compositus. Pursh. Fern-leaved Fleabane.

3. E. multifidus. Rydb. Daisy Fleabane.

4. E. melanocephalus. Nelson. Black-zwoolly Fleabane.

5. E. cæspitosus. Nutt. Tufted Fleabane.

6. E. glabellus. Nutt. Rough Fleabane.

7. E. acris. L. Blue Fleabane.

8. E. philadelphicus. L. Lavender Flcabane.

9. E. uniflorus. L. Arctic Fleabane.

Io. E. lanatus. Hook. Alpine Fleabane.

II. E. salsuginosus. (Richards.) Gray. Large Purple Flcabane.

\section{TRIBE INULEÆ}

V. Antennaria. Gaertn.

I, A. racemosa. Hook. White Everlasting. 
2. A. Howellii. Greene. Mousc-ear Evcrlasting.

3. A. parvifolia. Nutt. Mountain Everlasting.

4. A. lanata. (Hook.) Greene. Arctic Everlasting.

5. A. pulcherrima. Greene. Tall Everlasting.

6. A. alpina. Gray. Alpine Everlasting.

7. A. media. Greene. Silky Everlasting.

8. A. rosea. Greene. Pink Everlastıng.

VI. Anaphalis. DC.
I. A. margaritacea. ing.
(L.) B. and H. Pearly Everlast-

TRIBE HELIANTHEÆ

VII. RUdBeCKiA. L.

I. R. hirta. L. Black-eyed Susan.

Vili. Helianthus. L.

I. H. giganteous. L. Giant Sunflower.

TRIBE HELENINEÆ

IX. Gaillardia. Foug.

I. G. aristata. Pursh. Brown-eyed Susan.

TRIBE ANTHEMIDEÆ

X. Achillea. (Vaill.) L.

I. A. lanulosa. Nutt. Woolly Yarrow.

2. A. borealis. Bong. Dark-margined Yarrow.

XI. Chrysanthemum. (Tourn.) L.

I. C. Leucanthemum. L. Ox-eye Daisy. (Introduced.)

XII. Artemisia. L.

I. A. frigida. Willd. Pasture Wormzwood.

2. A. discolor. Dougl. Green Wormzwood.

3. A. biennis. Willd. Biennial Wormwood.

TRIBE SENECIONEÆ

XiII. Petasites. (Tourn.) Hill.

1 P. palmatus. (Ait.) Gray. Palm-leaved Coltsfoot.

\& P. sagitatus. (Pursh.) Gray. Arrow-leaved Coltstoot.

¿. P. frigidus. (L.) Fries. Arctic Coltsfoot. 
XIV. Arnica. L.

I. A. cordifolia. Hook. Heart-leaved Arnica.

2. A. latifolia. Bong. Broad-leaved Arnica.

3. A. alpina. (L.) Olin. Alpine Arnica.

4. A. Chamissonis. Less. Chamisso's Arnica.

5. A. Parryi. Gray. Parry's Arnica.

6. A. louiseana. Farr. Schaeffer's Arnica.

7. A. fulgens. Pursh. Notclied Arnica.

8. A. gracilis. Rydb. Slender Arnica.

XV. Senecio. (Tourn.) L.

I. S. Balsamitæ. Muhl. Golden Ragwort.

2. S. triangularis. Hook. Giant Ragwort.

3. S. canus. Hook. Silvery Groundsel.

4. S. lugens. Richards. Black-tipped Groundsel.

5. S. pseudaureus. Rydb. Canada Ragwort.

6. S. discoideus. (Hook.) Britton. Northern Squaruweed.

7. S. flavovirens. Rydb. Western Balsam Groundsel.

\section{TRIBE CYNAREÆ}

XVI. Saussurea.

I. S. densa. Hook. Purple Saussurea.

XVII. Carduus. (Tourn.) L.

I. C. Kelseyi. White Thistle.

2. C. foliosus. Hook. Leafy Thistle.

3. C. undulatus. Nutt. Wavy-leaved Thistle.

\section{SERIES II. LIGULIFLORA}

\section{TRIBE CICHORIE E}

\section{Cichorium. (Tourn.) L.}

I. C. Intybus. L. Chicory.

XiX. Taraxacum. (Haller.) Ludwig.

I. T. officinale. Weber. Common Dandelion.

2. T. rupestre. Alpine Dandelion.

XX. Sonchus. (Tourn.) L.

I. S. arvensis. L. Sow Thistle. 
XXI. Agoseris. Raf.

I. A. glauca. (Pursh.) Steud. Large-flowered False Dandclion.

2. A. gracilens. Gray. Small-flowered False Dandelion.

3. A. aurantiaca. (Hook.) Greene. Copper False Dandelion.

XXII. Crepis. L.

I. C. elegans. Hook. Many-flowered Hawksbcard.

2. C. nana. Richards. Alpine Hawksbeard.

XXIII. Hieracium. (Tourn.) L.

I. H. Scouleri. Hook. Hairy Hawkweed.

2. H. gracile. Hook. Small Hawkweed.

3. H. umbellatum. L. Narrow-leaved Hawkweed. 
WILD FLOWERS OF THE NORTH

AMERICAN MOUNTAINS

SECTION I

FERNS AND FERN ALLIES 



\title{
WILD FLOWERS OF THE NORTH AMERICAN MOUNTAINS
}

\author{
SECTION I \\ FERNS AND FERN ALLIES
}

\section{LONG BEECH FERN}

Phegopteris polypodioides. Fern Family

Rootstock: slender, creeping. Leaves: triangular, thin, mostly longer than wide, acuminate at the apex, pubescent; pinnæ lanceolate, sessile, pinnately parted very nearly to the rachis into oblong, entire segments. Sori: small, borne near the margin.

A common fern on the hillsides, and in moist woods. The fronds are from six to nine inches long, and the two lowest pinnæ are bent downwards and stand forward, a trait which gives the plant a most distinctive appearance, and by which it may always be readily recognized.

Phegopteris alpestris, or Tufted Beech Fern, has oblong leaves which taper towards the top.

Phegopteris Dryopteris, or Oak Fern, is extremely attractive, and grows very thickly in shady woods. The leaves are delicate and broadly triangular, the three primary divisions being stalked, and the terminal one slightly the largest. In Shakespeare's day "fern-seed" as they called the spores 
PLATE I

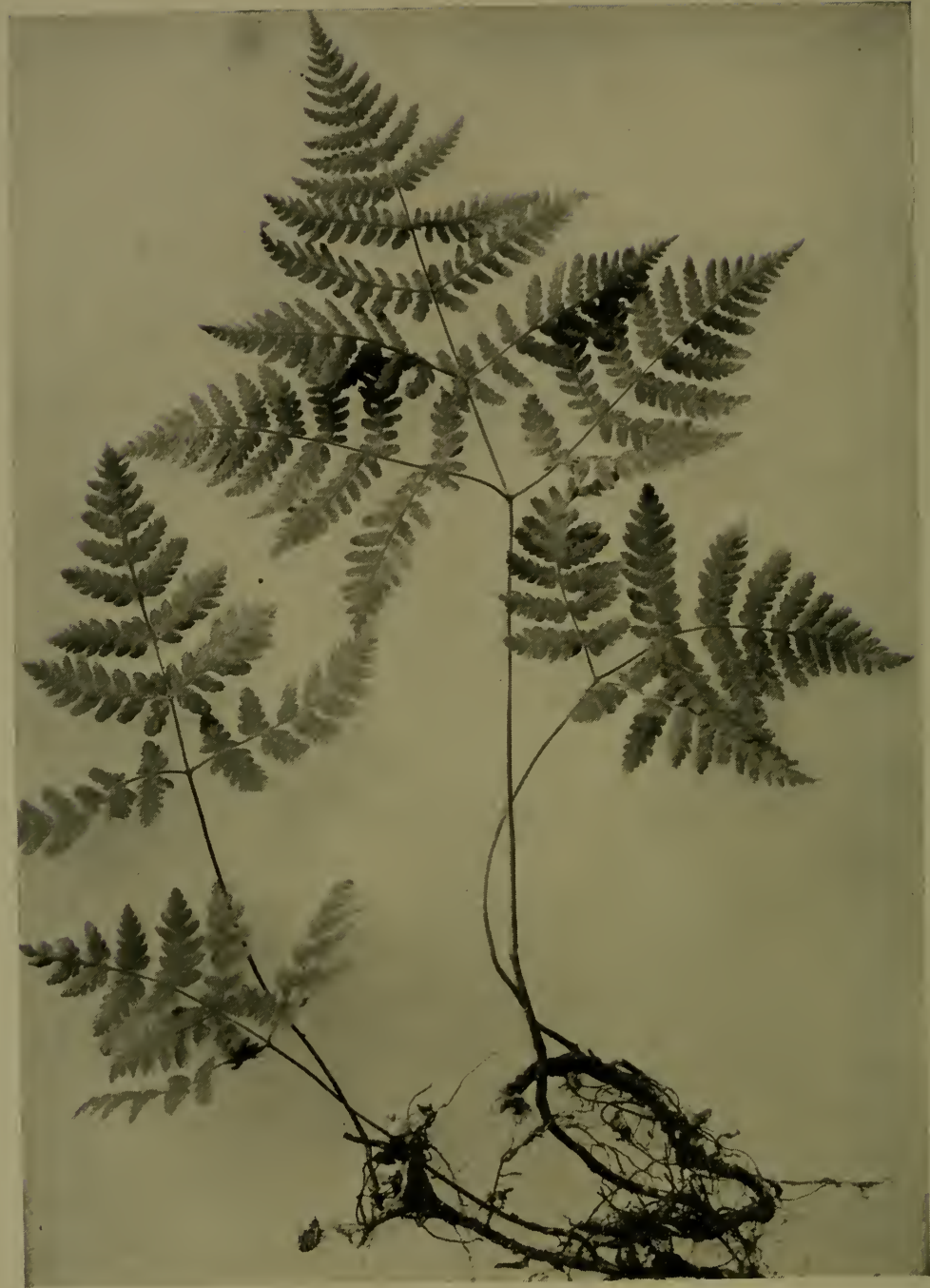

OAK Fern

(Phegopteris Dryopteris) 
were supposed to contain miraculous as well as medicinal properties, and Gadshill in "Henry IV" says:- "IVe have the receipt of fern-seed, we walk invisible." But his faith was quickly dispelled by the answer:- "Nay, I think rather you are more beholden to the night than to fern-seed, for your walking invisible."

\section{MAIDENHAIR}

Adiantum pedatum. Fern Family

Rootstock: slender, creeping, chaffy. Stems: brown, polished, forked at the summit. Leaves: obliquely-orbicular in outline; the pinnules oblong, the terminal one fan-shaped; the lower margin entire; the upper margin cleft, lobed or dentate, bearing the linearoblong sori.

This graceful fern, which is too well-known to need much description, owes its specific name to the fact that the rootstock roots along its whole length. The Maidenhair is usually found in clefts among the rocks near running water, where its fragile, feathery fronds and glistening brown or black stalks are always treasure-trove.

\section{COMMON BRACKEN}

Pteris aquilina, var. lanuginosa. Fern Family

Rootstock: stout, wcody, horizontal. Leaves: usually glabrous, ternate; the upper pinnules undivided; the lower ones more or less pinnatifid.

The most common of all ferns, this Bracken is rather a coarse plant, usually found growing in open woods and sunny places. In the valleys it attains a height of five to six feet, but at high altitudes is much smaller and more delicate. In the spring-time the fronds are always an exquisite pale green, but gradually turn darker and duller of aspect as the season advances. What the origin of the scientific name is, no one 
seems to accurately know. Some say it is derived from a fancied resemblance between the frond and an eagle's wing, while others imagine they can trace the outline of the heraldic eagle in a cross-section of the stalk.

\section{SLENDER LIPFERN}

\section{Chclianthes Féei. Fern Family}

Rootstock: covered with brown scales lined with black. Stems: densely tufted. Leaves: ovate-lanceolate in outline, two-pinnate, with the pinnules pinnatifid, the upper surface tomentose, the lower densely matted with whitish-brown woolly hairs.

A small rock-loving fern, which grows in dense mats, with much-divided leaves, and the fruit dots placed at the ends of the veins.

\section{PURPLE CLIFF BRAKE \\ Pellaa atropurpurca. Fern Family}

Rootstock: short, densely clothed with rusty hair-like scales. Stems: tufted, dark purple, veins obscure, commonly twice-forked. Leaves: coreacious, lanceolate in outline, simply pinnate, or two-pinnate below; rachis brown or purple.

A medium-sized fern, whose distinguishing features are a purple stem, and an undivided leaf bordered by bright brown sporangia. It is usually found growing on limestone rocks, and, unfortunately for the fern-hunter, in very inaccessible places, where the bushy tufts of its greyishgreen foliage flourish in the crannies among the cliffs.

\section{NOOTKA ROCK BRAKE}

\section{Cryptogramma acrostichoides. Fern Family}

Rootstock: stout, chaffy, short. Stems: densely tufted, slender. Leaves: ovate in outline, thin, glabrous, the sterile shorter than the fertile, the margins involute to the midrib at first, expanded at maturity, and exposing the sporanges. 
The two kinds of leaves of this pale green alpine fern are very distinct, the segments of the sterile ones being more cut and much broader than those of the fertile ones, which latter have almost straight margins that are rolled into the centre when the plant is young, and flatten out as it matures, exposing the light brown spore cases with which these fertile leaves are covered. The Nootka Rock Brake was first found by Dr. Archibald Menzies when he came to Vancouver Island with Captain Vancouver in I790.

Cryptogramma Stelleri, or Slender Rock Brake, has a thread-like creeping root, from which the scattered stems grow up at close intervals.

\section{GREEN SPLEENWORT}

\section{Asplenium viride. Fern Family}

Rootstock: stout, creeping, chaffy. Stems: numerous, densely tufted, brownish below, greenish above. Leaves: linear-lanceolate, herbaceous; pinnæ ovate, deeply crenate, unequal sided. Sori: oblong, numerous.

The ancient Greek name of this fern has reference to the fact that it was supposed to be a remedy for certain diseases of the spleen. The leaves are pale green and soft, the upper edges of the pinnæe narrowing suddenly at the base, the lower ones being obliquely truncate, that is having the appearance of being cut off at the top.

Asplenium cyclosorum, or Large Lady Fern, has much bigger and more flaccid leaves than the Green Spleenwort. It is frequently confused with Asplenium Filix-famina, the true Lady Fern, from which, however, it is really quite distinct, the covering of the fruit dots being differently curved. Filix-fomina does not occur in the Rocky Mountains. Of all the ferns which have inspired poets, probably the Lady Fern takes first place, and though the following 
lines by Edwin Lees were really penned to the true Lady Fern, still they are so very quaint and reminiscent of midVictorian verse, that I cannot refrain from appending them to this short note on the Large Lady Fern.

"When in splendour and beauty all nature is crowned, The Fern is seen curling half hid in the ground, But of all the green Brackens that rise by the burn, Commend me alone to the sweet Lady Fern.

Polypodium indented stands stiff on the rock, With his sori exposed to the tempest's rough shock; On the wide, chilly heath Aquilina stands stern, Not once to be named with the sweet Lady Fern.

Filix-mas in a circle lifts up his green fronds, And the Heath Fern delights by the bogs and the ponds; Through their shadowy tufts though with pleasure I turn, The palm must still rest with the fair Lady Fern.

Where the water is pouring forever she sits, And beside her the Ouzel, the Kingfisher flits; There, supreme in her beauty, beside the full urn, In the shade of the rock stands the tall Lady Fern.

Noon burns up the mountain; but here by the fall The Lady Fern flourishes graceful and tall. Hours speed as thoughts rise, without any concern, And float like the spray gliding past the green Fern."

\section{HOLLY FERN}

\section{Polystichum Lonchitis. Fern Family}

Rootstock: short, stout, densely chaffy, bearing large brown scales. Leaves: rigid, leathery, linear-lanceolate in outline, once pinnate, pinnæ broadly lanceolate, scythe-shaped, acute, strongly auricled on the upper side, spinulose-dentate. Sori: biseriate, at length subconfluent.

The Holly Fern has rigid evergreen leaves, each of the pinnæ ending in a sharp point, and having a rounded lobe 
on the upper side at the base, the lower side having an almost straight edge. This fern is densely spiney-toothed.

\section{MALE SHIELD FERN \\ Aspidium Filix-mas. Fern Family}

Rootstock: stout, ascending, chaffy. Leaves: firm, broadly-oblong, lanceolate, acute at the apex. Sori: large, borne near the midvein.

This fern grows in the woods to a height of three feet. It is a handsome plant, springing from an ascending root, and has rather coarse leaves.

Aspidium spinulosum var. dilatatum, or Spinulose Shield Fern, has a stout root, and long, rather thin leaves, the lower pair of which are triangular in outline.

Aspidium Oreopteris, or Scaly Shield Fern, has very scaly, straw-coloured stems and rachis. The leaves are one to two feet long, and taper from near the middle to both ends.

\section{BRITTLE FERN}

Cystopteris fragilis. Fern Family

Rootstock: short. Leaves: thin, oblong-lanceolate, slightly tapering below; pinnæe irregularly pinnatifid, with a broad central space and toothed segments decurrent along the margined or winged rachis, without bulblets.

A delicate, wet-loving fern, which uncurls early in the spring, and soon dies away. It receives its distinguishing name from the stalks, which are slender and very brittle.

Cystopteris montana, or Mountain Bladder Fern, has a slender, widely creeping root, and leaves which are deeply toothed. 
PLATE II

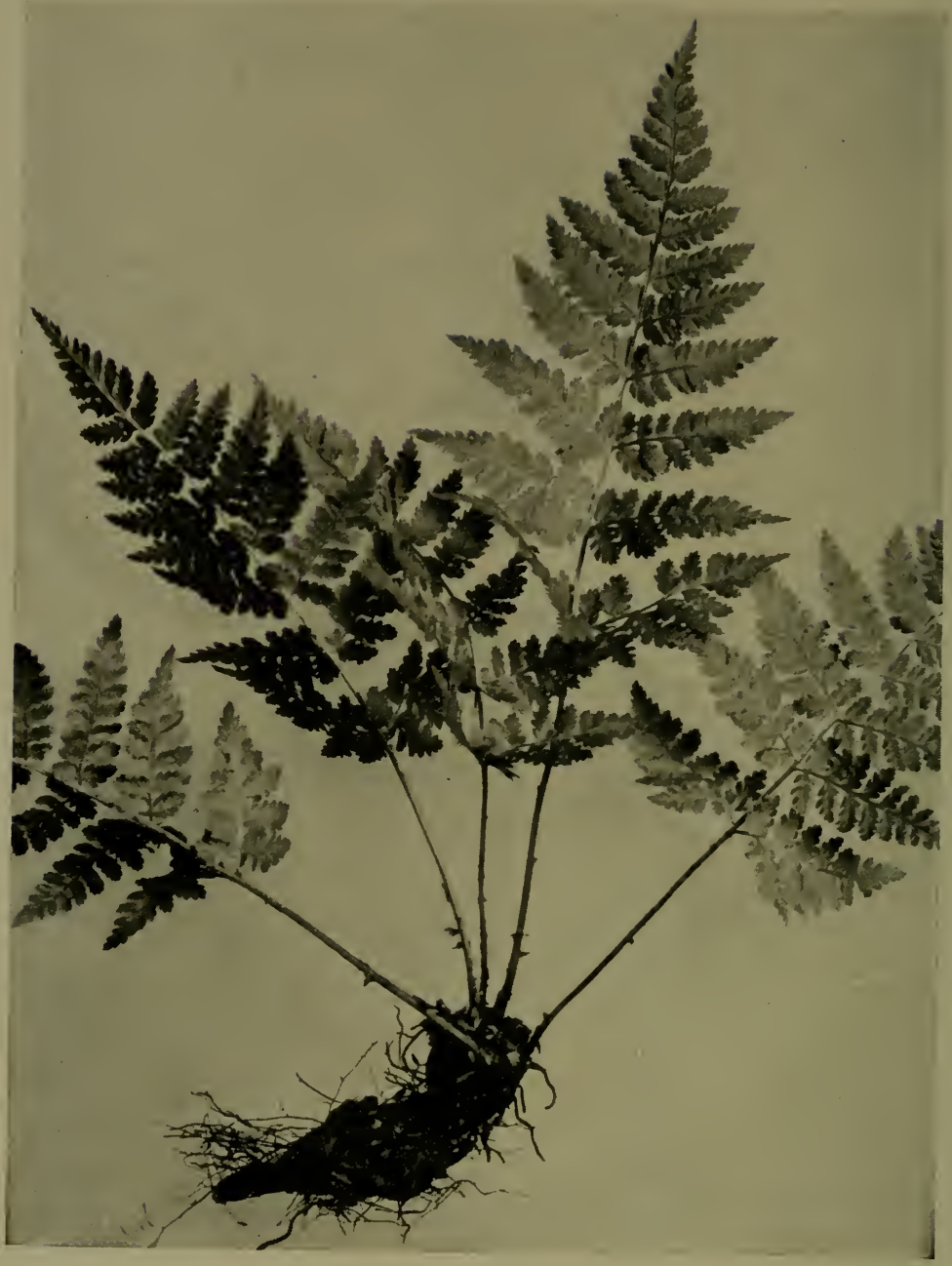

Spinulose Shield Fern

(Aspidium spinulosum var. dilatatum) 


\section{LARGE MOONWORT}

\section{Botrychium Lunaria. Adder's Tongue Family}

Very fleshy. Leaves: the sterile portion borne at, or above the middle of the stem, pinnate, with two to eight pairs of lunate lobes, crenate or entire, fertile portion dense; bud for the following year enclosed in the base of the stem.

The Moonworts are extremely curious plants growing from short, erect rootstocks, and clustered fleshy roots. The name refers to the numerous half-moon-shaped lobes which grow near the middle of the stem on the sterile portion of the plant. Once upon a time, the Moonwort was supposed to possess magic properties, and according to Coles, an old writer on botany, would enable the fortunate owner of the plant to "open the locks wherewith dwellinghouses are made fast, if it be put into the keyhole." Drayton called it "Lunary," and thus refers to its wonderworking power :

"Then sprinkled she the juice of rue With nine drops of the midnight dew From Lunary distilling."

Botrychium simplex, or Small Moonwort, is also called Little Grape Fern, in allusion to its grape-like clusters of spore cases. It is a graceful, variable plant, and has a single lobe on the stem, the fertile portion being a spike with spore cases in rows on either side of its branches.

Botrychium virginianum, or Rattlesnake Fern, is a much larger, and more robust plant, with a much-divided sterile portion, like a fern leaf, its segments more or less toothed.

Botrychium lanccolatum, or Slender Moonwort, has small fronds, and the sterile segment, which is closely sessile at the top of the long slender stalk, is triangular, ternately 
twice pinnatifid, with acute lanceolate lobes that are incised or toothed. The veinlets fork from a continuous midvein.

\section{FIELD HORSETAIL}

Equeistum arvense. Horsetail Family

Stems: annual, hollow, jointed, provided with scattered stomata, the fertile appearing in early spring before the sterile. Leaves: reduced to sheaths at the joints.

This is a rush-like plant of a very rank coarse nature, which grows in ditches and along the sandy waysides. The fertile stems, which appear in the early spring, grow from four to ten inches high and are light brown in colour. They are not branched, but terminate in a solitary cone-like spike. The sterile stems, which appear later on in the season, are green and rather slender, averaging eighteen inches in height. They have numerous verticillate branches, the sheaths of which are four-toothed.

Equisctum pratcnse, or Thicket Horsetail, has many more cup-shaped sheaths on the fertile stems (which become branching when old) than the preceding species; also its branches are more or less horizontal, those of the Field Horsetail growing upwards.

Equisctum sylvaticum, or IVood Horsetail, has furrowed stems, and compound branches; the tiny branchlets curving downwards.

Equisctum scirpoides, or Rush Pipes, has evergreen, perennial, slender, furrowed stems, which grow in tufts from the subterranean rootstock.

Equisctum fuviatile, or Swamp Horsetail, is a large, coarse plant found, as its name denotes, in very wet places. It has a big central cavity in the stem, hollow branches, and a hollow rootstock. 
Equisctum raricgatum, or Varigated Horsetail, has rough, perennial, evergreen stems, growing in tufts, and resembles Rush Pipes, being, however, a much taller plant.

Equisetum hycmale, or Scouring Rush, has stiff, slender stems, and pointed spikes. Its name denotes that it is used by European peasants for scouring floors.

\section{STIFF CLUB MOSS}

\section{Lycopodium annotinum. Club Moss Family}

Stems: much branched, slender, prostrate and creeping, rather stiff, the branches ascending, sparingly forked. Leaves: uniform, spreading, five-ranked, rigid, linear-lanceolate, minutely serrulate, nerved below; spikes solitary at the ends of the branches, oblong-cylindric, composed of ovate bracts, each with a sporange in its axil; spores smooth on the basal surface.

A moss-like herb, with numerous tiny leaves completely covering the short branches, which terminate in dense, oblong spikes composed of small bracts, each one with a sac containing spores in its axil.

Lycopodium clavatum, or Creeping Club Moss, has extensively creeping stems and short, irregular, densely leafy branches. The leaves are much crowded, incurved, and tipped with tiny bristles, and the spikes grow in clusters of from one to four on long peduncles.

Lycopodium Sclago, or Fir Club Moss, has thick, rigid, erect stems, the forked branches forming level-topped clusters.

Lycopodium alpinum, or Alpine Club Moss, has elongated, creeping stems, from which the densely clustered branches rise. The leaves are closely imbricated, and four-ranked, and the spikes solitary at the top of the branches.

Lycopodium sitchense, or Arctic Club Moss, is found at 
high altitudes, like Alpine Club Moss, which it closely resembles.

Lycopodium complanatum, or Trailing Christmas Green, is a most fascinating plant, with fan-shaped branches, which are forked, and covered with minute leaves with somewhat spreading tips; but the chief charm of the Trailing Christmas Green lies in the clusters of upright spikes, borne on long stalks, and which resemble Christmas candles.

\section{SMALL SELAGINELLA}

Selaginella sclaginoides. Selaginella Family

A moss-like plant. Leaves: scale-like, many-ranked, uniform, lanceolate, acute, lax, spreading. Spikes: solitary at the ends of the fertile branches.

This plant has creeping, sterile branches, and erect, fertile ones with tiny, spreading leaves, and large, elongated spikes at their ends.

Sclaginclla rupestris, or Rock Selaginella, has densely tufted stems, stiff imbricated leaves, and quadrangular spikes terminating the branches. 


\section{WILD FLOWERS OF THE NORTH AMERICAN MOUNTAINS}

\section{SECTION II}

\section{TREES}





\section{SECTION II}

\section{TREES}

\section{YEW}

\section{Taxus brevifolia. Yew Family}

A tree twenty to fifty feet high, with slender, spreading or drooping branches. Leaves: flat, mucronate, acuminate, cuspidate, the margins revolute, abruptly narrowed at the base into a short petiole. Fruit: seeds broadly ovate, somewhat flattened.

A beautiful tree with thin bark, and dark red-purple scales, whose long branches are usually horizontal. The leaves are bright yellow-green above, covered with a white bloom beneath, and are persistent for four or five years. The fruit is a lovely red, fleshy cup, containing a black, bony-coated seed.

\section{WHITE-BARK PINE \\ Pinus albicaulis. Pine Family}

An evergreen tree with rather smooth, light-coloured bark. Leaves: slender, rigirl, with a few rows of dorsal stomata on the inside, entire, or nearly so. Flowers: scarlet. Fruit: cones maturing the second year, sessile, horizontal, subtcrminal, oval to globular, purplish-brown; seeds oval, acute, turgid.

This tree grows from twenty to fifty feet high, usually at altitudes between 5,000 and 7,000 feet, and is distinguished by the creany-white, plate-like scales of the bark; very. flexible stout branches; slightly incurved leaves, growing in bundles of five; and horizontal purplish-brown cones 
which grow without any stalk at the ends of the branches. The large, sweet seeds are eaten by the Indians. At very high altitudes this tree is a low shrub with spreading, nearly prostrate branches.

\section{MOUNTAIN PINE}

Pinus monticola. Pine Family

A slender tree fifty to a hundred feet high, and one to six feet in diameter. Leaves: in fives, blue-green, glaucous. Flowers: the staminate ones oval, yellow; the pistillate ones oblong, pale purple. Fruit: pendulous cones with thin scales.

The Mountain Pine is tall and slim, with spreading and somewhat drooping branches. The bark on young trees is pale gray, and on mature trees is divided into square plates covered by small, flat, purple scales. The leaves are deep blue-green, and covered with a lovely bloom; while the long hanging cones are slightly thickened, and smoothed towards the top, and terminate in a small, prickly protuberance.

\section{BULL PINE}

Pinus ponderosa. Pine Family

A tree with massive stem. Leaves: tufted at the ends of naked branches, rigid, in two or three-leaved clusters. Flowers: staminate yellow, pistillate clustered, dark red. Fruit: oval, nearly sessile, three to six inches long, often clustered, green or purple, becoming reddishbrown, the scales armed with slender prickles.

The Bull Pine grows from one hundred and fifty feet to two hundred feet high, and has short thick many-forked branches which are frequently pendulous and turned upward at the ends. The bark is cinnamon-red, brown or nearly black, broken into rounded rilges and covered with appressed scales. On the older trees it is deeply and irregularly divided into plates, and separated into thick reddish 
scales. The leaves are clark yellow-green, and marked by rows of stomata on the three faces. They are from five to eight inches long.

\section{LODGE POLE PINE}

Pinus contorta var. Murrayana. Pine Family

A small, slender tree, with very thin bark. Leaves: delicately serrulate. Fruit: cones oblong-cylindrical, slightly oblique at the base, tapering towards the apex.

The Lodge Pole Pine, often called Black or Jack Pine, is very abundant among the mountains, and may always be recognized by its light orange-brown bark. The branches are spreading below, growing upwards near the top, and forming a pyramidal head; while the leaves are light green, and the small, yellowish-brown cones are oval and shining.

\section{LYALL'S LARCH}

\section{Lari.x Lyallii. Pine Family}

A small tree; branches horizontal and ascending, the branchlets and bud-scales densely pubescent with whitish hairs. Leaves: narrowly linear, without sheaths, in fascicles on short, lateral, scaly budlike branchlets, deciduous. Flowers: in aments, short, lateral, monœcions, staminate from leafless buds, the fertile buds commonly leafy at the base, red. Fruit: cones oblong, promptly deciduous.

Lyall's Larch is a very lovely tree. It is not an evergreen. In September, if you look up to where the conifers greet the edge of the great white nćvés, you will see a zone of glorious flaming yellow foliage adorning the crags and cliffs, and separating the rich green Hemlock, Spruce, Pine, and Fir from the purity of the perpetual snows. This yellow sheen is the autumn dress of the Lyall's Larches; for when the brief alpine summer is past the leaves of these beautiful trees, which grow in clusters out of woody cups, 


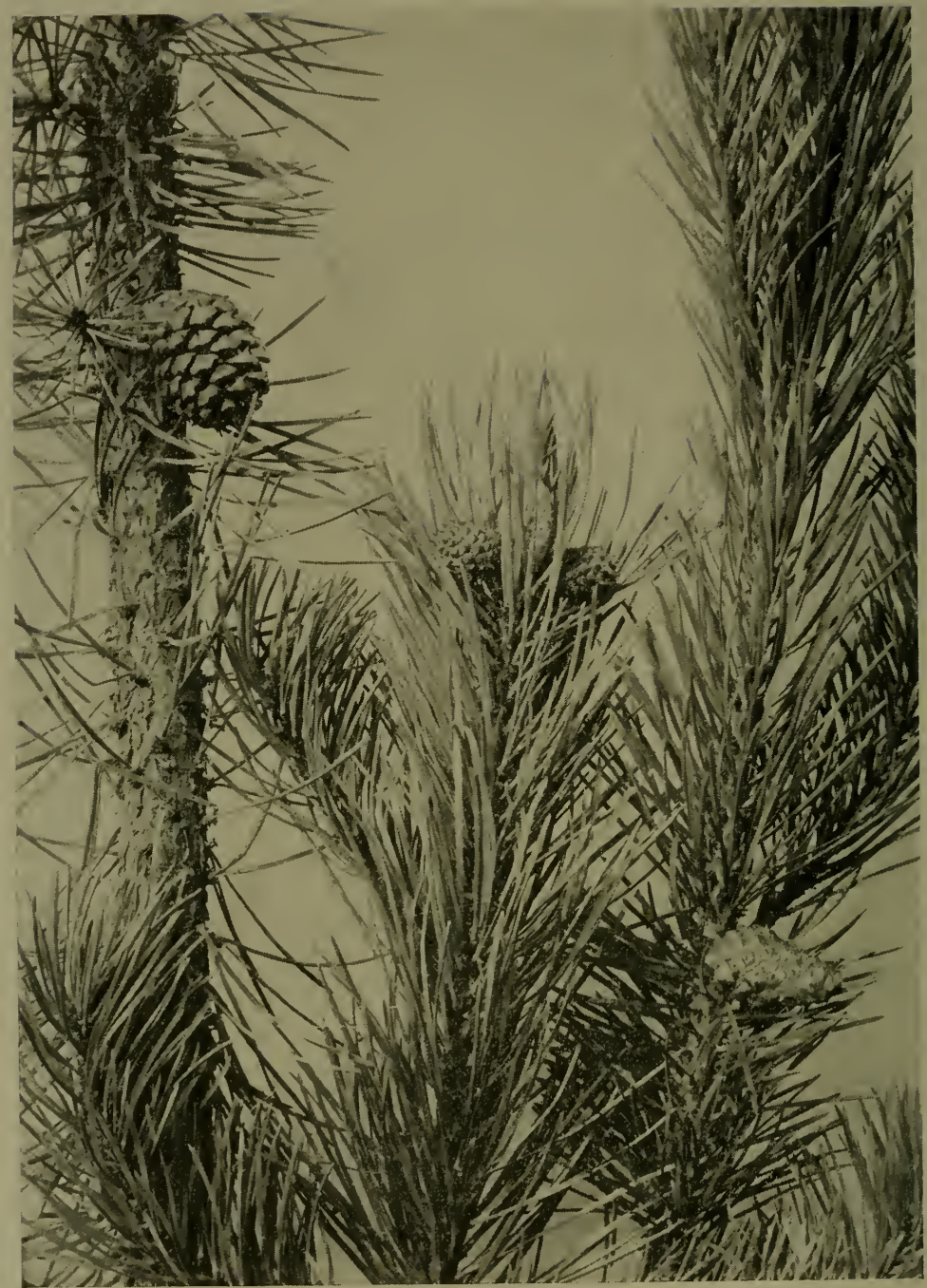

Lodge Pole Pine

(Pinus contorta var. Murrayana) 
and in July are a tender pale green, turn golden-hued before they fall.

The cones are small and dainty and soon drop off. It is very pleasant to pause awhile amongst a grove of these exquisite feathery apple-green Larches, and recall the words of one who said:

"Behind me lay the forests hushed with sleep;

Above me in its granite majesty,

Sphinx-like, the peak thro' silent centuries

Met the eternal question of the sky.

Victor at last - throned on the cragged height -

I scan the grcen steeps $\mathrm{c} f$ the mountain side

Where late I toiled. The forest lands stretch wide,

And in deep valleys farms gleam far and white,

Vistas of distance break upon my sight.

The peopled plain creeps to the sky's blue rim,

Where new peaks gather substanceless and dim,

As half-remembered dreams at noontime light.

“ Between two silences my soul floats still

As any white clond in this sunny air.

No sound of living breaks upon my ear,

No strain of thought - no restless human will -

Only the virgin quiet, everywhere -

Earth never seemed so far, or Heaven so near.

In the awed silence of this dim high place

One kceping vigil might not fear, indeed,

If it befell him as that man of old,

Who in the mountain met God face to face."

\section{WHITE SPRUCE}

Picca canadcusis. Pine Family

A tall tree. Leaves: incurved, acute, terminating in rigid callons tips. Flowers: staminate pale red, soon appearing yellow from the thick covering of pollen. Fruit: cones nearly sessile, pendulous, oblongcylindrical, obtuse at the apex.

The White Spruce has unpleasant-smelling foliage. The branches sweep out in graceful curves, and the tree is pyra- 


\section{PLATE IV}

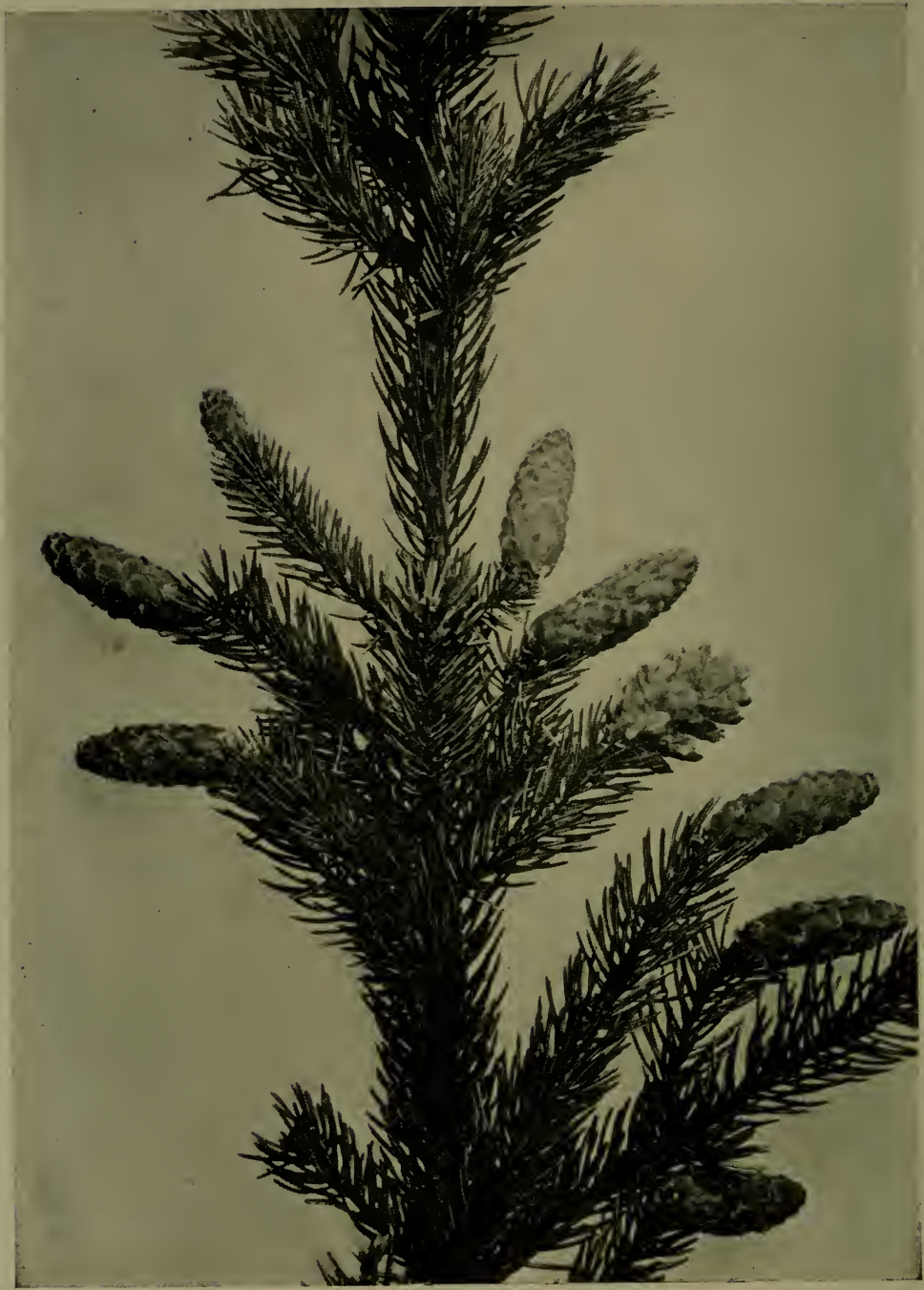

Engelmann's Spruce

(Picea Engelmanni) 
midal in outline. The sharp pointed needles, which are inserted singly, are crowded on the upper side of the branches by the twisting of those on the under side, and are light blue-green or bluish in colour. The pendulous cones are oblong and green tinged with red, becoming pale brown and lustrous at maturity.

\section{ENGELMANN'S SPRUCE}

\section{Picea Engelmanni. Pine Family}

An evergreen tree, fifty to one hundred and fifty feet high, two to five feet in diameter, with spreading branches in regular whorls and pubescent branchlets. Leaves: keeled above and beneath, tretragonal, acute. Flowers: staminate ones dark purple, axillary and terminal on the previous year's branchlets, oblong-cylindrical; pistillate aments bright scarlet, borne at the ends of the branchlets. Fruit: cones pendulous, seeds imbedded in the membranous base of the wing.

Engelmann's Spruce grows between 5,000 and 7,000 feet in the mountains, and is a very disagreeable-smelling tree. It is widely distributed, and has rich cinnamon-coloured bark, and sharp pointed blue-green leaves which are inserted singly and stand out in all directions from the vigorous branches, that grow in whorls round the stem. Many tiny branchlets hang from the main branches. When you take hold of a branch of this tree the leaves feel harsh, and the ends of them will hurt your hand. The drooping cones mature the first year, they are green tinged with reddishpurple, and when mature become a light chestnut brown.

\section{BALSAM FIR}

\section{Abies lasiocarpa. Pine Family}

An evergreen tree fifty to seventy-five feet high. Leaves: those of the main branches linear, rounded or notched at the apex, those of the branchlets flattened, and with long rigid points. Flowers: the staminate indigo-blue, from the axils of the previous year's leaves; the 


\section{PLATE V}

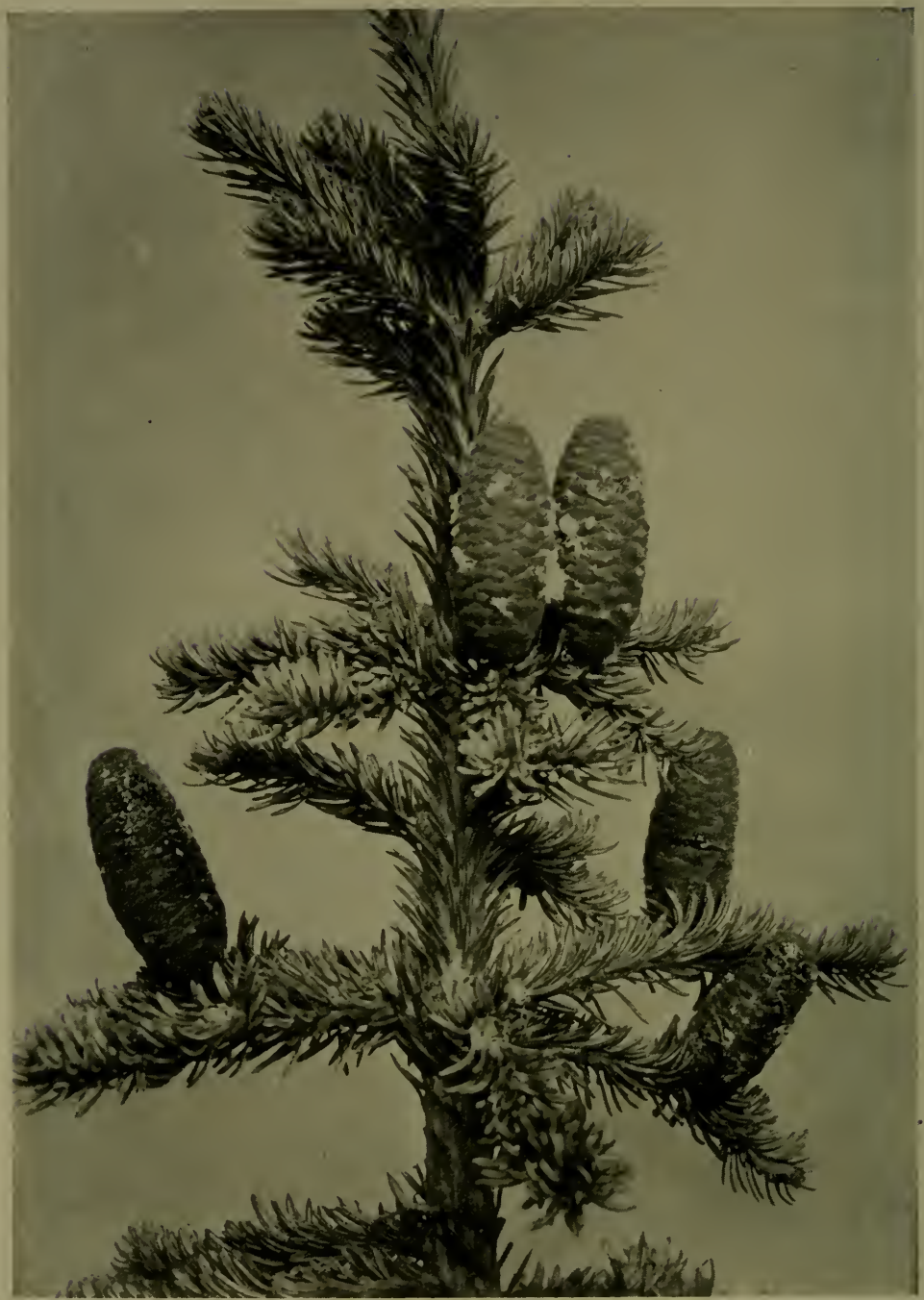

Balsam Fir

(Abics lasiocarpa) 
pistillate with violet, obovate scales, lateral, erect. Fruit: cones erect, cylindrical to ovoid, their broad obtuse scales deciduous from the persistent central axis.

This small conifer has smooth bark divided by shallow fissures somewhat roughened by cinnamon-red scales, and drooping lower branches, the upper ones forming spire-like heads. If you take hold of a branch it feels quite soft in the hand. The needles which are rounded or shallownotched at the apex, are whitish below with a green midrib and the two resin-ducts are imbedded in them. The buds are small, round and gummy.

\section{WESTERN HEMLOCK}

\section{Tsuga helcrophylla. Pine Family}

A tall, evergreen tree. Leaves: flat or somewhat angled, linear, abruptly petioled, entire or spinulose-serrate towards the rounded apex. Flowers: the staminate ones yellow, a subglobose cluster of stamens in the axils of last year's leaves; the pistillate ones terminal on the previous year's branchlets. Fruit: cones pendulous, very small, oblongcylindrical, acute, slightly pubescent.

This tree has reddish-brown bark and conspicuously grooved leaves, which are rounded at the apex, dark green, and very lustrous on the top, and marked below by broad white bands. The foliage has a generally feathery appearance, and the cones are very small.

\section{MOUNTAIN HEMLOCK}

\section{Tsuga Mertensiana. Pine Family}

A large, evergreen tree, with slender pubescent branchlets, and dark green foliage. Leaves: angular, acutish, attenuate at the base, often curved, stomatose and keeled on both sides, unequal, appearing as if in fascicles. Flowers: the staminate ones on very slender drooping stems; the pistillate ones erect. Fruit: cones oblong-cylindrical, large. 


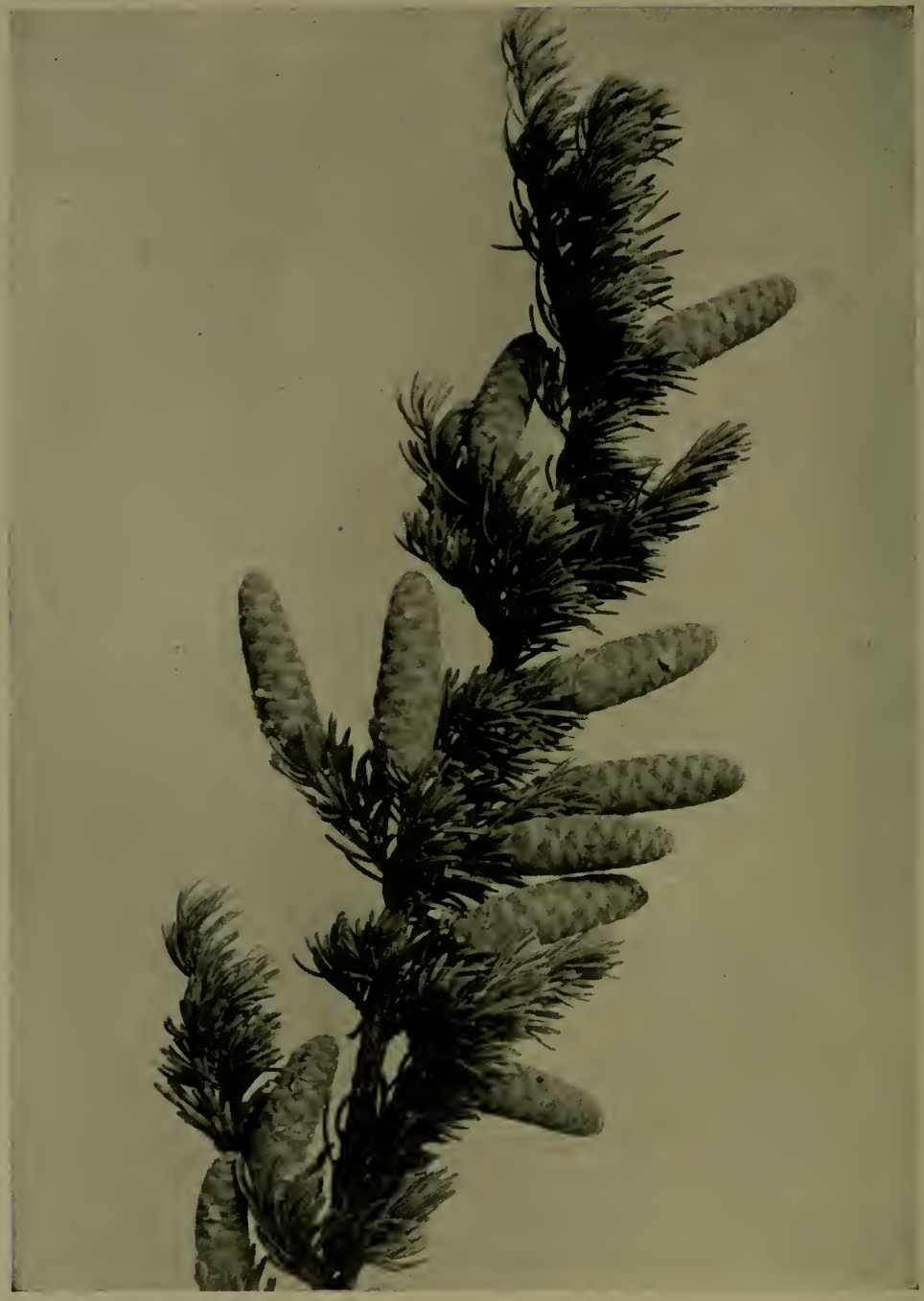

Mountain Hemlock

(Tsuga Mertensiana) 
This Hemlock has leaves, which are bright green both above and below, standing out from all sides of the branches, and cones which are erect when young, and pendulous at maturity.

\section{DOUGLAS FIR}

Pseudotsuga taxifolia. Pine Family

A very large tree, from one hundred to three hundred feet high, two to fifteen feet in diameter. Leaves: linear, obtuse, with two lateral resin-ducts close to the epidermis of the lower side. Flowers: monœcious, from the axils of the previous year's leaves; the staminate ones an oblong column surrounded and partly enclosed by numerous conspicuous bud-scales; the pistillate ones with scales much shorter than the linear, aristate bracts. Fruit: the cones maturing the first year, with persistent scales and exserted bracts.

This grand tree is one of the glories of the forest, with its glossy, crowded leaves, which are rounded at the apex, yellowish-green on the top and have a green midnerve beneath. Its enormous trunk, covered with rough, brown bark, stands up tall and straight like a gigantic ship's mast, while the cones are pendant on long stout stems, and have trident-shaped bracts below the scales.

\section{RED CEDAR}

\section{Thuya plicata. Pine Family}

A tall tree, with thin, fibrous bark, and scattered branches. Leaves: opposite, orate, acuminate, subpungent, adnate, imbricated in four rows. Flowers: terminal, the staminate ones numerous, very small. Fruit: cones maturing the first season, small, soon strongly reflexed.

A tree which grows as high as two hundred and fifty feet, and has very beautiful, shining evergreen foliage. The cones are cinnamon-coloured, and thickly clustered at the ends of the branchlets, the seeds being compressed, and 


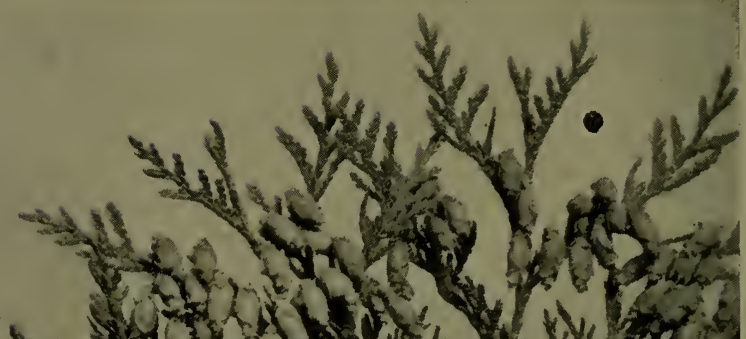

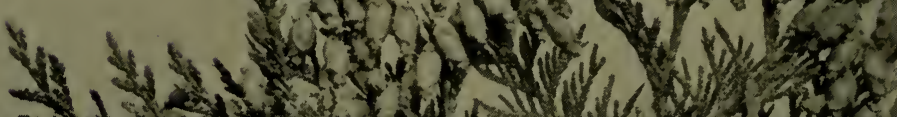

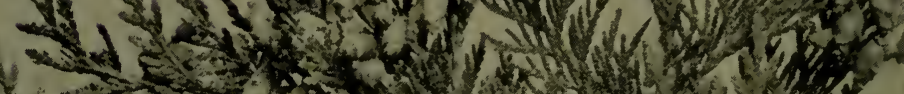
b

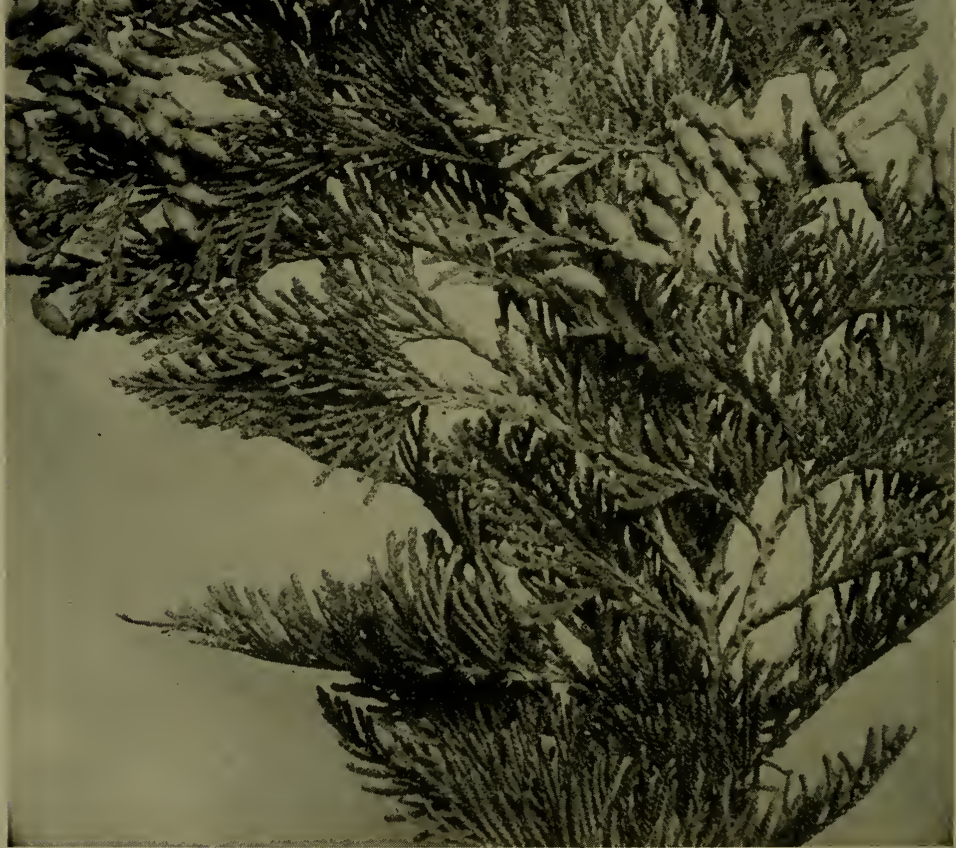

Red Cedar

(Thuya plicata) 
nearly equally winged. The thin bark is bright cinnamonred, and broken on the surface into long narrow loose strips.

\section{ROCKY MOUNTAIN JUNIPER}

\section{Junipcrus scopulorum. Pine Family}

A tree ten to fifty feet high. Leaves: opposite in pairs, spiney-topped, closely appressed, imbricated, four-ranked, acute. Fruit: berry-like cones, glaucous, borne on straight peduncle-like branchlets.

This is the Juniper Tree of the West, whose branches appear quadrangular owing to the flattened manner in which the four-ranked leaves grow on the twigs. The berry-like cones are bright blue, sweet, and covered with a whitish bloom.

Juniperus horizontalis, or Creeping Juniper, is a depressed, and usually procumbent shrub, seldom growing more than three feet high. Its leaves are similar to those of the Rocky Mountain Juniper, and its fruit is a blue berry-like cone, containing one to four seeds, whereas the preceding species is only one to two seeded.

Juniperus communis var. montana, or Alpine Juniper, is a very depressed, almost prostrate species of Juniper, which forms on the ground large circular patches that sometimes extend to ten feet in diameter. It grows at extremely high altitudes, and is one of the last signs of vegetation encountered near the tree-line. The leaves, which densely cover the branches, are channelled, and sometimes whitened on the surface; they are set in verticils of three on the twigs. The cones are berry-like, being rounded, smooth, and dark blue.

\section{HOARY WILLOW}

Sali.x candida. Willow Family

An erect shrub. Leaves: persistently white-tomentose beneath, green and loosely tomentose above, oblong-lanceolate, thick, sparingly dentate 
or entire, acute at both ends. Flowers: aments expanding before the leaves, cylindric. Fruit: a capsule, ovoid-conic, acute, densely tomentose.

The pointed leaves of the Hoary Willow are extremely white-woolly, especially beneath, and the red style is three times as long as the stigmas. The older twigs of this shrub, which attains a height of five or six feet, are red or purple, and the younger ones are white-woolly like the leaves.

Salix Barclayi, or Barclay's Willow, has dark brown twigs, and oval leaves, which are a pale green beneath, and darker on the top. Sometimes you will find on this Willow a number of curious rose-like arrangements terminating the branches, these are the result of the work of a species of gall insect and look exactly like reddish-green roses.

Salix Barrattiana, or Barratt's Willow, is a small tree growing from ten to fifty feet high, with light gray bark, and oblong, dark green leaves, which become rusty beneath when old. The aments are very densely-flowered, the scales being black or red at the apex, and woolly with long white hairs.

Salix Bebbiana, or Brown Willow, is sometimes a shrub, and sometimes a bushy tree twenty-five feet high. It has elliptical, pointed, gray-green leaves, often tinged with red on the upper surface, and woolly underneath.

Salix nivalis, or Alpine Willow, is a small species growing very high up on the mountains.

Salix petrophila, or Dwarf Willow, is a low creeping shrub, with narrow leaves about an inch long, which have even edges, and are green on both sides. It grows at very high altitudes.

Salix vestita, or Hairy Willow, is a low shrub with foursided green twigs, and thick, egg-shaped leaves, which have 
slightly wavy margins dark green and smooth on the top, and silky underneath. The amerts are stalked, and the capsules are densely silky-hairy.

Salix sitchensis, or Sitka Willow, is a straggling shrub, or a much-branched tree, with reddish-brown bark, slender, downy branches, and leaves which are dark green above, and thickly covered beneath with lustrous satiny hairs.

Salix arctica, or Arctic Willow, is a low branching shrub, with egg-shaped leaves narrowed at the base, and growing on long leaf-stalks.

\section{ASPEN POPLAR}

\section{Populus tremuloides. Poplar Family}

A slender tree with thin, yellowish-brown or pale bark. Leaves: ovate, short-acuminate at the apex, finely crentulate, rounded or subcordate at the base. Flowers: Aments drooping, dense. Fruit: capsule conic, acute, papillose.

The Aspen Poplar is one of the prettiest trees among the mountains, and when the wind blows its tiny heart-shaped leaves, growing on very slender little stalks, tremble with a soft rattling sound. The flowers grow in rather stout catkins.

Populus balsamifcra, or Balm of Gilead, has leaves rounded at the base and pointed at the apex, finely toothed, and with slightly revolute margins, that are dark green above and pale green and somewhat rusty below. This tree grows to a hundred feet in height, has stout erect branches, more or less contorted towards the ends, and brown bark tinged with red, which on older trunks becomes greyish and divided into broad ridges covered with closely appressed scales.

Populus trichocarpa, or Western Balsam Poplar, has smooth ashy-grey bark, and stout upright spreading branches. The large buds are very fragrant and resinous, 
and the leaves, which grow on long stalks, are egg-shaped, finely toothed, dark green on the top and quite pale beneath. The catkins are slender.

Populus acuminata, or Cottonwood, is a much smaller tree than the preceding species. It has stout spreading ascending branches forming a rounded head, very pointed leaves which are toothed except near the apex and base, and pale grey-brown bark divided into broad flat ridges. The bark on the young stems and the branches is smooth and nearly white.

\section{BLACK BIRCH}

\section{Betula fontinalis. Birch Family}

A tree with smooth bronze bark. Leaves: broadly ovate, acute, sharply serrate except at the rounded subcordate and often unequal base. Flowers: staminate aments clustered with light brown scales, pistillate aments short-stalked, with ovate acute green scales. Fruit: strobiles cylindrical, puberulous, erect or pendulous on slender stalks.

The Black Birch is a small tree with slender spreading pendulous branches and lustrous copper or bronze bark. The leaves are broad, and pointed at the apex, pale green above, and yellowish with minute glandular dots below, their short stems often slightly reddened, and they turn completely yellow in the autumn before falling.

Betula alba var. papyrifera, or Paper Birch, is a large forest tree, with outer lustrous white bark peeling off in thin layers, and disclosing the inner orange surface. The leaves are ovate, very pointed, also coarsely double-toothed all round, and rounded at the base.

Betula glandulosa, or Dwarf Birch, is a small shrub growing from one to five feet high, or procumbent at high altitudes, with glandular, warty twigs, and rounded leaves, bluntly toothed. 


\section{MOUNTAIN ALDER}

Alnus sinuata. Birch Family

A small tree or shrub. Leaves: ovate, acuminate, obtuse or crenate at the base. Flowers: aments of both kinds on long, slender peduncles.

The Mountain Alder has rather dark bark, and bright green leaves, which are doubly toothed, thin, and very gummy when young. The staminate aments are pendulous, like catkins, and the pistillate ones are rounded and erect.

Alnus sitchcnsis, or Speckled Alder, has brown bark, and broacler leaves than the preceding species, these leaves are acutely doubly-toothed, light green on both sides, and speckled with white. This tree grows in wet places.

\section{WESTERN MOUNTAIN ASH \\ Pyrus sambucifolia. Rose Family}

Leaves: alternate, pinnate; leaflets seven to fifteen, lanceolate, shortpointed at the apex, sharply serrate, glabrous and dark green above, pale and more or less pubescent beneath. Flowers: white, in terminal compound cymes; calyx-tube urn-shaped, five-lobed, not bracteolate; petals five, spreading, short-clawed. Fruit: a small, red, berry-like pome, bitter.

This is the Rowan Tree of the mountain regions, and a very handsome shrub or tree it is, sometimes attaining a height of twenty feet, but usually growing only from six to fifteen feet high.

The leaves are dark green on the top and a much paler hue beneath. The flower-buds are a delicate shade of creamy pink, and turn white when they expand in the sunshine, the wide-open blossoms having a darkened appearance in their centres, caused by the numerous stamens. This shrub is found at great altitucles, growing close to the edge of perpetual snow and bearing quantities of splendid foliage and huge clustered cymes of soft-tinted flowers, which diffuse an extremely pungent odour. 
The Rowan Tree is famed in verse and legend, but surely no tenderer poem was eve- penned in its honour than the old immortal song:

"O Rowan tree! O Rowan tree! thou' 'lt aye be dear to me; Entwined thou art wi' mony ties o' hame and infancy. Thy leaves were aye the first o' spring, thy flowers the simmer's pride; There was nae sic a bonnie tree in a' the countrie side,

O Rowan tree!

"How fair wert thou in simmer time, wi' a' thy clusters white! How rich and gay thy autumn dress, wi' berries red and bright! We sat aneath thy spreading shade; the bairnies round thee ran; They pu'd thy bonnie berries red, and necklaces they strang,

O Rowan tree!"

\section{WESTERN CHOKE CHERRY}

\section{Prunus demissa. Rose Family}

A small tree or shrub, attaining a height of thirty feet, but usually smaller. Leaves: obovate, thick, acute at the apex, shori-serrate. Flowers: racemes densely-flowered, terminating leafly branches. Fruit: a drupe, globose, stone globular.

This Cherry has long-shaped clusters of small white flowers at the ends of the leafy branches, and the edible fruit is fleshy, dark purple, and sweet, but slightly astringent, the seed containing prussic acid.

\section{DWARF MAPLE}

\section{Acer glabrum. Maple Family}

A small tree or shrub, with a maximum height of thirty-five feet. Leaves: opposite, simple, palmately lobed, the lobes acute, sharply serrate. Flowers: in numerous small, lateral and terminal sessile, corymblike racemes. Fruit: of two long-winged samaras, joined at the base, one seeded, glabrous, shining, little diverging.

This is the Maple of the mountains, and has lovely foliage, greenish-yellow flowers, and quantities of long-winged fruit. 


\title{
WILD FLOWERS OF THE NORTH AMERICAN MOUNTAINS
}

\author{
SECTION III
}

REEDS, GRASSES, SEDGES AND RUSHES 



\section{SECTION III \\ REEDS, GRASSES, SEDGES AND RUSHES}

\section{BROAD-LEAVED CAT-TAIL}

Typha latifolia. Cat-tail Family

Stems: stout. Leaves: nearly equalining or exceeding the stems, linear, flat, ensiform, with sheathing base. Flowers: very numerous in dense, terminal spikes. Fruit: nut-like, small, usually splitting on one side.

A common marsh plant, with long, ribbon-like leaves, and a tall stem surmounted by a dense, dark-brown flower spike. The old Italian Masters frequently painted the Cat-tail in the hand of the Saviour as a mock-sceptre in their pictures of the Crowning of the Christ with Thorns. It is often confused with the Bulrush (Scirpus).

\section{SIMPLE-STEMMED BUR-REED \\ Sparganium simplex. Bur-Reed Family}

Stems: erect or floating. Leaves: more or less triquetrons, linear, alternate. Flowers: densely crowded in blobose heads at the upper part of the stem. Fruit: nut-like, one-celled.

In bogs, and at the edge of mountain ponds and streams, this common Bur-reed is very abundant. It may readily be recognized, so perfectly does its name describe its two chief characteristics, namely its bur-like brownish flower-heads, and reed-like stems. 


\section{MARSH ARROW GRASS}

\section{Triglochin palustris. Arrow-grass Family}

A marsh herb. Rootstock: short, oblique, with slender, fugacious stolons. Leaves: linear, shorter than the scapes. Flowers: in racemes, perianth herbaceous, of three concave sepals and three petals. Fruit: linear or clavate.

A marsh plant, with narrow leaves tapering to a point, and greenish-yellow flowers growing in a long-shaped head.

\section{ALPINE TIMOTHY}

Phleum alpinum. Grass Family

Clum: glabrous, erect, simple, sheaths often much shorter than the internodes, sometimes longer. Leaves: smooth beneath, scabrous above. Spike: short, ovoid to oblong, cylindric.

A perennial grass, with flat leaves, and numerous dense, one-flowered spikelets.

Calamagrostis canadensis, or Blue-joint Grass, has flat leaves, and open panicles of a purplish colour. It grows principally in wet meadows.

Poa alpina, or Alpine Spear Grass, has short, pointed leaves, and panicles from one to three inches in length.

Festuca ovina, or Sheep's Fescue Grass, grows in a tufted fashion, and has thread-like leaves growing from the base of the plant, its panicles being often one-sided and flattened. It is abundant in dry meadows, and rocky places.

Bromus Richardsonii, or Fringed Brome Grass, resembles oats, and has wide leaves which are smooth beneath, and rough on the top. The panicle is composed of many branches, each one terminating in spreading or drooping spikelets, with tiny awns.

Hordeum jubatum, or Squirrel-tail Grass, is one of the handsomest and most remarkable grasses in mountain re- 
gions. The spikelets with their slender, rough awns from an inch to two and a half inches long, resemble barbs, and these awns turn to a warm, rich reddish hue as the summer advances, and present a beautiful appearance as they swing and sway in the wind.

"In the summer of the summer, when the hazy air is sweet

With the breath of crimson clover, and the day's a-shine with heat, When the sky is blue and burning and the clouds a downy mass, When the breeze is idly dawdling, there is music in the grass -

"Just a thistly, whistly sound

In the tangles near the ground;

And the flitting fairies often stop to listen as they pass;

Just a lisping, whisp'ring tune,

Like a bumblebee's bassoon,

In a far-away fantasia, is the music in the grass.

"Would you know what makes the music? On each slender, quivering blade

There are notes and chords and phrases by the bees and crickets played;

And the grasshoppers and locusts strive each other to surpass

In their brave interpretation of the music in the grass.

"By the roguish breezes tost

You might think it would get lost,

But the careful fairies guard it, watching closely as they pass.

So on every summer day,

Sounding faint and far away,

Is the mystic, murmuring marvel of the music in the grass."

\section{HARE'S TAIL}

Eriophorum callitrix. Sedge Family

Perennial by rootstock. Culm: obtusely triangular, stiff, smooth, slender. Leaves: filiform, channeled; spikelet terminal, solitary, erect; involucre none; scales spirally imbricated, ovate-lanceolate, long-acuminate, purplish-brown, membranous; bristles numerous, white or slightly yellowish, weak. 


\section{PLATE VIII}

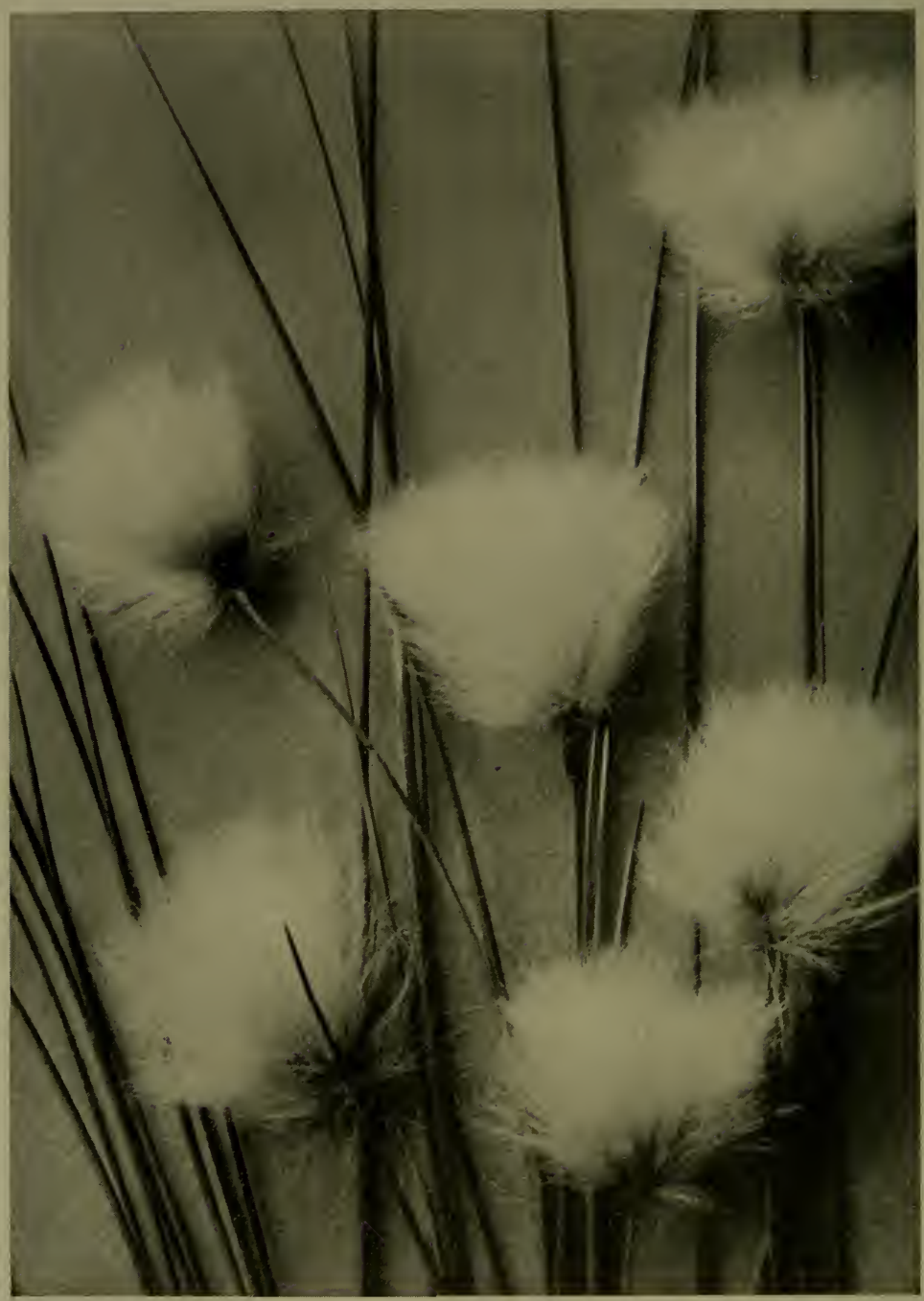

Hare's TAIL

(Eriophorum callitrix) 
Close beside the margins of the alpine lakes and streams may this soft fluffy-headed Sedge be found. It has a tall culm, two or three slender channelled leaves, and a single terminal white or cream-coloured head composed of fine silky bristles.

Eriophorum angustifolium, or Cotton Grass, has very narrow leaves, and is a smaller, more delicate plant than the preceding species.

\section{ARCTIC KOBRESIA}

Kobresia bipartita. Sedge Family

Culms: solitary or tufted, smooth. Leaves: unfolded, shorter than the culm. Spike: composed of several linear, appressed or ascending spikelets. Fruit: achenes sessile.

This slender mountain Sedge has a number of short, narrow leaves, and flowers growing in a terminal spike. A very common plant.

Kobresia Bellardi, or Arctic Elyna, is more densely tufted than the preceding species, and the margins of the leaves are revolute.

\section{TUSSOCK SEDGE}

Carex festiva. Sedge Family

Stems: triangular. Leaves: the upper longest, commonly shorter than the stem. Heads: dark, ferruginous, spikes ovoid, contiguous in an oblong or crowded spherical cluster.

These grass-like Sedges are extremely numerous. The Tussock Sedge has brown-purple spikes, and rough-margined leaves.

Carex pyrcnaica, or Dwarf Sedge, is a small species, very leafy at the base, and densely-flowered. It grows at high altitudes.

Carex Mertensii, or Merten's Sedge, has slender, erect 
stems, which are rough on the very sharp angles. The leaves are broad and flat, and the spikes drooping on slim stalks. It grows at the edge of high mountain streams.

Carex nigricans, or Black Sedge, is leafy at the base, the leaves terminating in very sharp points. The spikes are almost black. It grows in wet meadows at high elevations.

Carex rupestris, or Rock Sedge, has leaves which often curve and curl, and a solitary, terminal spike.

\section{ALPINE BOG RUSH}

\section{Juncus Mertensianus. Rush Family}

Stems: weak from matted rootstock. Leaves: ligule, conspicuous. Flowers: a solitary, many-flowered head, perianth segments dark brown, ovate-lanceolate, the outer ones aristate-acuminate. Fruit: many-seeded, apiculate at each end.

A swamp plant, with long, grass-like leaves, and a single, many-flowered head, which is found in wet meadows on high mountains. The pith from the stems of the Juncus was formerly used as wicks for the old-fashioned " rushlights."

Juncus triglumis, or Three-flowered Bog Rush, has all basal leaves with clasping sheaths, the blades short and blunt. The three-flowered head grows at the top of the stem.

Juncus Drummondii, or Drummond's Bog Rush, has very slender tall stems, and sheathing leaves. The panicle is greenish-brown.

Juncus Parryi, or Parry's Bog Rush, grows from three to ten inches high, and has inner leaf-bearing sheaths. The leaves are grooved at the base, and much shorter than the stems; while the panicle of inconspicuous blossoms is looselyflowered, the floral leaves being tinged with brown. 


\section{SMALL-FLOWERED WOOD RUSH}

Luzula parviflora. Rush Family

Stems: single or few in a tuft, stoloniferous, erect. Leaves: glabrous. Flowers: borne singly or sometimes two or three together on the branches of the inflorescence on slender pedicels. Fruit: seeds narrowly oblong.

A perennial plant, with leaves tapering to a sharp point, and a nodding, decompound, greenish-brown panicle. The Wood Rushes are rather degenerate, as the scentless, honeyless, colourless condition of their tiny blossoms evidences, and they depend altogether upon wind-fertilisation.

Luzula spicata, or Spiked Wood Rush, has from one to three grass-like leaves on the stems, and a nodding spikelike panicle. 



\title{
WILD FLOWERS OF THE NORTH AMERICAN MIOUNTAINS
}

\author{
SECTION IV
}

\section{WHITE TO GREEN AND BROWN FLOWERS}





\section{WHITE TO GREEN AND BROWN FLOWERS}

\section{RICHARDSON'S PONDWEED}

\section{Potamogeton Richardsonii. Pondweed Family}

A marsh herb. Stems: slender, much branched. Leaves: obtuse to acute, curved inward at the apex, broadly cordate and clasping at the base. Flowers: small, spicate, green or rarely reddish. Fruit: drupelets, obliquely obovoid, obscurely three-carinate on the back, the face curved outwardly towards the top.

This Pondweed, which flourishes in lakes and streams, frequently flowers and fruits under water; its large leaves, heart-shaped at the base, being practically all submerged.

Potamogeton filiformis, or Filiform Pondweed, has numerous very narrow leaves, and flowers which grow in tiny whorls near the top of the slender stems.

\section{GLUTINOUS ASPHODEL}

Tofieldia glutinosa. Lily Family

Stems: viscid-pubescent with black glands, bearing two to four leaves near the base. Leaves: basal ones tufted. Flowers: terminal racemes oblong, the upper flowers opening first, becoming longer in fruit; involucral bracts minute, united at the apices, borne just below the flower: perianth-segments oblong, obtuse, membranous. Fruit: seeds tailed at each end.

A traveller cannot pick the long spikes of tiny white blossoms which belong to this plant without at once recognizing its name by the exceedingly sticky and hairy nature of the stems, The Latin designation glutinosa exactly describes 
it. The Asphodel grows along the banks of streams and in wet places.

Toficldia palustris, or Scottish Asphodel, has leafless stems and tufted leaves. The greenish-white flowers grow in a dense oblong cluster.

Tofieldia occidentalis, or Western Asphodel, has a stout stem one to three feet high and long leaves. It is found in marshy places.

\section{BRONZE BELLS}

\section{Stenanthium occidentale. Lily Family}

Bulb: oblong-oroid, coated. Stems: slender, erect, glabrous. Leaves: few, linear, lanceolate, acuminate. Flowers: raceme simple, flowers campanulate, nodding, segments of the perianth brownish-green; bracts somewhat scarious; pedicels slender, spreading, longer than the bracts. Fruit: seeds linear, flat, winged.

This plant grows only in shady places and is tall, with many brownish-green bells nodding on its slender stalks. It has very narrow ribbon-like leaves growing from the base and also up the stems.

\section{GREEN LILY}

Zygadenus clegans. Lily Family

Bulb: ovoid, membranous, coated. Stems: slender. Leaves: very glaucous, narrow; bracts long-keeled, lanceolate, rather large. Flowers. in a single raceme, or a large panicle, its branches slender, ascending, the perianth adnate to the base of the ovary, its segments broadly oval, the inner abruptly contracted to a short claw, gland obcordate. Fruit: seeds oblong, angular.

A tall attractive plant whose branching stems are covered by many round creamy flowers splashed with green. These flowers are six-parted and have a number of brown-tipped stamens clustered about the large green base of the pistil. The capsule, or dry fruit, which develops as the floral leaves 
PLATE IX

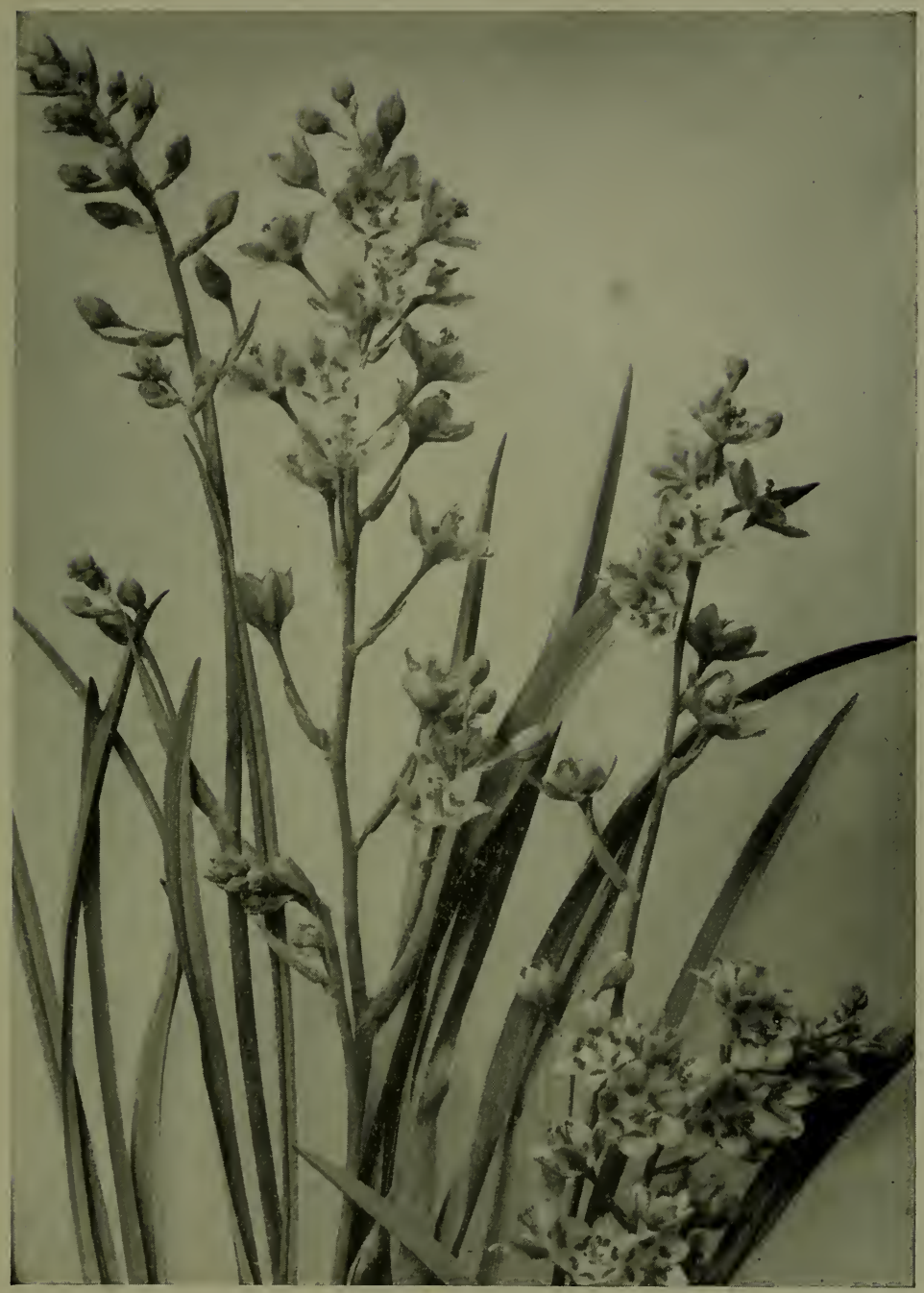

Green LiLy

(Zygadenus elegans) 
die and drop off, is three-lobed and very large. The leaves of the Green Lily are long and narrow and are covered with a whitish bloom.

Zygadenus renenosus, or Poisonous Green Lily, is a slightly shorter, smaller species of this genus, also frequently found in the mountain regions. Its yellowish-green flowers grow closely together and it has roughish leaves. So poisonous is this plant that animals frequently die from the effects of eating it.

\section{INDIAN HELLEBORE}

Veratrum viride. Lily Family

Stems: stout, tall, very leafy. Leaves: acute, strongly veined, shortpetioled, sheathing, the upper ones successively narrower, those of the inflorescence small. Flowers: panicles long, pubescent, densely manyflowered, its lower branches spreading.

This is by far the largest and handsomest green-flowered plant which grows in the mountains. Its foliage is immense in size, bright green, and the leaves have a peculiar plaited appearance. In the early spring the stout solid spears of the Indian Hellebore push their way up through the soil and soon begin to unfold with the increasing warmth of the sun's rays. Then the long stiff spikes and graceful pendent tassels of flowers commence to lengthen and unfold, yellowish at first, and later on becoming greener. The flowers are composed of six petals and have six whitish stamens.

Burton in his Anatonic of Mclancholy refers to the alleged curative properties of the Hellebore as an anticlote for madness.

"Borage and hellebore fill two scenes, Sovereign plants to purge the veins Of melancholy, and cheer the heart Of those black fumes which make it smart." 


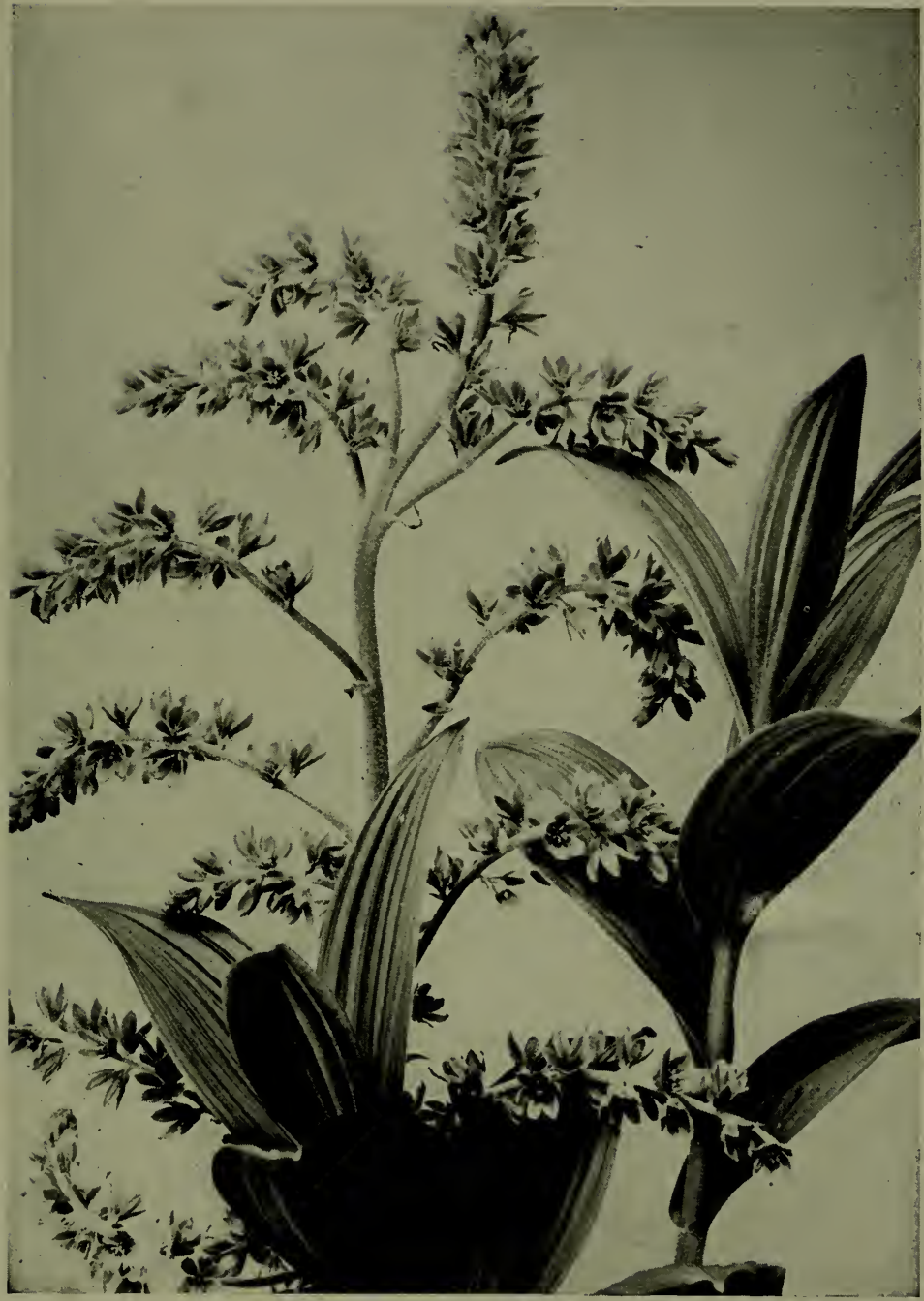

INDIAN HELLEBORE

(Veratrum viride) 
Yet according to the principle that those herbs which cure may also kill, the Hellebore is best known to us as a very poisonous plant.

\section{MOUNTAIN ADDER'S TONGUE}

\section{Erythronium montanum. Lily Family}

Stems: scale slender, six to eighteen inches high. Leaves: broadly lanceolate to ovate. Flowers: perianth broadly funnelform, of six distinct broadly lanceolate segments, slenderly acuminate, the inner ones with small teeth at base. Fruit: capsule membranaceous, obtusely triangular, seeds in two rows in each cell, ascending, with brown or black rugulose testa somewhat loose at the apex.

This Adder's Tongue has lovely white flowers, the segments of the perianth being more or less revolute, and orange at the base. The leaves are pale green, and not mottled, they are oval and abruptly contracted at the base into a winged petiole. One to three flowers grow on the slender stalks that are six to twelve inches high.

\section{GREEN-BANDED MARIPOSA}

Calochortus macrocarpus. Lily Family

Stems: stout, erect, rigid. Leaves: radical, solitary, deeply channeled, cauline narrow, convolute. Flowers: sepals lanceolate, acuminate, petals cuneate-obovate. Fruit: capsule lanceolate, attenuate, upward, seeds numerous.

The Green-banded Mariposa is a very beautiful perennial lily, with one or more flowers growing on a stiff erect stem, and the single long basal leaf being deeply channeled. The three narrow pointed sepals are purplish-green with a dark base inside, sometimes spotted and hairy, and the three broad, more or less concave petals are pale lilac with a greenish line down the centre. The gland is oblong and densely hairy. This lily grows in very dry places. Its large bulbs 


\section{PLATE XI}

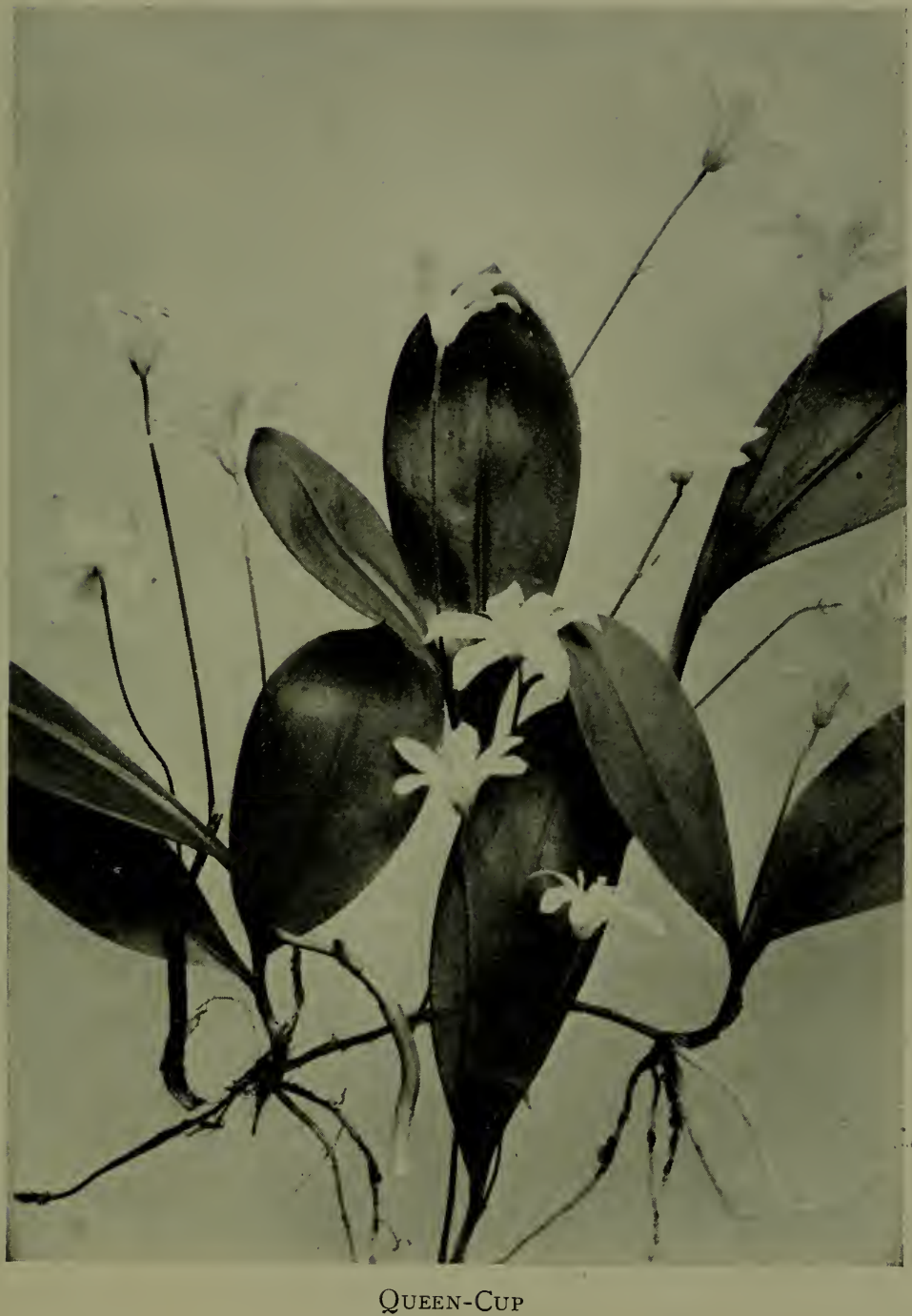

(Clintonia uniflora) 
are considered a great delicacy by the Indians, who call them noonas.

Calochortus Lyallii, or Pale Mariposa, grows on the grassy slopes of high mountains. It has a slender stem bearing three to five flowers in an umbel, each blossom composed of three greenish-purple sepals strongly arched below, the pit thus formed being dark purple inside, and the three white, or pale yellow petals, having a purplish base and being also arched below.

\section{QUEEN-CUP}

Clintonia uniflora. Lily Family

Stems: villous-pubescent. Leaves: few, lanceolate, acute, attenuate below to a sheathing petiole. Flowers: solitary, peduncle scape-like, shorter than the leaves; perianth campanulate, of six segments, white; style equalling the stamens. Fruit: blue berry.

An exquisite six-parted white flower with a heart of gold, found growing in the shady woods. Its leaves fairly carpet the ground in the localities where it abounds; they are large and glossy and resemble those of the Lily-of-the-Valley. The stems, which usually bear only a single flower, are very hairy. Thoreau has complained bitterly that this beautiful dweller of the forest should be called after so prosaic an individual as the Governor of New York, and soundly berates Gray for the fault; but may not Clinton, the man of affairs, statecraft, and finance, have had an artistic side to his character? May he not have been a true lover of Nature and an ardent admirer of the splendid beauties that enrich with the perfume of their presence the land of the alpine flower-fields?

I feel that a great honour has been conferred upon me in that I have been permitted to name this lovely plant Queen-cup. Hitherto it has been nameless in the English 


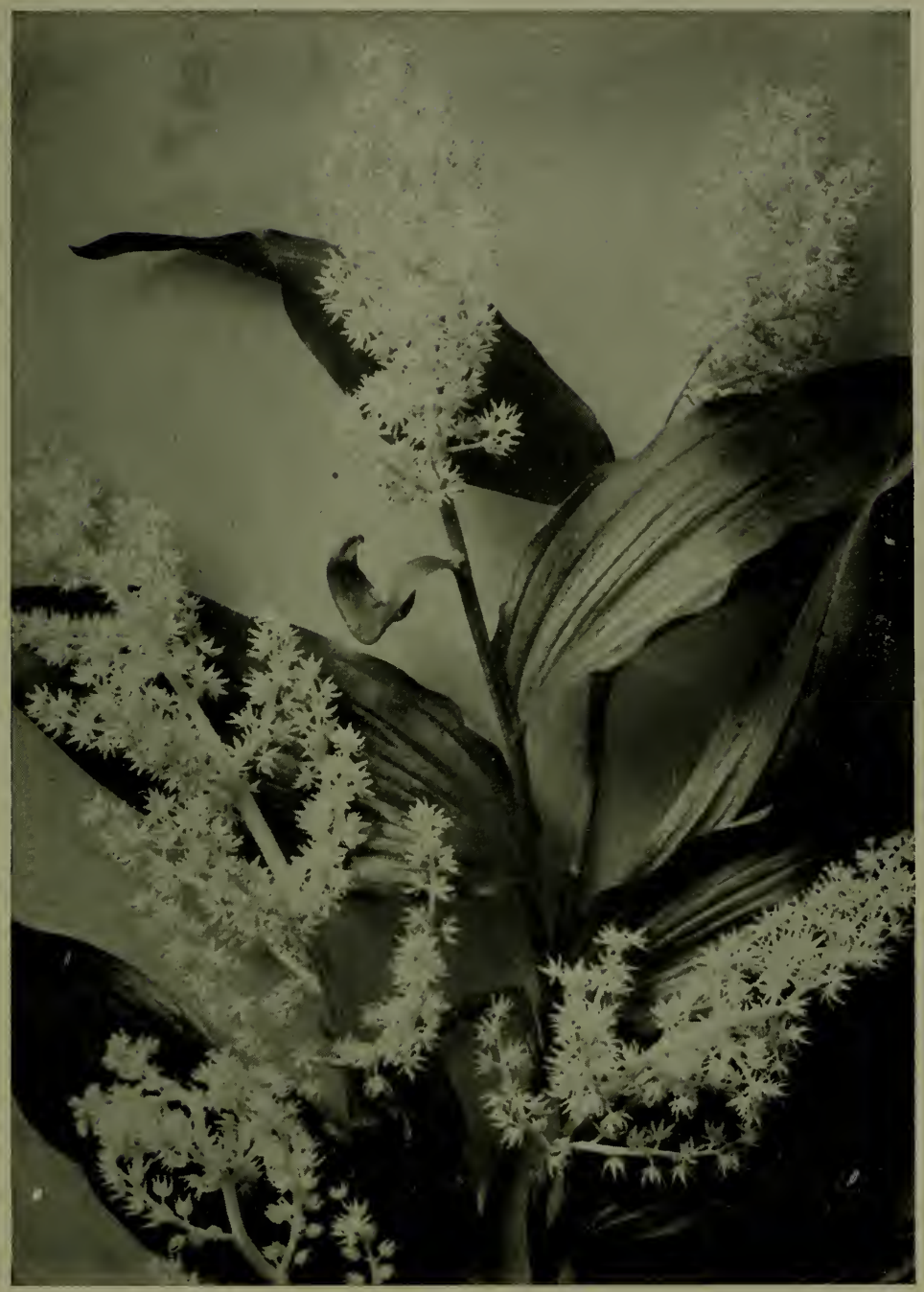

False Solomon's Seal

(Smilacina amplexicaulis) 


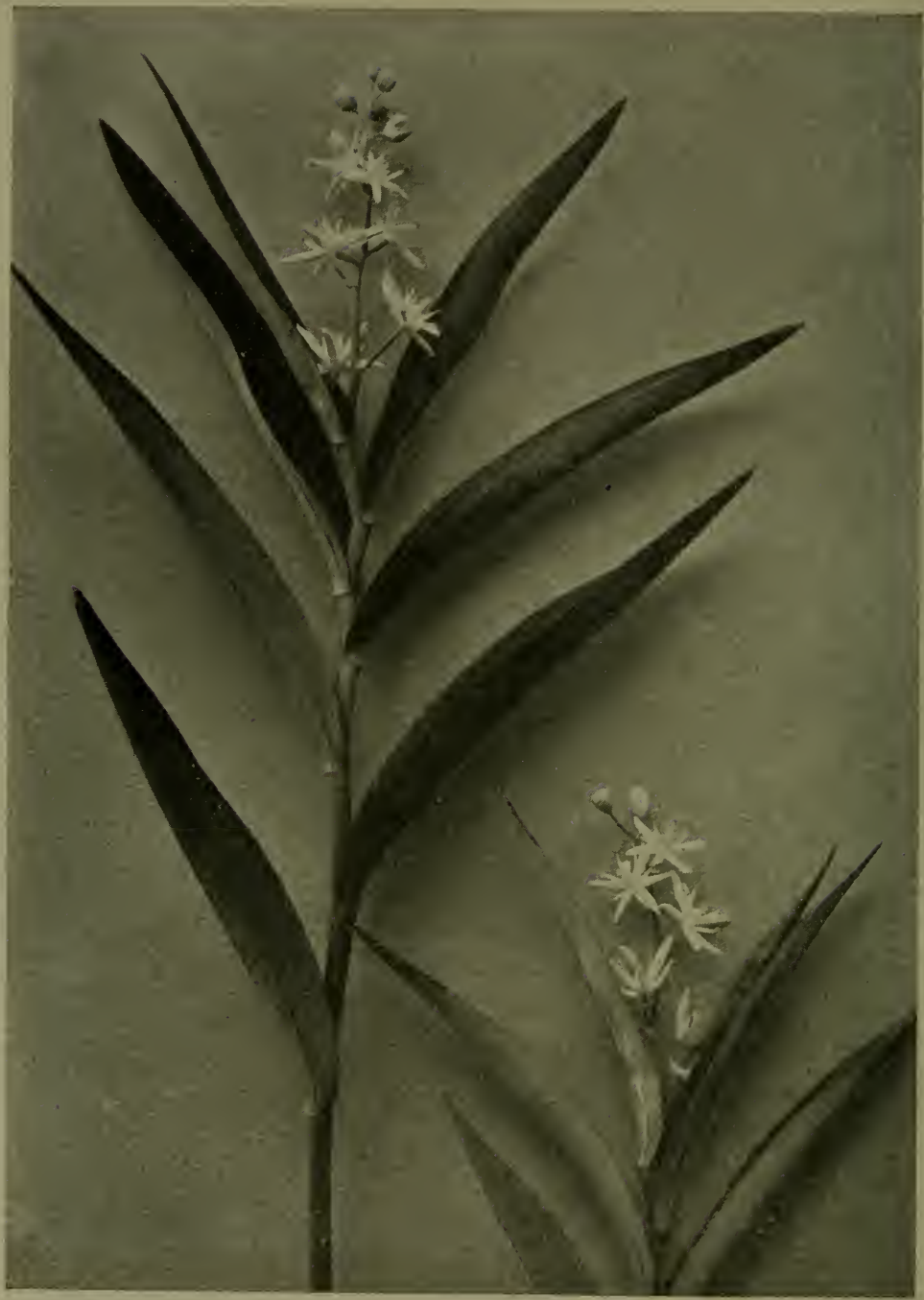

Star-Flowered Solomon's Seal

(Smilacina stellata) 
language, and it seems to me that no more fitting title could be bestowed upon the Clintonia uniflora, with its great shining leaves, amongst which are set the pure white chalices of its blossoms, than Queen-cup,- - the queen of all the snowy flower-cups of the alpine forests.

\section{FALSE SOLOMON'S SEAL}

Smilacina amplexicaulis. Lily Family

Stems: stout, ascending, leafy. Leaves: oval, clasping, acuminate, their margins minutely ciliate. Flowers: panicle densely flowered; perianth-segments oblong. Fruit: red aromatic berry, flecked with purple.

The long leafy wands of the False Solomon's Seal are exceedingly attractive, with their handsome terminal clusters of little creamy blossoms that look like feathery plumes as they wave gently to and fro in the soft summer breeze and cast their faint fragrance across the woods. Very handsome, too, are the leaves of this large plant. Why it is banned with such a base name as False Solomon's Seal I do not know. There is nothing "false" about it except its name; and while its luxuriant broad foliage resembles that of both the True Solomon's Seal and the Twisted-sta!k, still its flowers are entirely different, growing in close terminal panicles, whereas those of the other plants mentioned grow in small individual bells from the axils of the leaves. However, False Solomon's Seal is its name, and by such it is known all over the world.

Smilacina stcllata, or Star-flowered Solomon's Seal, looks to ordinary eyes very like a wild Lily-of-the-Valley, and grows near the banks of mountain streams and in the moist meadows. It is a lovely plant, stands up very stiff and 
straight out of the ground, and has stout stems which are leafy all the way from the base to the slender flower racemes. These racemes are composed of from five to fifteen little starry blossoms, each one having a white sixparted perianth. The leaves are of a whitish-green hue, and the fruit is a bright red berry clothed with purple.

\section{FAIRY BELLS}

Disporum trachycarpum. Lily Family

Leaves: alternate, ovate or oval, acute at the apex, rounded at the base, five-to-eleven nerved, sessile. Flowers: terminal, one to three on long pedicels, greenish-white or greenish-yellow ; perianth narrowly campanulate, its six segments narrowly oblong, acute, little, spreading; stamens six, hypogynous; style slender, three-lobed. Fruit: berry roughened, depressed-globose.

- The Fairy Bells have a berry with a rough coat; it is apparently leathery rather than pulpy, and contains from four to eighteen seeds. This plant is not a real shrub, but is a shrub-like herb with slender rootstocks, and branching stems that are scaly below and leafy above. It usually grows in the dense woods and attains an average height of two feet. The leaves, which somewhat resemble those of Streptopus amplexifolius, are oval and strongly nerved, very pointed at the apex and rounded at the base. The flowers usually grow in twos or threes at the ends of the slender wand-like branches, where they hang pendent on their thready stalks. They are creamy or greenish-yellow in hue, and have a floral cup that is cut into six equal narrow segments and holds six long stamens, tipped by large oblong anthers, and a three-lobed style.

Disporum oreganum, or Woolly Disporum, is diffusely branched, the stems being woolly above. The leaves are 
PLATE XIV

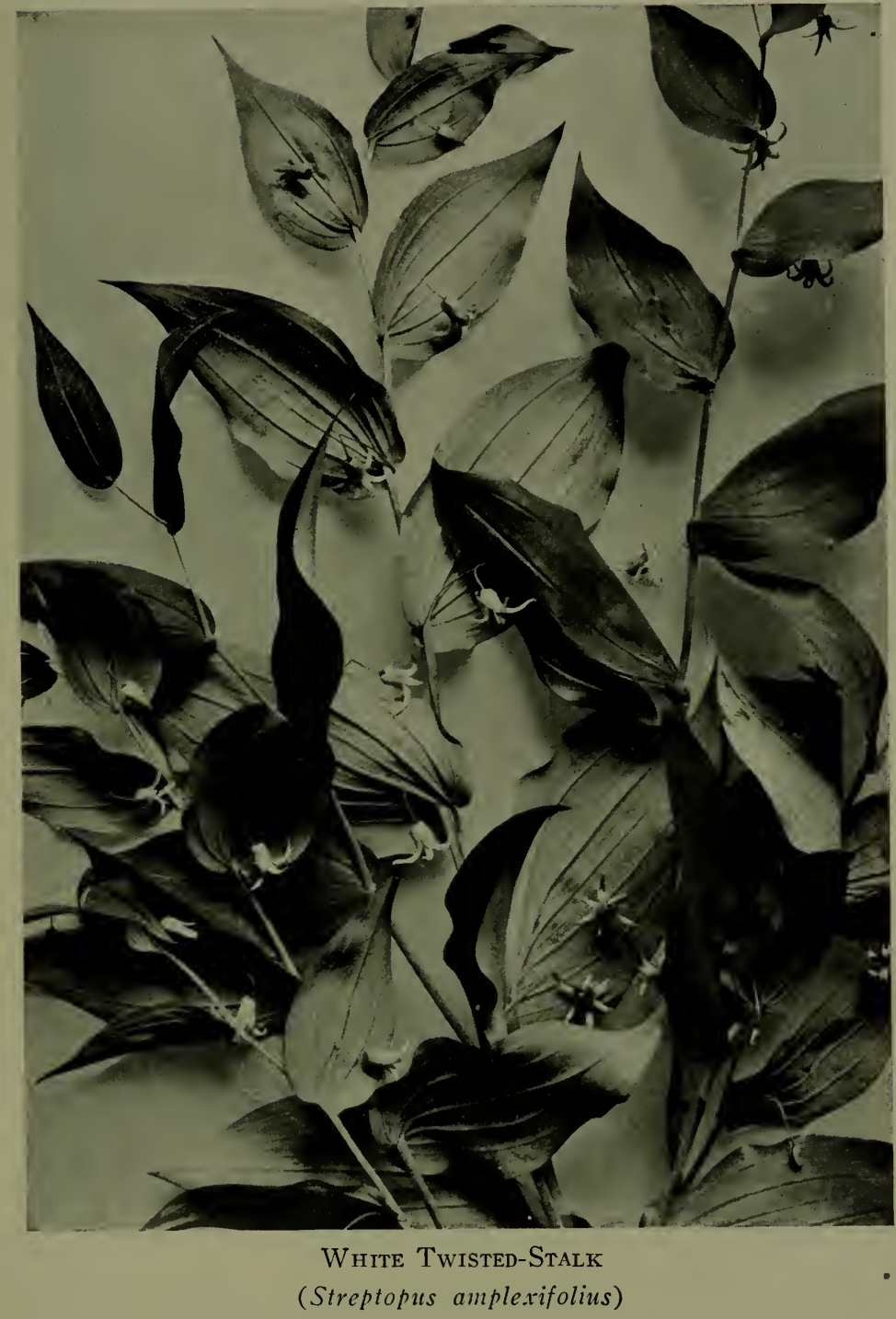




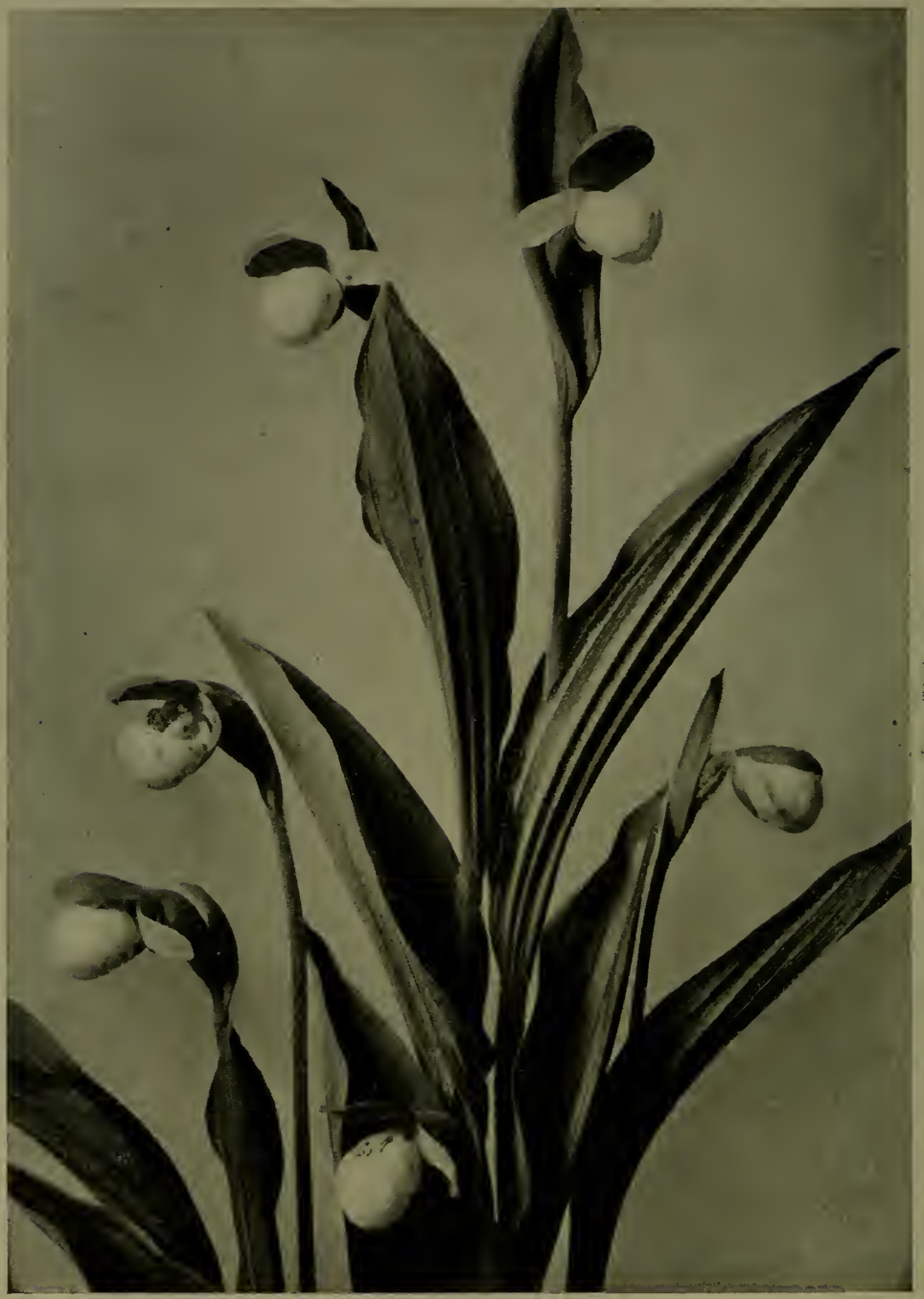

White Moccasin Flower

(Cypripedium passerinum) 
oblong pointed and heart-shaped at the base, the creamcoloured flowers are funnelform and the berries are eggshaped.

\section{WHITE TWISTED-STALK}

\section{Streptopus amplexifolius. Lily Family}

Rootstock short, stout, horizontal, covered with thick fibrous roots. Stems: glabrous, branching below the middle. Leaves: acuminate at the apex, cordate-clasping at the base, glaucous beneath. Flowers: one to two, greenish-white. Fruit: red oval berry, many-seeded.

This Twisted-stalk is a large plant with many clasping, pointed leaves growing all the way up on both sides of its long branching stems, with one solitary leaf at the apex. These leaves are handsome, green and glossy on the top, with strongly marked veins, and are covered with a whitish bloom on the underside. Looking at the plant from above it appears to bear no flowers at all, but turn over its stems and you will find beneath each leaf one or two tiny greenishwhite bells, hanging on sharply bent thread-like stalks that spring from the axils of the leaves; these flowers in time turn into bright red oval berries.

The name Twisted-stalk is derived from its abruptly bent flower stems.

\section{WHITE MOCCASIN FLOWER}

Cypripediun passcrinum. Orchid Family

Stems: stout, leafy. Leaves: ovate, acuminate. Flowers: solitary or two; petals and sepals pale green; lip dull white, veined, and with bright red spots; anther ovate-triangulate, yellow with red spots. Fruit: capsule drooping.

This is the small white Lady's Slipper, and its discovery in the mountains is of sufficiently rare occurrence to be quite an event in the history of the day to the ordinary 


\section{Io6 White to Green and Brown Flowers}

traveller. It is usually in shady places, where the soil is moist and rich, that these little velvety orchids are found. The dull white sacs, hairy inside and spotted with bright red, are quite unmistakable; the stalks are leafy and usually bear only a single terminal flower, though occasionally two shell-like blooms adorn the fat juicy stem, one at its apex and the other a couple of inches lower down.

There is a rich tropical beauty about orchids strongly suggestive of the Orient. They do not seem to be at home in the northern mountain fastnesses, but rather to belong to a world of cloudless skies and riotous foliage, where exotic flowers are set like jewels in the lavish luxuriance of the torrid zone.

\section{WHITE REIN ORCHIS}

\section{Habenaria dilatata. Orchid Family}

Stems: thick, fleshy, one to two feet high. Leaves: lanceolate, obtuse. Flowers: spike long, white, very fragrant, bracted; sepals ovate, obtuse ; lip entire, dilated; anther-sacs parallel; glands close together; stigma with a trowel-shaped beak.

To walk through the woods, deep and dark, where the trees and shrubs grow densely side by side and flowers are few and far between; and then to suddenly emerge into the open, where the sun's light is flooding across the marshlands, carpeted by myriads of tall White Rein Orchis, is a pleasure so dazzling that, once experienced, it will never be forgotten.

Fragrant as hyacinths, these exquisite snowy orchids grow to a great height in the mountain marshes, and so beautiful and wonderfully delicate are their blossoms that travellers long to transplant them to some lowland garden, in order to see their velvety spikes grow and grace civilization with a woodland loveliness. But as a rule this experi- 


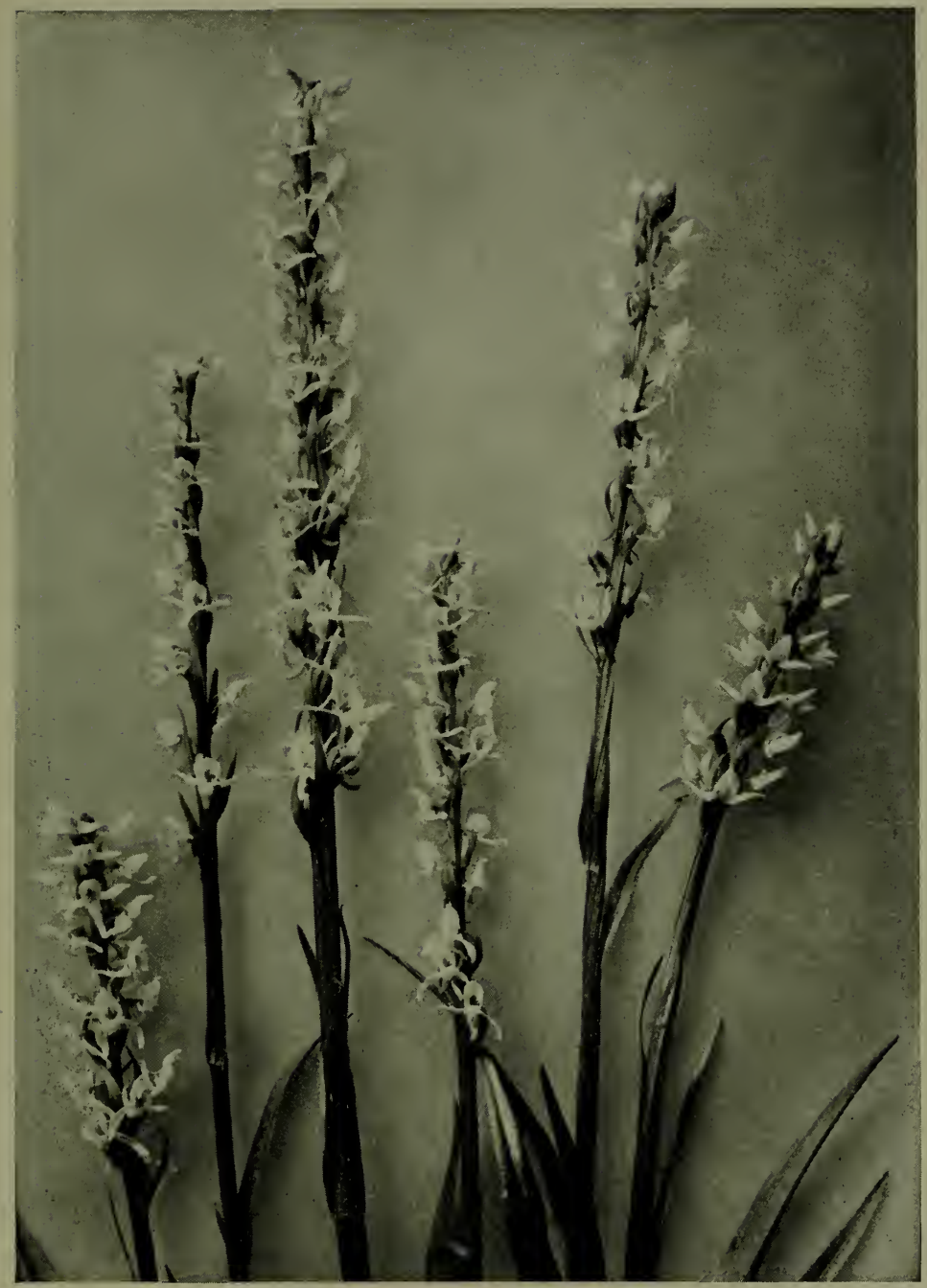

White Rein Orchis (Habenaria dilatata) 
PLATE XVII

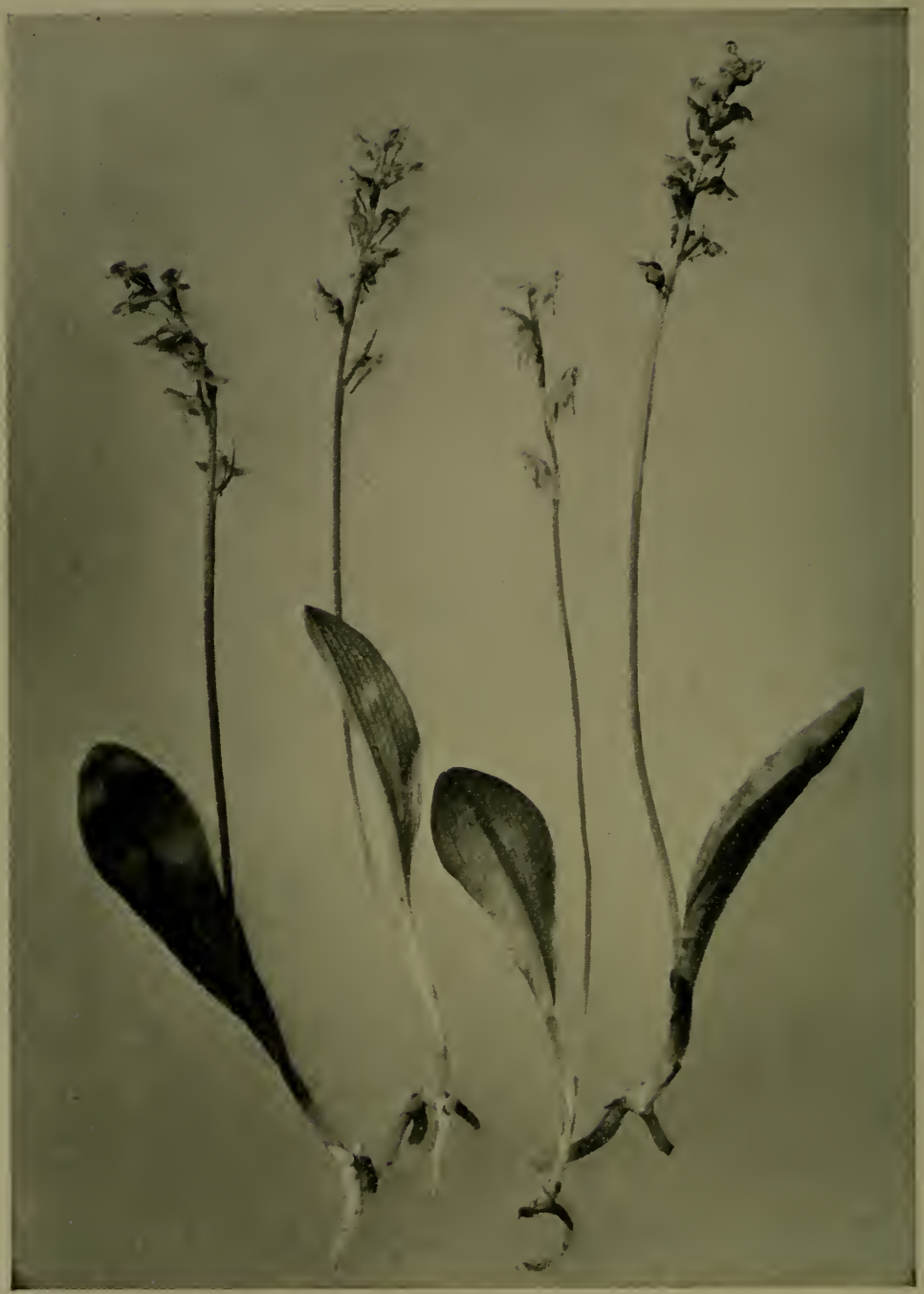

Northern Rein Orchis

(Habenaria obtusata) 
ment is tried in vain, for few of the orchids will flourish so far from their native soil.

Words fail to truly describe these plants of almost unearthly beauty. From their dainty petals

\section{"Odours ascend,}

Spreading themselves through the serener air

Where gentle breezes strive to bless,

And all God's world knows happiness."

Those who find them will always love and treasure them.

Habcnaria bractcata, or Long-bracted Rein Orchis, is one of the conspicuous green orchids which grow in great profusion in the mountain regions. It has a stout juicy stem, broad leaves, and many long pointed bracts on its flowerspike. Usually found in wet places, this Orchis may always be distinguished by the long bracts, from which it derives its name.

Habenaria obtusata, or Northern Rein Orchis, is a delicate green and white Orchis that may always be known by its single basal leaf. It is very like a white and green Lilyof-the-Valley, and its flowers grow widely separated on the slender stalks.

Habcnaria hyperborea, or Leafy Rein Orchis, somewhat resembles $H$. obtusata, but may easily be distinguished by the fact that it has several leaves growing up on and clasping its stem, which is also decidedly stouter than the stem of the preceding species. The Leafy Rein Orchis grows in the open woods, preferring a moist spot. It has many flowers on each stalk, and they grow closely set together.

Habenaria gracilis, or Graceful Rein Orchis, has a tall slender stem and long narrow leaves which are gradually reduced as they grow upwards and eventually pass into the 
bracts of the narrow sparsely-flowered spike. The flowers are small, greenish-yellow, and have a short spur.

Habenaria orbiculata, or Round-leaved Rein Orchis, may readily be recognized by its two very large glistening orbicular leaves that spread out flat upon the ground, and which are green and shining above and quite silvery beneath. The large greenish-white flowers of this handsome plant grow in a loose raceme on the slender scape-like stems, and have a short rounded upper sepal and spreading lateral ones, the entire obtuse white lip being longer than the petals.

\section{HOODED LADIES' TRESSES}

\section{Spiranthes Romanzoffiana. Orchid Family}

Root tuberous. Stems: glabrous, leafy below, bracted above. Leaves: oblong-lanceolate. Flowers: spike dense, in three rows, conspicuously bracted; perianth white, the petals and sepals all connivant, lip recurved, ovate-oblong, contracted below the narrower wavy-crenulate summit.

This is the last orchid of the season, found chiefly in wet marshy places, just when the power of the summer sun begins to wane. It is a beautiful fragrant flower, growing in dense snowy spikes, and has long narrow leaves. Considering that orchids are reckoned as amongst the rarest and richest treasures of Nature, it is strange how many species of them grow wild in the mountains. Of course they are all terrestrial ones; we have none of the kinds which grow on trees and develop false bulbs.

\section{STOUT RATTLESNAKE PLANTAIN}

Epipactis decipiens. Orchid Family

Stems: scape glandular pubescent. Leaves: blotched with white, ovate. Flowers: galea concave, ovate, with a short, spreading, recurved tip; anther ovate, pointed on the base of the stigma into a gland-bearing awl-shaped beak. 
PLATE XVIII

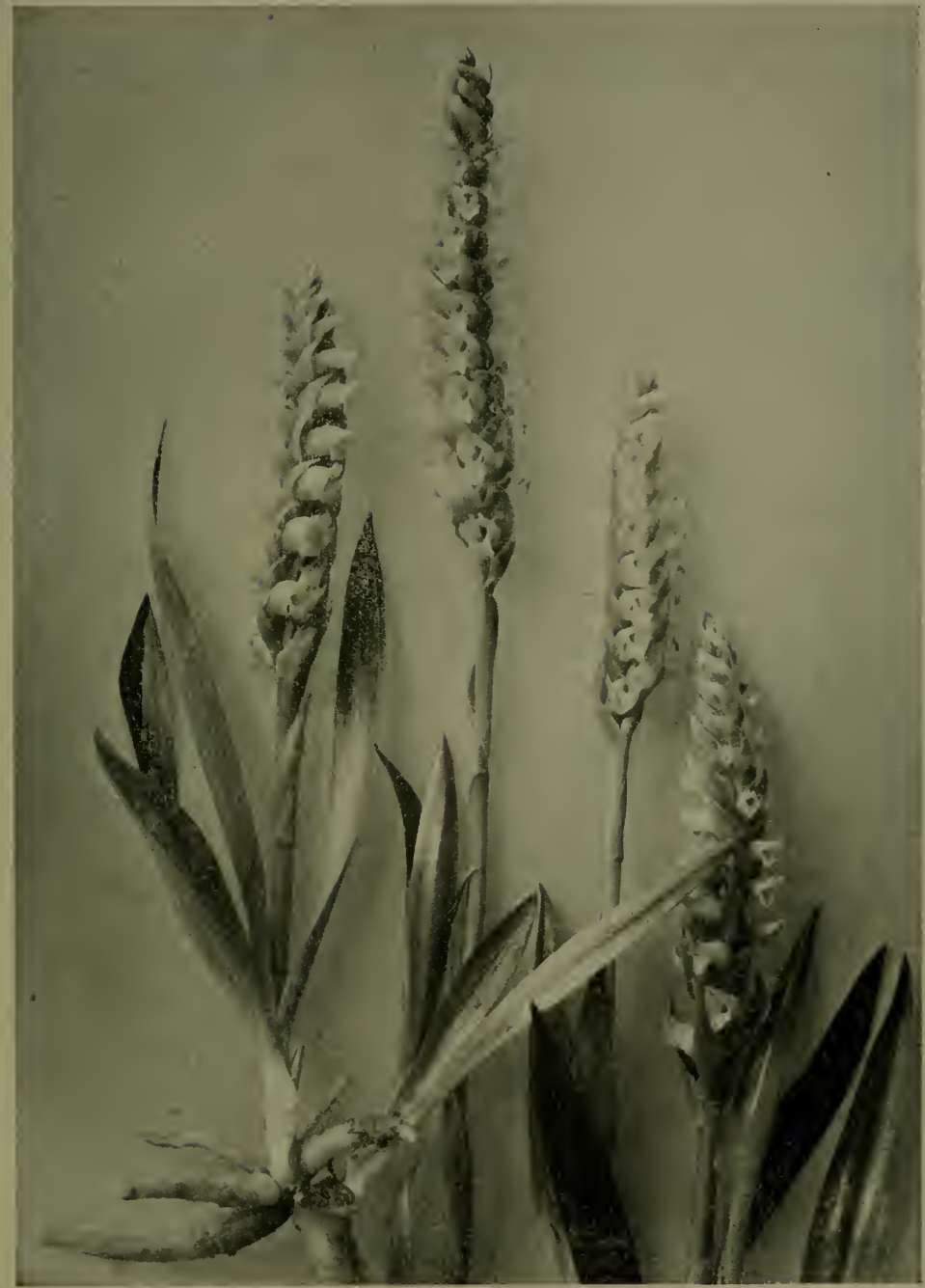

Hooded Ladies' Tresses

(Spiranthes Romanzoffiana) 
This plant has a cluster of leaves at the base only; these are covered with a network of white veins and frequently also have white blotches on them. The flowers grow in a bracted spike, are greenish-white, and have a very hairy stalk.

Epipactis repens, or Small Rattlesnake Plantain, has also peculiar white-veined leaves, but in this species they grow up the stalk as well as at its base. The whole plant is smaller than E. dccipicns, and its insignificant flowers grow only on one side of the stem, which is much bracted and hairy. The name "Rattlesnake" applies to the resemblance between the curiously veined leaves and the body of a snake. This plant frequently grows in decaying wood.

\section{HEART-LEAVED TWAYBLADE}

\section{Listera cordata. Orchid Family}

Root: fleshy-fibrous. Stems: very slender. Leaves: sessile, cordate, ovate, mucronate. Flowers: in racemes, minute pedicels bracted; sepals and petals oblong-linear, lip narrow, the segments setaceous and ciliolate.

A small orchid with two large leaves growing midway up its slender stem, by which it may always be readily recognized. The flowers are purplish-green, very tiny, and are set in a small raceme at the top of the stalk. It grows in the cool woods.

Listera coni'allarioides, or Broad-lipped Twayblade, also has the same two distinguishing stem-leaves, which, however, are rounder than in the foregoing species, while its flowers are yellowish-green, fairly large, and possess a broad lip with two lobes at the delicate apex.

The Twayblades present a strong contrast to the Coral Roots, They are conspicuously green and healthy of leaf. 


\section{EARLY CORAL ROOT}

\section{Corallorhiza trifida. Orchid Family}

Root: coralloid, branching. Stems: glabrous, clothed with closely sheathing scales. Flowers: in long racemes on short minutely bracted pedicels; sepals and petals narrow, lip short; spur a sac adnate to the summit of the ovary. Fruit: capsule oblong.

A plant impossible to mistake, for its roots are exactly like branches of coral, composed of thick, white, blunt fibres, and may be found in moist shady places. The flowers grow in a raceme on single, thick, fleshy stems, that are clothed with closely sheathed bracts and are of a queer purplishgreen colour, frequently marked with white. It has no leaves.

The Coral Root is a saproplyyte; that is to say, it lives upon the dead and decomposing forms of other plants, and this explains why it is such a vegetable degenerate of the beautiful family of orchids. It has lost its leaves, also its chlorophyll, or honest green colouring matter, through its bad habits, and to-day belongs to that pirate tribe which feeds upon food already assimilated by another, and thereby incurs the displeasure of Nature, whose laws demand honest conduct in her kingdom as sternly as do those of man; and so, when the Coral Root refused to manufacture its own upbuilding materials out of the carbon dioxide of the atmosphere, and proceeded to prey upon decaying matter, Nature took away its leaves and chlorophyll and only left it sufficient branching extensions at the base to secure it in the soil.

Corallorhisa maculata, or Large Coral Root, grows as high as twenty inches and has purplish-green flower-stalks clothed with scales. The numerous flowers are purplishbrown, and the lip white-spotted and lined with purple, the 
middle lobe being broader than the lateral ones and the apex curved. The spur is yellowish.

Corallorhi a striata, or Striped Coral Root, has dark purplish-brown flowers with elliptic petals, an oval lip, and no spur.

Corallorhiza Mertensiana, or Spurred Coral Root, has numerous reddish-green flowers, usually a toothed lip narrowed to a claw and a very marked spur.

\section{COMMON NETTLE}

Urtica Lyallii. Nettle Family

A herb with stinging hairs. Leaves: ovate, acute, coarsely serrate. Flowers: in loose, spreading, slender panicles. Fruit: an achene.

The Common Nettle is too well known to require any description with its panicles of small greenish flowers, coarsely toothed leaves and quantities of stinging hairs.

\section{WHITE COMANDRA}

Comandra pallida. Sandalwood Family

Stems: glaucous, slender, simple, very leafy. Leaves: linear, acute, sessile. Flowers: cymes several-flowered, corymbose, clustered at the summit, peduncles short.

The Comandra is parasitic on the roots of other plants. It has pretty little whitish-green flowers, which grow in clusters and are bulb-shaped at the base, spreading out into five lobes at the top. The leaves are very narrow and grow close to and all the way up the stalk, and the fruit is a nutlike berry, which retains at its tip the upper short part of the calyx.

Comandra livida, or Swamp Comandra, differs from the foregoing species in that it has wider leaves, each one growing on its own tiny stalk attached to the main stem; and 


\section{PLATE XIX}

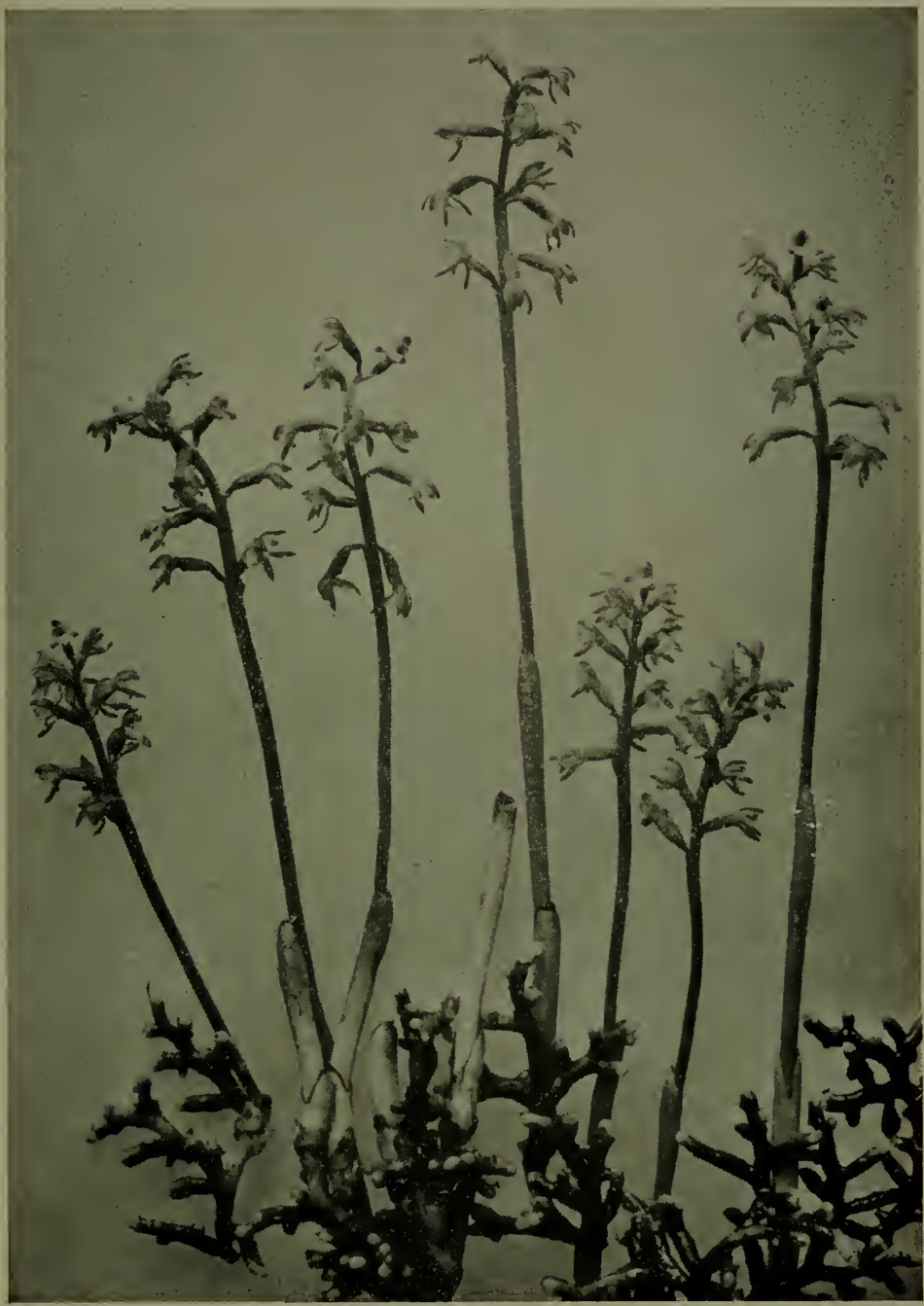

Early Coral Root

(Corallorhiza trifida) 
whereas the flowers of the White Comandra grow in clusters at the top of the stems, those of the Swamp Comandra grow in the axils of the leaves lower down on the stems, and its fruit is a roundish red and edible berry. It is a parasite on the roots of Cormus canadensis.

Comandra Richardsiana, or Green Comandra, has very leafy branched stems, oblong pointed leaves and greenishwhite or purplish flowers growing in flat-topped clustered heads and also in the axils of the leaves. The fruit is a round berry containing a stone. This plant is usually found in dry open places.

\section{WITCH'S BROOM}

Arceuthobium americanum. Mistletoe Family

Stems: slender, much branched. Flowers: the staminate and pistillate on separate plants, borne on terminal peduncle-like joints. Fruit: a fleshy, flattened berry borne on a short recurved peduncle.

This fleshy plant is parasitic on Pinus contorta var. Murrayana. It has four-angled much-jointed branches, and small scales in the place of leaves. The tiny flowers are yellowish-green and the fruit is a purplish-brown berry.

\section{TALL ERIOGONUM}

Eriogonum umbcllatum var. majus. Buckwheat Family

Stems: depressed and shrubby below, much branched. Leaves: oblong, white tomentose below, green and glabrous above; peduncles six to fifteen inches high, naked, bearing a simple umbel of three to ten rays, subtended by a whorl of leaves.

A somewhat rare and most curious plant. In dry stony places and on rocky slopes you will find the long-stalked blossoms of the Tall Eriogonum, with its handsome flattopped clusters of cream-coloured flowers, tipped and tinged 


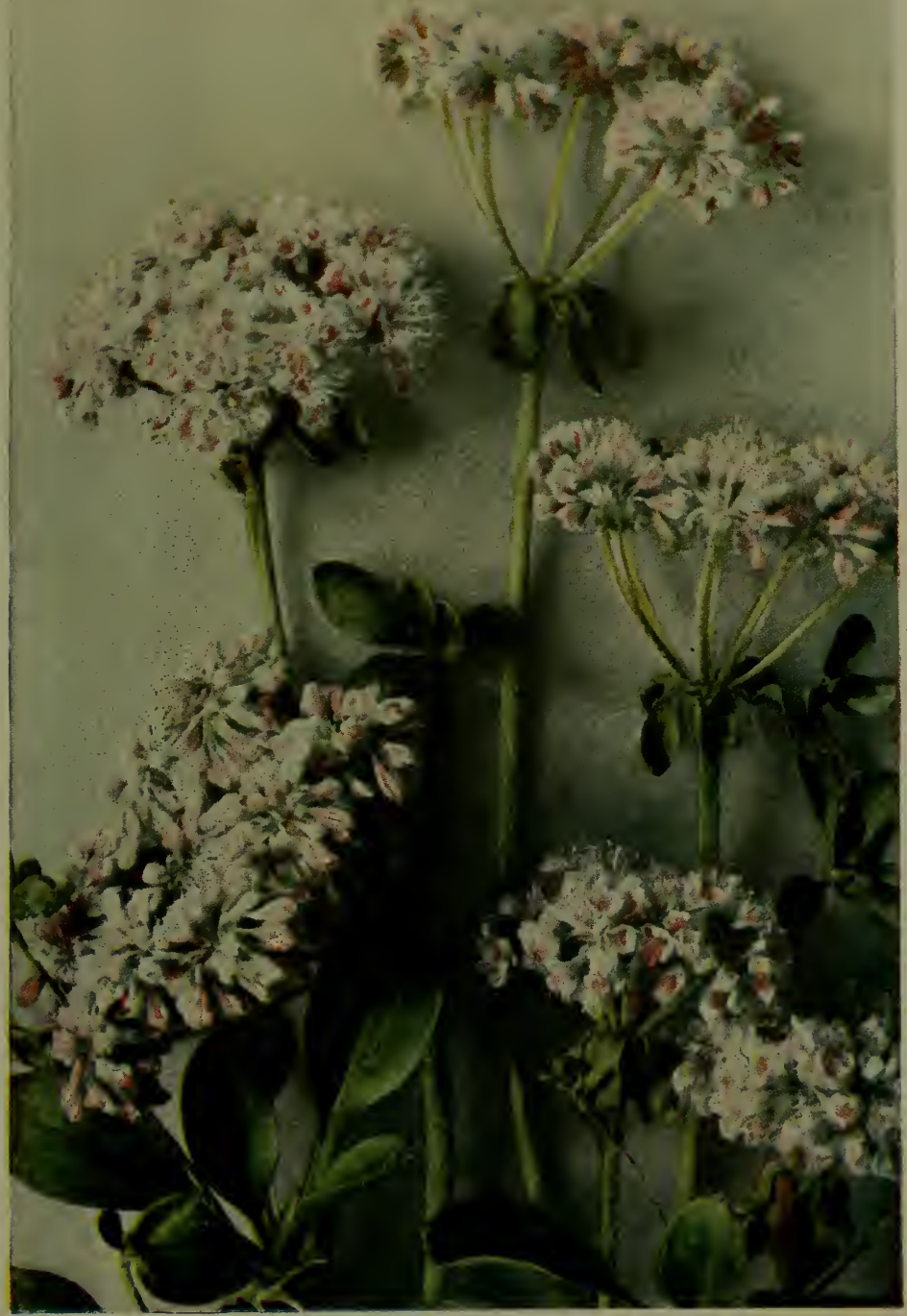

Tall Eriogonum

(Eriogonum umbellatum zar. maius) 

with vivid rose pink, that have a peculiar bunch of tiny narrow leaves set just where the little stems of the individual flower-umbels spring from the top of the main stalk.

It is also a most fascinating plant, both by reason of the fact that its fine cream and rose blossoms grow in barren localities, and also because its leaves (which are green above and silvery beneath) grow near to the ground, on slender, branching, woody stems, while the flower-stalks are extremely long, often reaching a height of over twelve inches.

Eriogonum ovalifolium, or Silvery Eriogonum, is a densely woolly and silvery plant with very short stems and oval leaves crowded on the numerous branches. The flowers are yellowish-white, tinged with rose-colour, and grow in a single head on each stalk.

Eriogonum androsaceum, or Dwarf Eriogonum, is the alpine species, and almost an exact reproduction in miniature of its "Tall" relation. The chief difference between the two plants is that the Dwarf Eriogonum is more hairy and woolly, and generally has cream-coloured flowers without any tingeing of pink. It only grows about three inches high, and is found at 7,500 feet.

\section{MOUNTAIN SORREL}

\section{Oxyria digyna. Buckwheat Family}

A low fleshy herb. Stems: slender, erect, simple. Leaves: reniform, undulate, the basal long-petioled. Flowers: in terminal panicled racemies. Fruit: an achene, pointed, smooth, surrounded by a broad membranous wing.

A perennial herb with mostly basal kidney-shaped leaves on long stalks and clusters of small green flowers. The leaves are acid. 


\section{WILLOW-LEAVED DOCK}

Rumex salicifolius. Buckwheat Family

Stems: erect, ascending or spreading, simple or branched, grooved. Leaves: lanceolate, acute at both ends. Flowers: in dense clusters. Fruit: the faces of the achenes concave, smooth, shining, winged.

A large coarse plant growing several feet high, with a strongly grooved stem, huge long-shaped bluish-green leaves that are pointed at both ends, and panicles of green flowers set in loose whorls near the apex of the stalks. These flowers have no petals, but only a green six-parted calyx, the three outer divisions of which remain unchanged in fruit, while the three inner sepals develop into wings. The fruit is dark red.

Rumex Acetosa, or Common Sorrel, is a much smaller plant, and has arrow-shaped leaves, and green flowers tinged with red, which deepen in colour to a purple-red as the season advances. The leaves and juicy stems are slightly acid, and the root is very astringent, yielding an excellent red dye. This is an introduced plant.

Rumex Acetosella, or Field Sorrel, has a creeping rootstock, and halberd-shaped leaves which are pointed at the apex. The green flowers are tiny and grow in a loose raceme. This plant flourishes in the poorest soil, and towards the end of the summer turns a rich red colour. This is an introduced plant.

\section{ALPINE BISTORT}

Polygonum viziparum. Buckwheat Family

Stems: slender, simple. Leaves: ovate, subcordate, attenuate at base; cauline leaves lanceolate. Flowers: raceme narrowly cylindric, densely flowered, bearing a number of ovoid-conic bulblets at base. 


\section{PLATE XX}

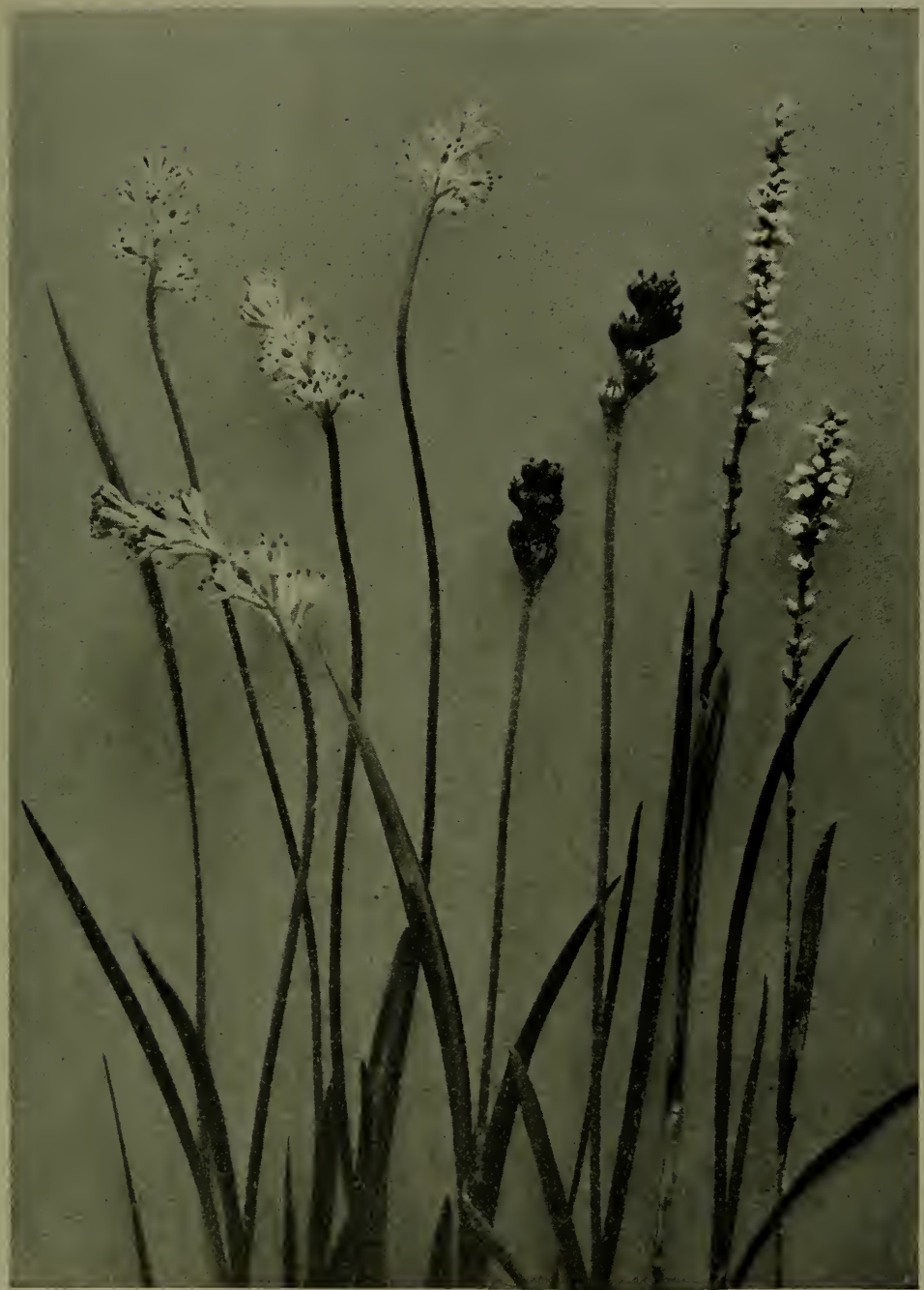

Alpine Bistort (Polygonum viviparum)

Glutinous Asphodel (Tofieldia glutinosa) 
The name Poly'gonum comes from the Greek, its meaning being " many-kneed," and refers to the enlarged joints of the stems, which are sheathed by the stalks of the longshaped leaves. The flowers are very numerous in the mountains, are white to rose colour, and grow in dense narrow spikes, which have several little bulbs below the fullblown blossoms. The seeds are red.

Polygonum bistortoides, or Heart-leaved Bistort, is covered with a white bloom throughout. The root leaves are oblong, and the stem ones narrow and somewhat heartshaped, all with rolled-back margins and conspicuously nerved. The elongated flower-clusters are usually white, rarely pink; they are very dense and are not bulblet-bearing below.

\section{LAMB'S QUARTERS}

\section{Chenopodium album. Goosefoot Family}

Stems: slender, erect, commonly much branched. Leaves: rhombicovate, the upper ones lanceolate, obtuse or acute. Flowers: bractless, densely clustered in a compound panicled spike; calyx segments strongly keeled. Fruit: seed firmly attached to the pericarp.

A weed that abounds near habitation, even in the mountain regions. A commonplace plant, and yet one that is not altogether without beauty, since its foliage is of an unusually delicate tender green. The white flowers, which grow in dense spikes, are inconspicuous. This is an introduced plant.

Chenopodium capitatum, or Strawberry Blite, is a very appropriate name for this plant, which flourishes best in newly up-turned or half-cultivated soil, where its pale green foliage and bright red fruit render it conspicuous. The leaves are halbert-shaped, thin, and pointed both at the apex and at the ends of the basal lobes, the margins being more 
or less indented. The flowers are small and greenish, but the developed fruit is extremely attractive in appearance, resembling a strawberry and consisting of a brilliant red pulpy berry, which has numerous seeds embedded in its wrinkled surface, similar to those which cover the exterior of the Garden Strawberry.

\section{BLUNT-LEAVED SANDWORT}

Arenaria lateriflora. Pink Family

Stems: erect, slender, simple or branched. Leaves: thin, oblong, obtuse, punctate, hairy on the margin and midrib. Flowers: petals oblong, obtuse, twice longer than the sepals. Fruit: a capsule.

The Sandworts are rather insignificant plants with more or less rigid leaves and small white flowers growing in compound clusters or flat heads. The Blunt-leaved Sandwort is rather hairy and has oblong dotted leaves which terminate in a rounded apex, and a spherical capsule containing large smooth seeds.

Arenaria capillaris var. nardifolia, or Narrow-leaved Sandwort, has sharp-pointed leaves grouped in dense clusters at the base of the plant, the few stem leaves being much reduced.

Arenaria z'erna var. propinqua, or Vernal Sandwort, has densely-tufted flowering stems bearing pairs of tiny leaves all the way up them.

Arenaria sajanensis, or One-flowered Sandwort, has slender one-flowered stems and narrow leaves.

\section{LONG-STALKED STITCHWORT}

Stellaria longipes. Pink Family

Stems: smooth. Leaves: ascending, linear-lanceolate. Flowers: few, on long slender pedicels; petals two-cleft; sepals ovate, Fruit: capsule ovoid, Seeds smooth. 


\section{I22 White to Green and Brown Flowers}

A pretty little plant, with whitish-green leaves, very pointed at the ends, and tiny white flowers growing at the apex of the long slender stalks.

Stellaria borealis, or Northern Stitchwort, has weak much-branched stems and a terminal leafy flower-head.

\section{FIELD MOUSE-EAR CHICKWEED}

Cerastium arvense. Pink Family

Stems: erect, pubescent with reflexed hairs, cespitose, four to eight inches high. Leaves: linear-oblong, acute, clasping; bracts small. Flowers: cymose, few-flowered; petals five, obcordate.

This is quite the prettiest and most attractive of all the Chickweeds, and will be found growing in profusion on many a sunny bank and dry meadow during the months of June and July. It is frequently called "Star of Bethlehem," and has five snow-white petals, each of which is divided at the edge. All the Chickweeds are white. Like the meek they certainly inherit the earth. In almost every part of the world their varying methods of cross and selffertilisation have resulted in these little plants following closely in the footsteps of man's civilization. The following story is told by Sir Joseph Hooker; he says: "Upon one occasion landing on a small uninhabited island nearly at the Antipodes, the first evidence I met with of its having been previously visited by man was the English Chickweed; and this I traced to a mound that marked the grave of a British sailor, and that was covered with the plant, doubtless the offspring of seed that had adhered to the spade or mattock with which the grave had been dug."

Cerastium alpinum, or Alpine Mouse-ear Chickweed, is a silky-haired species, with whitish leaves, and large white flowers. When Dr. Sutherland went to Baffin's Bay in 
I 85 I to search for Sir John Franklin, he found this tiny plant growing close to the icebergs. He says in his Journal: "Button Point looked as green as any English meadow, and the grass upon it was not one whit less luxuriant. The Foxtail Grass and the Chickweed (Cerastium alpinum), and hosts of other grasses and herbaceous plants, grow among the bones of animals, and are stimulated by the oil and animal matter which they contain, and by the filth which is inseparable from Esquimaux habitations, to a degree of luxuriance which no one would be willing to assign to the 73 rd degree of north latitude." The scientific name is derived from Ceras, a horn, in reference to the shape of the seed-pods of some of the species.

\section{NODDING PINK}

Lychnis apetala. Pink Family

Stems: one-flowered. Leaves: linear, sessile. Flowers: nodding, petals narrow, two-cleft, included in the calyx, calyx inflated, its teeth triangular-ovate, acute. Fruit: a capsule.

This Pink is an arctic-alpine plant with very narrow leaves growing in pairs up the stem, and nodding white flowers which become erect in fruit. The five petals are enclosed and almost hidden within the green inflated calyx which is strongly purple-veined, tubular, and sharply toothed.

Ly'chnis Drummondii, or Drummond's Pink, is a hairy, sticky, tall plant with numerous erect white, or rarely purplish flowers.

\section{WHITE CAMPION}

Silene Macounii. Pink Family

Stems: slender, from a branching rootstock, minutely pubescent. Leaves: linear-oblanceolate. Flowers: few, on pedicels ; calyx inflated, 


\section{I24 White to Green and Brown Flowers}

with short obtuse teeth; petals little exserted, with a broadly-auricled claw, and large, thin quadrate appendages, the flabellate bifid blade with a linear tooth on each side.

Like many of the Campions, this one is very sticky, and is characterized, in common with other members of the Pink Family, by its slender stems being jointed and the leaves set in pairs at the joints. It gives out a faint sweet odour, and is usually found growing among the stones on steep hillsides.

Silcne Lyallii, or Lyall's Catchfly, has spoon-shaped basal leaves and long narrow stem leaves. The white flowers grow on short stalks in loose terminal heads; the inflated calyx has purple-tipped teeth and the petals are spreading and two-lobed. The flowers are sometimes purplish.

\section{LANCE-LEAVED SPRING BEAUTY}

\section{Claytonia lanccolata. Purslane Family}

Stems: weak, from a tuber. Leaves: few, opposite, oblong. Flowers: in a loose raceme on slender pedicels, nodding, white or pale pink; veins rose; calyx of two ovate sepals; petals five; style threecleft at apex.

Close to the snow, in warm wet valleys, when the June sunshine has awakened the alpine world from its winter sleep, you will find the Spring Beauty, and as you stoop to gather it the whole plant (consisting of a tuberous root and one stalk with two leaves upon it and a cluster of blossoms at the top) will inevitably come up in your hand, so easily does it leave the ground. No sooner does this happen than the petals begin to close, the leaves to droop, and the stem to grow limp. Ten minutes afterwards the flower is hopelessly wilted. Whether white or delicate pink, the Spring Beauty is always veined with bright rose colour. There are few more exquisite wild blossoms on this continent than 
"These little dream-flowers found in Spring,"

of which Longfellow wrote in "Hiawatha" :

"Where the fire had smoked and smouldered, Saw the earliest flower of Spring-time, Saw the Beauty of the Spring-time, Saw the Miskodeed in blossom."

Miskodecd is the Indian name for the Spring Beauty.

Claytonia megarrhiza, or Alpine Spring Beauty, has numerous wedge-shaped basal leaves rounded at the apex and with a dilated base; the stems not exceeding these leaves in length. The stem leaves are narrow and the white to pinkish and yellowish flowers grow in a one-sided cluster, and have conspicuous bracts. This plant has a very large tap-root which penetrates to a great depth in the crevices among the rocks at high altitudes.

Claytonia pariifolia, or Small-leaved Spring Beauty, has tiny fleshy oval leaves, and white to pinkish loosely-flowered clusters of blossoms at the ends of the numerous stems. It propagates freely by bulblets in the axils of the stem leaves, as well as by seed.

\section{WESTERN MEADOW RUE}

\section{Thalictrum occidentale. Crowfoot Family}

Stems: slender, one to three feet high. Leaves: ternate, the lower ones petioled. Flowers: nodding on very slender pedicels in an ample open panicle; filaments purplish-green; anther linear, cuspidate; calyx of four to eight sepals that fall early. Fruit: achenes one to ten in each head, ribbed, lanceolate.

A dainty plant, with delicate foliage closely resembling robust Maidenhair Fern. The eye of the traveller is at once caught by its pretty tassels, which hang in clusters and are of a pale green colour, tipped with reddish-purple. It is 
frequently found along the margins of alpine streams, being much admired in fruit, when it shows numerous seed-bcaring stars, tipped with thread-like points.

Thalictrum megacarpum, or Veiny Meadow Rue, has purplish stems, ternate leaves, purplish-green flowers and wedge-shaped achenes tapering into a short beak. The filaments are not so long as in the preceding species.

\section{CHALICE CUP}

Anemone occidentalis. Crowfoot Family

Stems: erect, six to eighteen inches high. Leaves: large, longpetioled, biternate and pinnate. Flowers: large, solitary; petals none; sepals five to seven. Fruit: carpels with long filiform styles that become plumose tails to the achenes.

The Chalice Cup is one of the most beautiful of the early spring mountain flowers. Its handsome white blossoms, purple-shaded on the outside, may be found growing close to the retreating line of snow during the months of May and June, and later on in the season its big fluffy seed-heads are eagerly gathered by those who delight in artistic things. This plant, like many others of the Crowfoot Family, has no petals, only a lovely calyx fashioned into about six sepals, which do duty instead.

Anemone multifida, or Wind Flower. as this delicate little Anemone is called, appears on the dry meadows in the springtime in a vast variety of hues, with many blossoms and much fruit. Its colours range from white to red, with many intermediate shades of yellow, pink, and purple-blue. It is to Pliny, the famous ancient philosopher, that it owes its name, for he declared that only the wind would cause Anemones to open; while a later poet has sung how Venus in her grief over the death of Adonis "poured out tears 
PLATE XXI

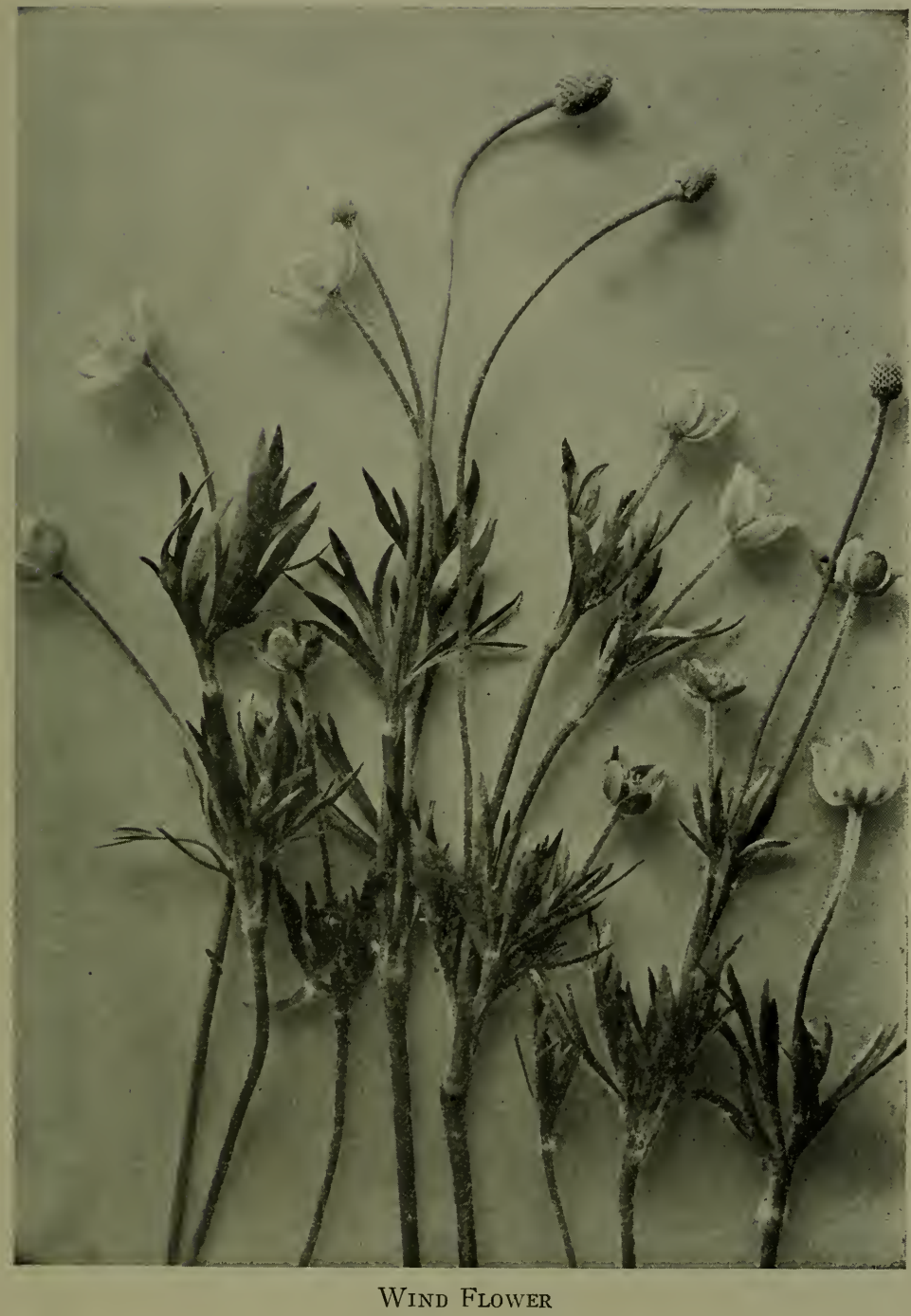

(Ancmone multifida) 


\section{28 White to Green and Brown Flowers}

amain," and how "gentle flowers" were born to bloom at every drop that fell from her lovely eyes:

"Where streams his blood, there blushing springs the rose, And where a tear has dropped, a Wind Flower blows."

They are short-lived flowers; the wind blows them open and wafts them away. Rapidly the fruit is formed in a thimble-like head, which presently bursts and is seen to contain many white woolly seeds. The leaves are very deeply cleft.

Anemone Drummondii, or Alpine Anemone, has a larger flower and thicker stalks than $A$. multifida; it also grows higher up on the mountains, and may be found close to perpetual snow. The leaves are set in a circle round the stalk, about two inches below the blossom, and also grow up from the base of the plant. They are not so delicate or deeply cut as those of $A$. multifida. The flower is rather like a white buttercup, and is usually shaded with pale blue on the outside. The centre is yellow and green.

Anemone pariflora, or Few-flowered Anemone, the smallest and most delicate of all the mountain Anemones, is usually found growing in the thick forests, single and solitary. The flowers are white, veined and shaded with blue at the base of the sepals.

\section{WHITE CLEMATIS}

Clcmatis ligusticifolia. Crowfoot Family

Stems: somewhat pubescent. Leaves: quinate to quinate-ternate, leaflets oblong, acute, incisely lobed and trifid. Flowers: in paniculate corymbs. Fruit: achenes pubescent.

The White Clematis has open clusters of rather small flowers composed of five thin silky petaloid sepals, oblong lobed leaves, and handsome plumose seed-heads. This 


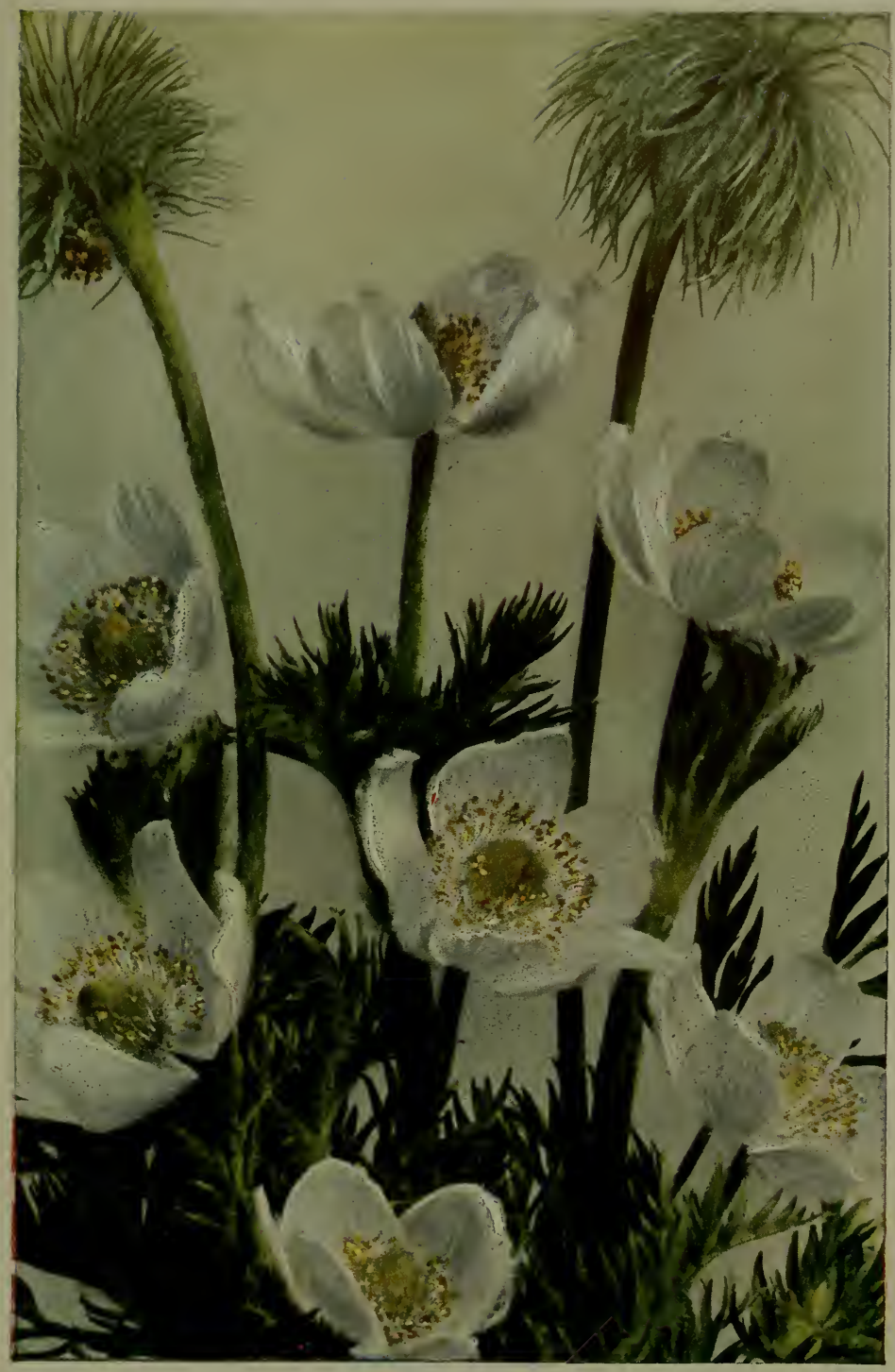

Chalice Cup

(.tnemone occidentalis) 

climbing plant is usually found along the banks of the alpine streams.

\section{ALPINE MARSH-MARIGOLD}

Caltha leptosepala. Crowfoot Family

Stems: erect. Leaves: oblong-cordate, irregularly crenate-toothed. Flowers: sepals petaloid, lanceolate, acute.

This plant is found chiefly in moist localities, and often grows abundantly in the wet alpine meadows at high elevations, where its white flowers, whose petaloid sepals are deeply tinged with purple-blue on the outside, are extremely beautiful set among their rich large-leaved foliage. The stems bear one or two flowers, the lower of which is subtended by a noticeable leaf-like bract.

\section{WHITE GLOBE FLOWER}

Trollius laxus var. albiflorus. Crowfoot Family

Stems: weak, ascending. Leaves: palmately divided, the segments many-cleft. Flowers: solitary; sepals five to six, white, with a greenish tinge outside; petals fifteen to twenty-five, bright yellow, minute, much shorter than the numerous stamens.

The White Globe Flower is one of the most conspicuous of all the early spring mountain plants that grow at very high altitudes. Close to the borders of alpine lakes and streams, and in marshy places where the snow has recently melted, beds of this beautiful large white flower may be found, its brilliant golden centre gleaming in the sunshine, and its rich, glossy foliage forming a superb setting for its perfect purity.

Do not confuse it with one of the Anemones. Note that its centre is far larger and more golden in hue; also that the foliage is coarser and thicker. There is a bushy circle of leaves set on the stalk about one inch below the blossom. 


\section{PLATE XXII}

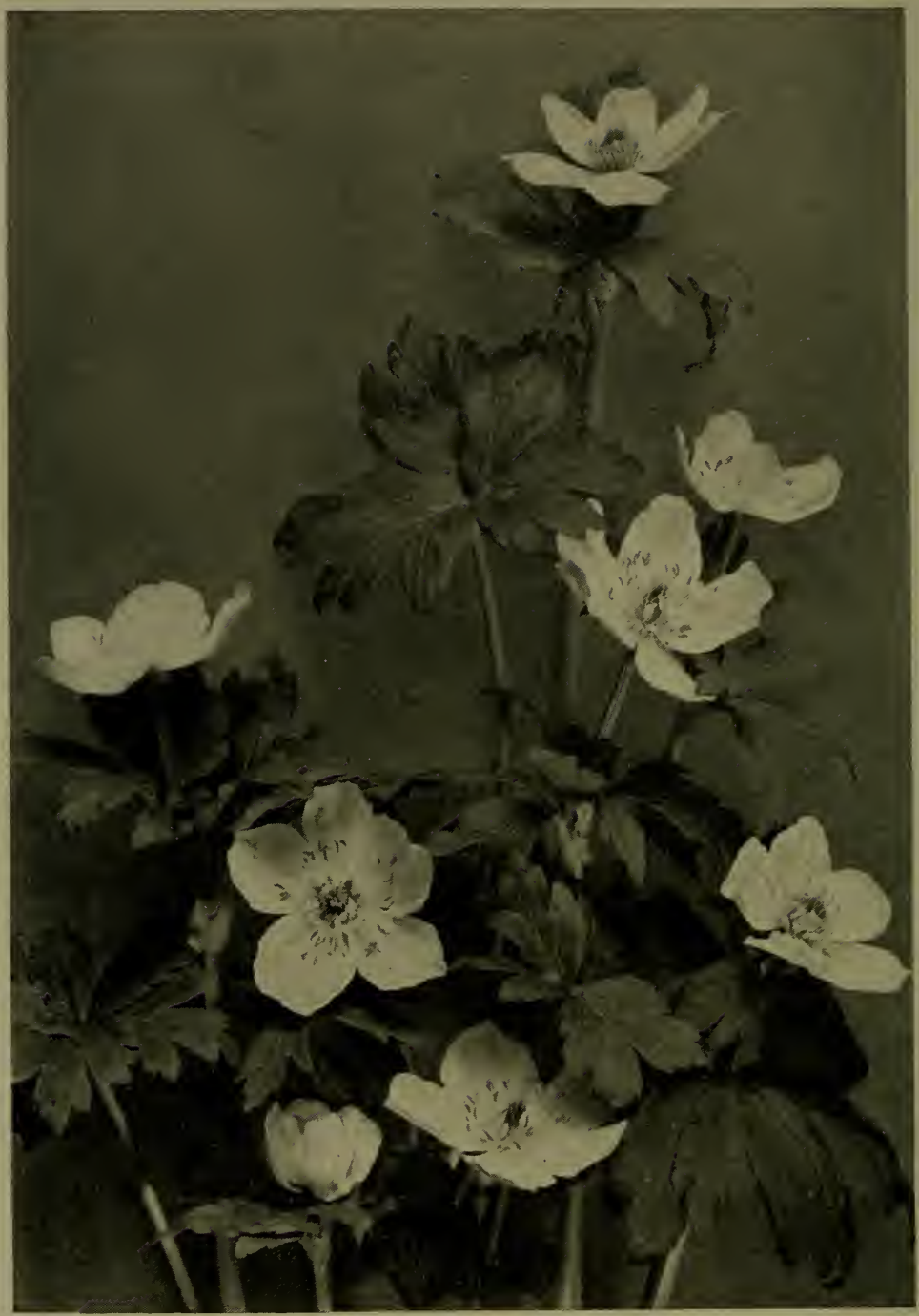

White Globe Flower

(Trollius laxus var. albiflorus) 
The White Globe Flower is frequently found growing up through the snow.

\section{RED BANEBERRY}

Actea rubra. Crowfoot Family

Stems: one to six feet high from a fascicle of short branching roots. Leaves: ternate, the divisions pinnate, with the lower ultimate leaflets sometimes again compound, ovate, sometimes obscurely three-lobed, toothed. Flowers: in oblong terminal racemes, sometimes divided towards the base, loose; petals oblong, obtuse. Fruit: berries red, oval, many-seeded.

The Red Baneberry is a perennial herb, not a shrub, and grows to the height of six feet, being a very large bushy plant. The foliage is abundant and coarsely veined, and the tiny flowers, which grow in oblong, close-set, terminal racemes, are feathery and delicate in appearance. This plant usually flourishes in the dense forest glades, where the dainty white blossoms and clusters of bright red berries adorning its slender stalks render it both attractive and conspicuous.

Actca rubra forma neglecta, or White Baneberry, is rather difficult to distinguish from the preceding species until the fruit ripens, when its berries will be found to be much larger than those of Actca rubra, a pure, waxy, chinawhite tinged with purple at the end, and growing on long slender green pedicels; whereas those of the Red Baneberry are, as its name denotes, a bright scarlet. The leaves of the White Baneberry are more pointed and more deeply cut than those of its sister plant, the white petals are square at the ends, and the flowers grow in long-shaped clusters. This plant is the Actca cburnea of Rydberg. 


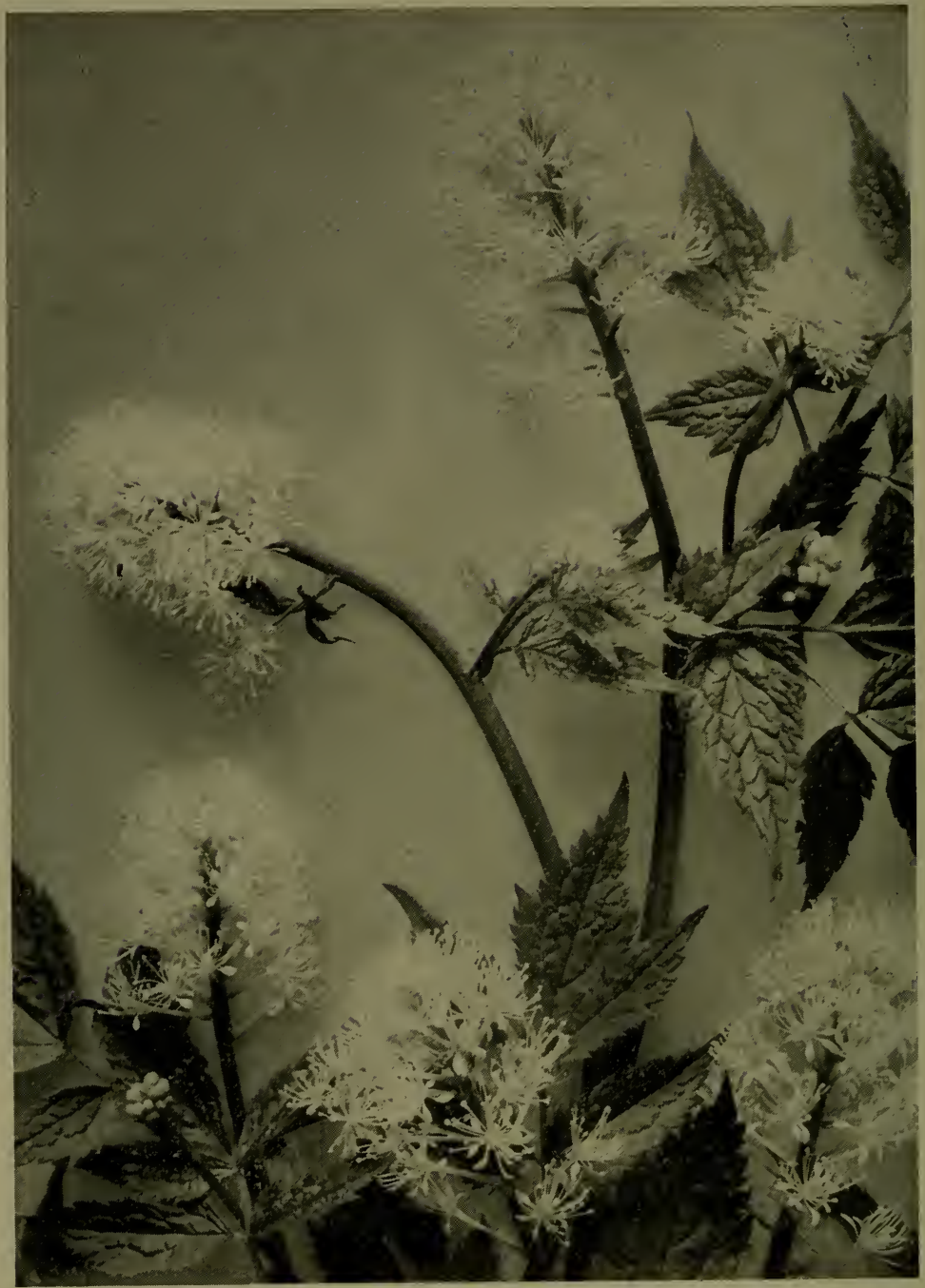

Red BaneberRy

(Actca rubra) 


\section{WHITE WHITLOW GRASS}

Draba incana. Mustard Family

Stems: hoary, pubescent. Leaves: oblong-lanceolate, nearly entire. Flowers: petals notched; style minute. Fruit: pods acute, twisted when ripe, on short erect pedicels.

A plant partaking of the appearance of a weed, and closely resembling a white mustard. It has lance-shaped, toothed leaves, and the petals are notched at the apex.

Draba lonchocarpa, or Long-podded Whitlow Grass, may be recognized by its long smooth pods, which are very narrow, and more or less twisted. It is a hairy plant and grows on rock ledges at great altitudes.

Draba prcalta, or Spring Whitlow Grass, is a common species which grows abundantly between four and six thousand feet.

\section{PENNY CRESS}

Thlaspi arvense. Mustard Family

Stems: erect, glabrous. Leaves: petioled, oblanceolate, dentate; stem-leaves oblong. Flowers: white, pedicels spreading or curved upward. Fruit: pods nearly orbicular when ripe, broad, very flat, notched at the apex, in long racemes; seeds rugose. Not indigenous.

Penny Cress very nearly resembles Shepherd's Purse, and the easiest way to distinguish between the two plants is to note that while the seed-pods of the latter are triangular in shape, those of the Penny Cress are nearly round, both being notched at the top. Then, also, the leaves differ: those of the Shepherd's Purse are deeply cut, and those of the Penny Cress are only slightly toothed. This is an introduced plant. 


\section{I34 White to Green and Brown Flowers}

\section{PEPPER GRASS}

Lepidium apetalum. Mustard Family

Stems: glabrous, wiry. Leaves: the basal ones pinnatifid, the upper ones smaller, dentate. Flowers: in long racemes. Fruit: seeds solitary in each cell, pendulous.

This plant is nearly scentless, and has compound basal leaves and small-toothed upper ones. The white flowers grow in long-shaped clusters, and the seed-pods are circular and minutely wing-margined at the top.

\section{SHEPHERD'S PURSE}

\section{Capsella Bursa-pastoris. Mustard Family}

Stems: branching. Leaves: mostly runcinate-pinnatifid, cauline, lanceolate, auricled at base. Flowers: small, white, in long loose racemes; petals four; sepals four. Fruit: pods cuneate-triangular, truncate above; seeds ten or twelve in each cell. Not indigenous.

This common little white-flowered plant grows all over the world in temperate zones and at various altitudes. Its tiny heart-shaped seed-purses have amused the children of many countries. It is closely related to Candytuft, to which it bears a strong resemblance. Sir Joseph Hooker once stated that in his opinion of all the weeds which cling to the skirts of husbandry, Shepherd's Purse would be the first to disappear if the soil were suddenly to be left untilled and deserted by man and beast. The quaint name of "Pickpocket" frequently applied to this plant betokens the suspicion that it steals the nutriment the farmer distributes to his crops. Shepherd's Purse has no scent or honey, and it fertilizes itself. This is an introduced plant. 


\section{NORTHERN ROCK CRESS}

Braya humilis. Mustard Family

Stems: erect, branching below. Leaves: spatulate, the lower obtuse, sharply dentate, the upper smaller and narrower, acute. Flowers: on ascending pedicels. Fruit: pods terete, glabrous, linear.

This plant closely resembles the Tansy Mustards. It has white, rarely pinkish flowers, and a basal rosette of coarsely toothed leaves, the upper leaves being narrow and evenmargined.

\section{WATER CRESS}

Radicula Nasturtium-aquaticum. Mustard Family

Aquatic, glabrous; root fibrous. Stems: stout, hollow, rooting at the decumbent base. Leaves: pinnate, leaflets rounded or elongated, the terminal ones largest. Flowers: petals white; sepals four, early-falling; stamens six; style short, thick. Fruit: pods divaricately spreading, seeds in two rows. Not indigenous.

Surely it is a libel to call this plant Nasturtium, which signifies " twisted nose," and is given to Water Cress simply because we are supposed to turn up our noses when we eat its acrid leaves. Those who go out to gather flowers will seldom pause to pick this insignificant plant, whose clusters of small white flowers grow close beside, or actually in, the streams and ponds, and whose only claim upon our attention lies in the pleasant pungent flavour of its leaves. This is an introduced plant.

\section{WHITE BITTER CRESS}

Cardamine pennsylvanica. Mustard Family

Stems: glabrous, erect, rather stout. Leaves: pinnately divided, the terminal segment oval and narrowed at the base, all toothed. Flowers: in corymbose racemes. Fruit: pods narrowly linear, erect when mature. 
This White Bitter Cress grows in wet places, and sometimes attains a height of two feet. It is a coarse plant with compound leaves, small white flowers, and very long narrow seed-pods which become erect at maturity.

Cardamine bellidifolia, or Alpine Bitter Cress, is a small plant two to five inches in height, which is found on the alpine summits. It has fibrous roots, little oval leaves growing on long slender stalks which branch out from the main stems, and terminal clusters of inconspicuous white flowers.

\section{STONY ROCK CRESS}

Arabis Holbollii. Mustard Family

Stems: erect, simple. Leaves: spatulate, petioled, entire or sparingly toothed; stem-leaves erect, clasping. Flowers: white or pinkish. Fruit: pods linear, drooping.

Growing out of a cluster of long-shaped leaves, the Stony Rock Cress has a tall stalk, up which many tiny narrow leaves cling. The flowers are small white, mauve, or pinkish bells, growing in a raceme. This plant, as its name indicates, is generally found in very dry stony places. It grows from eight to eighteen inches high, and has very long narrow seed-pods, which droop downwards.

Arabis hirsuta, or Hairy Rock Cress, is easily distinguished from the other Rock Cresses by its hairy stalks and leaves.

Arabis Drummondii, or Drummond's Rock Cress, is a handsome leafy species, with erect flat seed-pods.

Arabis glabra, or Smooth Rock Cress, has long toothed basal leaves, and even-margined stem leaves which are arrow-shaped at the base. The flowers are deep creamcolour. 


\section{ROUND-LEAVED SUNDEW}

Drosera rotundifolia. Sundew Family

Stems: slender, glabrous. Leaves: orbicular, spreading on the ground. Flowers: in a one-sided raceme, four to twelve flowered. Fruit: seeds fusiform, pointed at both ends.

This bog-herb has a quantity of small round leaves that grow on flat stalks, and are covered with reddish glandular hairs which secrete a fluid that entraps insects. This fluid is exuded in tiny drops at the tips of the hairs, so that the plant always appears to be covered with dew and is very sticky. The white flowers grow in a one-sided cluster, and open usually in sunshine, but only during a very few hours of the day, sometimes not opening at all for several days in succession. The Sundews grow chiefly in wet places, preferably in sphagnum bogs.

"What's this I hear

About the new carnivora?

Can little plants

Eat bugs and ants

And gnats and flies?

A sort of retrograding;

Surely the fare

Of flowers is air,

Or sunshine sw'eet;

They shouldn't eat,

Or do aught so degrading."

It is perfectly true that the Sundew not only catches insects with its sticky fluid, so like a liquid gum, but also actually digests and absorbs the nutriment thus derived from the soft parts of its victims. When a fly caught by the glutinous globules touches one of the glandular hairs, or we might almost call them tentacles, an irritation is set up communicable through the leaf substance to the other 
hairs or tentacles, which at once begin to bend in over the unfortunate insect and imprison it within a network from which escape is impossible. Then the glands begin to exude an acid digestive fluid, and the Sundew proceeds to batten and fatten upon the meat in its larder. Inorganic substances (with the exception of those which are required by plants for their sustenance, such as phosphate of ammonia, carbonate of ammonia and nitrate of ammonia) do not affect the Sundew, which possesses such extremely delicate sensibilities that it instantly recognizes the difference between organic and inorganic matter. Darwin's experiments with this plant have shown us that infinitesimal particles of vegetable or animal substance will cause the hairs to bend over, while a grain of sand leaves them uninfluenced.

Droscra longifolia, or Long-leaved Sundew, has erect elongated spatulate leaves narrowed into a long stalk, which are covered with glandular hairs like the preceding species. The white flowers grow in a terminal cluster.

\section{LEPTARRHENA}

Leptarrhena amplexifolia. Saxifrage Family

Stems: six to fifteen inches high, rigid, with one or two small leaves with sheathing petioles. Leaves: obovate coarsely serrate above the middle, attenuate below to a short-winged petiole, which is dilated and sheathing at the base. Flowers: numerous, in bracted paniculate racemes; petals five, entire, linear, white; calyx campanulate. Fruit: carpels purple-red, divergent.

A very handsome plant, with closely clustered flowerheads and thick glossy leaves. In seed it is remarkable for its rich purple-red appearance. It grows in quantities near many alpine streams. 


\section{WESTERN BOYKINIA}

Boykinia occidentalis. Saxifrage Family

Stems: slender, erect or declined from a creeping somewhat woody caudex. Leaves: round-cordate, incisely lobed, on slender petioles with dilated base. Flowers: in elongated paniculate cymes. Fruit: a capsule.

This plant has a creeping woody rootstock, and alternate leaves which are rounded and heart-shaped at the base. The flowers grow in branching flat-topped clusters, have a bell-shaped calyx, and five white early deciduous petals which narrow below to a long claw.

\section{COMMON SAXIFRAGE}

Saxifraga bronchialis. Saxifrage Family

Stems: one to six inches high, ascending, slender, producing short branchlets. Leaves: coriaceous, lanceolate, mucronate, sessile, with a broad base finely ciliate. Flowers: few, in an open corymb on slender pedicels ; petals oblong, white, marked with red spots.

Frequently the traveller will find immense rocky slopes literally covered with the pretty little blossoms of this Saxifrage, which may easily be recognized by the bright red spots that mark its five white petals. It is a low-growing species, the flower-stalks seldom exceeding six inches in height, and being much branched and reddish in colour. The tiny narrow leaves are very stiff, - indeed, a noticeable characteristic of the whole plant is its rigid nature. The name is derived from sa.rum, " a rock," and frango, "I break," and the Germans call it Steinbrech, because it grows so thickly in the crevices of the rocks that it is supposed to disintegrate them by its growth. All the Saxifrages are much visited by flies and bees, and 


\section{I40 White to Green and Brown Flowers}

"Scarce less the cleft-born wild-flower seems to enjoy Existence, than the winged plunderer That sucks its sweets."

Saxifraga cermua, or Nodding Saxifrage, is a creamywhite flower, more rare than many of its sister Saxifrages, and growing from four to eight inches high. The traveller will at once be struck by the little bright red bulbs that grow in the axils, where each upper leaf is attached to the stalk; and by this characteristic, as well as by its lower palm-like leaves, the Nodding Saxifrage may be readily known. It grows among the rocks at very high altitudes.

Saxifraga Lyallii, or Lyall's Saxifrage, has a creeping caudex and is sparingly branched. There are two tall very branching white Saxifrages which to the ordinary eye closely resemble one another, namely, Lyall's Saxifrage and Tall Saxifrage, and a careful reference to the descriptions of each should be made in determining a particular plant.

Lyall's Saxifrage is the smaller of the two plants, and is less branching; its leaves grow in a cluster at the base, are rounded, deeply toothed, and often tinged and streaked with red. The flowers, which are very numerous, are white. A special distinguishing feature is the seed-pods, three or four in number, which develop in the centre of each flower in a cluster, and are red, with very pointed erect beaks.

Saxifraga nutkana, or Tall Saxifrage, grows erect from a fleshy caudex. The Tall Saxifrage is a larger and handsomer plant than Lyall's species. It is also more branching, growing from six to eighteen inches high, and covered with many tiny white blossoms, each with a bright orange or red spot at the base of the blade. The leaves grow in a cluster at the base, from the centre of which the flower-stalks 
PLATE XXIV

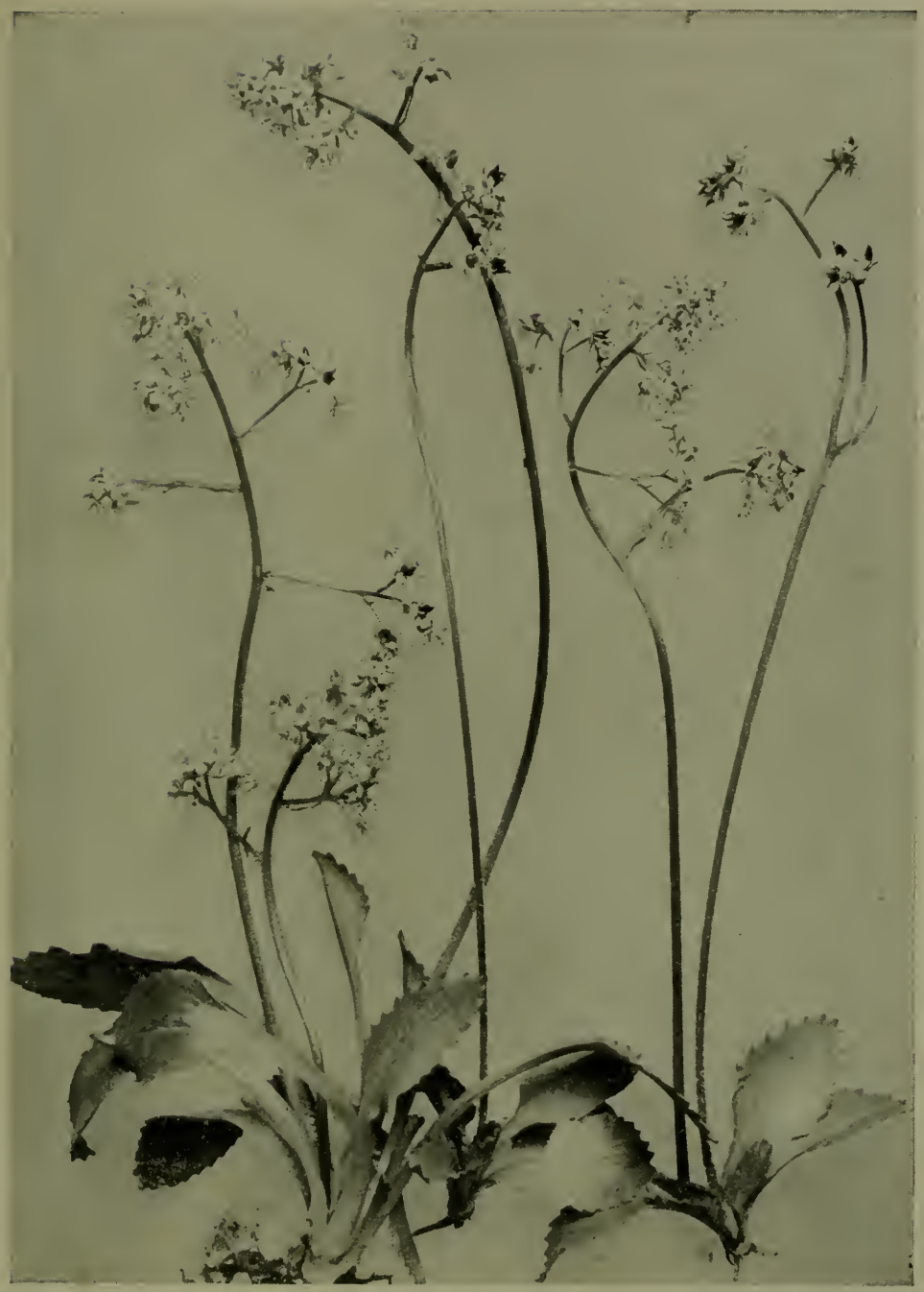

Alpine Saxifrage

(Saxifraga nivalis) 
spring; they are hairy, long-shaped, and sharply toothed. You can best distinguish the Tall Saxifrage from Lyall's species by the leaves, which in the former are spatulate and long-shaped and in the latter rounded. The Tall Saxifrage also generally has small bulblets growing below the flowers.

Saxifraga nivalis, or Alpine Saxifrage, is a plant which grows at extremely high altitudes, as well as on the lower mountain slopes. It, too, has a cluster of leaves at the base, rounded and toothed at the top and narrowing down sharply towards the root. The flowers grow in handsome compact heads, and the stalks, usually quite bare of leaves, are reddish and not straight. The seed-pods are purple-red and spreading.

Saxifraga Mertensiana, or Spotted Saxifrage, has a bulblike rootstock, and propagates by bulblets in the axils of the leaves which latter are rounded, heart-shaped at the base, lobed and toothed, being very large and broad. The white petals of the flowers have two yellow spots near the base and the capsule is oval and inflated.

Sa.rifraga cstizalis, or Purple-bracted Saxifrage, has kidney-shaped leaves which are deeply cordate at the base and coarsely toothed. The white flowers grow in a loose open panicle, and the bracts on the stalks are quite purplish.

Saxifraga ccspilosa, or Tufted Saxifrage, has slender running stems and short branchlets. It forms dense tufts as large as eighteen inches in diameter on the ground. The leaves are pale yellowish-green, thin, fan-shaped and deeply three-to-five cleft. The white flowers are large in comparison with the size of the plant and the narrow entire bracts and three-lobed leaves grow on the flowering stalks.

Saxifraga adscendens, or Wedge-leaved Saxifrage, has wedge-shaped three-toothed leaves growing in basal rosettes, 


\section{PLATE XXV}

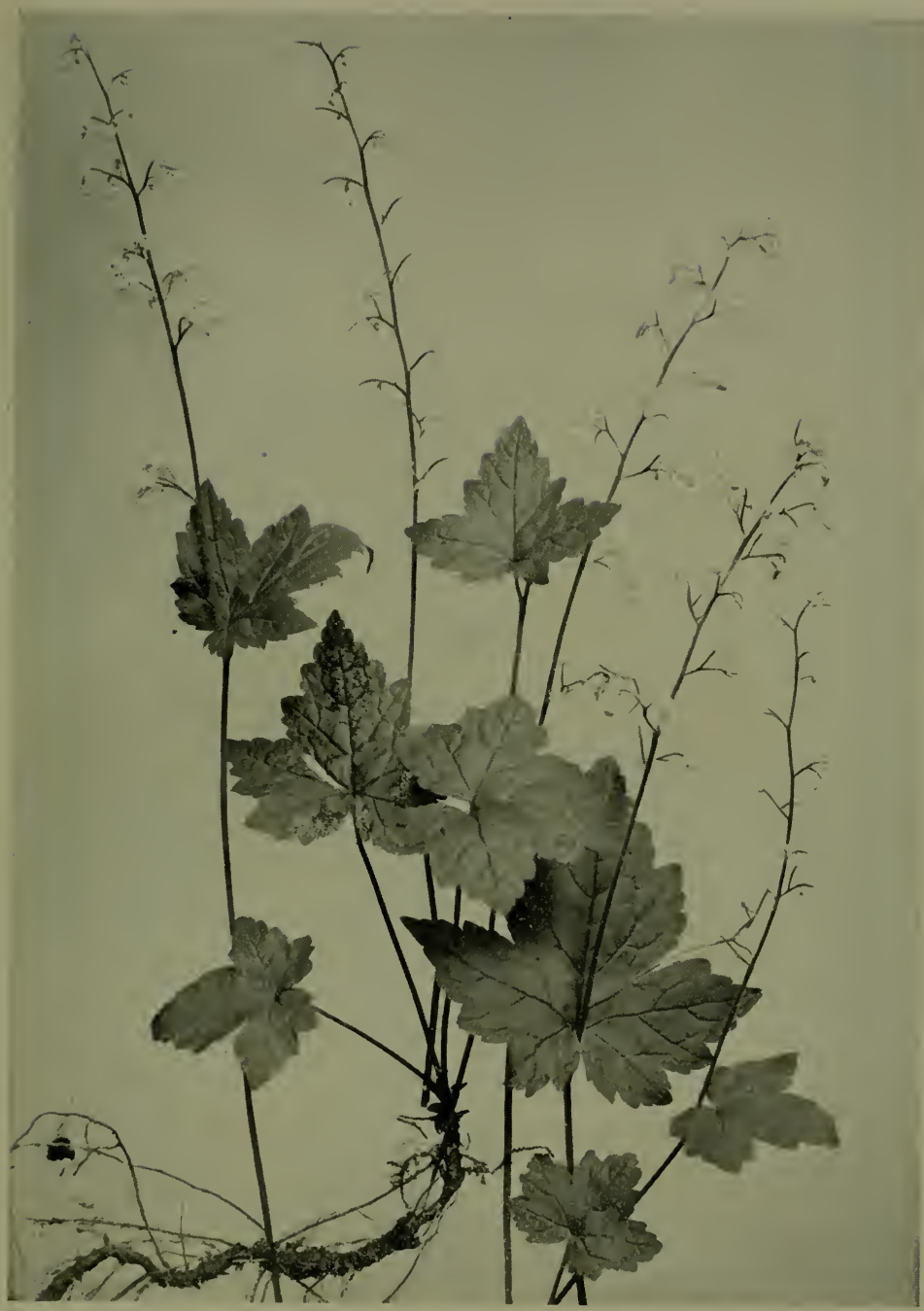

NANCY-CVER-THE-GROUND

(Tiarclla unifoliata) 


\section{I44 White to Green and Brown Flowers}

and branching stalks. The white petals are also wedgeshaped.

Saxifraga rivularis, or Alpine Brook Saxifrage, has kidney-shaped basal leaves which are three-to-five lobed, and narrow upper leaves. The flowers which terminate the slender stalks are erect. This plant is found on the alpine summits and near running water.

\section{NANCY-OVER-THE-GROUND}

Tiarella unifoliata. Saxifrage Family

Stems: slender, spreading from running rootstocks. Leaves: simple, cordate, acute, obscurely five-to-seven lobed on long fine petioles. Flowers: numerous, in a narrow panicle; calyx cleft to near the base; petals five, filiform; stamens ten.

The tiny feathery flowers of this plant are found in great quantities in the mountains. Their large heart-shaped leaves appear to carpet the ground about three inches above the soil in the localities where they abound, and their white masses of delicate bloom have earned for them the name of "Foam-Flower." The Latin name Tiarella means " a little tiara," and refers to the shape of the capsule, while unifoliata refers to the one leaf on the flower-stalk.

\section{OVAL-LEAVED ALUM ROOT}

Heuchera oz'alifolia. Saxifrage Family

Stems: six to eighteen inches high, leafless. Leaves: ovate, cordate, crenate. Flowers: a greenish-cream, small, in terminal panicles, spikelike, cylindrical, two to four inches long; calyx campanulate; petals filiform or none. Fruit: seeds hispid.

This plant is usually found in very dry stony places, among the rocks or on gravelly slopes. It is remarkable for its tall stiff stalks, which are leafless and end in a dense spike of closely-set creamy flowers. The leaves are green 


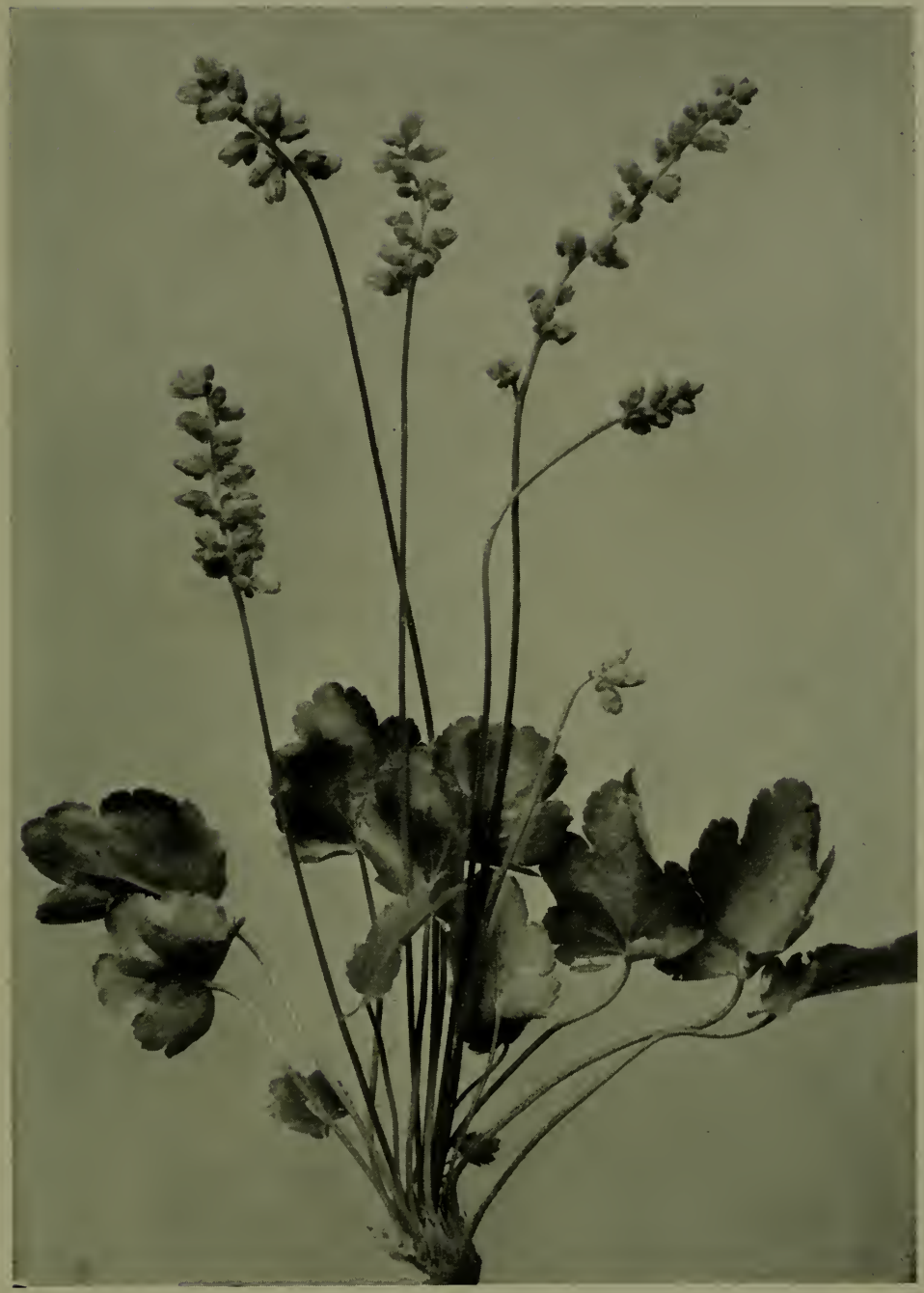

Oval-Leaved Alum Root (Heuchera ovalifolia) 


\section{I46 White to Green and Brown Flowers}

and reddish, round, and with wavy margins. It is a peculiar but not an attractive plant.

Heuchera glabra, or Smooth Alum Root, has roundish lobed leaves which are doubly toothed; the cream-coloured flowers grow in a loose branching cluster and the style is much exserted.

Heuchera glabclla, or Bristly Alum Root, differs from the foregoing species in having leathery round-toothed leaves, the teeth of which are bristly at the apex and have marginal hairs. The white flowers are small and grow in a loose branching spike, each branch being subtended by a hairy bristly bract.

\section{TELLIMA}

Tellima grandiflora. Saxifrage Family

Stems: hispid-pubescent, from short tufted rootstocks. Leaves: round-cordate, three-to-nine lobed, coarsely toothed, on long petioles. Flowers: cream-colour, with rose-pink margins, on very short reflexed pedicels; calyx thick, cylindraceous, with turbinate tube and short, triangular, erect lobes, inflated; petals laciniately cut into filiform segments, narrowed below to a short claw.

A plant that is easily recognized by means of its long stalks, bearing numerous round cream-coloured or green blossoms, which are set closely against it, their edges rose colour and deeply fringed. It grows from one to two feet high and has quantities of foliage, the leaves being large, rouncled, and lobed, with fine white hairs standing up all over them.

\section{MITREWORT}

\section{Mitella Breweri. Saxifrage Family}

Stems: pubescent with brownish hairs. Leaves: round-cordate, three-to-five lobed, toothed. Flowers: small, green, in simple spicate racemes; calyx short, campanulate; petals pectinately pinnate, with filiform pinnæa. 
PLATE XXVII

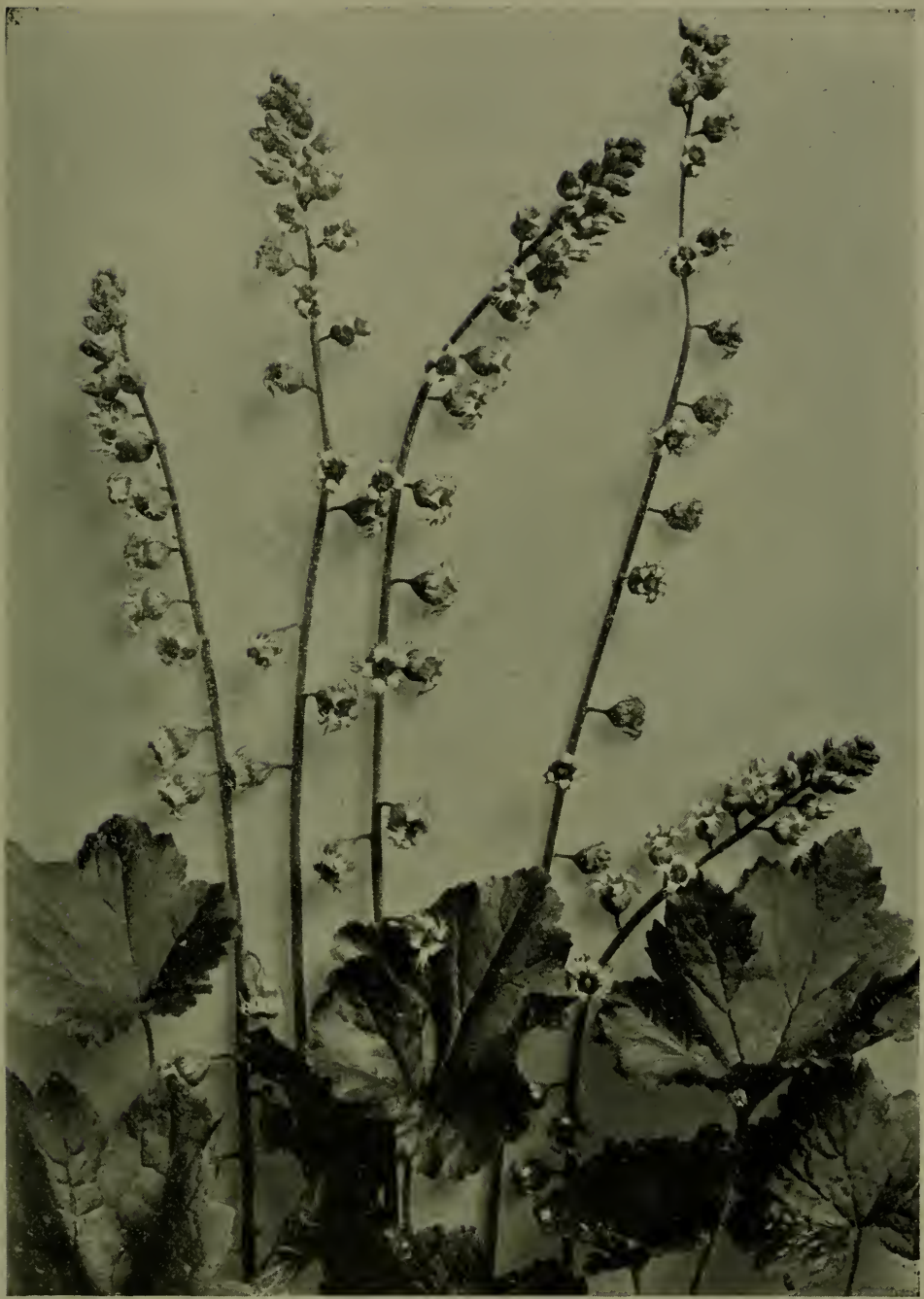

Tellima

(Tellima grandiflora) 


\section{I48 White to Green and Brown Flowers}

The Mitrewort is one of the few absolutely green flowers that grow in the mountains; it derives its name of Mitclla, or Bishop's Cap, from the form of the seed-pod. It differs from Nancy-over-the-ground, first, in that its blossoms are much more fragile and green, and secondly, in that it is more leafy and is covered with tiny hairs.

Mitella muda, or Bishop's Cap, has a stoloniferous stem. The leaves are circular and deeply cordate at the base, bluntly toothed at the edge, and covered on both sides with scattered hairs. The greenish flowers are similar to those of the preceding species.

Mitella pentandra, or Five-stamened Mitrewort, has leaves which are circular in outline, but usually three-to-five lobed and unequally toothed at the edge. The flowers have a bell-shaped calyx with very short lobes and compound petals. The five stamens are placed opposite the petals.

Mitella trifida, or Alpine Mitrewort, is sparingly covered with coarse white hairs, and the flowers grow in a one-sided cluster, each tiny stalk being subtended by a white bract. Both the bell-shaped calyx and the three-toothed petals are white.

\section{MARSH GRASS OF PARNASSUS}

Parnassia montanensis. Saxifrage Family

Stems: bearing one clasping ovate leaf. Leaves: ovate, petioled, obtuse at the apex, cordate at the base. Flowers: elliptic, few-veined; petals five; stamens numerous, in clusters at the base of each petal.

Why "Grass," and why "of Parnassus"? Assuredly the traveller will be surprised when he finds what kind of flower bears this exceedingly unsuitable name, for the Grass of Parnassus is like a delicate white buttercup, the veins in its petals being strongly marked, and numerous stamens 
growing at the base of every blade. Each stalk is clasped by a single little round leaf, and a mass of smooth glossy foliage grows close to the ground. These basal leaves are much curled up, and in low-lying marshes and other wet places you will find them in profusion during the month of July. Perhaps it was the velvety petals of the Grass of Parnassus that caused Emerson to ask:

"Why Nature loves the number five, And why the star-form she repeats?"

For in this particular mountain wild flower the five petals and the star-form are both especially conspicuous.

Parnassia finibriata, or Fringed Grass of Parnassus, is also very common in moist places among the mountains. It closely resembles the plant already described, but may be clearly distinguished from it, because the petals are conspicuously fringed towards the base and have fine marginal hairs.

Parnassia parviflora, or Small Grass of Parnassus, resembles the mountain species, but has smaller flowers, and may always be distinguished by the fact that the basal leaves are oval, and not heart-shaped, but narrowed into a slender stalk.

Parnassia Kotzcbuci, or Alpine Grass of Parnassus, is a tiny species, only a few inches high, and is found at great altitudes.

\section{BRISTLY GOOSEBERRY}

Ribes setosum. Saxifrage Family

Stems: with infra-axillary spines, slender, spreading, sometimes none; bristles usually numerous, scattered. Leaves: slender-petioled, broadly ovate in outline, five-lobed, the lobes incised-dentate. Flowers: greenish-white; calyx-tube cylindric, longer than the oblong lobes; 
stamens not exserted. Fruit: a giobose purple berry, pulpy, the calyx persistent on its summit, sparingly bristly or often glabrous.

The bush on which this Bristly Gooseberry grows is found in the shady woods, and attains an average height of three feet. The flowers are greenish-white and very insignificant, and the fruit consists of a small purple pulpy berry, which is sweet to the taste.

Ribes lacustre, or Swamp Gooseberry, has branches covered with slender spines. The leaves are nearly circular in outline, heart-shaped, deeply five-to-seven lobed, and toothed at the edges; while the green or purplish flowers grow in loose racemes. The fruit is a purplish-black berry covered with weak bristles.

Ribcs hudsonianum, or Black Currant, has smooth erect branches, and leaves, which are round-cordate, three-to-five lobed, coarsely toothed, and resinous-dotted beneath. The racemes of white flowers are dense, and the fruit is a smooth black berry.

\section{BIRCH-LEAVED SPIREA}

Spirca lucida. Rose Family

Stems: erect, reddish, woody, one to two feet high. Leaves: lower ones small, obovate; upper ones oval, acutish, unequally serrate on short petioles. Flowers: cream-colour in compound corymbs; petals five, rounded.

A small bushy shrub with woody stems bearing large showy, fluffy flower-heads, flattened on the top and formed of numerous tiny cream-coloured blossoms tinged with pink.

It frequently grows by the side of mountain roads and at the edge of trails, where the bright sunshine brings it out to perfection. The red woody stems break off with a sharp snap, and the scent of the flowers is extremely sweet. 


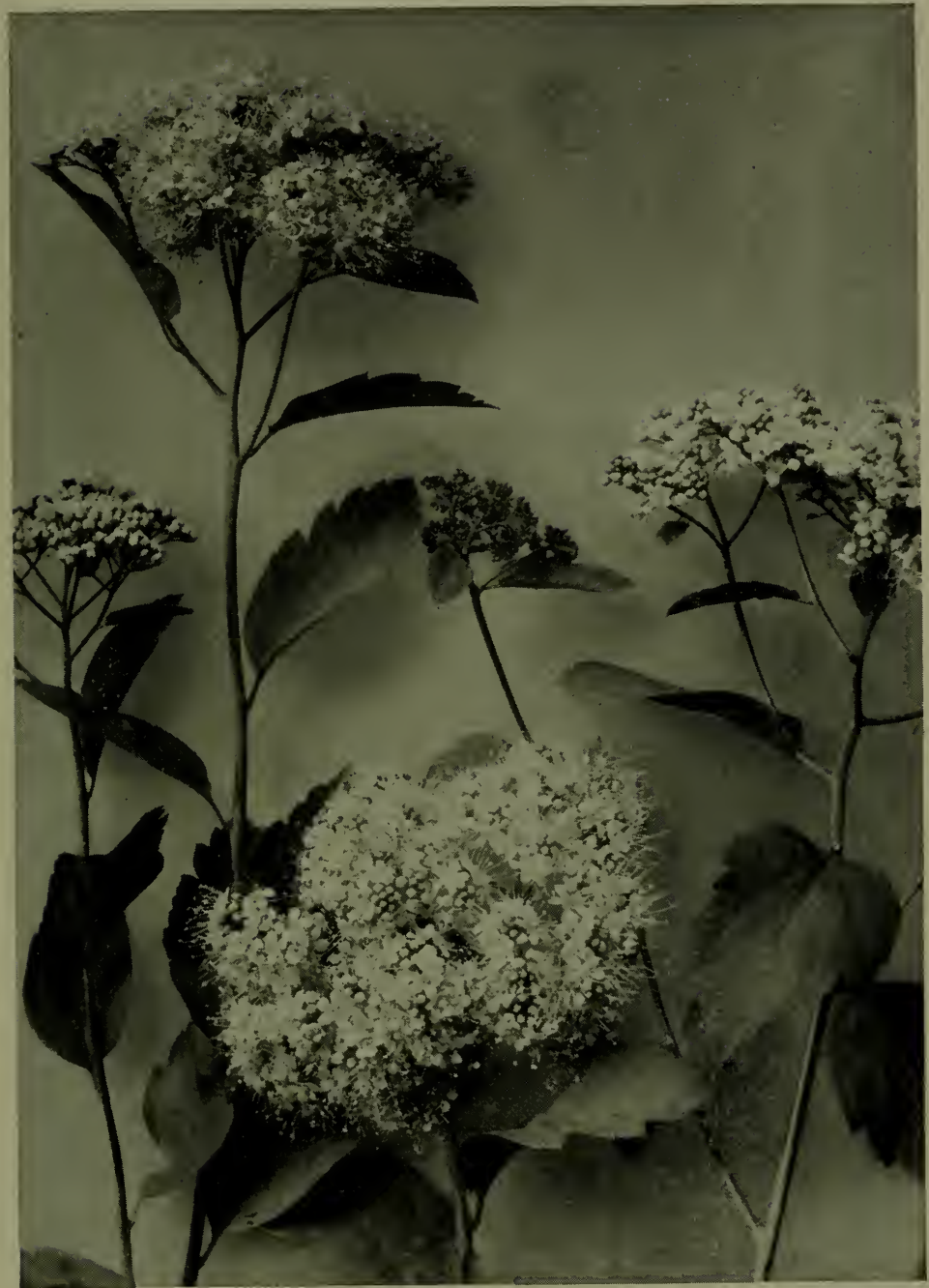

Birch-Leaved Spirea

(Spirca lucida) 


\section{I52 White to Green and Brown Flowers}

\section{GOAT'S BEARD}

Aruncus sylicster. Rose Family

Stems: erect, bracted. Leaves: long-petioled, pinnate, three-toseven foliolate; leaflets ovate, lanceolate, thin, acute at the apex, rounded at the base, sharply doubly serrate. Flowers: in long, slender, panicled spikes, erect or spreading.

This tall, shrub-like, perennial herb is quite unmistakable, as it grows from three to ten feet high in the rich soil of the wet valleys, and bears numerous long showy plumes of closely clustered, minute, creamy flowers rising above its masses of luxuriant strongly veined foliage. Thus the Goat's Beard is both decorative and conspicuous. The tiny flowers are formed of a five-lobed calyx and five petals, and the seeds are very small and shining.

\section{ALPINE SPIR蚱A}

\section{Lutkea pectinata. Rose Family}

Stems: cespitose, creeping, very leafy; flowering stems erect. Leaves: trifoliolate, persistent; leaflets deeply lobed. Flowers: in short terminal racemes; calyx-lobes ovate, acute, equalling the tube; petals obovate.

A lovely trailing plant, its flowers growing to an average height of four inches, in elongated heads, each individual tiny blossom having six white petals and a number of yellow stamens. The leaves grow close to the ground, resembling a large moss, and are deeply fringed and fern-like. The shoots of the plant run along the ground; the stems of the flowers are brittle and woody.

\section{COMMON SERVICEBERRY}

\section{Amelanchier florida. Rose Family}

A shrub three to six feet high, more or less tomentose-pubescent when young, at length glabrate throughout and somewhat glaucous. Leaves: 


\section{PLATE XXIX}

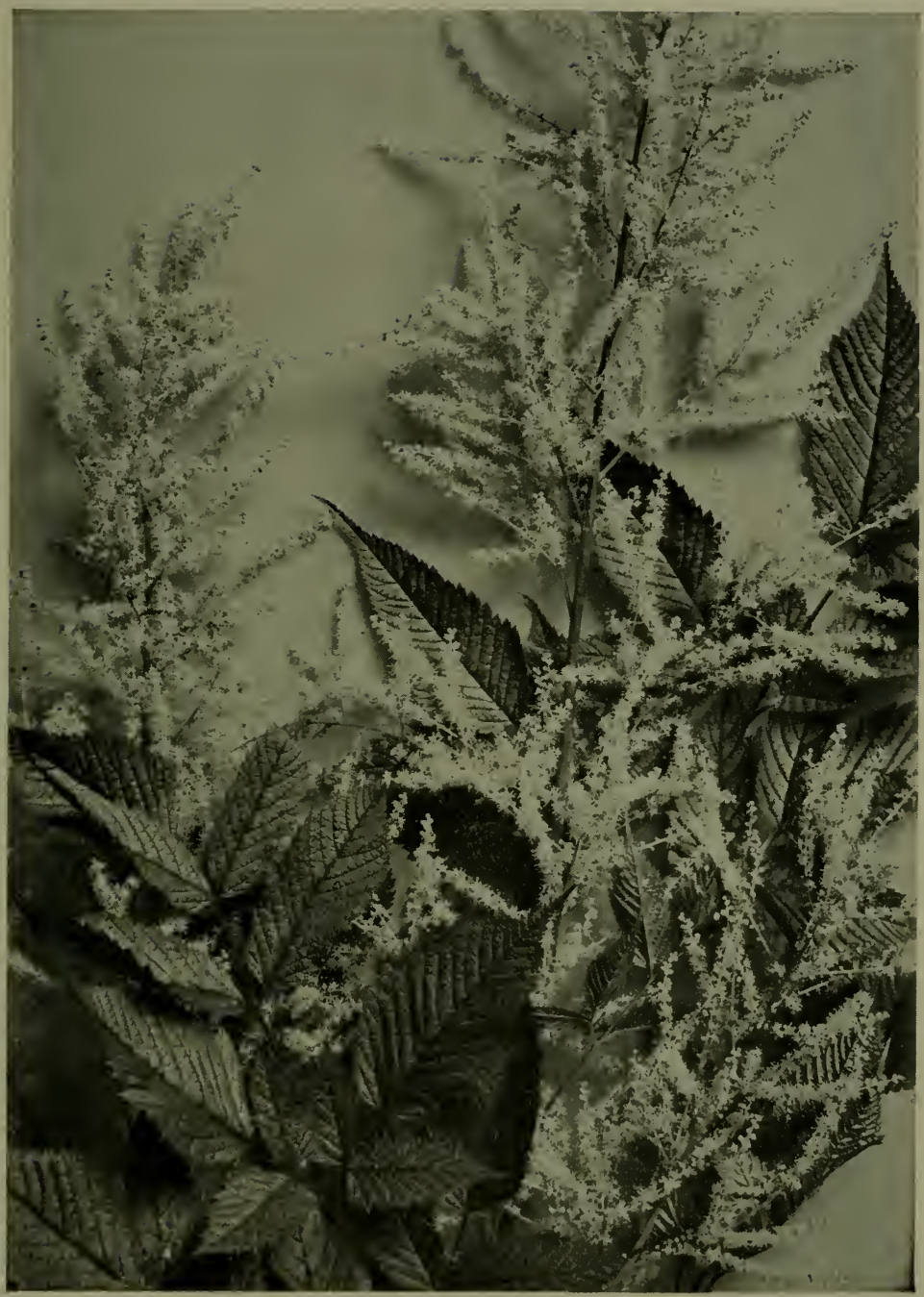

Goat's Beard

(Aruncus sylvester) 


\section{54 White to Green and Brown Flowers}

thick, broadly elliptic or orbicular, very obtuse, and often truncate at the apex, rounded or subcordate at the base, coarsely dentate above the middle. Flowers: white, in short racemes, rather dense; petals five, oblanceolate, cuneate. Fruit: a globose pome, purple with a bloom, sweet.

This is the low pearly-flowered shrub which grows on the sandy banks and flats, and which the Indians call Saskatoon, for its sweet purple berries form a staple article of food with them during the months of July and August. It somewhat resembles the Western Choke Cherry, but its greenishwhite blossoms are larger and have long narrow petals; also its leaves are oval, with flattened ends, and are very coarsely toothed above the middle, whereas those of the Western Choke Cherry are oblong, pointed, and finely toothed all round the edges. The bark of the little branches of the Serviceberry is reddish, and the young leaves are quite pale and downy underneath.

Amelanchier Cusickii, or Thick-leaved Serviceberry, grows on stony hillsides, and has, as its name denotes, thicker leaves than the preceding species.

\section{WILD STRAWBERRY}

\section{Fragaria glauca. Rose Family}

Stems: running, and forming new plants. Leaves: tufted from the root, villous-pubescent with spreading hairs, long-petioled, palmatelytrifoliate; leaflets oval, obtuse, dentate, the terminal one cinneate. Flowers: of five petals, cymose; scape with appressed pubescent and generally glaucous leaies. Fruit: red, ovoid.

Nearly every one will easily recognize the blossoms of the Wild Strawberry plant. "Doubtless God could have made a better berry, but doubtless God never did." This is equally true of the fragrant scarlet fruits on the mountain side as of their cultivated cousins in the garden.

Fragaria bracteata, or Wood Strawberry, is a small 
PLATE XXX

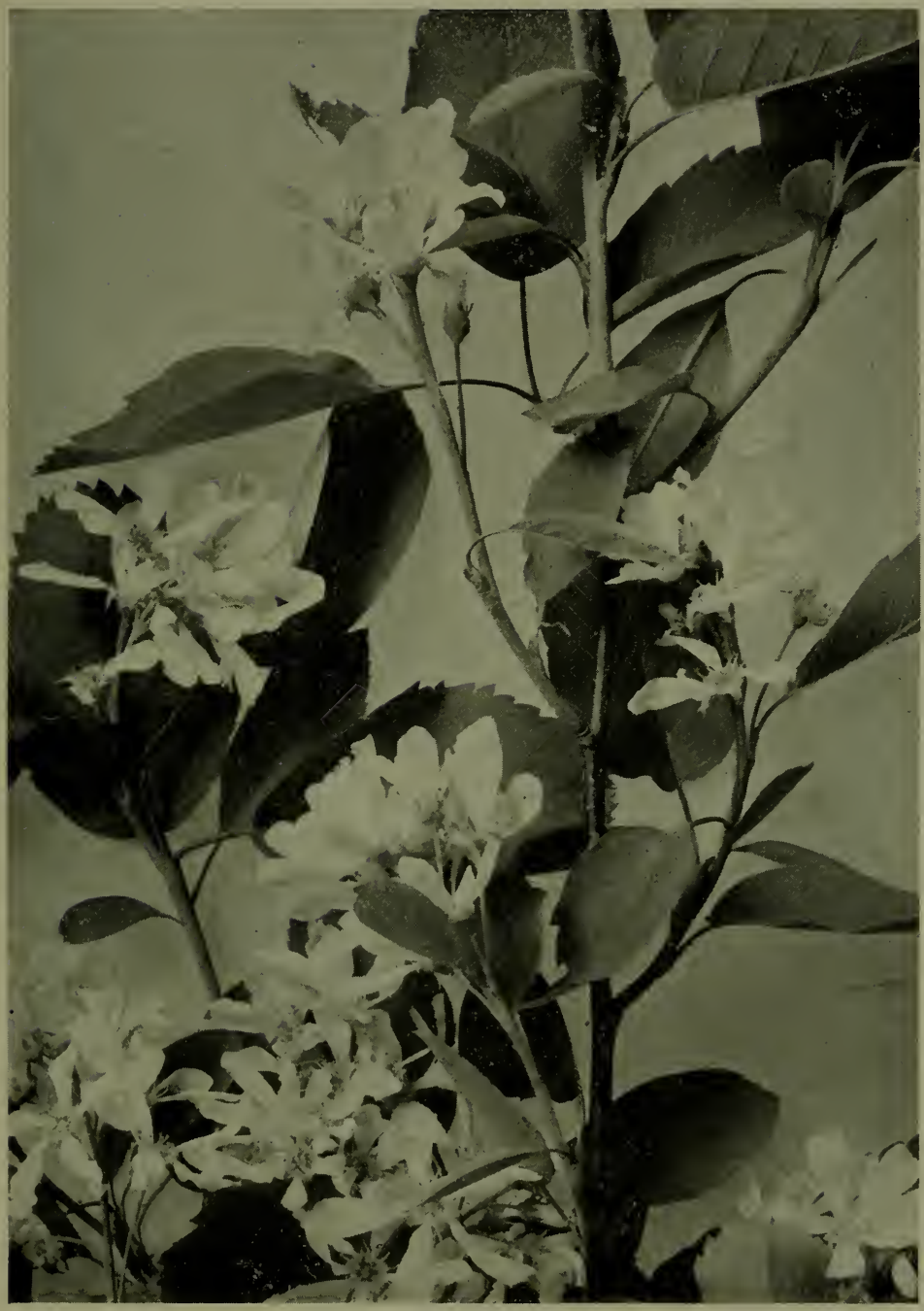

Common Serviceberry (Amelanchier florida) 


\section{I56 White to Green and Brown Flowers}

species, marked by conspicuous bracts, which grows on the forested hillsides.

\section{TALL CINQUEFOIL}

Potentilla arguta. Rose Family

Stems: erect, stout, simple below. Leaves: seven-to-eleven foliolate; leaflets ovate, obtuse at the apex,- the terminal one cuneate, the others rounded at the base. Flowers: cyme strict, close; calyx densely pubescent.

Cinquefoils are very numerous in the mountain regions, and somewhat resemble buttercups. The Tall Cinquefoil is a fine showy plant, its white flowers growing in a cluster and having five petals; the stalks are hairy and have many leaves growing up them. All the other Cinquefoils have yellow flowers except $P$. palustris, which has purple ones.

\section{CAPBERRY}

\section{Rubus parziflorus. Rose Family}

Erect, branched, very slightly bristly. Leaves: petioled, simple, cordate at the base, three-to-five lobed, the lobes acute, the middle one slightly longer than the others, all coarsely and unequally serrate. Flowers: white, few, corymbose, terminal; calyx-lobes tipped with a long slender appendage. Fruit: depressed-hemispheric, edible, red when ripe.

The five snow-white crinkled petals of the Capberry look very frail and pretty when seen amid the dense coarse foliage of this large bushy shrub. The flower is formed like a miniature white rose, and has numerous tiny stamens set around the convex receptacle in which are inserted the carpels that ultimately ripen into drupelets and form an aggregate red fruit.

The Capberry grows abundantly in the

"High-wooded hollows, where serenely rest

The lazy clouds, like giants in repose." 
PLATE XXXI

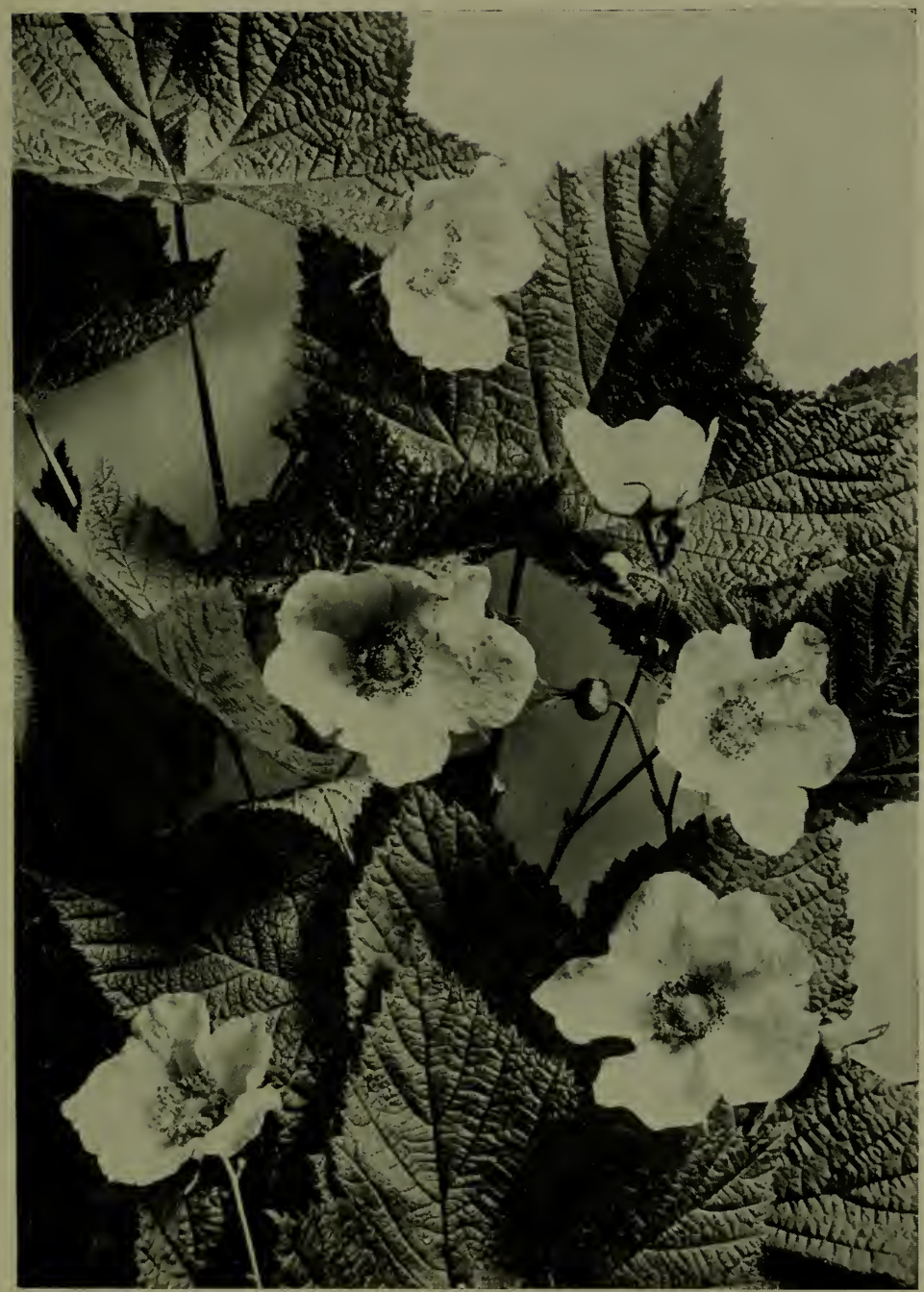

CAPBerR

(Rubus parviflorus) 
Rubus strigosus, or Red Rasplerry, has shrubby stems usually densely covered with weak glandular bristles, the older ones bearing small hooked prickles. The leaves are three-to-five lobed, rounded at the base and sharply toothed. The white flowers grow in a loose raceme and the fruit is sweet, red and very juicy.

Rubus triflorus, or Dwarf Raspberry, has spineless stems growing from six to eighteen inches high, and trifoliate leaves the segments of which are nearly smooth and pointed, the terminal one being wedge-shaped. The white flowers usually grow in clusters of three on a slender stalk and the fruit is a purplish-red berry.

Rubus pedatus, or Creeping Raspberry, is a charming little vine that trails over the rocks and creeps along the ground, gemming the moss with its starry five-petalled white flowers, in the centre of each of which grow many fine yellow-tipped stamens. The leaves are divided into three (or very rarely five) leaflets, which are coarsely toothed at the edges. The fruit consists of a cluster of from three to six red juicy globules, pressed together and held in a cup of tiny green leaves. The long lithe strands of this pretty, delicate vine are most decorative, as many white flowers and scarlet fruits may be gathered at the same time upon a single. trailing branch.

\section{WOOD NYMPH}

\section{Dryas octopetala. Rose Family}

Stems: prostrate, woody at the base, branched. Leaves: oblongovate, coarsely crenate-toothed, obtuse at each end, green and glabrous above, densely white-canescent beneath, the veins prominent. Flowers: white. Fruit: plumose, conspicuous.

These beautiful white-cupped flowers grow close to the ground, generally in dry sandy or rocky places. They do 
PLATE XXXII

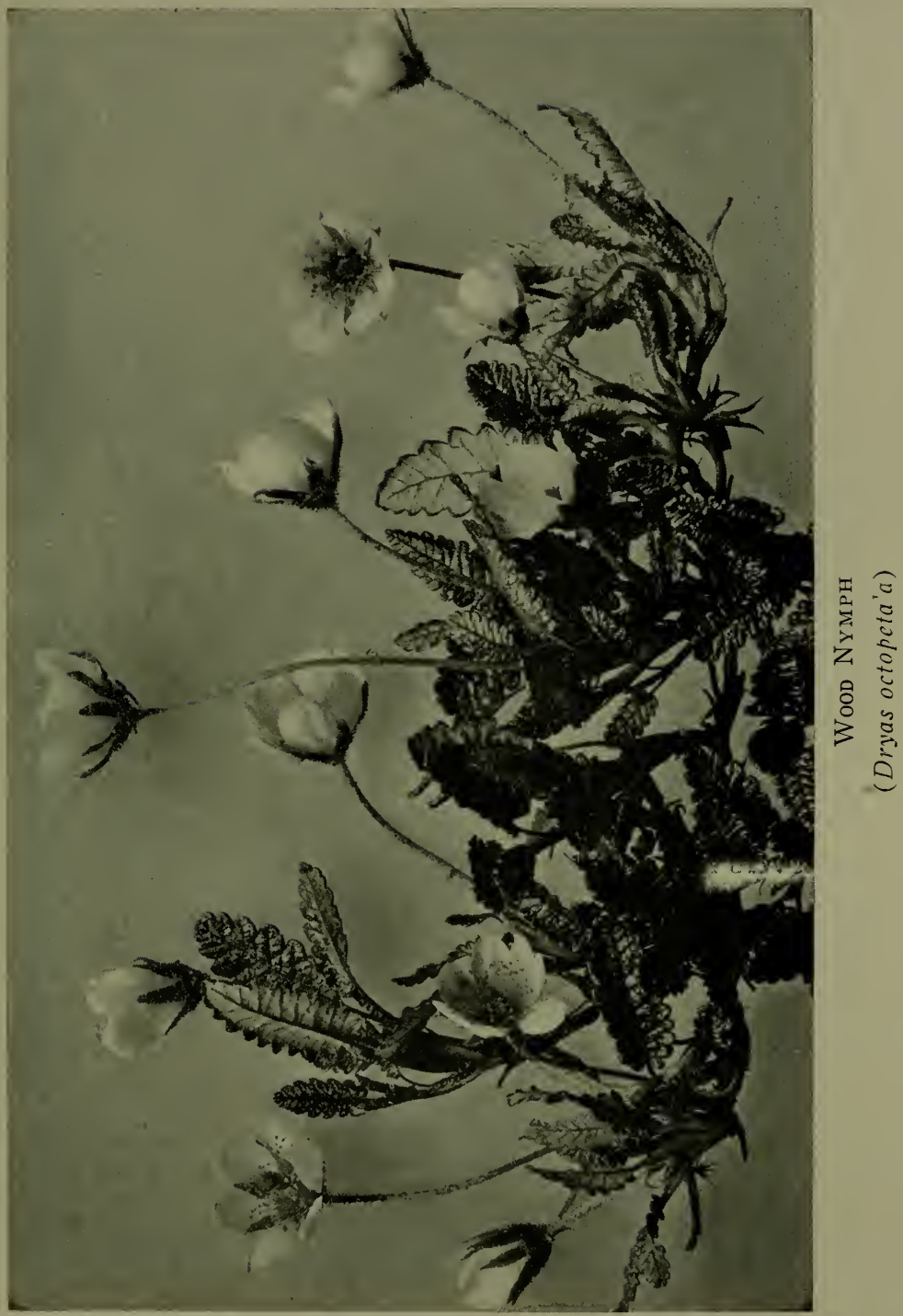


not always have eight petals, as their name would indicate, but may be found with from six to twelve on a single flower. The name Dryas is from the Latin, signifying "a wood-nymph," and certainly the velvety petals of this dainty plant, growing amid a mass of silver-backed leaves, are sufficiently exquisite to warrant the appellation.

\section{WHITE CLOVER}

\section{Trifolium repens. Pea Family}

Perennial, branching at the base, rooting at the nodes. Leaves: long-petioled; stipules narrow, lanceolate; leaflets obcordate, denticulate. Flowers: white or pinkish, in loose, globose long-peduncled heads; calyx teeth acuminate. Fruit: pods four-seeded. Not indigenous.

This Common or Honeysuckle Clover is widely distributed. It may be quickly recognized by the fact that the leaves all grow on long stalks directly from the root. This is an introduced plant.

Trifolium hybridum, or Alsatian Clover, is much taller and has numerous leaves growing up on its flower-stalks. The latter species is frequently pinkish in hue.

Clovers have a very close association with our childhood, those happy bygone days when we plucked out single flowers from the rounded heads and sucked the slender tubes of nectar; and always the sweet scent of the Clover blossoms recalls to us the well-remembered fields where

\footnotetext{
"South winds jostle them, Bumble-bees come, Hover, hesitate, Drink, and are gone."
}

This is an introduced plant. 


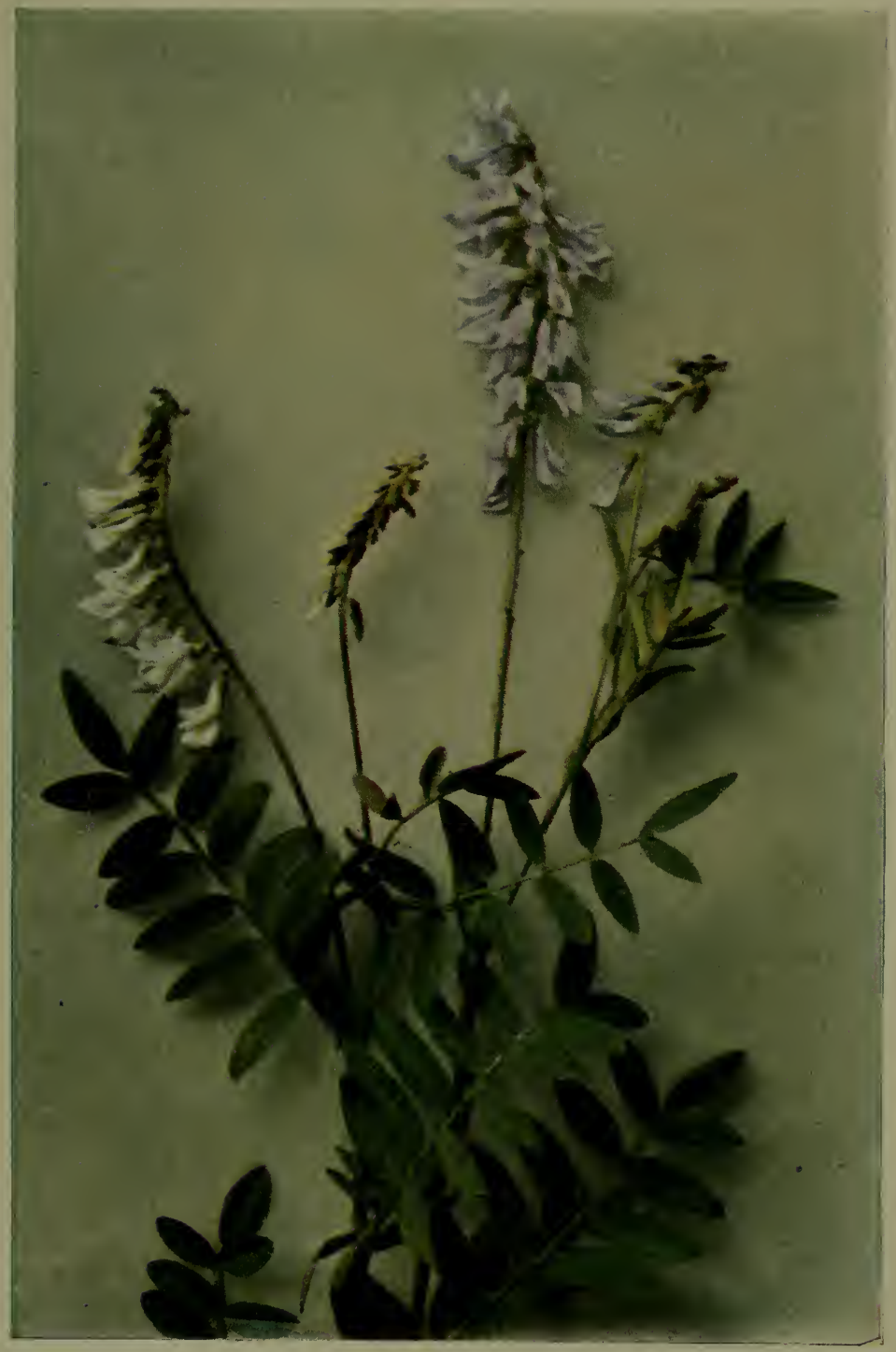

Purple Heydarum (Hedysarum boreale) White Heydsarum (Hedysarum sulphurescens) 



\section{INDIAN MILK VETCH}

Astragalus aboriginorum. Pea Family

Stems: finely glabrate, erect, branched. Leaves: leaflets linear, obtuse; stipules ovate, acute, foliaceous. Flowers: white, tinged with mauve in loose racemes; peduncles longer than the leaves; calyx blackish-pubescent, its teeth subulate. Fruit: pods semi-elliptic.

One of the least attractive of the Vetches. It has a long yellow root which is collected in the spring by the Stony and Cree Indians as an article of food. The leaves are whitish and rather silky, and the flowers are chiefly noticeable by reason of their dark-hued hairy calyx.

Astragahıs tenellus, or Loose-flowered Milk Vetch, has ascending stems and thin oblong pale green leaflets, which are blunt at the apex and narrowed at the base. The flowers are yellowish-white, sometimes tinged with pink, and grow in loose spike-like racemes. The pod is stalked, papery and pointed at both ends.

\section{LENTIL VETCH}

\section{Phaca americana. Pea Family}

Stems: erect, nearly simple, tall, leafy, subglabrous. Leaves: leaflets seven-to-nine paired, ovate, and elliptic-oblong; peduncles equalling the leaves. Flowers: white, in a loose raceme. Fruit: pods oblong, acute at each end, black-hairy.

A handsome plant, growing one to two feet high, with many leaves, and big white-flowered heads. It has no tendrils, but grows very stiffly with thick upright stalks.

\section{WHITE HEDYSARUM}

Hedysarum sulphurescens. Pea Family

This is a white species of $H$. borcale, a full description of which will be found in the Blue to Purple Section. 


\section{PLATE XXXIII}

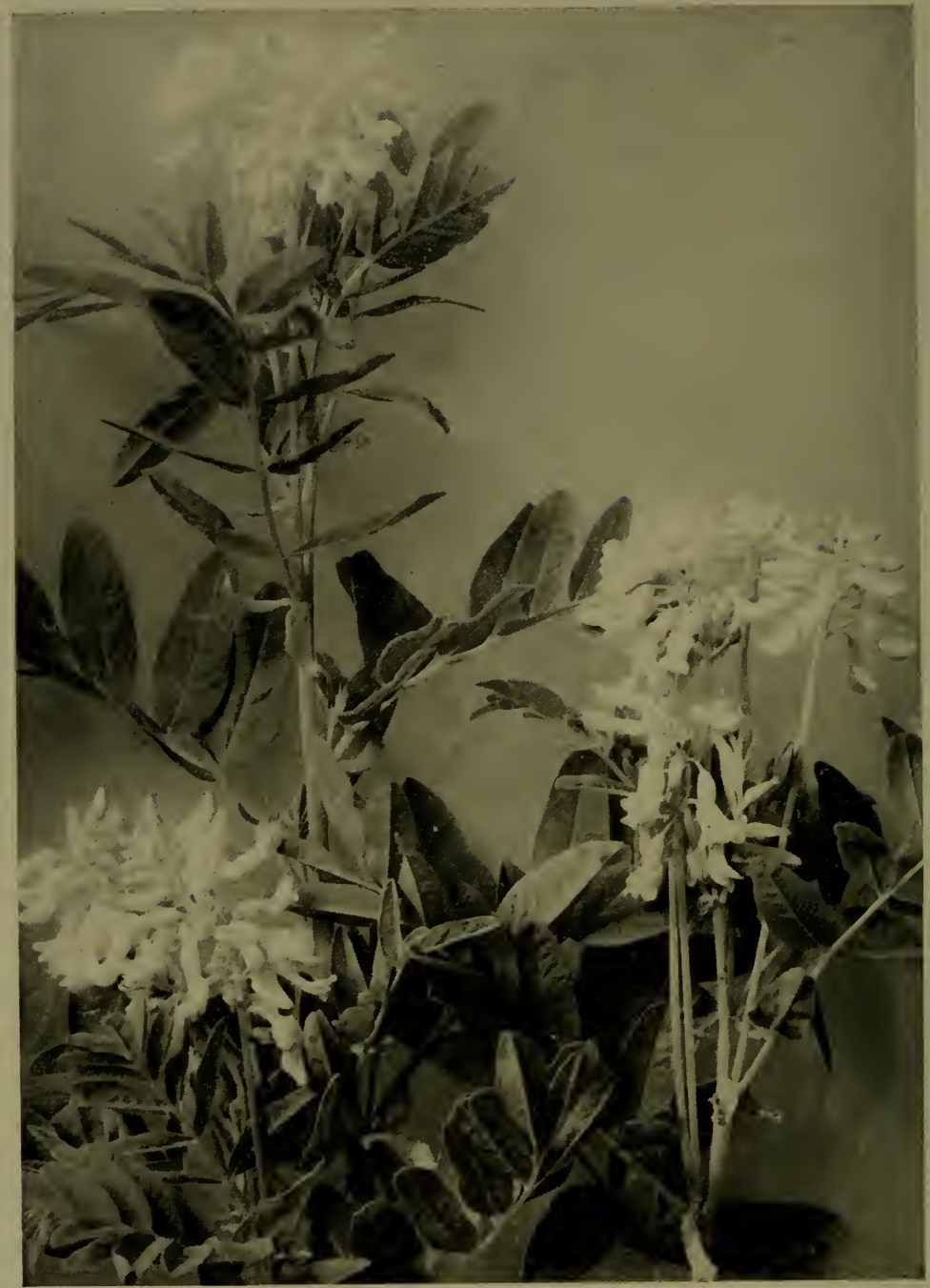

Lentil Vetch

(Phaca americana) 


\section{WHITE VETCHLING}

Lathyrus ochroleucus. Pea Family

Stems: slender, trailing. Leaves: leaflets in three to four pairs, ovate, distinctly petioled; stipules semi-cordate, entire. Flowers: sevento-ten flowered, ochroleucus; tendrils branched. Fruit: pods oblonglinear, sessile, glabrous.

No one wandering in the summer woods can mistake this dainty, delicate White Vetchling, which trails along the ground, climbs over fallen trees, and twines its tiny branching tendrils about the shrubs beside which it grows. The flowers resemble those of the common garden green pea.

\section{WHITE GERANIUM}

Geranium Richardsonii. Geranium Family

Stems: erect with slender branches, one to three feet high. Leaves: deeply five-to-seven-cleft, lobes sharply incised. Flowers: petals entire, hirsute at base; sepals glandular, pilose.

This Geranium is almost invariably white, but very occasionally it is purple-red. The plant is a handsome one, tall, with rich foliage and fine flowers.

\section{WATER FENNEL}

Callitriche palustris. Water Starwort Family

An aquatic herb. Stems: submerged ones linear, bifid at the apex; floating ones obovate, obtuse, dotted with stellate scales. Fruit: compressed, lobed, winged only towards the apex, separated by a deep groove.

This plant is found chiefly in running water, or growing in the mud. It has minute flowers and a lobed winged fruit. 


\section{I64 White to Green and Brown Flowers}

\section{MOUNTAIN LOVER}

Pachistima Myrsinites. Staff Tree Family

Stems: densely branched. Leaves: opposite, ovate or lanceolate, cuneate at the base, the upper half serrate. Flowers: in axillary cymes.

A low evergreen shrub with numerous branches and very pretty foliage. The leaves are smooth and oblong, and the tiny greenish-brown flowers grow in the axils of the leaves.

\section{CANADA VIOLET}

Viola canadensis. Violet Family

Stems: glabrous, six inches to two feet high. Leaves: cordate, pointed, serrate; stipules entire. Flowers: petals white, tinged and veined with purple, sometimes nearly mauve-pink; spur very short; stigma beakless.

One of the most beautiful of the many violets which grow in the mountains, its lovely white petals, purple-shaded on the back, giving forth a delicate fragrance, and its tall leafy stems bearing aloft many blossoms. Usually it is found in the moist mossy woods, where it flourishes luxuriantly; but it also grows on the open alpine meadows, though here its stalks are not so tall, nor its flowers so large, as they are in the shade of the pines and firs. The Canada Violet continues to bloom from June until September.

\section{ALPINE WILLOW-HERB}

Epilobium alpinum. Erening Primose Family

Stems: erect with elongated internodes. Leaves: ellipical, petioled, slightly repand-denticulate, obtuse. Flowers: terminal in the upper axils. Fruit: a slender many-seeded capsule.

This small Willow-herb, which grows at the high altitudes, is almost invariably white, though very rarely it has pinkish flowers. The leaves are pale green and the green 
PLATE XXXIV

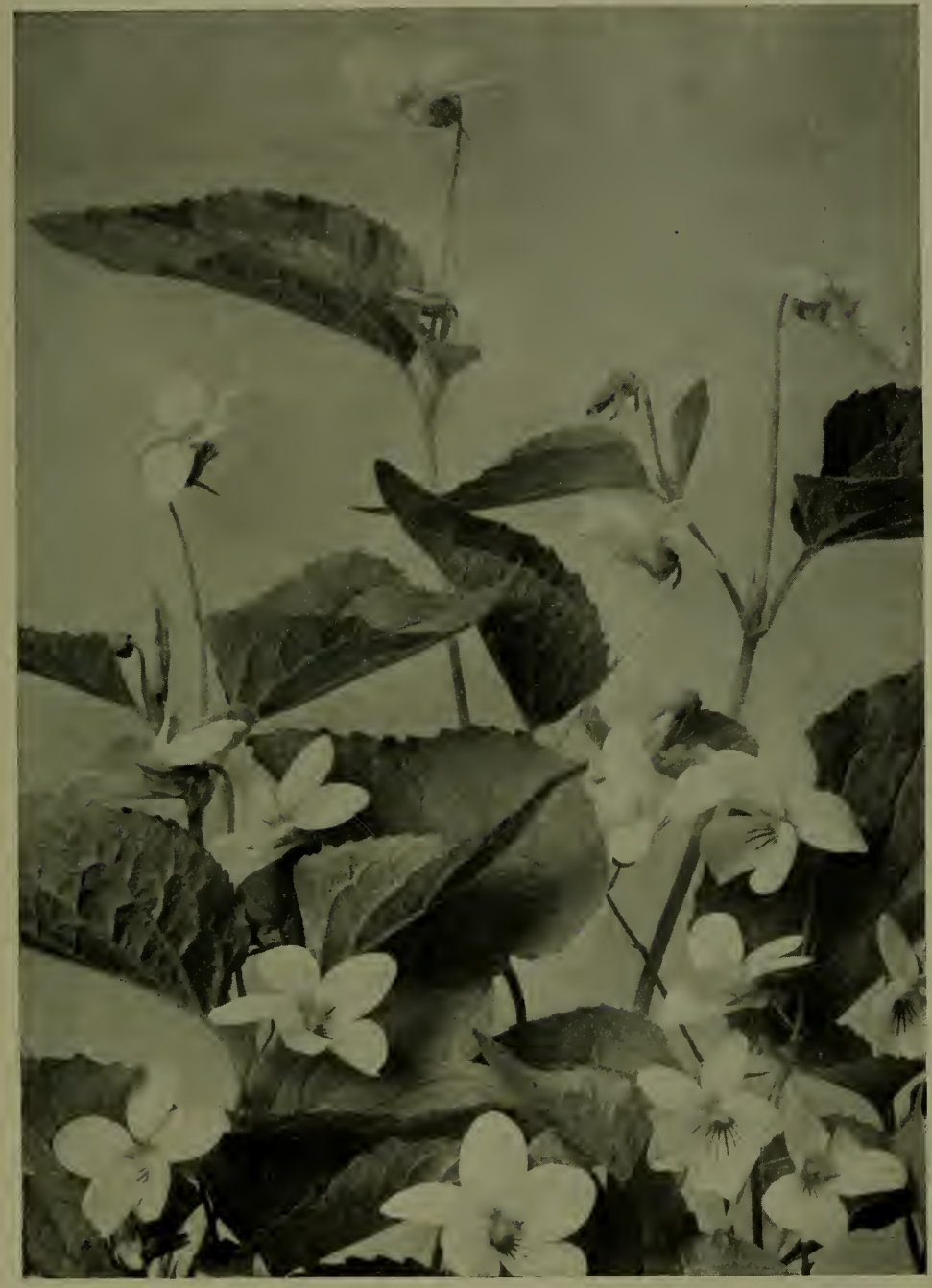

Canada Violet

(Viola canadensis) 
seed-pods are tinged with red, while the smooth seeds are tufted with long hairs at the ends.

\section{PACIFIC ENCHANTER'S NIGHTSHADE}

Circaa pacifica. Evening Primrose Family

Stems: glabrous, simple. Leaves: ovate, rounded or cordate at the base, acute, repandly-denticulate. Flowers: calyx with a very short tube. Fruit: capsule obovate, two-valved, with a simple erect seed in each cell.

This Pacific Coast species of Circæa is a perennial herb, and grows from six to twelve inches high from a small tuber. It has thin, broad leaves, and the small white flowers grow in racemes without bracts. The seeds are hispid with hooked hairs.

Circca alpina, or Small Enchanter's Nightshade, has weak, branching stems, and small white or reddish flowers growing in a slender raceme subtended by minute bracts. The leaves are heart-shaped, shining and coarsely toothed, and the bur-like fruit is covered with weak hooked hairs. The names of these plants are somewhat misleading; they neither resemble the Nightshades, nor do they suggest enchantment. Many hundred years ago Dioscorides described a plant named after Circe, the enchantress so skilled in the use of poisonous herbs, and that name was accidentally transferred to these rather insignificant little flowers which grow in the dense forests.

\section{SPIKED WATER MILFOIL}

\section{Myriophyllum spicatum. Water Milfoil Family}

Submerged leaves: in whorls of fours and fives, dissected into capillary divisions. Floral leaves: ovate, entire or serrate, usually shorter than the flowers, or sometimes none. Flowers: white, in spikes; petals four; stamens eight. Fruit: splitt:ng at maturity into four bony, one- 
seeded, indehiscent carpels, which are rounded on the back, with a deep wide groove between them, smooth, or very rarely slightly rugose.

This is an aquatic herb, with submerged, spreading, thready leaves set in whorls of four or five round the thick stems. Sometimes it has floral leaves that are very small and usually shorter than the blossoms. The name Myriophyllum is from the Greek and means "myriad-leaved." The flowers are minute and white-petalled and grow in tiny interrupted spikes.

\section{BOTTLE BRUSH}

Hippuris vulgaris. Water Milfoil Family

Stems: slender, glabrous. Leaves: linear or lanceolate, acute, sessile, in crowded verticles of six to twelve, more or less sphacelate at the apex. Flowers: small, axillary; calyx-limb minute, entire; petals none; stamen one, with a short thick filament and comparatively large twocelled anther dehiscent by lateral slits. Fruit: a small, one-celled, oneseeded drupe.

This is also an aquatic herb, with slender erect stems, bearing circles of from six to twelve narrow leaves in the axils, and curious tiny flowers which have no petals and only one stamen inserted on the margin of the calyx. The plant grows from eight to twenty inches high.

Hippuris montana, or Mountain Mare's Tail, is a tiny species growing only two to four inches high, and has narrow pointed leaves in whorls and an oval fruit.

\section{WILD SARSAPARILLA}

Aralia nudicaulis. Ginseng Family

Stems: scarcely rising out of the ground, smooth. Leaves: compound, leaflets oblong-ovate, pointed, serrate. Flowers: in umbels.

The somewhat woody stems of this plant are extremely short and have a single long-stalked compound leaf, and a 
shorter naked flower-stalk bearing usually three umbels of numerous little greenish flowers. The long horizontal root is very aromatic, and is often sold as a substitute for the genuine Sarsaparilla; while the fruit is dark purple and berry-like.

\section{DEVIL'S CLUB}

Fatsia horrida. Ginseng Family

Stems: stout, two to twelve feet high, decumbent at the base, leafy at the summit, very prickly throughout. Leaves: palnately lobed. Flowers: the greenish-white capitate umbels in a long dense raceme; calyx-teeth obsolete; petals five, valvate in the bud; stamens five, alternate with the petals; filaments filiform. Fruit: drupaceous.

A tall shrub consisting of a single stout stem covered with long sharp spines, which are extremely poisonous. It usually grows about six or eight feet high, and has huge palm-like leaves, which are also prickly. The flowers grow in a dense cluster at the top of the stem, and in time turn into bright red berries.

This plant should be carefully avoided in the forests. It has been rightly named "Devil's Club," since no human being may touch it with impunity.

\section{CRISP-LEAVED SWEET CICELY}

Osmorhiza obtusa. Parsley Family

Stems: glabrois. Leaves: ternately compound, leaflets ovate, acuminate, the teeth mucronate. Flowers: in few-rayed umbels. Fruit: with prominent caudate attenuation at base, ribs equal.

This plant has pretty fern-like leaves, thick anise-scented roots which are edible, and very ephemeral flowers, whose white wistful faces look up at one from the flat-topped clusters.

Osmorhiza diraricata, or IVestern Sweet Cicely, is a 
PLATE XXXV

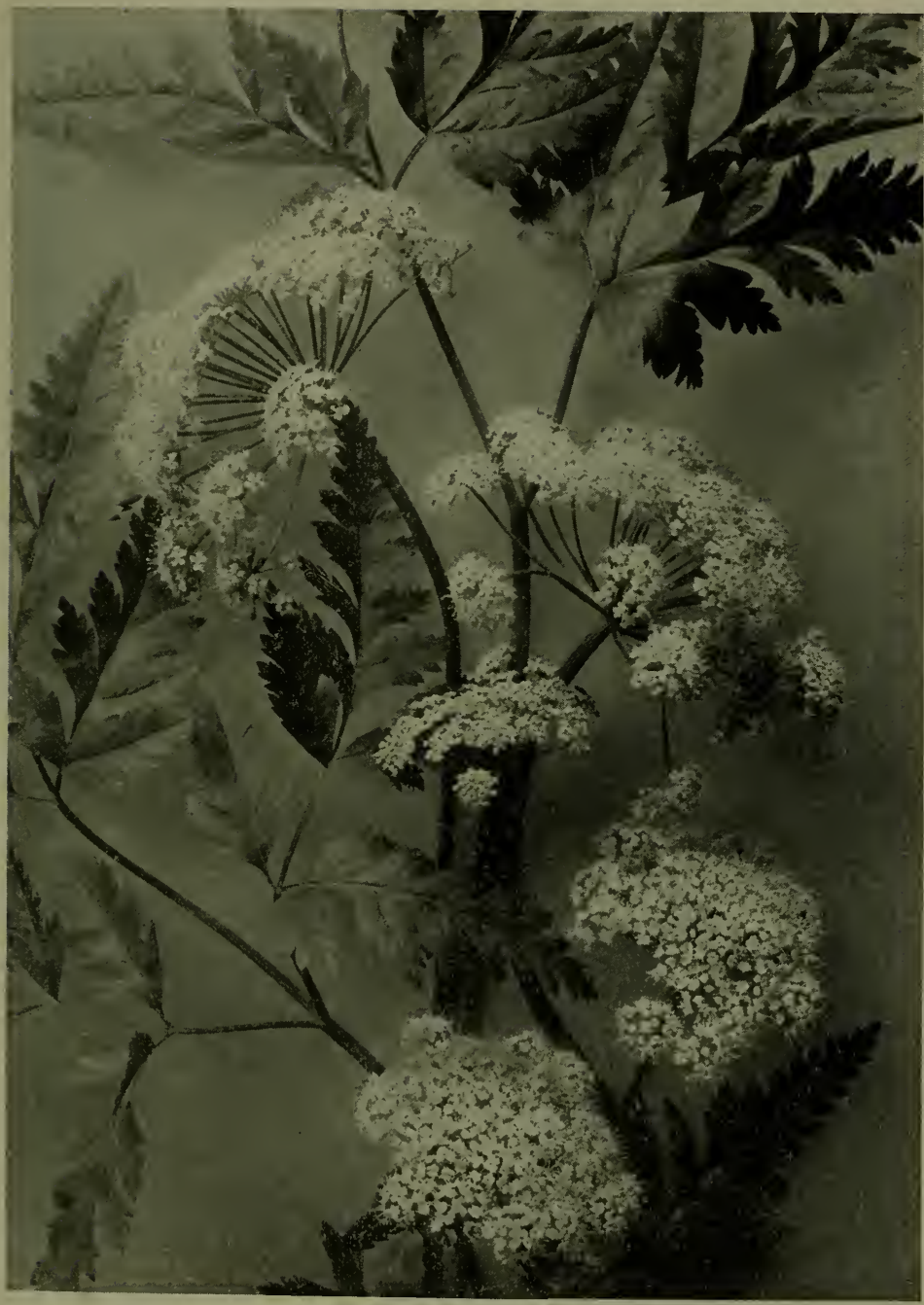

Fern-Leaved Lovage

(Ligusticum apiifolium) 
taller plant with more spreading umbels. Both of these Sweet Cicelys grow in the coniferous forests.

\section{FERN-LEAVED LOVAGE \\ Ligusticum apiifolium. Parsley Family}

Roots large, aromatic. Stems: thick. Leaves: radical, ternate, or biternate, then once or twice pinnate, the segments ovate, laciniately pinnatifid. Flowers: in umbels of numerous rays, with involucre of linear bracts; calyx-lobes obsolete.

A beautiful plant, having fine white flower-heads and decorative fern-like foliage.

Ligusticum Grayi, or Gray's Lovage, has leaves which are nearly all radical, and umbels of numerous rays with involucels of several narrow elongated bractlets. The fruit is oblong, with short conical stylopodia, and narrow prominent almost winged ribs.

\section{LARGE-SEEDED PARSLEY \\ Lomatium macrocarpum. Parsley Family}

Stems: nearly stemless. Leaves: compound, leaflets pinnately incised, on rather short petioles. Flowers: in a somewhat unequally three-to-ten-rayed umbel. Fruit: flattened dorsally, oblong, laterally winged.

A hairy Parsley much branched at the base from a thick elongated root. The leaves are compound, and the short stalks of the leaflets are purplish at the base. The white flowers grow in flat umbels.

\section{COW PARSNIP}

Heracleum lanatum. Parsley Family

Stems: very stout, tomentose-pubescent, rigid. Leaves: petioled, ternately divided, the segments broadly ovate, cordate, stalked, lobed and sharply serrate; petioles much inflated. Flowers: umbels manyrayed. 
PLATE XXXVI

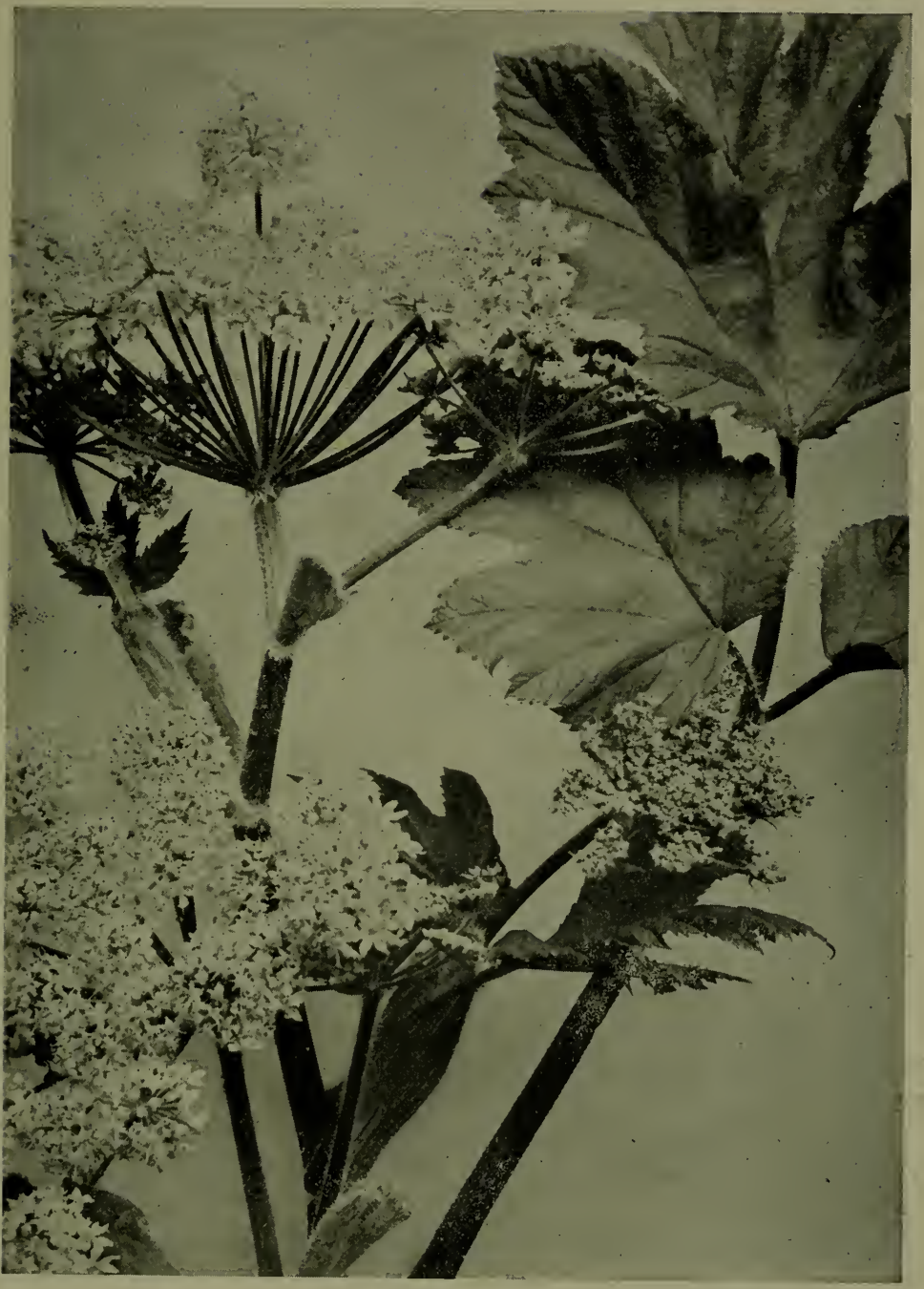

Cow PARSNip

(Heraclcum lanatum) 
Heraclcum, from the Greek name of Hercules, is an excellent designation for this huge Cow Parsnip, which among plants is certainly a veritable hero for strength and size, frequently growing to a height of eight feet. Its huge leaves and great clusters of white flowers, often measuring a foot across, are very showy, and once seen will always be remembered. The plant has an extremely nasty smell.

\section{BUNCHBERRY}

Cornus canadcnsis. Dogwood Family

Stems: erect. Leaves: verticillate at the summit of the stem, sessile, oval, pinnately veined, acute at each end, entire; bracts involucral, white. Flowers: greenish, capitate. Fruit: red, globose.

A slender tough stem bearing a circle of four or five oval, pointed leaves at its summit, out of the midst of which grows a cluster of inconspicuous tiny green flowers, surrounded by four beautiful white bracts, - such is the Bunch.berry, or Pigeonberry, which we find everywhere in the forests. It will surprise many travellers to learn that the lovely white leaves are not the petals, but only the bracts encircling the wee green flowers in the centre.

When these white bracts have fallen off, each flower-head derelops into a bunch of small scarlet berries, from which the species derives its common name.

Cormus stolonifera, or Red-osier Dogwood, is a handsome shrub, with bright red stems and numerous flat-topped clusters of pretty little greenish-white flowers, which have a very fragrant odour. The Western Indians call it Kinmikinic, and dry and use the inner bark in place of tobacco; while the half-breeds of the plains call it Harouge, signifying " a red switch." The fruit is a cluster of round dark blue berries. 


\section{PLATE XXXVII}

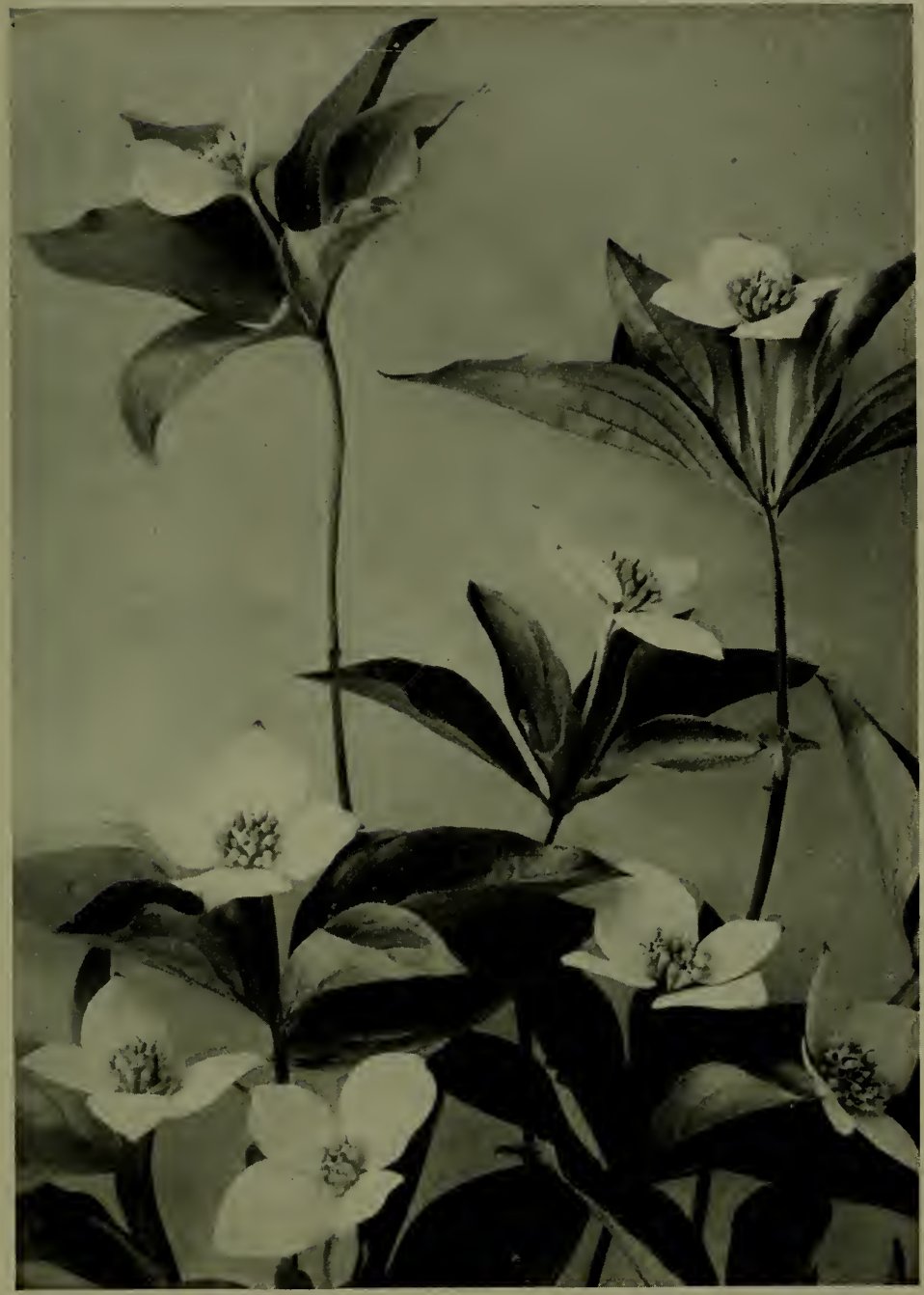

BUNCHBERRY

(Cornus canadensis) 


\section{ONE-FLOWERED WINTERGREEN}

Moneses uniflora. Heath Family

Stems: bearing three whorls of leaves at the base, continued above into a bracted scape. Leaves: orbicular, petioled, serrulate. Flowers: solitary, drooping; petals five, widely spreading, sessile; style straight; stigma peltate, large, conspicuous, with five narrow lobes.

Asa Gray has called this fragrant flower a "single delight," and certainly it is a joy to the traveller to find its solitary drooping blossoms bent close down upon the soft green carpet of the July woods. In the deep shade of the conifers beds of these exquisite waxen Wintergreens grow in profusion, each flower hanging its head and resembling a shining star. Turn its face upwards, however, and you will find its white petals have ten yellow-tipped stamens placed at their base, and that the style, which is very large and long, projecting from a conspicuous round green ovary, is crowned by a five-lobed stigma. The leaves are set in three circles on the stem, close to the ground, and are dark green, smooth-surfaced, and have serrated margins.

The One-flowered Wintergreen is a dweller in the darkest corners of the woods, where

"That delicate forest flower,

With scented breath, and look so like a smile, Seems, as it issues from the shapeless mould, An emanation from the indwelling life."

\section{GREEN-FLOWERED WINTERGREEN}

Pyrola chlorantha. Heath Family

Stems: three-to-ten flowered. Leaves: small, orbicular, coriaceous, not shining. Flowers: nodding; calyx-lobes short, ovate, acute; petals very obtuse; stamens declined; anthers distinctly contracted below the openings, with beaked tips; style declined, and curved upwards tọwards the apex, longer than the petals. 
This Lily-of-the-Valley-like plant is found in the dry woods among the moss, and always in the shade. On a tall, slender, single-bracted stalk grow numerous little nodding greenish-white bells, five-lobed, with yellow-brown stamens and a long, protruding, green style that is curved upwards at the apex and tipped by a large five-parted stigma. The leaves, round and small, grow in a cluster at the base of the plant, which springs from running roots. It has a slight sweet odour, and, in common with all the Pyrolas, is an evergreen.

Pyrola sccunda, or One-sided Wintergreen, has erect stems when young, but as the days pass and the little buds open, the weight of the secund raceme bends it over until it droops gracefully downwards. The flowers, which all grow on one side of the stem, are greenish-white in hue, and the long style protrudes far beyond the petals. The leaves grow at the base of the plant and are oval, their margins being serrated; they extend a short way up the stem, which is frequently bracted above.

Pyrola minor, or Small Wintergreen, is a smaller, more delicate species found principally near running water, and which has whiter bells than either of the two preceding forms. It may always be distinguished from other Pyrolas, even in bud, by the fact that it has a short style, which does not protrude beyond the petals of the globular blossoms. A slight fragrant scent emanates from its waxen bells. The leaves are oval with small rounded teeth and the flowers are nodding.

\section{STRIPED ALLOTROPA}

\section{Allotropa iirgata. Heath Family}

Stems: several from a deep-seated perennial routstock. Leaves: none, bracts scaly. Flowers: corolla none, calyx of five rounded sepals, 


\section{I76 White to Green and Brown Flowers}

erosely dentate. Fruit: capsule globose, seeds minute, scobiliform, the loose coat produccd at both ends.

There is only one known species of this curious parasitic plant, which is deep cream-coloured with red stripes. The numerous tiny flowers grow in a wand-shaped spike, and the ovate, scaly bracts are closely set at the base of the thick stems, becoming fewer above, and gradually passing into the narrow bracts of the many-flowered spike. The little pedicels are erect or spreading, and two-bracted, while the several stems grow from six to twelve inches high from a deep-seated, perennial rootstock.

\section{INDIAN PIPE}

Monotropa uniflora. Heath Family

Stems: smooth, fleshy, scaly. Leaves: none. Flowers: oblong, bellshaped, nodding, two to four sepals, four to five scale-like petals. Fruit: capsule erect, many seeded.

This waxy, cold and clammy plant is white throughout stalks, scales, and flowers - only the eight or ten yellowish stamens giving a faint touch of colour to its ghost-like appearance. Very rarely the Indian Pipe is rose-colour, and always it turns blackish when dying. Of all ghoulish parasites the Monotropas are among the worst, their matted, brittle, fibrous roots preying on the juices of other plants, or on dead and decaying matter. The single, bell-shaped flower hangs its head at the top of each scaly stalk, but when the numerous seeds begin to form it raises its head erect.

Monotropa Hypopity's, or Pinesap, has white, tawny or rose-coloured flowers that are very fragrant, and oblongbell-shaped, borne in a one-sided, terminal, drooping raceme, and, like the Indian Pipe, becoming erect at maturity. The scaly-bracted scapes rise in clusters from a mass of fleshy, 
PLATE XXXVIII

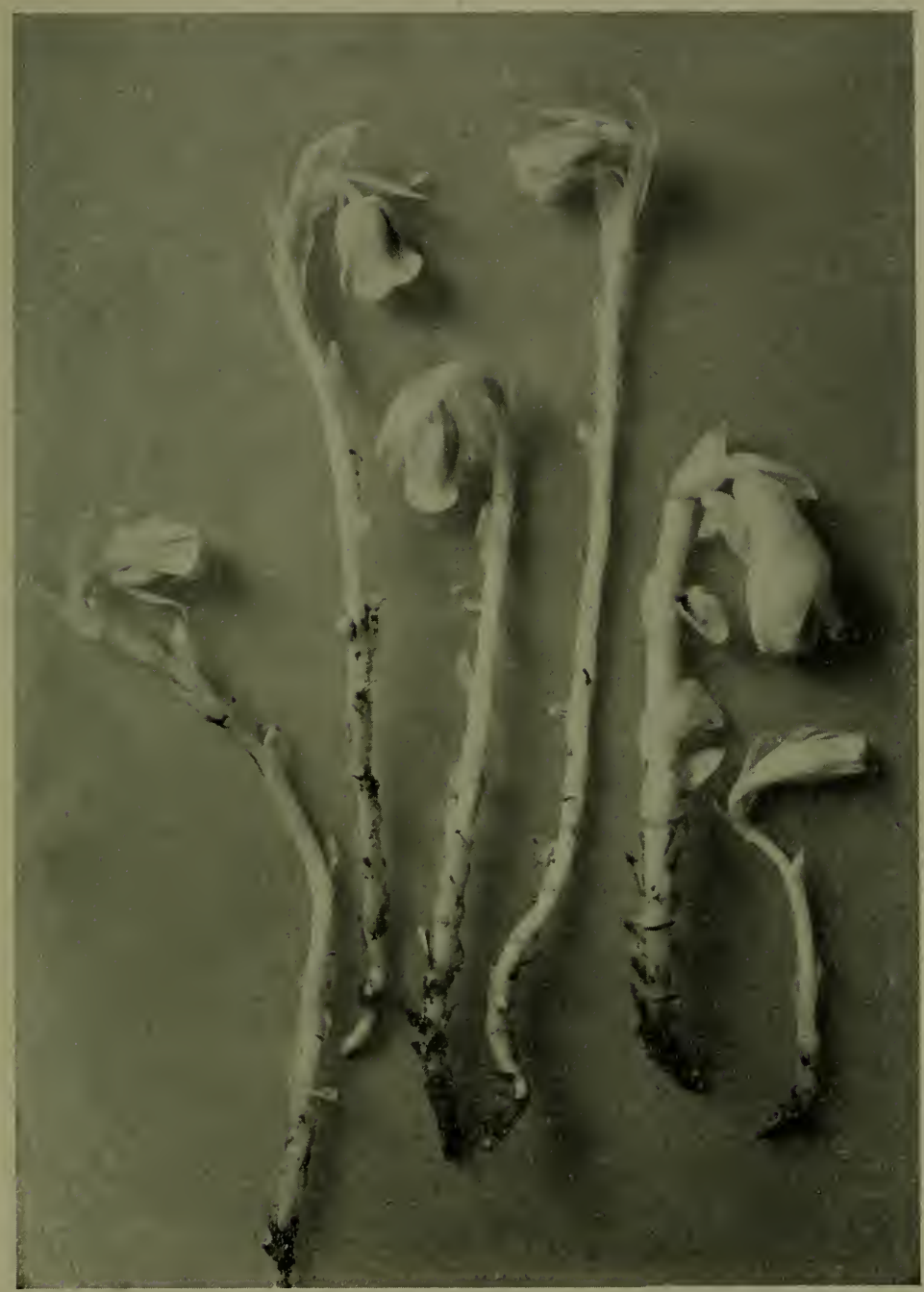

Indian Pipe

(Monotropa uniflora) 
fibrous roots, the bracts very densely imbricated at the base of the peduncles, and, together with the preceding species, the Pinesap is branded as a parasite by the loss of all leaves and chlorophyll.

\section{PINE DROPS}

\section{Pterospora Andromedea. Heath Family}

Stems: scape bracted, grooved, densely covered with viscid hairs. Leaves: none, bracts lanceolate or linear, very numerous, crowded at the base. Flowers: numerous, racemose. Fruit: capsule globoseovoid, tapering, with a reticulated broad wing.

The roots of this parasitic plant are extremely astringent and form a thick fibrous mass, often two feet in diameter. The scape is brownish or purplish, grooved, and thickly covered with sticky hairs. It stands from six inches to two feet high, and the white, bell-shaped, nodding flowers grow in a long, terminal, bracted raceme. The narrow bracts are very crowded at the base of the scapes, and the whole plant is clammy and glutinous.

\section{NEWBERRYA}

Nerwberrya congesta. Heath Family

Stems: scapes four to eight inches high. Leaves: none, scales crowded or loosely imbricated, obtuse. Flowers: greenish, brownish, reddish, in a terminal cluster. Fruit: ovary ovate, contracted at the apex into a long style, stigma depressed-capitate, umbilicate.

An erect, low, fleshy, parasitic plant, with greenish, brownish or reddish flowers growing in a terminal raceme. The calyx is incomplete, of two bract-like, entire sepals, and the corolla is tubular-urceolate, four to five lobed and persistent. The whole plant is brownish and stands four to eight inches high. The scales are thin, with slightly erose 


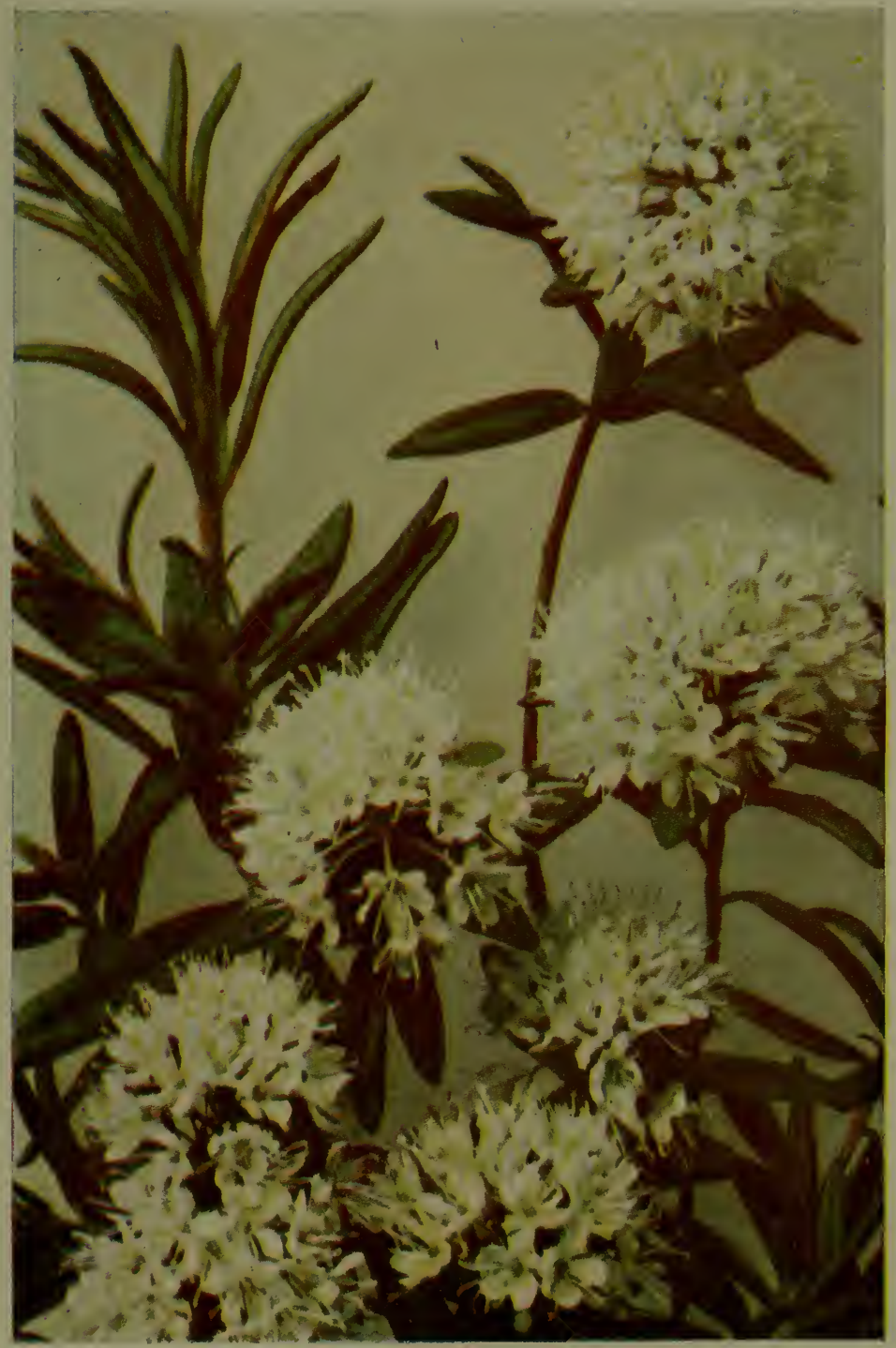

WOOLLY LABRADOR TE.t

(Ledum grocnlandicum) 

margins, the upper ones forming the bracts of the denselycrowded, compact flower-clusters.

\section{WOOLLY LABRADOR TEA}

Lcdum gronlandicum. Heath Family

Stems: erect or ascending, the bractlets rusty-tomentose. Leaves: oblong, obtuse, green and slightly rugose above, densely tomentose beneath, the wool soon ferruginous, and the margins strongly revolute. Flowers: umbellate or corymbose, numerous, terminal; petals five, spreading; pedicels brown-canescent, recurved in fruit.

This lovely flowering shrub thrives chiefly on low-lying flats and in wet marshy places, where its large terminal clusters of snow-white blossoms grow abundantly from sticky scaly buds on the low bushes. The foliage of the IVoolly Labrador Tea is strictly characteristic, for the leaves are long-shaped, with revolute margins, green and slightly wrinkled on the top and densely woolly underneath, the wool in the developed foliage being the colour of iron rust. This thick woolly growth is probably designed for the express purpose of protecting the pores of the leaves from becoming clogged by the moist vapours that must necessarily rise round about them, owing to the extremely wet ground in which the shrubs flourish. Plants that grow in very damp localities are specially dependent upon the free perspiration of their leaves to throw off the vast quantities of moisture they absorb through their roots and stems; consequently such marsh shrubs as the Labrador Teas are forced to adopt a regular system in order to prevent the pores of their leaves from becoming so congested with moisture from outside that they cannot perform their legitimate function of throwing off the moisture from within. The small branches are also covered with red, rusty, wool-like hairs. 
The flower-clusters are very beautiful, each individual blossom consisting of five pure white petals, with a large green ovary set in the centre; the style and numerous long stamens are very conspicuous. Both the flowers and leaves have a strong aromatic fragrance.

Ledum glandulosum, or Smooth-leaved Labrador Tea, has also long-shaped, thick, leathery leaves of a brownishgreen hue, but they are not woolly underneath, being quite smooth on both sides, though slightly white and resinous below. The flower-clusters closely resemble those of $L$. gronlandicum.

The name Labrador Tea is derived from the fact that many old settlers, and also campers and lumbermen in the backwoods, formerly used in place of tea a decoction brewed from the aromatic leaves of this shrub.

\section{MOUNTAIN RHODODENDRON}

\section{Rhododendron albiflorum. Heath Family}

Leaves: membranaceous, oblong, obscurely undulate. Flowers: from separate one-to-three flowered, lateral, scaly, cone-like buds below the leaves; calyx five-parted, the divisions more or less foliaceous; corolla five-lobed; filaments bearded at the base, open-campanulate; stamens ten; style peltate, five-lobed.

This is one of the most beatuful flowering shrulss found growing on the highest mountains.

"Oh, the windings up and down

That the dizzy pathway took!

Now along the craggy bed

Of a sun-dried mountain brook;

Now along a ledge that led

By a chasm's crumbling brink,

Dropping deep and sheer away

Through the golden Syrian day

To the dreamy blur of pink 
PLATE XXXIX

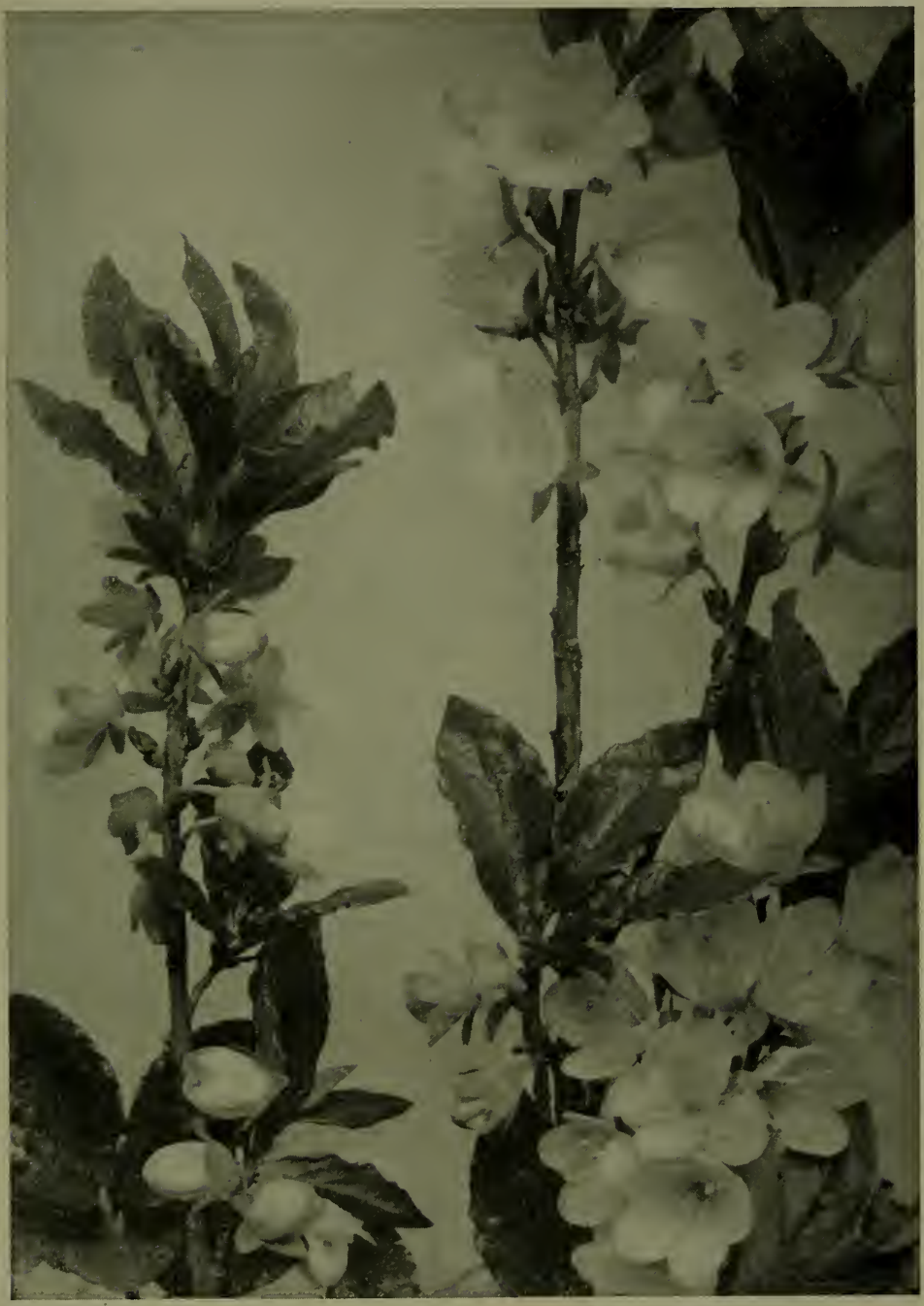

Mountain Rhododendron

(Rhododendron albiflorum) 


\section{White to Green and Brown Flowers}

That the oleanders made,-

Here in sun, and there in shade.

$\mathrm{Up}$, and up, and up we went,

While, a spacious azure tent,

Arabesqued with morn, the sky

Hung above us radiantly."

Had the poet who penned these lovely lines referred to

... the creamy blur of white

That the rhododendrons made,

his verses would as fitly have described the finding of the exquisite waxen bells of the Mountain Rhododendron as that of

"The dreamy blur of pink

That the oleanders made,"

for it is on the most inaccessible ledges, and close to the great slopes of eternal snow, that the oblong glossy green leaves of this alpine shrub gleam brightly in the sunshine of the July days, and the slim, stiff, brown stems bear aloft clustering circles of pure white flowers, holding within their chalice-cups the ten pale yellow stamens and the style. The edges of the foliage are slightly wavy, the calyx is fiveparted, each division resembling a small leaf, and the corolla is bell-shaped and cut into five rounded lobes. The buds are scaly and cone-like.

\section{WHITE MOUNTAIN HEATHER}

Bryanthus glanduliflorus. Heath Family

Stems: rigid, fastigiately branched. Leaves: numerous, crowded, but somewhat spreading, linear-oblong, obtuse, narrowed at the base to a short petiole. Flowers: corolla short-lobed, glabrous.

The flowers of the White Mountain Heather are like little fat cream-coloured bulbs, with a tiny opening that is lobed. 
Its leaves are longer and more spreading than those of the Heath, near which it usually grows.

\section{WHITE HEATH}

Cassiope Mertensiana. Heath Family

Stems: rather stout, rigid, ascending with fastigiate branches, lowgrowing. Leaves: glabrous, carinate, and not furrowed on the back, imbricated in four ranks; corolla five-lobed.

The beautiful white mountain Heath grows abundantly at high altitudes and is much prized by travellers. Its branches appear four-sided by reason of the manner in which the tiny leaves grow on them, and from these branches slender stalks are sent forth bearing at their tips waxen nodding bells, each composed of a five-lobed corolla with a small green calyx.

"Meek dwellers mid yon terror-stricken cliffs, With brows so pure, and incense-breathing lips, Whence are ye? Did some white-winged messenger, On Mercy's missions, trust your timid germ.

To the cold cradle of eternal snows;

Or, breathing on the callous icicles, Bid them with tear-drops nurse ye?"

Cassiope tetragona, or Four-angled Heath, is a very rare plant. It has ascending branches, and the leaves which are closely appressed and channeled on the back are imbricated in four rows which makes the branches appear four-sided. The flowers greatly resemble those of the preceding species.

\section{RED-BERRIED GAULTHERIA}

Gaultheria ovatifolia. Heath Family

Stems: depressed, trailing, with ascending branches. Leaves: broadly ovate, serrulate. Flowers: on short solitary pedicels in the axils of the leaves. Fruit: a berry. 


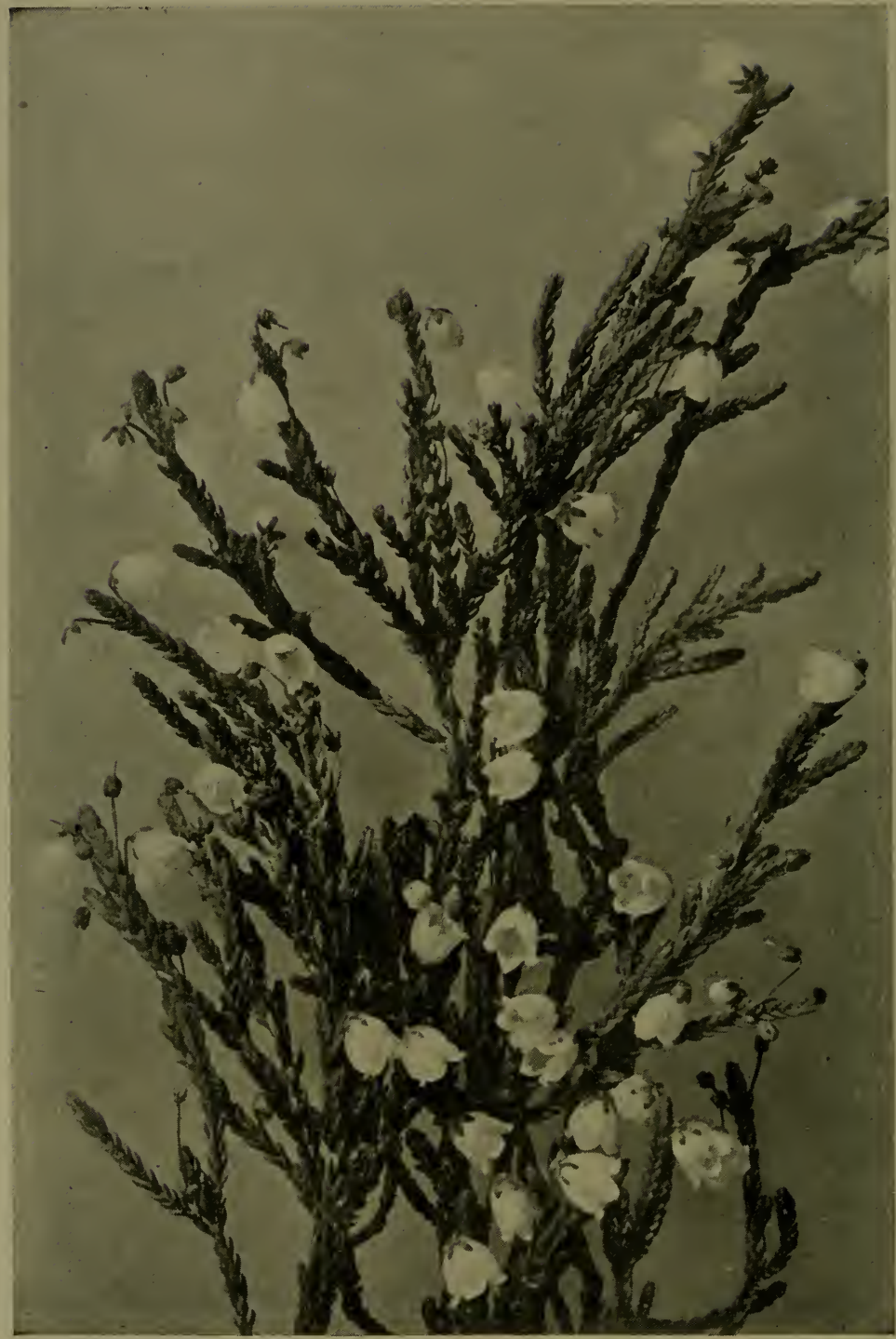

White Heath

(Cassiope Mertensiana)

I84 
The bright scarlet berries of this plant, formed of the calyx, are extremely attractive and aromatic. The eggshaped leaves are evergreen, dark and shining above and a lighter colour beneath, and have blunt-toothed margins. The white or pale pink flowers are campanulate with recurved lobes.

Gaultheria humifusa, or Creeping Gaultheria, is a tufted species with flowering branches one to five inches long and small oval leaves. The pinkish-white flowers are depressedcampanulate, little exceeding the calyx in length, and the fruit resembles that of the preceding species. These plants are named after Hugues Gaultier, a naturalist and courtphysician at Quebec in the middle of the I8th century.

\section{SWEET ANDROSACE}

\section{Androsace Chamajasme. Primrose Family}

Stems: slender. Leaves: in more or less open rosulate tufts, onenerved, ovate. Flowers: in capitate umbels.

The sweet smell of these delicate little clustered blossoms, that grow from one to three inches above the soil and fill the air with fragrance, is most attractive. Their primrose-like petals, of creamy or pinkish hue, look up with yellow eyes to greet each passer-by, while rosulate tufts of tiny narrow leaves are set about the slender stems.

Androsace septentrionalis, or Alpine Androsace, is a very different species from the foregoing one, having muchbranched thread-like stems bearing numerous tiny white flowers. The leaves are lance-shaped and rosulate.

Androsace diffusa, or Spreading Androsace, is more or less hairy and has narrow rosulate leaves which are sparingly toothed. The scapes are erect, spreading and oftein diffusely branched, and the pinkish-white flowers have a 
corolla which equals the tips of the calyx segments in length.

\section{STAR-FLOWER \\ Trientalis arctica. Primrose Family}

Rootstock creeping, sending up many stem-like branches, which are naked below, the leaves all in a verticil of five to ten at the summit. Leaves: membranous, lanceolate, acuminate at both ends, sessile. Flowers: solitary or few; calyx usually of seven sepals; corolla wheelshaped, of seven petal-like segments.

The pretty blossoms of this Star-flower are generally white, though sometimes tinged with mauvish-pink, and so gracefully are they poised on slender stalks above a whorl of pointed leaves that every puff of wind blows them gently to and fro. The number seven recurs with marked frequency in this particular plant, - the calyx is seven-parted, the corolla segments are seven, and the stamens seven, while the leaves of the whorl also are usually seven in number, some being large and some small.

Bryant writes of the alpine meadows,

"Where star-flowers strew the rivulet's side,"

but as a matter of fact it is generally in the shady woods, near the foot of some large forest tree, that these dainty little flowers are found.

\section{MARSH BUCKBEAN}

\section{Menyanthes trifoliata. Gentian Family}

Rootstock: thick, scaly, marked by the scars of bases of former petioles. Leaves: trifoliate, leaflets oblong, entire, obtuse at the apex, narrowed to the sessile base. Flowers: in a raceme borne on a long, scape-like, naked peduncle; calyx short; corolla funnel-form, five-cleft, its lobes bearded within.

This is a perennial swamp herb whose lovely white flowers and triple leaves are the glory of many a secluded moun- 
tain marsh. The face of the five white or purplish-pink divisions of the corolla are covered with soft hairs, which give the flowers a dainty feathery appearance, and inside the tube are placed the five stamens, while the style is long and projects beyond them.

\section{MIST MAIDENS}

Romanzoffia sitchensis. Water-leaf Family

Stems: slender, scape-like, ascending or spreading. Leaves: roundreniform, three-to-seven lobed on slender petioles. Flowers: in a loose terminal raceme; corolla funnel-form, the broad lobes rounded.

One of the most exquisite fragrant alpine plants, that grows

"Where the sunlight fills the hours,
Dissolves the crust, displays the flowers."

At high altitudes, when the warmth of July has melted the snow and set the flowers free, you will find the creamy blossoms of these Mist Maidens in many a nook amongst the forbidding rocks, their corollas shimmering like pearls in the green setting of their round scalloped leaves. The texture of these flowers is simply marvellous, for they have a bloom upon them so beautiful that it resembles nothing less than richest white velvet, while in their centres a few pale yellow stamens give to each blossom a heart of gold.

Mist Maidens are seldom found below an altitude of 6000 feet, and where the cliffs rise bleak and barren, where the ways are ice bound and the rocks are bare, there it is a joy to find this lovely plant snugly ensconced in some tiny cleft that is watered by the melting snows. Only those who have toiled and climbed in search of it can know the full delight of its discovery. 


\section{PLATE XLI}

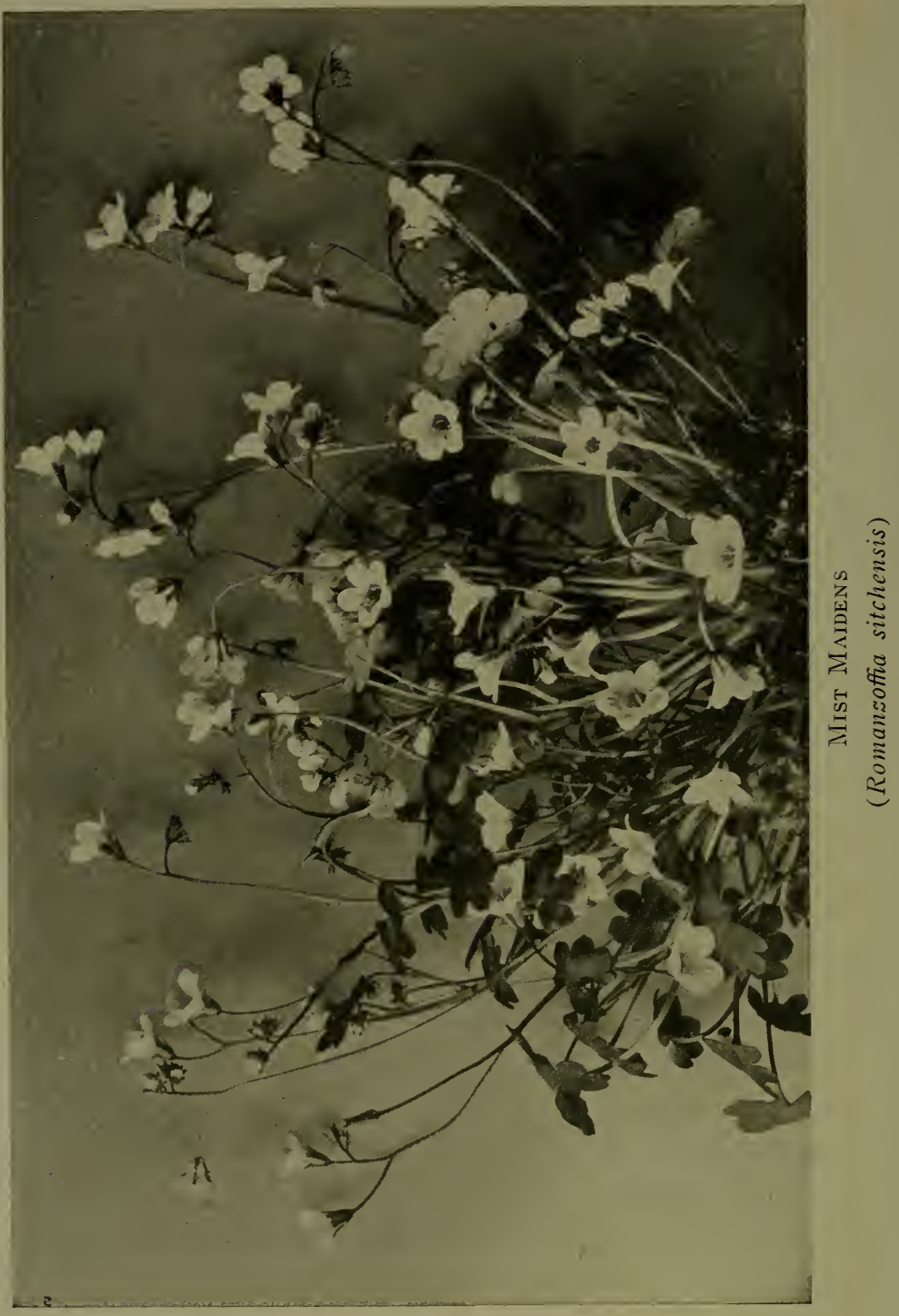




\section{WHITE LOUSEWORT}

Pedicularis racemosa. Figwort Family

Stems: glabrous, leafy to the top. Leaves: all cauline, lanceolate, undivided, finely serrulate. Flowers: few, in short leafy racemes; calyx oblique, deeper cleft before than behind, the lobes abruptly acuminate; galea produced into an incurved beak, nearly as long as the broad lower lip, hamate-deflexed.

The dull white or very pale yellow beaked flowers of the White Lousewort are set in a close cluster at the top of the stalks, and are embedded amongst small deeply-fringed leaves.

The repellent common name of this plant is derived directly from the Latin one, which was bestowed upon it because once upon a time farmers believed that when their flocks fed upon these flowers the sheep were liable to be attacked by certain tiny lice, called pediculus.

Pedicularis contorta, or Contorted Lousewort, is very like the White Lousewort but has cream-coloured flowers set singly all the way up on the slender stalks. Its foliage is fern-like and often tinged with reddish-brown; long leaves grow out from the base, and small ones are incerspersed with the numerous blossoms on the stems.

The Contorted Lousewort grows at very high altitudes, being usually found at 7000 feet.

\section{COMMON PLANTAIN}

Plantago major. Plantain Family

Rootstock short, thick, erect. Leaves: spreading, ovate, entire; spike dense, obtuse at apex. Flowers: perfect, proterogynous; sepals broadly ovate, scarious on the margins. Fruit: pyxis seeded, circumsessile near the middle. 


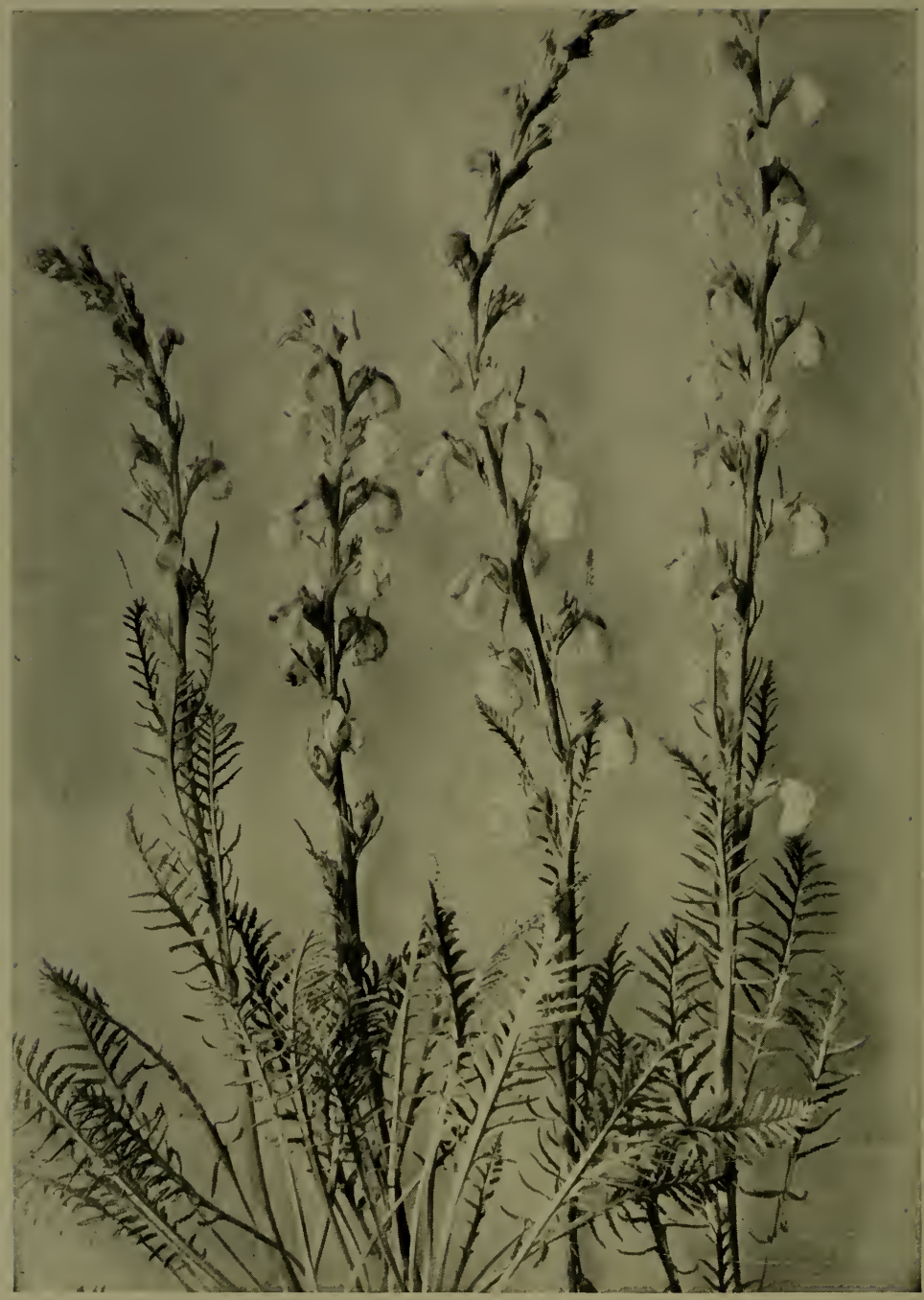

Contorted LOUSEWORT (Pedicularis contorta) 
The Common Plantain is so familiar to travellers that it calls for no special description. It has greenish flowerspikes and reddish seeds.

Plantago major z'ar. asiatica, or Asiatic Plantain, has oval several-ribbed leaves, the base abruptly contracted into a petiole, and longer less dense spikes of greenish flowers than the preceding species. Kalm says that in the United States Plantains were formerly called "Englishman's Foot," because it was believed that wherever a Britisher went these plants always followed in his steps. This is an introduced plant.

\section{NORTHERN BEDSTRAW}

Galium boreale. Madder Family

Stems: smooth, branched, leafy. Leaves: in fours, linear, acute. Flowers: in terminal panicles, dense, many-flowered in small compact cymes. Fruit: hispid.

The Northern Bedstraw may be distinguished by the fact that its tiny narrow leaves grow in circles of four round the stems. It is a plant bearing many small white flowers in clusters, and the seeds are twin burs, covered with numerous hooked bristles, by means of which they cling to the clothing of the passer-by and the fur of animals.

Sir John Franklin in his book The Polar Seas describes this plant as being used by the Indians as a vegetable dye. They call it Sawoyan, and after boiling the roots they mix the liquid with the juice of strawberries and cranberries, and thus obtain a beautiful scarlet dye.

Galium triflorum, or Sweet-scented Bedstraw, always grows in threes, or on three-branched stems, as might be inferred from the name triflorum. The leaves are a trifle broader than those of $G$ : boreale, but the flowers of both 
have a four-lobed white corolla. At all times, but especially when dried, this plant has a sweet odour resembling that of vanilla. Its seeds are two-lobed and are covered with tiny hooked hairs, which have earned for it the descriptive name of "Cleaver," for verily its burs cleave fast to anything with which they come in contact.

Galium trifidum, or Small Bedstraw, has slender weak four-angled stems, very freely intertangled, and forms dense mats on the ground. The narrow spatulate primary leaves are usually in fours and the pale flowers are solitary on long stalks and grow in pairs at the nodes. It is a wetloving plant.

\section{SNOWBERRY}

Symphoricarpus raccmosus var. pauciflorus. Honeysuckle Family

Leaves: opposite, broadly oval, entire, softly pubescent. Flowers: solitary in the upper axils, and two or three in the terminal spike; corolla campanulate, five-lobed, bearded within; stamens and style included. Fruit: a white berry.

When in flower this low spreading shrub bears its small white or pinkish bells in tiny clusters at the ends of the numerous upright branches, and also singly in the upper axils of the leaves. When in fruit the pretty, white, waxen berries render the Symphoricarpus both conspicuous and attractive. These berries are oval in the early stages of development, when with their snowy weight they bend down the flexible branches, and become rounded at maturity. They contain two brown bony seeds, embedded in the granular cellular pulp. The dark green leaves are broadly oval in shape and have smooth margins.

The Snowberry is frequently cultivated in gardens as an ornamental shrub. 


\section{ARROW-WOOD}

\section{Viburnum pauciflorum. Honeysuckle Family}

Leaves: broadly oval, obovate, with three rather shallow lobes above the middle, coarsely and unequally dentate, glabrous above, more or less pubescent beneath. Flowers: white, in compound cymes, all perfect and small; corolla campanulate, five-lobed. Fruit: drupes globose, bright red, acid.

A straggling shrub growing from two to six feet high and bearing many small clusters of tiny white and pinkish flowers, whose bell-shaped corollas are divided into five lobes above the middle and are pointed and coarsely toothed.

\section{RED-BERRIED ELDER}

Sambucus racemosa. Honeysuckle Family

Stems: woody. Leaves: pinnately compound ; leaflets lanceolate, acuminate at the apex, sharply serrate. Flowers: in thyrsoid cymes, white to yellowish. Fruit: small, scarlet.

This shrub, which grows from ten to thirty feet high and has spreading branches and ample foliage, is widely distributed over the continent. In fields and forests, by the roadsides and in neglected gardens, you will find it springing up and thriving with undaunted hardihood amid the most barren surroundings. It also grows at many elevations, being seen in quantities at the sea level and also flourishing abundantly at an altitude of 6000 and 7000 feet. The leaves are divided into from five to seven leaflets, and the creamy fragrant flowers grow in elongated clusters at the ends of the branches. The fruit is a bright scarlet drupe, with a pungent acid flavour.

Sambucus melanocarpa, or Black-berried Elder, does not grow quite so luxuriantly as the preceding species, yet its sweet-scented misty clusters adorn many a patch and thicket. 
The fruit, as the name denotes, is a rich blue-black colour and very juicy. It is from this shrub that Elderberry wine is made.

\section{NORTHERN HELIOTROPE}

\section{Valeriana septentrionalis. Valerian Family}

Stems: erect from creeping rootstocks. Leaves: basal, oblong, entire; stem-leaves petioled, three-to-seven foliolate, the divisions entire. Flowers: cymose, paniculate, more or less dimorphous; corolla funnel-form, five-lobed.

So sweet is the smell of the Northern Heliotrope that few can mistake it. The flowers are very handsome, white tinged with mauve or pink, and grow in big clusters on the top of juicy stalks from eight to eighteen inches high, and in two small axillary clusters a few inches below the terminal cyme. The foliage of this plant is handsome, the leaves being strongly veined, glossy, and of a beautiful bright green colour.

The margins of these leaves are entire,- that is, not cut or toothed,- - and herein lies the difference between this plant and Valeriana sitchensis, or Wild Heliotrope, which can only be readily distinguished from it by the fact that the latter's leaves are coarsely dentate, the flowers of both species being almost identical. A very noticeable feature of the Valerians is their extremely long stamens, and their roots have a very strong and disagreeable odour, which is a curious contrast to the delicious fragrance of the flowers.

\section{WHITE ASTER}

\section{Aster commutatus. Composite Family}

Stems: bushy, branched. Leaves: rigid, linear, entire, obtuse, sessile, uppermost passing into involucral bracts. Flowers: in densely crowded heads. 


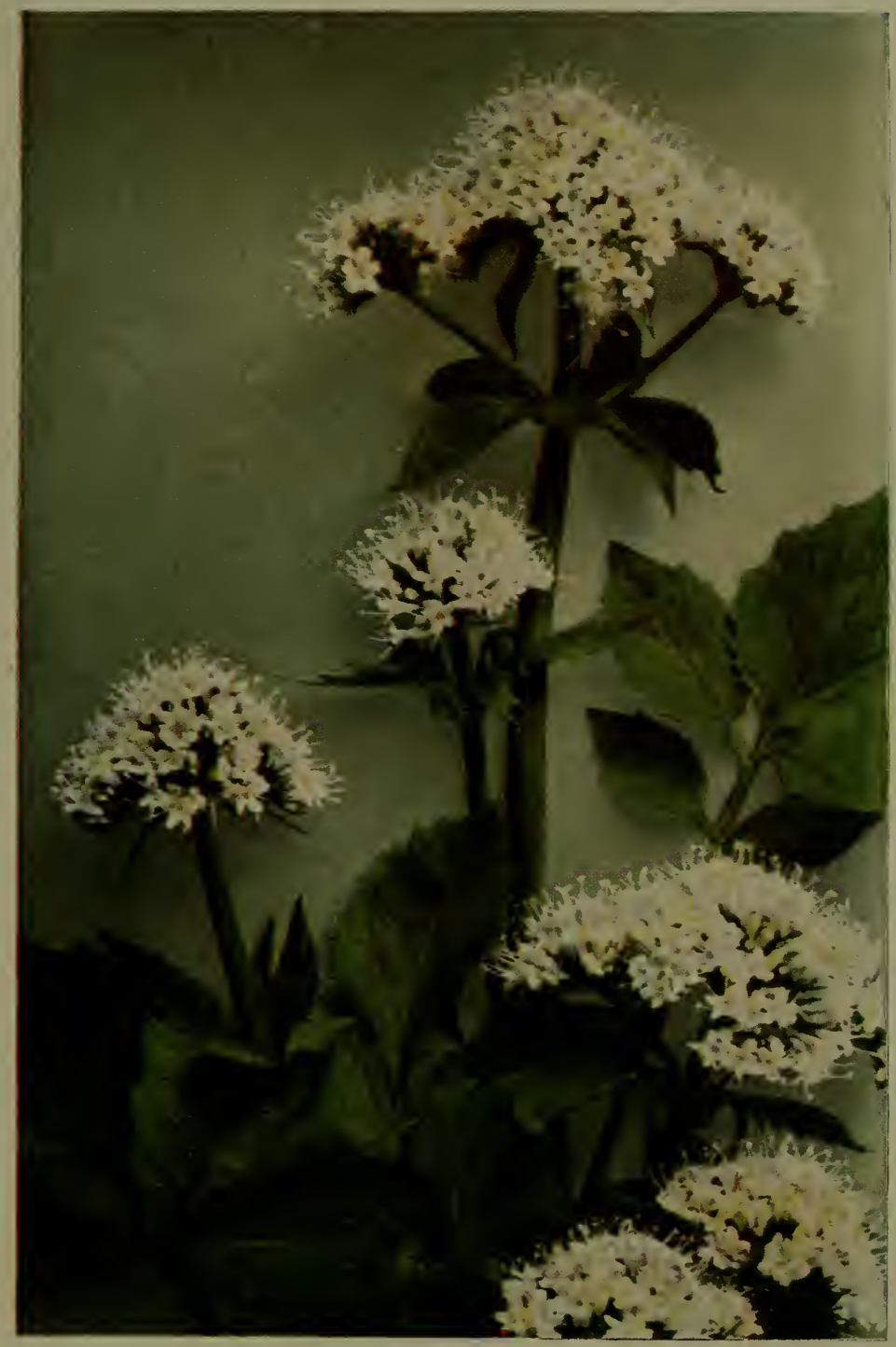

IVILd Heliotrope

(I'aleriana sitchensis) 

These charming little Asters, with their white rays and yellow centres, are quite unmistakable, and though each individual flower is small, yet they grow in such large denselyflowered wands that they present a very handsome appearance. The stiff narrow leaves grow all the way up the stalks among the blossoms. The flower is usually found in very dry sandy places.

Aster alpimus, or Alpine Aster, is another species very abundant in the mountains. It grows at great altitudes and has fluffy whitish leaves and white or pale pink flowers.

\section{FERN-LEAVED FLEABANE \\ Erigeron compositus. Composite Family}

Stems: short, densely leafy. Leaves: fan-shaped in outline, parted into linear spatulate lobes on long petioles; herbage hirsute and rather viscidulous. Flowers: rays forty to sixty, white; disk-flowers yellow.

This Fleabane is very like a large common daisy, for it has many white rays and a big yellow centre. Most of its leaves grow out from the base, and are much cut and quite fern-like. It is found at an altitude of 7000 feet, and especially along the edge of glacial streams, though it grows also on the lower alpine meadows.

The most conspicuous difference between Asters and Fleabanes is that the latter have very numerous narrow rays, while the rays of the former are slightly broader and much fewer in number.

Erigeron multifidus, or Daisy Fleabane, has numerous slender hairy stems and leaves crowded on the crowns of the caudex, twice-ternately parted into narrow lobes. The flowers are solitary at the ends of the nearly leafless stems; they are usually white, but occasionally violet.

Erigeron melanocephalus, or Black-ivoolly Fleabane, has 


\section{I96 White to Green and Brown Flowers}

stems covered with purplish-black hairs. The lower leaves are numerous elliptic and nearly smooth, while the stem leaves are very hairy. The involucre is thickly covered with purplish-black wool and the fifty to sixty rays are white or pinkish.

Erigeron caspitosus, or Tufted Fleabane, has very tufted white-haired stems growing from a deep root. The leaves are also white-hairy narrow and have even margins, the involucre is hemispheric, its bracts narrow pointed and white-hairy, and the forty to sixty rays are white or pinkish.

\section{WHITE EVERLASTING}

\section{Antennaria raccmosa. Composite Family}

Freely surculose by long, slender, sparsely-leafy stolons, lightly woolly. Stems: bearing numerous racemosely-disposed heads. Leaves: broadly oval, acute at each end, densely tomentose beneath, green and glabrous above; involucre campanulate; bracts green. Flowers: staminate and pistillate heads white-tipped.

Every traveller will recognize the Everlastings at a glance, with their dry, crackling little flowers and partially, if not entirely, silky whitish leaves; the only difficulty lies in deciding to what species any particular plant belongs.

The easiest way to distinguish the White Everlasting is by the loose separate fashion in which its flower-heads grow, just a few on each little stalk and none of them bunched together.

Antennaria Howellii, or Mouse-ear Everlasting, differs from the preceding species in having very closely clustered flower-heads and much more silky leaves. The leaves of both these plants are woolly and white underneath and smooth and green on the top. The fertile plants are taller than the sterile plants, and the little heads of fertile florets 
are set in green cups, their snow-white silky tufts gleaming in the sunshine, while the staminate florets have rounder, whiter scales.

Antemnaria parvifolia, or Mountain Everlasting, has leaves that are white and woolly on both sides, and its florets are perfectly round in shape.

Antemnaria lanata, or Arctic Everlasting, is a dwarf species growing close to perpetual snow, and is found at the great altitude of 8000 feet. It has very white and woolly stalks and many tiny leaves which are white and woolly also.

This plant somewhat resembles the Edelweiss of the Alps, and is the nearest approach to that famous flower to be found on this continent. The name Antenuaria refers to the long brown anthers, which resemble the antennæ of some insect.

Antennaria pulcherrima, or Tall Everlasting, is whitewoolly throughout. The leaves are narrow spatulate pointed and nerved, while the flower heads are numerous in a close capitate cluster, the outer bracts of the involucre being straw-coloured rounded and often notched at the apex, and the inner ones white.

Antennaria alpina, or Alpine Everlasting, has woolly stems, a number of spatulate tufted basal leaves which are silvery-woolly on both sides and a few small stem leaves. The flower heads grow in a terminal cluster and the bracts of the fertile ones are brownish-green, those of the sterile ones being lighter and broader.

Antennaria media, or Silky Everlasting, is a very silkywoolly plant with stems from one to six inches high. The radical leaves are obovate and the cauline ones narrow. The flower heads are few, the pistillate ones grow in a close 


\section{I98 White to Green and Brown Flowers}

cluster, while the staminate ones are panicled and have bracts with scarious white tips.

\section{PEARLY EVERLASTING}

Amaphalis margaritacea. Composite Family

Stems: floccose, woolly, corymbosely branched at the summit, leafy. Leaves: linear, lanceolate, green pubescent above, woolly below. Flowers: in numerous heads; involucre campanulate, its bracts ovate, obtuse, finely stricate:

This is the finest of all the Everlastings, and if picked and carefully kept in a vase, will remain fresh looking for months. Its flowers are large, slightly sweet scented, and pearly white, and are often used for funeral wreaths; as if to say:

"They are lore's best gift, Bring flowers - pale flowers."

\section{YARROW}

Achillea lanulosa. Composite Family

Stems: simple, or corymbosely branched above. Leaves: narrowly oblong, bipinnately dissected into numerous small linear divisions. Flowers: in numerous heads crowded in a fastigiate cyme.

A plant, or rather weed, so common that every child knows its large white and pinkish flower-heads and recognizes the disagreeable pungent odour of its lace-like leaves. It is often called "Milfoil" from the abundance of its fringed foliage.

This species may readily be distinguished by its densely woolly character, and the fact that none of its bracts are dark-margined.

The Yarrow must unquestionably be of ancient origin, for it derives its name Achillea from Achilles, who is sup- 
posed to have made an ointment from it wherewith to heal his wounded warriors after the siege of Troy.

Achillea borealis, or Dark-margined Yarrow, is not so tall or so woolly as the preceding species, the corymbs are smaller and the bracts are all dark-margined.

\section{OX-EYE DAISY}

Chrysanthemum Leucanthemum. Composite Family

Stems: glabrous, simple, the branches nearly erect. Leaves: obovate, oblong, coarsely dentate; stem-leaves sessile, partly clasping, linear, pinnately incised, the uppermost very small, nearly entire. Flowers: solitary, or few, on long peduncles; rays twenty to thirty. Not indigenous.

How many poets have sung the praise of the Daisy, from Robert Burns, who described the little English blossom that grows close to the turf as a

"Wee, modest, crimson-tipped flower,"

to Bliss Carman, the clever Canadian writer, who tells how

"Over the shoulders and slopes of the dune

I saw the white daisies go down to the sea-

A host in the sunshine, a snow-drift in June,

The people God sends us to set our hearts free,"

and in doing so describes the big wild Ox-eye Daisies which mantle the alpine meadows with their showy white petals and golden hearts.

This is an introduced plant.

\section{PASTURE WORMWOOD}

Artemisia frigida. Composite Family

Stems: simple or branching, silky-canescent and silvery all over, herbaceous from a suffrutescent base. Leaves: twice ternately or quinately divided into linear crowded lobes. Flowers: numerous racemosely disposed heads in an open panicle, globular. 
All the Wormwoods possess a very strong odour, by means of which they may be easily recognized. This species has tiny greenish-yellow flowers growing profusely on its leafy, silky stems, while the whole plant is silvery white and covered with softest down.

Artemisia discolor, or Green Wormwood, has green foliage and brownish-green florets, having the same pungent aromatic smell as the silvery species.

Artemisia biennis, or Biennial Wormwood, has also green foliage, and its numerous greenish florets grow in clusters in the axils, where the leaves join the main flower-stalk.

\section{PALM-LEAVED COLTSFOOT}

Petasites palmatus. Composite Family

Stems: scaly, stout. Leaves: orbicular in outline, deeply seven-toeleven cleft, green and glabrous above, densely white tomentose beneath. Flowers: in a fastigiate panicle.

The chief distinction between the different species of Coltsfoot lies in the shape of their respective leaves. Those of the Palm-leaf Coltsfoot are exactly like a large palm leaf, while its blossoms are white and very fragrant. The flowerstalks are thick and juicy and covered with small narrow leaves. It has silky-haired seeds like a dandelion.

Petasites sagittatus, or Arrow-leaved Coltsfoot, has huge leaves with two very marked pointed lobes at the base. Its flower-heads grow compactly at the top of stout stalks, and are white and fragrant.

Petasites frigidus, or Arctic Coltsfoot, has few blossoms, a scaly stem, and very irregularly lobed leaves. The foliage of all the Coltsfoots is green and smooth on the top, and white and woolly underneath. They are coarse uninteresting plants. 


\section{WHITE THISTLE}

Carduus Kelseyi. Composite Family.

Stems: tall, striate. Leaves: alternate, linear, sinuately toothed. Flowers: heads in a leafy spike subtended by linear, cut, bristly-fringed, cobweb-hairy leaves. Fruit: pappus of long plumose bristles.

The stems of this Tall Thistle are very cobweb-woolly, and the leaves are toothed and fringed with weak spines, being green above and cobweb-hairy beneath. The creamcoloured flower heads grow several together in a leafy spike.

Cardus foliosus, or Leafy Thistle, has erect robust stems, and is very leafy up to the few somewhat woolly flower heads, which have a pale corolla with lobes equalling the throat. The leaves are elongated, toothed with rigid prickles and cobweb-woolly beneath. 



\title{
WILD FLOWERS OF THE NORTH AMERICAN MOUNTAINS \\ SECTION V
}

\author{
PINK TO RED FLOWERS
}





\section{SECTION V}

\section{PINK TO RED FLOWERS}

\section{PINK GARLIC}

Allium cernuum. Lily Family

Bulbs clustered on a short rootstock, narrowly ovoid, with a long neck. Stems: scape slender. Leaves: linear, channeled, or nearly flat. Flowers: umbel many-flowered, nodding, subtended by two short deciduous bracts; perianth segments ovate, acute; stamens and style exserted.

These clusters of tiny pink flowers, which grow on long slender stalks that bend over abruptly at the top are characteristically odorous, as may be readily understood, since allium is the Latin for "garlic." From ten to forty flowers form the umbel upon each stalk, and both the awl-shaped stamens and the style protrude far beyond the segments of the perianth.

The leaves are long and extremely narrow, in fact, grasslike, being channeled or flat and terminating either in a blunt or a fine point.

\section{PINK TWISTED-STALK}

Streptopus roseus. Lily Family

Stems: from a short stout rootstock corered with fibrous roots, simple or sparingly branched. Leaves: lanceolate to ovate, abruptly acuminate, sessile by a broad, rounded, clasping base, the margins finely ciliate. Flowers: peduncled, segments of the perianth lanceolate, the tips spreading. Fruit: a red oval berry.

This plant is a near relation of $S$. amplexifolius described in the White to Green Section. It differs from the fore- 


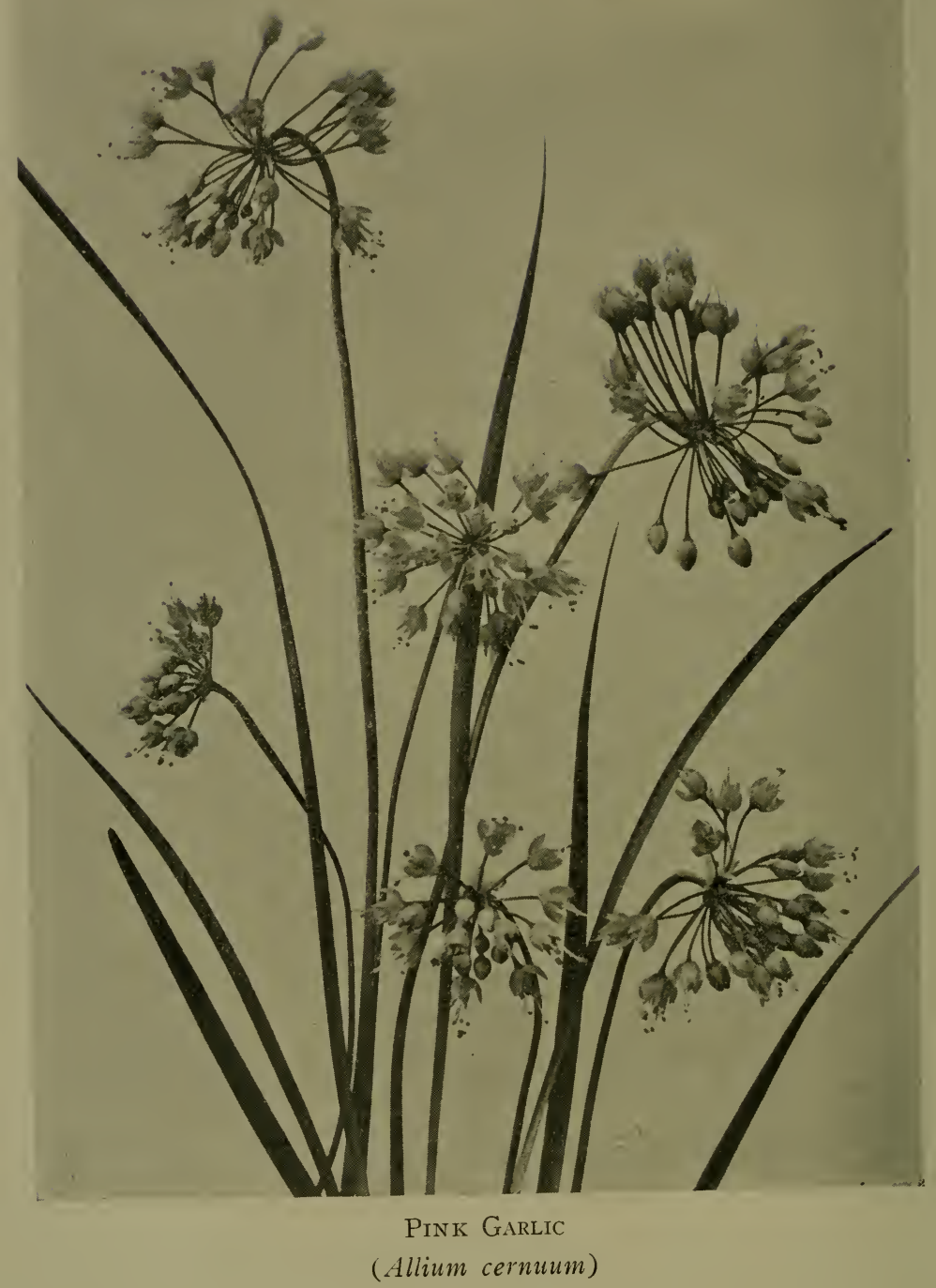


going, however, in several essential particulars. In the first place, it is a smaller plant, has dull purple-pink pendent bells, and is nearly always one-flowered. Then, too, the tiny peduncles are not sharply twisted as in S. amplexifolius, but bend downwards in a graceful curve. The rosy-hued bells are quite hidden beneath the leaves and may be seen only when the long stems are turned over. These bells are streaked outside and lined inside with deep rose colour.

\section{SHORT-STEMMED TWISTED-STALK}

Kruhsea streptopoides. Lily Family

Stems: smooth, simple, from an extensively creeping rhizome with a few fibrous roots at each node. Leaves: ovate-lanceolate, acute, the upper sessile, the lower clasping at the base. Flowers: stellate, solitary on curved stalks in the axils at the backs of the upper leaves. Fruit: a globose red berry.

The stems of this plant grow four to eight inches high from a creeping rhizome. The leaves are narrowly eggshaped, bright green and shining on both sides, and the little dark rose-coloured flowers grow on curved thread-like stalks at the backs of the upper leaves. The tiny sepals and petals are both wine-coloured at the base, the petals having yellowish-green reflexed tips. The berries are rounded and bright red. The Short-stemmed Twisted-stalk closely resembles the Pink Twisted-stalk, but differs from it in having a much more slender rootstock and shorter stems.

\section{FLY-SPOTTED ORCHIS}

\section{Orchis rotundifolia. Orchid Family}

Stems: slender. Leaves: leaf solitary, orbicular to oval, with one or two sheathing scales below it. Flowers: spike two-to-ten flowered, subtended by small bracts; sepals lateral ones spreading; petals similar to the sepals; lip longer than the petals, three-lobed, the middle lobe larger, dilated, notched at the apex; spur slender, shorter than the lip. 


\section{PLATE XLIV}

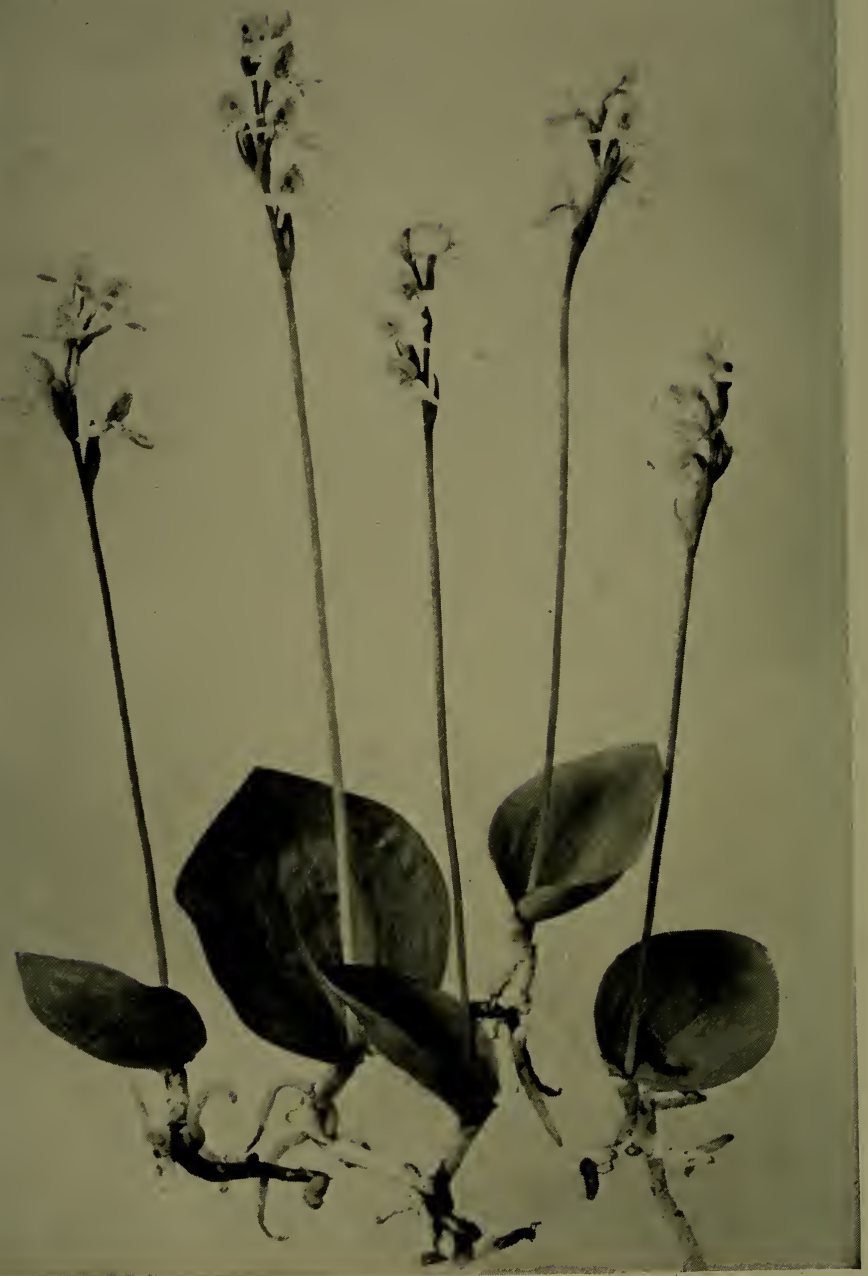

Fly-SPOTted ORChis

(Orchis rotundifolia) 
A lovely pale pink orchis, with a single roundish leaf growing at the base and roots composed of fleshy fibres. The clusters of flowers are slightly fragrant. Each blossom has a large, protruding, flat lip of palest pink, spotted with rose or purple, and divided into three lobes, the centre one being notched. A wing-like sepal stands out on either side, and the small petals and sepals are all pink, the arched petal that is bent down over the stamens being spotted with rose-purple like the lip. It is found in moist places and grows to full perfection where very wet ground combined with a full exposure to the sun is possible.

\section{CALYPSO}

\section{Calypso bulbosa. Orchid Family}

Stems: with two or three membranaceous sheaths, and a linear bract at the summit. Leaves: leaf solitary, broadly ovate, petioled. Flowers: drooping, pedicelled; sepals and petals lanceolate, acuminate, long lip inflated, saccate, with two short spurs below the apex.

A solid bulb and coralloid roots, a single stem sheathed by two or three loose brownish-green scales and surmounted by a single narrow bract, a solitary broad leaf at the base, and a single lovely mauvish-pink orchid blooming at the summit,- such is the Calypso.

The sepals and petals of this dainty flower are like fairy wings, its large sac, striped and mottled with deep rose colour and variegated with yellow spots, tufted by fine white hairs, resembling the body of some gay insect; thus the blossom appears to be poised lightly upon its stem like a beautiful butterfly ready to flutter a way at our approach. This effect is heightened by the fact that it grows in the deep cool forests, where its exquisite fragrant flowers form the only spots of vivid colour and where it is sheltered by the vines 
and mosses that cluster together in those damp shady places that are the favourite haunts of this orchid.

When Mrs. Hemans wrote

"There's not a flower but shows some touch,

In freckle, freck, or stain,

Of His unrivalled pencil,"

she must have had in mind the marvellous painted slipper of the Calypso, for its delicate veinings in finely pencilled pattern are surely the wonderful work of the Great Masterhand.

The name Calypso denotes that the plant is dedicated to the ancient goddess of that name.

\section{SWAMP PERSICARIA}

Polygonum Muhlenbergii. Buckwheat Family.

An aquatic herb, perennial by long creeping or horizontal rootstocks. Stems: erect, commonly simple, channelled, enlarged at the nodes. Leaves: oblong-lanceolate, acute or acuminate at the apex, rounded or cordate at the base, ocreæ cylindric. Flowers: small, in a terminal raceme, calyx rose-colour. Fruit: achenes lenticular, broadly obovoid, very convex, black, smooth, shining.

The dense rose-coloured spikes of the Swamp Persicaria may frequently be seen rising above the surface of some forest pool, or fringing its borders. As Emerson has so aptly described it,

“Rosy Polygonum, lake-margin’s pride,"

is one of the prettiest aquatic plants amongst the mountains. The stems are channeled and enlarged at the points from which the leaves grow; sometimes they float, and sometimes they are immersed beneath the waters. The leaves are long-shaped and smooth. 


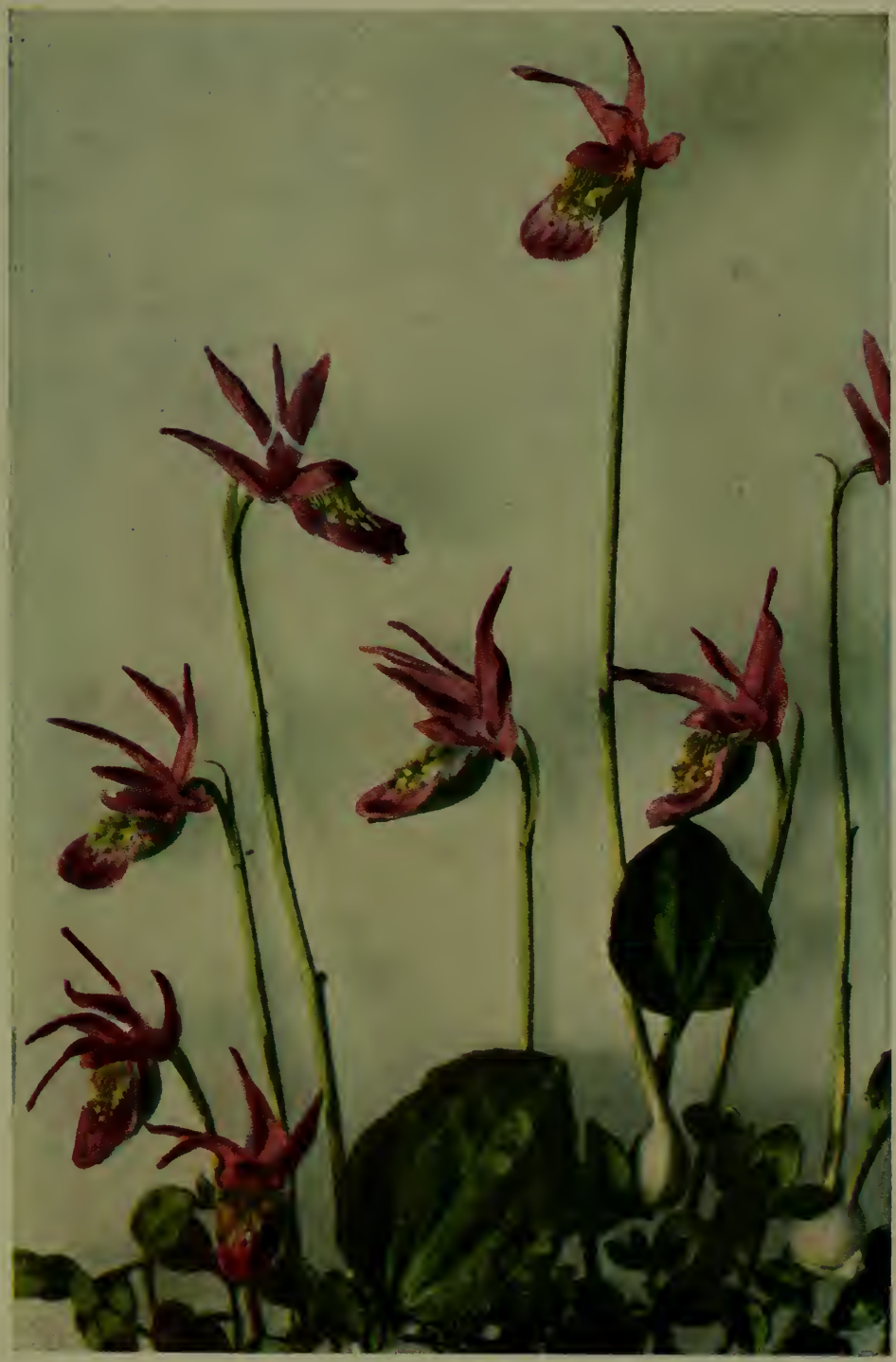

Calyrso

(Calypso bulbosa) 



\section{MOSS CAMPION}

Silcne acaulis. Pink Family

Closely cæspitose, one to two inches high. Leaves: linear, crowded. Flowers: small, solitary, subsessile or slightly raised on naked curved peduncles; calyx narrowly campanulate; petals pink, purple or white. obcordate.

The Moss Campion will be found by those who climb to great altitudes, for it grows near the highest summits of the mountains and has been discovered at the immense elevation of 10,000 feet. It is a dwarf arctic-alpine plant. The tiny leaves, which are very numerous and extremely narrow and pointed, distinguish it from Saxifraga oppositifolia, or Mountain Saxifrage, which has similar flowers but distinctly broader leaves.

Close to the eternal snows, where the last line of vegetation grows prostrate upon the earth, so rare the air, so scarce and poor the soil,

"There, cleaving to the ground, it lies

With multitude of purple eyes

Spangling a cushion green like moss."

Surely Wordsworth must have found the Moss Campion amongst his beloved Grasmere Hills, otherwise he could not have penned so perfect a description of its starry flowers with their five pink, purple or very occasionally white petals wide-blown by the mountain breeze.

The Moss Campion has a very large tap-root, and springing from it are the slender branching stems, which form dense tufts from six to twenty inches in diameter and resemble a coarse moss. Down into these tufts the flowers are closely set. 


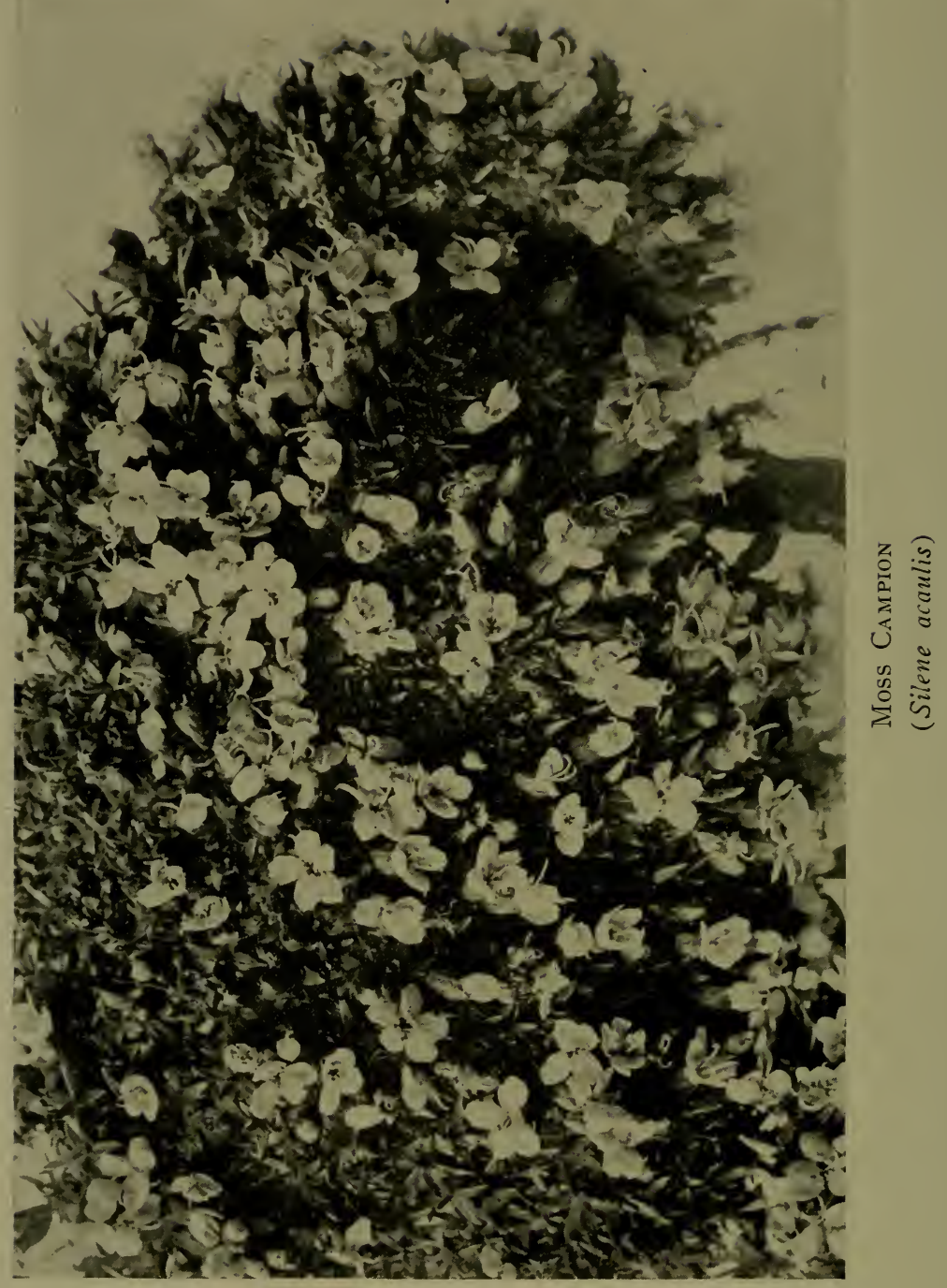




\section{BITTER-ROOT}

\section{Lewisia rediviva. Purslane Family}

Stems: scape short, jointed, bracteolate near the middle. Leaves: linear-oblong, subterete, smooth, glaucous. Flowers: sepals six to eight, distinct, broadly ovate, unequal, partly scarious, petals eight to sixteen, narrowly oblong. Fruit: capsule circumsessile at the base, then bursting irregularly, seeds numerous, black, shining.

The large showy rose-pink flowers of this Lewisia are very lovely. The oblong, narrow leaves, which are crowded at the crown of the thick caudex, are smooth and covered with a whitish bloom; while from a fleshy root grow the one-flowered buff-coloured scapes that are jointed and have buff bractlets near the middle.

\section{STRIPED OREOBROMA}

Oreobroma cotyledon. Purslane Family

Stems: scapose, stout, from a fleshy root. Leaves: flat, spatulate to cblanceolate. Flowers: in a short cymose panicle, sepals two, persistent, fetals five to ten, oblanceolate. Fruit: capsule obscurely two to four valved, many-seeded.

The flowers of this Oreobroma, which are deep rosecolour with an orange stripe in the centre of each petal, grow in short cymose panicles, terminating the rather stout stems, which latter are six to twelve inches high, jointed at the base, and usually have two pairs of bracts below the inflorescence. The leaves, which are flat and spatulate or oblanceolate, are imbricated in a dense rosulate tuft. The roots of this perennial plant are thick and fleshy.

\section{WESTERN COLUMBINE}

Aquilegia formosa. Crowfoot Family

Stems: branching from a simple, fleshy, fusiform root. Leaves: lower ones triternate on long petioles, upper ones sessile or reduced to simple 
bracts; leaflets broadly cuneate, three-cleft. Flowers: red, pendulous in anthesis; sepals spreading or reflexed, abruptly narrowed to a short claw; spurs same length as sepals.

A large gaudy flower of which it has been said:

"The graceful columbine, all blushing red,

Bends to the earth her crown

Of honey-laden bells."

The Western Columbine does not seek the light dry soil amongst the rocks, as do its sisters, the Yellow and the Blue Columbines, but prefers a moist habitat, where its brilliant pendulous blossoms make the valleys gay.

It has bright red and gold petals, growing alternately with its five red sepals. These petals, shaped like inverted cornucopias, are usually edged as well as lined with yellow, their upper ends being narrowed to terminal tubular spurs. Linnæus gave this plant its generic name, derived from the Latin aquila, owing to the fancied resemblance of its spurs to the claws of an eagle; while Columbine is taken from columba, "a dove," and refers to the resemblance of its nectaries to a circle of doves in a ring around a dish, which was a favourite device amongst sculptors and painters in ancient times. The numerous stamens and long slender styles of the pistils protrude like pretty golden tassels from each flower. The foliage of this tall plant, which usually grows from two to three feet high, is very abundant and fern-like; dark green on the top, and pale and whitish underneath. The larger leaves grow on long foot-stalks and are divided into three leaflets, which in their turn are three-tofive lobed and have unequally toothed edges.

There are not very many really red mountain wild flowers, and therefore the traveller takes an especial delight in finding the Western Columbine, since, like Eugene Field, he 


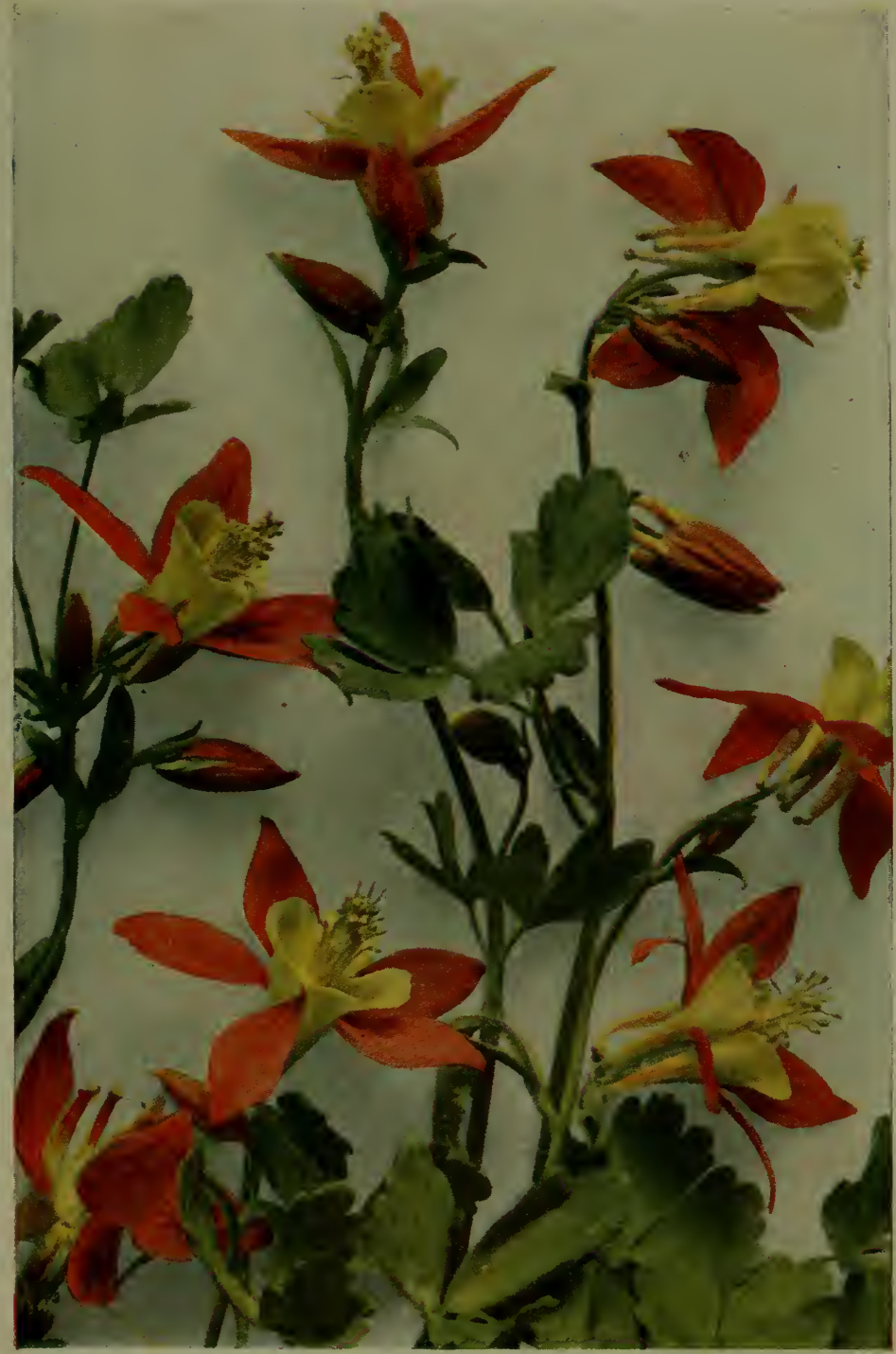

Western Columbine

(Aquilegia formosa) 

loves a blossom of " any colour at all so long as it's red." It is a plant extremely attractive to bees, butterflies, and birds, which come to sip its sweets.

\section{WILD BLEEDING-HEART}

Dicentra formosa. Fumitory Family

Stems: from the apex of thick, almost naked, creeping rootstocks. Leaves: twice or thrice ternately compound, the ultimate divisions narrow and incisely pinnatifid. Flowers: pale magenta, in compound racemes at summit of scapes; corolla ovate-cordate, with connivent spurs; petals united up to and above the middle.

This plant resembles, in miniature, the lovely pink and white Bleeding-heart so popular in old-fashioned gardens; but its dull magenta-pink flowers are not nearly so attractive in appearance as those of its beautiful cultivated cousin. The only charm of the wild species lies in the grace of its slender stems, which bear numerous pendent heart-shaped blossoms along their drooping lengths, and its finely dissected foliage.

Dicentra uniflora, or One-flowered Bleeding-heart, has soft green leaves which are ternately divided, the three to seven divisions pinnatifid into a few spatulate lobes. The scapes grow only three to five inches high from a close bundle of spindle-shaped and perpendicular fleshy tubers; they are bracted, and one, or rarely two-flowered. The creamy pink flowers have two small scale-like sepals, and the two outer petals are gibbous-saccate at the base, their recurving tips much longer than the body, while the small hollowed tips of the two inner spoon-shaped petals are united at the apex, and form the cavity containing the anthers and stigma. 


\section{LYALL'S ROCK CRESS}

\section{Arabis Lyallii. Mustard Family}

Stems: simple, more or less stellate-pubescent, from a branched perennial caudex. Leaves: the lower spatulate, the stem leaves lanceolate. Flowers: in rose-mauve racemes. Fruit: seeds orbicular, narrowly winged in one row.

The several stems grow from the same root and the lower leaves are spatulate, those on the stems being narrow and slightly lobed at the base. The rose-mauve flowers are very pretty growing in an elongated scattered cluster, and the pods are erect, slender and straight. This plant is found at high altitudes.

\section{ROSEWORT}

\section{Sedum roseum. Orpine Family}

Stems: erect, simple, glabrous. Leaves: oval, obtuse at the apex, dentate. Flowers: cyme terminal dense; petals longer than the oblong narrow sepals; staminate flowers with eight stamens, the pistillate ones with four carpels.

The small purplish-red flowers of this short thick plant are set in a cluster at the top of the stems, which are covered with many small leaves. It grows in the crannies between the rocks and on stony slopes.

\section{WOODLAND STAR}

\section{Lithophragma tenella. Saxifrage Family}

Stems: slightly glandular-pubescent. Leaves: trifoliolate, leaflets two to three parted, two to three lobed segments cuneiform. Flowers: few in a capitate bulblet-bearing raceme. Fruit: seeds short-oblong, rough-tuberculate.

The slender stems of this Lithophragma which branch from the base are slightly roughened by minute hairs. The leaves are trifoliolate, and the pale pink flowers grow in a 
capitate or somewhat elongated cluster which is frequently bulblet-bearing.

\section{SKUNK CURRANT}

Ribes laxiflorum. Saxifrage Family

Stems: cæspitose, erect or ascending. Leaves: triangular, truncate or cordate at the base, deeply five-lobed, doubly serrate. Flowers: five to fifteen flowered, raceme finely pubescent, calyx rotate, lobes broadly spatulate. Fruit: a berry.

The stems of this Currant are spineless, and the leares are deeply five-lobed, doubly toothed and frequently resinousdotted beneath, they grow on long stalks abruptly dilated at the base. The dull pinkish-red flowers have a rotate calyx with broad spatulate lobes and narrow spatulate petals, and the fruit is a purple-black berry covered with a whitish bloom. Altogether this plant, which grows in wet shady places, is a handsome species, and it is, moreover, well named, because if you bruise the stems or leaves they emit a strong skunk-like odour, while the berries themselves are also extremely nasty to the taste.

\section{PINK SPIRAAA}

Spirca densifora. Rose Family

Stems: reddisl-brown. Leaves: ovate to elliptic, serrulate at the apex, entire below, narrowed to a very short petiole. Flowers: small in dense leafy-bracted corymbs terminating the branches. Fruit: five carpels distinct, not inflated, seeds small linear with thin membranaceous testa.

The reddish-brown stems of this Spiræa, which are extremely brittle, shed their thin bark annually. The elliptical leaves are dark green on both sides, minutely toothed at the apex and even-margined towards the base which is narrowed into a short stalk. The tiny rose-red flowers are 
closely crowded in roundish leafy-bracted flat-topped clusters at the ends of the many branches.

\section{LONG-PLUMED AVENS}

Geum triflorum. Rose Family

Stems: scape simple, three-flowered at the summit. Leaves: basal ones tufted, petioled, interruptedly pinnate, with many small leaflets interspersed among the numerous obovate larger ones; leares of the scape two opposite, small, sessile pairs. Flowers: of five pale purplishpink petals surrounded by a persistent red calyx, five-bracteolate and five lobed; bractlets linear, slightly longer than the lanceolate, acute, erect lobes. Fruit: head sessile; style filiform and strongly plumose.

A very curious plant. Its general appearance is that of bearing three large dull red buds on a three-branched red stem, with a number of little red bracts clustered at the fork; for the pale pink or yellowish petals are so snugly hidden away within the calyx that you do not observe them at a casual glance. The closed calyx forms these fat buds, which have five slender reflexed bracts set between their lobes, and from their pointed tips protrude a number of yellow stamens.

When the petals and sepals fall off the long plumose tails that adorn the ripened heads of the Avens are exceedingly attractive. Many long finely cut leaves grow at the base of this plant.

\section{ARCTIC RASPBERRY}

Rubus arcticus. Rose Family

Stems: erect, branched at base. Leaves: trifoliolate; leaflets sessile, rhombic-ovate, unequally serrate. Flowers: solitary; sepals acute, equalling the obovate entire petals. Fruit: light red, of several drupelets, edible.

A dwarf alpine Raspberry, about six inches high, that grows at an altitude of 8000 feet. It has a few large threeparted leaves and one or two rose-pink flowers composed of 
six long, widely separated petals. The long thin roots strike straight down into the earth, and therefore when you attempt to pick one of these little plants it usually comes up altogether out of the ground in your hand. The Arctic Raspberry has no prickles.

Rubus spectabilis, or Salmonberry, has shrubby branching stems, yellowish shreddy bark, and is copiously armed when young with straight stout prickles. The leaves are usually trifoliolate, the leaflets being deeply toothed, and the pinkish-red flowers are nearly always solitary, large and showy. The Indians are very fond of the sweet juicy red or yellow berries.

\section{PRICKLY ROSE}

Rosa acicularis. Rose Family

Stems: densely prickly. Leaves: pinnate; leaflets large, five to seven, oval-lanceolate, coarsely toothed. Flowers: solitary; petals pink, broadly obovate; sepals entire, acuminate, persistent and erect upon the fruit. Fruit: globose, glabrous.

The bush on which this Rose grows is about three feet high and bears lovely, fragrant, pale pink flowers. The leaves are large and very dark green, and the stems are covered with many tiny, fine, straight prickles. All the wild Roses display a preference for the number five, having five petals and five sepals.

No flower in the world has been so famous in poetry and song as the Rose. Its beauty and fragrance have won for it an honoured place in the annals of history, in classic lore, and in the glowing pages of romance.

"Was ever blossom lovelier than the rose?"

Surely not. Nor can we agree with Juliet when she says: 
"That which we call a rose

By any other name would smell as sweet."

For to us the Rose symbolizes those things which are tender and exquisite in life, and the sweet wild dweller in the forest is the fairest flower of them all.

"If June were mine, I'd weave for you-

Of roses red and skies of blue,

Of golden sun and orchard sheen,

Of blossom-fretted damascene-

A veil of every petal-blue.

"And from the morning mists of dew

Distil a fairy stream, that through

The woods should wend a way serene,

If June were mine.

"And, ere the purple dusk anew

The curtains of the sunset drew,

Adown the river's dream demesne,

I'd paint a path incarnadine,

And drift into the dawn with you,

If June were mine."

Rosa Macounii, or Macoun's Rose, is another species which grows among the mountains. Note that it has small leaves, and that on its stems grow a few large, widely separated, hooked thorns. Otherwise it resembles $R$. acicularis, and the flowers of the two bushes are almost identically alike. When

$$
\begin{aligned}
& \text { "The last rose of summer, } \\
& \text { Left blooming alone," }
\end{aligned}
$$

hangs on the bush surrounded by the fallen petals of her companions, then

"Scarlet berries tell where bloomed the sweet wild rose,"

and Nature spreads a feast of ripe red fruit for the birds of the air. 
I cannot refrain from closing this brief mention of the Rose with a quotation from a poem by Isabella Valancy Crawford, the sweetest singer of songs Canada ever knew :

"The rose was given to Man for this:

$\mathrm{He}$, sudden seeing it in later years,

Should swift remember Love's first lingering kiss,

And Grief's last lingering tears.

"Or, being blind, should feel its yearning soul

Knit all its piercing perfume round his own,

Till he should see on Memory's ample scroll

All roses he had known."

Rosa gymnocarpa, or Tiny Rose, has rather weak stems with straight, slender, scattered spines on a prickly rachis, and five to nine toothed leaflets. The pale pink flowers are very tiny and sweet-smelling, and the fruit is oblong and smooth.

\section{RED CLOVER}

\section{Trifolium pratense. Pea Family}

Stems: ascending, somewhat hairy; pistules broadly lanceolate, membranaceous, nerved, setaceously acuminate. Leaves: leaflets obcordate, nearly entire. Flowers: heads ovate, dense, nearly sessile, bracteate; teeth of the calyx setaceous, hairy, the lower one much longer than the other four; petals purple-red, all united into a tube at the base. Not indigenous.

Thoreau speaks of the fields blushing with Red Clover " as the western sky at evening." Every one knows the Clover. Every one has walked ankle-deep in meadows rich with its red flowers. Some of us are even fortunate enough to " live in clover,"- - but not all! It is a quaint conceit of the Red Clover to fold its leaves in sleep each night, the two side leaflets drooping downwards together and the terminal one bowed over them. 
The name Clover probably comęs from the Latin clava, meaning "club," and refers to the possible resemblance between the trefoil leaf and the three-headed club of Hercules. The "clubs" on playing cards are, no doubt, also an imitation of the clover leaf.

The Clover is believed by many people to be the ancient "shamrag" of Ireland, though others - with perhaps equal authority - claim that the National Flower of the Emerald Isle, chosen by St. Patrick to illustrate the doctrine of the Trinity, was originally the IVood-sorrel (Oxalis Acctosella) whose quaint name of Allelujah refers to the religious significance of its triple leaf. This is an introduced plant.

\section{MACKENZIE'S HEDYSARUM}

Hedysarum Mackeniii. Pea Family

Stems: suberect, simple or branched, minutely pubescent. Leaves: five to eight pairs, oblong. Flowers: seven to thirty, loosely flowered; bracts subulate; teeth of the calyx as long as the tube.

A bright rose-magenta wild Pea that grows to a height of two feet in the mountain meadows. It is a large, spreading, handsome plant.

\section{CAROLINA CRANE'S BILL \\ Geranium carolinianum. Geranium Family}

Stems: erect, much branched from the base. Leaves: petioled, reniform-orbicular in outline, deeply cleft into five to nine oblong, cuneate, lobed segments. Flowers: in compact clusters; petals pink, obcordate, equalling the awned sepals.

This wild Geranium is very like the Herb Robert, and has the same dull pink flowers veined with deep rose. The Greek name of the plant means " a crane," and the common name Crane's Bill denotes the long grooved beak composed of five styles that cohere at the top. The calyx is formed of 
five pointed sepals, and the corolla of five indented petals. The whole plant is covered with fine gray hairs and has an extremely strong smell, caused by a resinous secretion. Its leaves are roundish in form and deeply cleft; the long stalks are brittle and quite red where exposed to the sunlight. Sometimes the flowers are white.

Geranium Bicknellii, or Bicknell's Geranium, resembles the preceding species, but is a taller, more slender plant. The leaves are angulate in outline, the segments being narrowly oblong and deeply cleft. The pale pinkish flowers grow in loose clusters, and the beaks are not so long-pointed as those of the Carolina Crane's Bill.

\section{GREAT WILLOW-HERB}

Epilobium angustifolium. Evening Primrose Family

Stems: erect, simple or branched, glabrous. Leaves: alternate, lanceolate, entire, pale beneath, acute at the apex, narrowed at the base, thin. Flowers: magenta, in terminal spike-like racemes; petals four, entire, spreading.

The tall strong stems of this striking plant rise to an average height of three feet, though frequently tallcr, and terminate in long racemes of bright purplish flowers, in which the number four is conspicuous, each one having a very long calyx-tube divided into four segments and four large, rounded, wide-open petals. The four-cleft stigma at the apex of the long style is extremely prominent. The mid-ribs of the leaves, the stems, the buds, and the calyxtubes are all a dull red; and when the seed ripens the long narrow vessels burst open lengthwise and send afloat in the air clouds of white silky tufts, to each of which is attached a seed that ultimately falls to earth seeking some new spot favourable to its development. 
The name Epilobium signifies " upon a pod," and probably refers to the fact that the flowers grow on the ends of the long pods. Willow-herb refers to the fact that the leaves resemble those of the IVillow.

Wild Fire, or Fire Weed, is another common name for this plant, and a very appropriate one, too, for it is marvellous how quickly these stately, handsome flowers will cover over and beautify those tracts of country that have been charred and desolated by forest fires.

"Strange flower, thy purple making haste

To glorify each blackened waste

Of fire-swept land

Is with a blessed meaning fraught,

And we - when pain hath fully wrought -

Shall understand."

Epilobium latifolium, or Water Willow-herb, is a very handsome species which grows in wet places and marshes, or near water. It may always be recognized by its large bright magenta flowers and the glaucous appearance of the stems and leaves, - that is to say, by the whitish bloom which covers them. The leaves are also thick and very soft, entire, sessile and narrow.

Epilobium anagallidifolium, or Mountain Willow-herb, is a tiny dwarf plant, from two to six inches high, growing on lofty summits. It has small magenta or sometimes white flowers, which nod at the top of the slender single stems, up which a few pairs of little oblong leaves grow. It has been found at the immense altitude of 10,000 feet.

Epilobium Hornemanni, or Hornemann's Willow-herb, is a common species which grows about eight inches high, bears small purplish-pink or white flowers that are strongly veined, and has very long slender capsules, or seed vessels, 


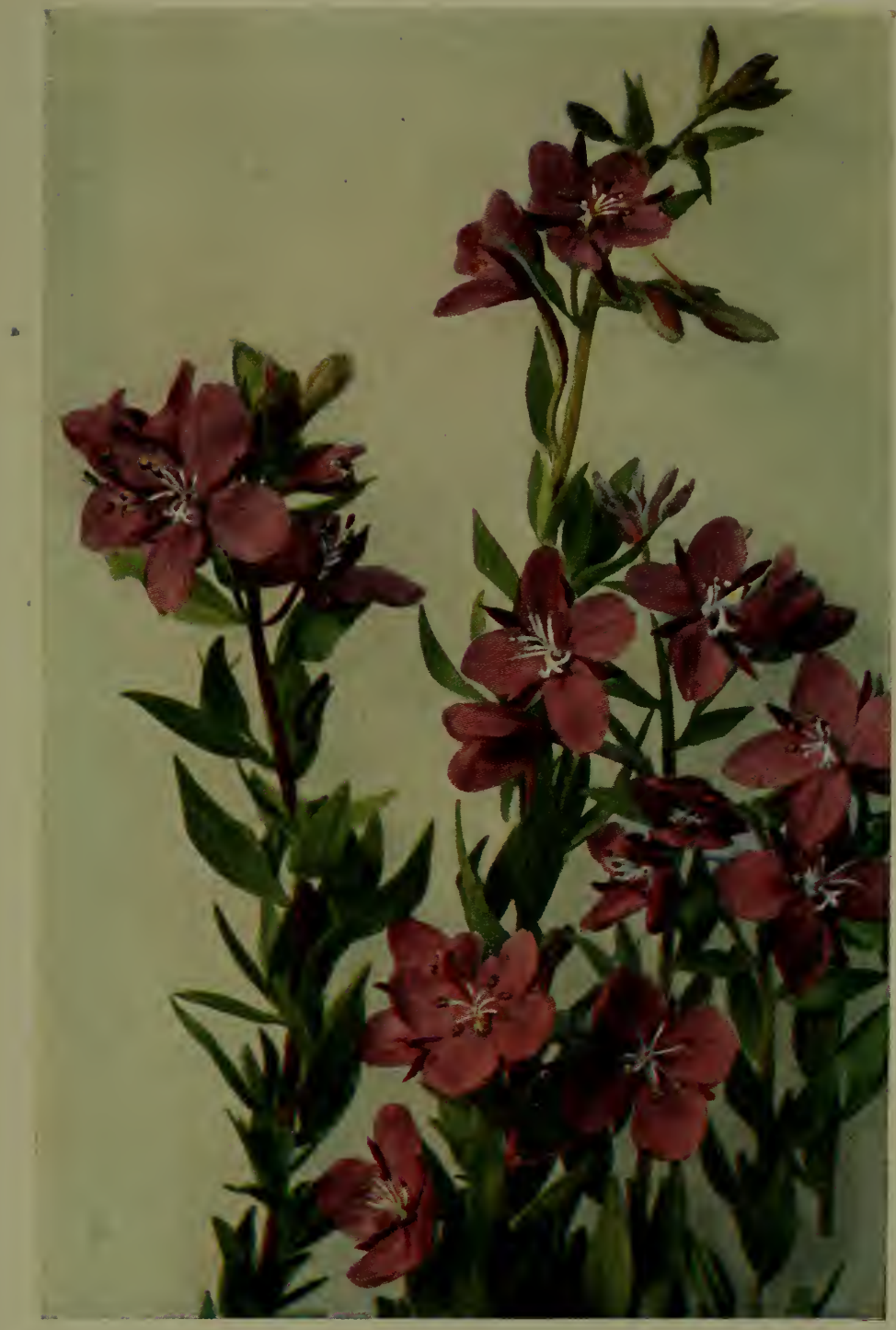

WATER WILLOW-HERB

(Epilobium latifolium) 

on its reddish stalks. The pretty little blossoms are surrounded by a green calyx and surmount the narrow capsules, which are usually from an inch to two inches long. The leaves are short-stalked, ovate, blunt at the apex, narrowed at the base, and nearly even-margined.

Epilobium paniculatum, or Panicled Willow-herb, has stems loosely forked in pairs, and the leaves are chiefly alternate, narrow, clustered in the axils, sparingly toothed, pointed and tapering into a slender winged stalk. They are frequently folded along the midrib. The mauve flowers are scattered towards the ends of the erect stems.

Epilobium clavatum, or Few-flowered Willow-herb, is taller than the preceding species, and the leaves are broadly ovate, very blunt at the apex and rounded at the base. The rose-coloured flowers grow nearly erect and the capsules are an inch long.

Epilobium adenocaulon, or Northern Willow-herb, is much branched and bushy and has lance-shaped, sparingly toothed, leaves, both the stems and leaves frequently being purplish. The somewhat nodding pinkish flowers are numerous and grow in the axils of the leaves.

\section{PIPSISSEWA}

Chimpalphila umbellata. Heath Family

Stems: extensively trailling, horizontally subterranean. Leaves: spatulate, sharply serrate. Flowers: several, umbellate or subcorymbose. Fruit: an erect globose capsule.

The trailing stems of the Pipsissewa, or Prince's Pine, run horizontally under the earth and have tiny roots. The bright shining evergreen leaves are spatulate and very sharply toothed, while the pinkish flowers, which grow in 
a spreading cluster, are small and marked with a deep pink ring. The filaments are fringed with marginal hairs.

Chimaphila Menziesii, or Spotted Prince's Pine, is not quite so tall as the preceding species. It has small oblong leaves, pointed at both ends, and sharply toothed, the upper surface being usually spotted or mottled with white. The peduncle bears one to three flowers, which latter are a dull pinkish creamy-white.

\section{BOG WINTERGREEN}

Pyrola asarifolia. Heath Family

Stems: scape six-to-twelve flowered. Leaves: coriaceous, shining above, reniform, wider than long, crenulate. Flowers: racemose, nodding; petals five, obtuse: calyx five-parted, persistent, the lobes triangular-lanceolate; stamens declined; style declined and exserted.

The tall red stalk of this Wintergreen, with its numerous nodding rosy blossoms, is exceedingly attractive, especially as it grows in the deep moist woods, where few flowers flourish owing to the absence of all sunlight. Very fragrant also is this quaint plant, to which the name of Wintergreen has been given on account of its evergreen foliage. The long out-curved style, which protrudes far beyond the floral cup, is green, and has a dull red stigma, while the ten stamens are tipped by dark, slightly beaked anther-sacs. The calyx is entirely of a deep red hue, and the petals are bright-coloured at the outer edges, shading into palest pink in the centre. The leaves grow in a cluster at the base and are thick, tough, and glossy. A few narrow little bracts cling to the flower-stalks.

Sheltered from the wind and the sun, half hidden by mosses and tangled undergrowth, but always preferring a 


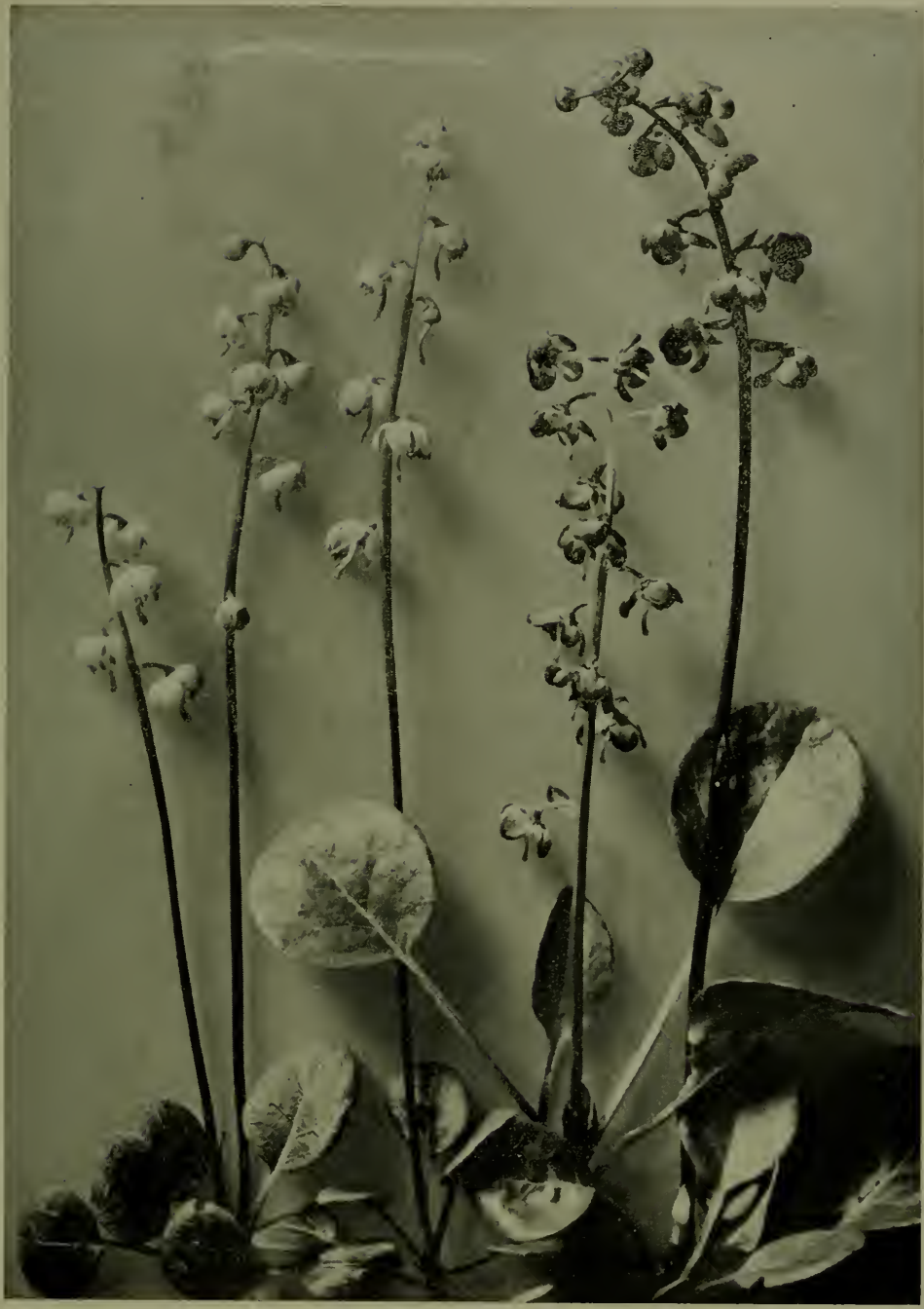

Red Wintergreen (Pyrola asarifolia var. incarnata) Green-Flowered Wintergreen (Pyrola chlorantha) 
damp spot to a dry one, the Bog IVintergreen grows in close companionship with the lovely One-flowered Wintergreen, the Long-bracted Orchis, and the Butterwort; and if you know the

"Secret paths that thread the forest land,"

you may find them in profusion, mingled at your feet by happy chances,- - a gay holiday throng.

Pyrola asarifolia iar. incarnata, or Red IVintergreen, has broadly oval leaves, rounded at the base, which are dull, thick and blunt at both ends. The rose-red flowers nod in a slender raceme and the style and stamens are declined. The chief difference between this species and Pyrola asarifolia is that its leaves are quite dull, almost leathery, while those of the Red Wintergreen are polished and shining.

\section{SMOOTH MENZIESIA}

\section{Menziesia glabella. Heath Family}

Leaves: alternate, obovate, obtuse and glandular-mucronate at the apex, pale glaucous and glabrous beneath, sparingly pubescent above, the margins entire, crenulate, ciliolate. Flowers: one to five in umbels, cream and pink, spreading, becoming erect; calyx five-lobed; corolla urn-shaped, four toothed; stamens eight, included. Fruit: seeds long-appendaged at each end.

If you wish to be quite certain that the shrub before you is really Menzicsia glabella, just break off a branch and smell it, and you will at once perceive the peculiar pungent odour of the skunk emanating from its stems and foliage. The bush grows erect to the height of six feet and bears abundant foliage. The leaves are sma1l, oval, and pale green, and have even wavy hairy margins. The flowers are little roundish pink and creamy urn-shaped bells, which terminate the long slender stalks, and are four-lobed, having 
eight stamens within their cups. They grow in umbels at the ends of the twigs, and also encircle the stems just below the topmost clusters of leaves. When in fruit the seeds are characterized by long appendages at each end.

Menziesia ferruginea, or Scaly Menziesia, differs from the preceding species in having strigose chaffy ferruginous scales on the young parts of the straggling branches, while the somewhat egg-shaped leaves are thickly covered with rusty appressed straight stiff hairs above, and are pale green and smooth beneath. The flowers are very like those of the Smooth Menziesia. Archibald Menzies, after whom the plants are named, brought the original species from the North West Pacific Coast when he sailed there with Captain Vancouver on his famous voyage of discovery in $I 790$.

\section{TRAILING ALPINE AZALEA}

\section{Loiseleuria procumbens. Heath Family}

Stems: tufted, much branched, diffuse. Leaves: mostly opposite, linear-oblong, crowded, entire, the margins strongly revolute. Flowers: one to five from terminal coriaceous buds. Fruit: a capsule, subglobose.

The Trailing Alpine Azalea is a very attractive though rather rare plant among the mountains. It has lovely little pink bells with purplish sepals growing on erect stalks at the ends of the branches, and crowded dark green leaves which are a paler colour beneath, and have rolled back margins and a very prominent midrib on the under side. There are many botanical romances and interesting geographical suppositions connected with the history of the Heath Family, the presence of some of whose members in Ireland, Cornwall, the Spanish Peninsula and the Azores point to a confirmation of the belief of ancient chroniclers 
in the existence of Atlantis and Lyonesse, those great submerged continents which were perhaps the original home of the Heaths.

\section{SWAMP LAUREL}

Kalmia polifolia. Heath Family

Branches glabrous, ascending. Leaves: opposite, nearly sessile, linear-oblong, margins strongly revolute. Flowers: in simple terminal umbels; bracts large; sepals ovate, nuch imbricated, persistent.

Growing usually about a foot high, though frequently only a few inches tall, it bears at the ends of its slender branches large clusters of bright rose-red or magenta flowers, which have a five-lobed corolla and ten stamens, whose filaments are slightly curved, by reason of the red-brown anthers being caught in the ten pouches which are placed below the limbs, or expanded lobes of the corolla. If you flip the outer edge of the Swamp Laurel gently with your finger, you will see the little stamens spring upright, sending forth a shower of pollen from their anthers in the process. The heart of the flower is usually pale green. Its evergreen foliage is dark green above and covered with a white bloom beneath. The Swamp Laurel, as its common name implies, grows in marshy ground.

\section{RED MOUNTAIN HEATHER}

Bryanthus empctriformis. Heath Family

Densely much branched from the base. Leaves: strongly revolute, thickened and rough margins. Flowers: umbellate, subtended by foliaceous and rigid bracts; corolla deep rose colour, campanulate, fivelobed.

The Mountain Heathers - there are no true Heathers indigenous to this continent - are low branching shrubs.

Bryanthus empetriformis grows abundantly in the moun- 
PLATE XLVII

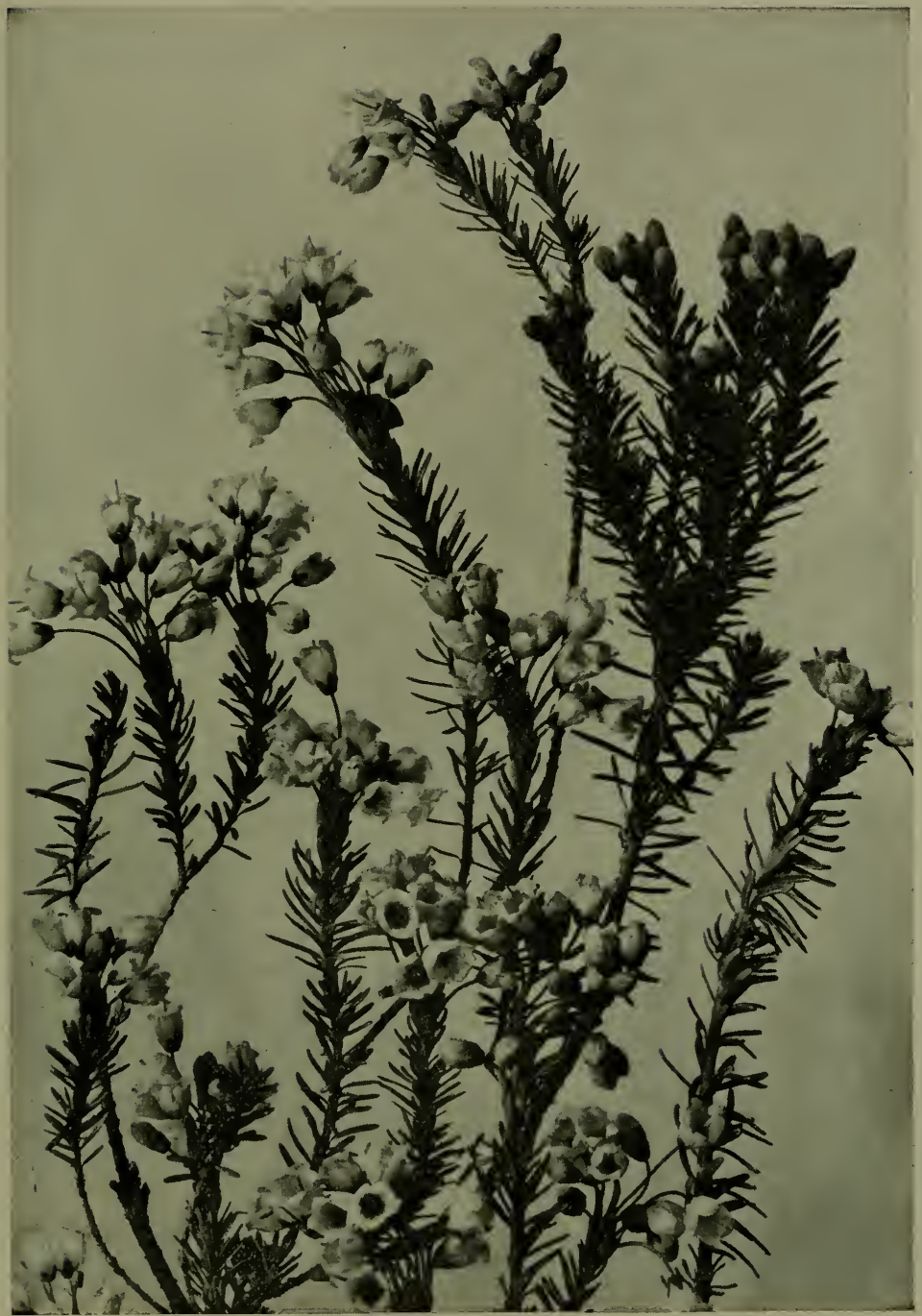

Red Mountain Heather

(Bryanthus empetriformis) 
tains, and at very high altitudes. It is a wonderful sight to see acre upon acre covered with its beautiful bells, until the slopes of the hills and the alpine meadows seem to be literally clothed with a glorious robe of rose-red Heather, whose border is embroidered with the White Mountain Heather and White Heath, the blue Speedwell and the yellow Arnica.

Many a traveller knows how true are the lines:

"When summer comes, the heather bell

Shall tempt thy feet to rove";

and many a man has echoed in his heart:

"Here's to the heath, the hill, and the heather, The bonnet, the plaidie, the kilt, and the feather;

Here's to the heroes that Scotland can boast, May their names never die - that's a Highlandman's toast!"

Truly a love for the Heath and the Heather is common to all nations, and is the especial trait of all mountain climbers.

Bryanthus intermedius, or Pink Mountain Heather, is a much rarer plant and is found in comparatively few localities. I first reported it from the Selkirk Mountains in I90I, though it had previously been reported from the Rockies by Macoun, Drummond, and Dawson.

It is easily known to travellers by means of its lovely pale pink bells. The foliage is precisely similar to that of $B$. empetriformis, but the flower differs in a few very minor particulars. This plant is probably a hybrid.

\section{RED BEARBERRY}

Arctostaphylos Uva-ursi. Heath Family

Diffusely much branched, and rooting at the nodes. Leaves: oblongspatulate, obtuse, tapering into a short petiole. Flowers: few, in short 


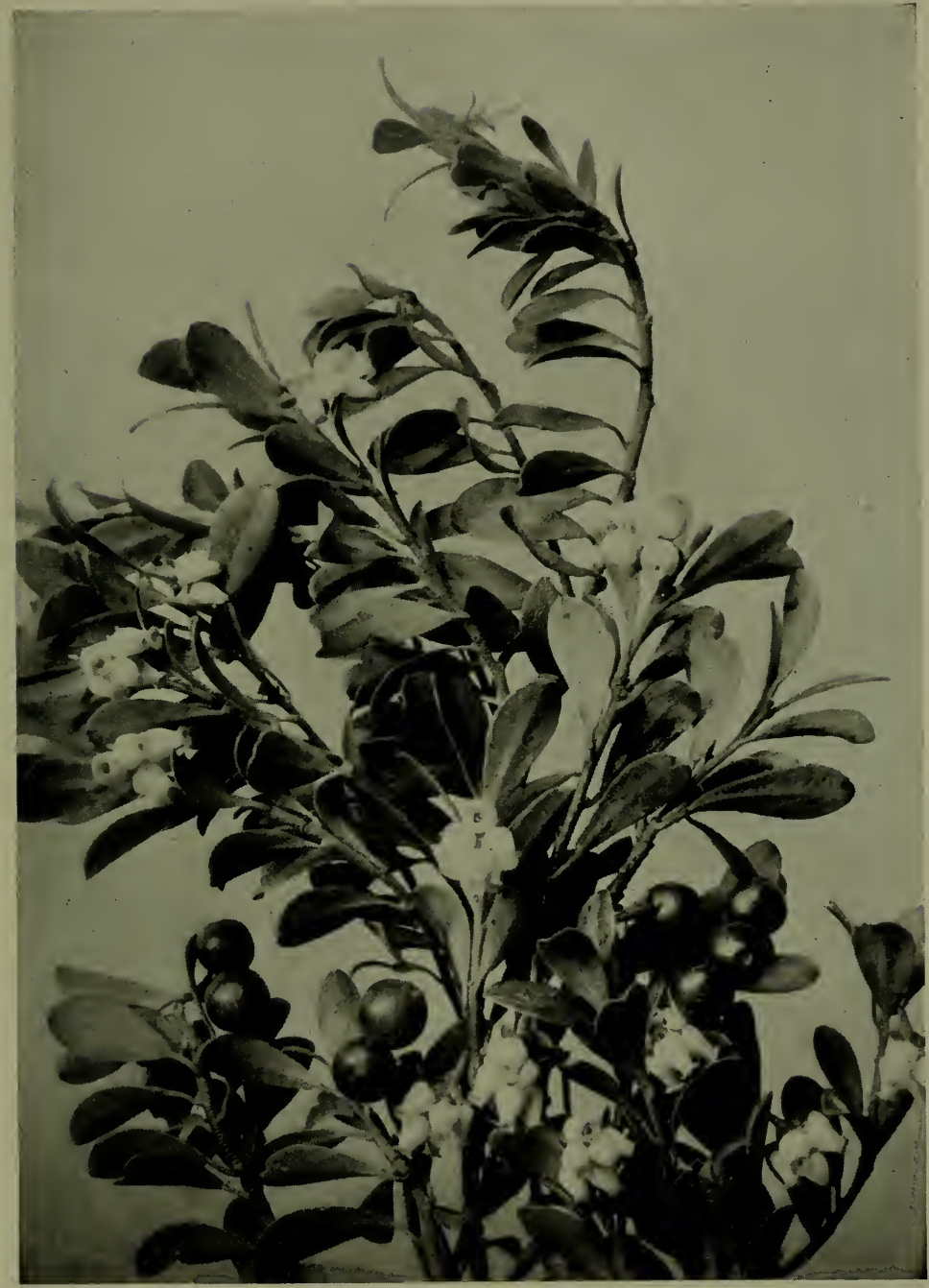

RED BEARBERry

(Arctostaphylos Uva-ursi) 
racemes; corolla ovoid, constricted at the throat. Fruit: globose, drupe red, glabrous, containing five coalescent nutlets.

A trailing shrub which is exceedingly handsome; it grows in depressed patches several feet in diameter, from a single main root. It is usually found creeping over dry gravelly places, and covering the rocks with its bright little evergreen leaves. In the autumn these leaves turn bronze, and lovely scarlet, dry, berry-like fruits gem the spreading branches.

White flushed with rose colour are these tiny rounded flowers, constricted at the throat, and giving forth a faint sweet odour.

"Oh! to be friends with the lichens, the low, creeping vines and the mosses,

There close to lie;

Gazing aloft at each pine-plume that airily, playfully tosses

'Neath the blue sky."

Doubtless the name Bearberry is derived from the fact that Bruin is very fond of the fruit of the Arctostaphylos, though with small game birds, and especially grouse, it is also a favourite article of food. This is the true Kinnikinic of the Indians who prize it for its astringent properties, using it as a medicine and also in the "curing" of animal skins.

Arctostaphylos alpina, or Alpine Bearberry, is a very tiny species, from two to four inches long, and is found growing on mountain summits as high as 7000 feet. It is usually prostrate, with thin' conspicuously veined leaves, a few pale pink or white flowers, and bright red juicy berries. This is also a shrub and in spite of its small size has shreddy bark.

Arctostaphylos tomentosa, or Manzanita, is tomentose 
and setose-hispid throughout. The densely-woolly leaves are oblong and tipped with a sharp point, and the bracts are leaflike. The flowers grow in short clustered racemes.

\section{OVAL-LEAVED BLUEBERRY}

Vaccinium ovalifolium. Huckleberry Family

Leaves: alternate, oval, short-petioled, glabrous on both sides, rounded at both ends or somewhat narrowed at the base, thin, entire. Flowers: white and pink, commonly solitary in the axils on rather short recurved pedicels; calyx-limb slightly toothed; corolla globose-ovoid, toothed; stamens ten. Fruit: a many seeded blue berry with a bloom, acid.

There are in the mountain regions many species of $V a c$ cinium that bear edible berries, but the Oval-leaved Blueberry and the Black Blueberry are the most conspicuous in fruit, the former having blue berries covered with a rich soft bloom and possessing an acid though not unpalatable flavour, and the latter having purplish-black berries that are quite sweet and pleasant to the taste.

The Oval-leaved Blueberry is a branching shrub, growing from three to ten feet high, and las smooth twigs that are sharply angled at the joints. The leaves are oval, green above and covered with a whitish bloom beneath. The small pink and white flowers are formed like tiny toothed bells, and grow singly at the ends of the slender recurved stalks, which causes them to droop downwards. The berries also are pendent.

Vaccinium mombranaceum, or Black Blueberry, is not so tall as the preceding species, seldom attaining a height of six feet. The leaves are larger than those of the Ovalleaved Blueberry, and are green on both sides and finely edged with very tiny teeth. The flowers are globular, and from their rounded corollas the long style protrudes. The 
recurved axillary stalks, which bear the blossoms, become upright in fruit and thus hold erect the large, sweet, purpleblack berries, which have no bloom.

Vaccinium ccespitosum, or Dwarf Bilberry, grows only from three to seven inches high, and has many little fine branches thickly covered with leaves, which are obovate, blunt, thickly serrulate and bright green on both sides. The stem-branches bear numerous tiny, bell-shaped, pinkish or white flowers, with the calyx five-toothed and about ten stamens. These in time turn to sweet blue berries, covered with a rich bloom, and so large as to be out of all proportion to the plant.

V accinium Vitis-Idca, or Mountain Bilberry, has crowded oval emarginate leaves. The most remarkable feature of this low, creeping, evergreen shrub is that it has numerous black bristly dots beneath the leaves. The clusters of tiny, waxen, pink bells grow on erect branches, which spring from the creeping stems and attain to a height of about eight inches. The berries are dark red and very acid.

Vaccinium erythrococcum, or Alpine Bilberry, has erect stems with numerous slender strict branches and branchlets. The leaves are ovate or oval and a lovely bright green, while the pink five-lobed flowers are solitary in the axils of the leaves. The berries are small and bright red. Vaccinium is the name by which classical writers have referred to some plant whose identity is lost to us, and even when it was given to the present genus of this name there is reason to believe that it was originally spelt Baccinium, meaning a plant which produces berries. Bilberry was no doubt formerly Bellberry or Hillberry, just as Blaeberry is only the Scottish pronunciation of Blueberry.

Vaccinium Oxycoccus, or Small Cranberry, is a creeping 
shrub, with alternate ovate entire leaves that are dark green above and white beneath and have revolute margins. It is very delicately formed and resembles a slender trailing vine far more than a shrub, which latter word we are accustomed by common usage to apply only to tall, stout, or bushy plants. The four or five tiny, narrow, pink divisions of the nodding corolla are spread wide open and reveal the anthers converging into a cone, which is extremely prominent when the flower is expanded. The fruit is a round red juicy acid many-seeded berry. This Cranberry grows chiefly in marshy places and swamps, also along the margins of lakes and pools.

\section{BIRD'S EYE PRIMROSE}

Primula farinosa. Primrose Family

Leaves: oblong, obtuse at the apex, narrowed at the base, tapering into petioles, the margins crenulate. Flowers: umbellate; bracts of the involucre acute; calyx-lobes acute, often mealy ; corolla salver-form, fivecleft; stamens five included filaments; anthers very short, oblong, obtuse.

A tall species of Primrose, with pink, lilac, or very occasionally white flowers, which grow in a cluster at the top of the long stalks and are salver-shaped; that is to say, the divisions of the corolla spread out flat at the top of the tube and disclose a yellow eye with five stamens forming a dark "pupil" in the centre of it. Hence the name of Bird's Eye. The leaves are long-shaped, being usually mealy white beneath, as denoted in the term farinosa, and all grow in a tuft at the base of the plant, surrounding the long bare flower-stalk, on the top of which a few small bracts will be found just below the blossoms.

Primula Maccalliana, or Dwarf Canada Primrose, is similar to the preceding species, but much smaller, growing only to an average height of four inches, whereas $P$. farinosa is 
usually about ten inches tall. The tiny leaves are all set in a tuft close to the ground, and are rarely mealy underneath; while the flowers are pale mauvish-pink in colour. Both these Primroses grow in very wet places. The generic name, Primula, refers to their early season of blossoming, for, as the poet says:

"Primroses, the spring may love them,

Summer knows but little of them."

\section{SHOOTING STAR}

Dodecatheon pauciflorum. Primrose Family

Stems: scape glabrous. Leaves: lanceolate, entire. Flowers: segments of the corolla rich purple-pink, the undivided part yellow, with a scalloped ring of deep purple midway between the base of the segments and the stamen-tube; stamen-tube yellow; anthers purple.

From two to eight of these quaint purple-pink flowers, each one on its own individual tiny stem, grow at the ends of the stout main stalks of the plant. Several of these stalks grow up from every root. With their reflexed petals resembling those of the Cyclamen (which also belongs to the Primrose Family), and their queer little pointed noses, the Shooting Stars are rather remarkablelooking flowers. They remind one of some bright-winged butterfly poised on the apex of a scape. The leaves all grow in a cluster at the foot of the plant and are longshaped and tapering towards the base. Very occasionally the flowers are white. The scientific name is derived from the Greek dodeka, "twelve," and theos, "god," thus signifying "twelve gods." Its application is not very clear, though Linnæus imagined he saw in its umbels of bright crowned flowers a little congress of divinities, and hence named it for an Olympian gathering of the gods. 


\section{SPREADING DOGBANE}

Apocynum androscmifolium. Dogbane Family

Stems: one to three feet high, branches broadly spreading, smooth. Leaves: ovate or oval, opposite, entire, smooth above, usually hairy beneath. Flowers: open-campanulate, five-parted, lobes revolute. Fruit: slender elongated terete seed pods, usually in pairs.

A plant with quantities of little spreading branches bearing oval spine-tipped leaves and numerous pink flowers, veined with a deeper red, in loose terminal and axillary convex clusters. The plant is full of a milky juice.

\section{ALPINE PHLOX}

Phlox Douglasii. Polemonium Family

Stems: rather slender, ascending or erect. Leaves: acerose to linearsubulate, pubescent to nearly glabrous, often ciliate near the base, loosely imbricated. Flowers: sessile or short-peduncled. Fruit: capsule ovoid, three valved.

The plants of the Alpine Phlox form cushion-like tufts on the rocky slopes of the mountains, where their pretty little pink, lilac or white flowers, that terminate the branchlets, are usually sessile. The corolla is salver-form with a five-lobed border, and there are five stamens on its tube. The leaves are needle-like, rigid, loosely imbricated, and often clustered at the nodes.

\section{SCARLET GILIA}

Gilia aggregata. Polemonium Family

Stems: erect, leafy, simple or sometimes loosely branched. Leaves: pinnately parted into narrowly linear segments, mucronulate. Flowers: calyx glandular, tube campanulate, as long as the subulate teeth, corolla tubular-funnelform, the lobes ovate or lanceolate, acuminate. Fruit: seeds developing mucilage and spiral threads when wetted, 
The scarlet flowers of this plant are spotted with white, and grow in a narrow, loose, cylindrical panicle, they are sessile in small short-stalked clusters, and the tubularfunneliform corolla has ovate, pointed lobes that are widely spreading and soon recurved. The stamens are inserted in the throat or below the sinuses of the corolla. The thickish leaves of this tall biennial Gilia are compound and mostly petioled, being pinnately parted into narrow, pointed segments. The seeds develop mucilage and spiral threads when wetted. The plant has a very disagreeable smell.

\section{WILD BERGAMOT}

\section{Monarda fistulosa. Mint Family}

Stems: branched, rough-hairy. Leaves: ovate-lanceolate, serrate, pubescent, especially beneath. Flowers: calyx slightly curved, very hairy in the throat, corolla elongated, two lipped, lips linear, somewhat equal, the upper erect, entire or slightly notched, the lower spreading, three lobed at the apex, its lateral lobes ovate, obtuse, the middle one narrowed and slightly notched.

The Wild Bergamot is an aromatic plant with thin, ovatelanceolate, pointed leaves, toothed at the edges and rounded at the base. The dense flower clusters which are magenta, purplish, lavender, whitish or yellow, are all terminal and solitary, and have often purplish bracts that are quite conspicuous. The tubular calyx is erect, and hairy in the throat, and the two lipped corolla has two protruding anther-bearing stamens. A few flowers only open at a time, which leaves much of the rounded heads of the hairy calyces exposed.

\section{RED MONKEY FLOWER}

\section{Mimulus Lewisii. Figwort Family}

Stems: numerous, pubescent, viscid. Leaves: oblong-ovate to lanceolate, denticulate, acute. Flowers: peduncles longer than the leaves; 
PLATE XLIX

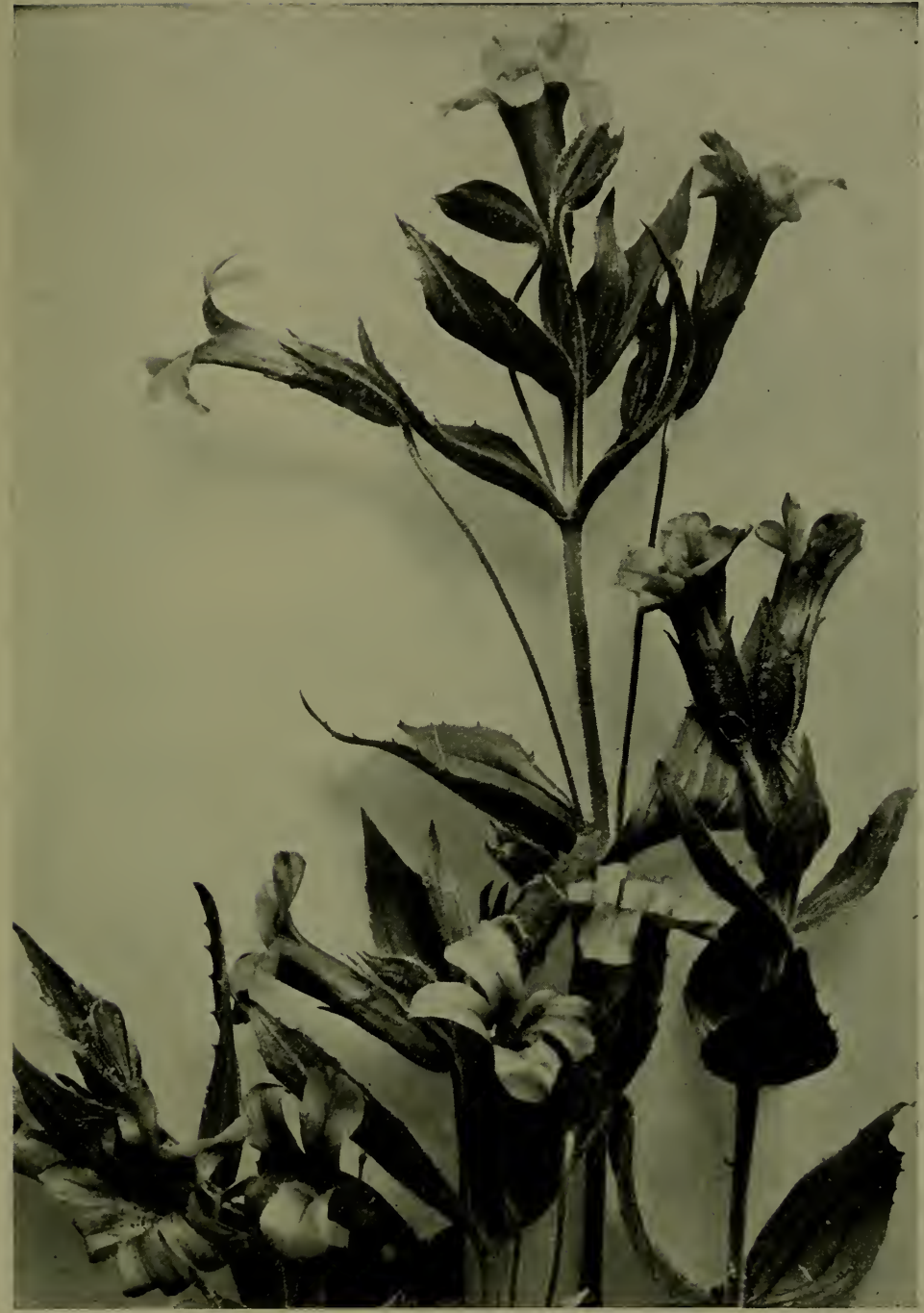

Red Monkey Flower

(Mimulus Lewisii) 
calyx long, campanulate, its triangular teeth very acute; corolla with broad throat and bilabiate limb, lobes of the upper lip obcordate, of the lower lip obovate.

A tall handsome plant, with ample foliage. The leaves are sharply toothed at the edges and very pointed at the apex; they grow in pairs, clasping the stem, and from their axils spring the slender flower-stalks bearing brilliant magenta blossoms. Each of these blossoms has a long green calyx, from out of which comes the richly coloured tube, that spreads open into two lips, the upper one being reflexed and two-lobed and the lower one spreading and three-lobed. The throat has two yellow patches inside and is covered with white hairs; indeed, the whole plant is extremely hairy and sticky, and has a sweet sickly smell.

The favourite haunt of the Red Monkey Flower is some damp hollow, either in marshy ground or on the banks of an alpine stream. Though never actually growing in the water, it may frequently be found flourishing luxuriantly on those little islands so common in the midst of mountain rivers, where, sheltered by other large moisture-loving herbs, it attains a height of from one to two feet.

Mimulus is the diminutive of the Latin mimus, meaning " a mimic actor," and alludes to the laughing face of the flower, which appears to shoot out its ripe red lips in mockery at the traveller as he passes by, opening its mouth in a droll grimace that displays its yellow throat. Hence also the common name Monkey Flower, given in allusion to the ape-like pertness of the plant's appearance. Thus man has set a "cap and bells" upon the Mimulus and appointed it buffoon to the Court of Nature. 


\section{RED INDIAN PAINT BRUSH}

\section{Castilleja miniata. Figwort Family}

Stems: numerous and tufted on a short rootstock, mostly simple and strict. Leaves: lanceolate or ovate-lanceolate, acute, entire. Flowers: spikes short and dense; corolla long; galea exserted, longer than the tube, the short lower lip protuberant and callous with short, ovate, involute teeth.

This flower, though actually of a pale greenish-yellow colour, is almost entirely enfolded in a long, tubular, greenish calyx, so that it is chiefly conspicuous by reason of its large gorgeously coloured bracts of pink, rose, scarlet, crimson, or orange (and sometimes white), and therefore I have placed it in the Pink to Red Section, for it is here that most people will look for it, as only botanists are ever likely to guess that it is not in reality a gaudy flower.

The Red Indian Paint Brush is the only alpine wild flower which really rivals the scarlet geranium of our cultivated gardens, and no grander sight may be seen by travellers than where from " tree-line," close to the edge of the eternal snows, down into the deep green heart of the valleys, the slopes and steeps are clothed with a marvellous mantle of vermilion and golden Castillejas. As the sunlight flames across these royal-robed hills every blossom blooms and burns with effulgent glory, until

"Earth's crammed with Heaven, And every common bush afire with God."

No words can describe the brilliant beauty of such a scene, far from uncommon at the higher altitudes, where many species of Castilleja thrive abundantly, and you may walk for miles across meadows and banks whereon the Paint Brushes and Painted Cups (or Flame-flowers, as they 
are sometimes called) run riot in magnificent profusion. Every colour, every shade from coral pink to cardinal, from canary tint to tangerine, is growing and blowing on either hand, with here and there a single snowy spike to emphasize the splendid conflagration of colour.

It is wonderful to note that all this carmine and gold is not lavished on the corolla of the flower, but chiefly on the bracts, which are set below each insignificant blossom, from whose cleft tube the long pistil protrudes. The plant grows from six inches to two feet high and the leaves are pointed and have even margins.

The Castillejas are parasitic on the roots of other plants; that is to say, they sometimes fasten their roots upon those of their neighbours and thus prey upon juices already partially assimilated. They have not, however, as yet become hardened thieves; if they had, they would have lost their leaves and green colouring matter (chlorophyll), for every plant that turns pirate is punished by Nature, and branded for all the world to see, by being gradually deprived of its foliage and its honest hue. But the Castilleja is only guilty of petty larceny, being but a partial parasite, and so far it is the botanist, and not Nature, who has denounced its backsliding.

Castilleja pallida, or White Indian Paint Brush, much resembles the preceding species, but its flowers and bracts are always greenish-white, cream colour, or palest yellow. It is a small, short plant, with slender stems and tiny narrow leaves, and it only grows at very high altitudes.

Though this species properly belongs in the White to Green Section, it is placed here for greater convenience.

Castilleja purpurascens, or Purple Indian Paint Brush, is more or less dark purplish-red throughout, and has narrow 
clasping leaves with smooth eren edges. The inflorescence is hairy, the bracts being rarely cleft and usually of a deep crimson hue or sometimes red to rose-colour, while the flowers are greenish-yellow with red margins. This plant is found in abundance in the lower valleys.

Castille ja lancifolia, or Lance-leaved Indian Paint Brush, has numerous long narrow leaves terminating in sharp points. These leaves are rather stiff and three-veined. The flowers have a crimson calyx with a green base, a yellowish-green corolla and bright red bracts.

Castillcja angustifolia var. Bradburii, or Bradbury's Painted Cup, may be recognized by its leaves, which are large and cleft above the middle into three or five unequal lobes, the centre one being oblong and rounded at the apex, and the lateral ones narrower.

"Flowers that with one scarlet gleam

Cover a hundred leagues, and seem

To set the hills on fire."

Thoreau speaks thus of the prairie species:

"The Painted Cup is in its prime. It reddens the meadow,- Painted Cup meadow. It is a splendid show of brilliant scarlet, the colour of the Cardinal Flowers, and surpassing it in mass and profusion. I do not like the name. It does not remind me of a cup, rather of a flame when it first appears. It might be called Flame Flower, or Scarlettip. Here is a large meadow full of it, and yet very few in the town have ever seen it. It is startling to see a leaf thus brilliantly painted, as if its tip were dipped into some scarlet tincture surpassing most flowers in intensity of colour."

These words are equally applicable to the mountain Castillejas. Truly the glorious flower-spikes of the Paint Brushes and Painted Cups are like tongues of flame that run burning through the herbage of the hillsides. 


\section{"Scarlet tufts}

Are glowing in the green like flakes of fire."

And when we see them in their royal radiance we remember how the ancients once worshipped the God of Fire and understand.

Castilleja rupicola, or Bright Painted Cup, is a hairy plant with tufted stems growing from a multicipital caudex. The herbage is often purplish and the leaves are narrow deeply cleft into three to seven lobes, while the broad-lobed bracts are tinged with bright scarlet and the flowers, growing in a short raceme, are of the same vivid hue.

Castilleja oreopala, or Magenta Painted Cup, has erect stems which are somewhat furrowed by the inconspicuous decurrence of the narrow sessile leaves that have one or two pairs of spreading lobes. The bracts are three-cleft to the middle and their lobes, as well as the calyx, are usually a rich magenta or rose-purple hue, rarely crimson or white. This plant grows at very high altitudes.

\section{WESTERN WOOD BETONY}

\section{Pedicularis bracteosa. Figwort Family}

Stems: stout, high, erect, simple. Leaves: linear in outline, the radical ones petioled, pinnate, the oblong leaflets pinnately parted, the segments incisely dentate, cauline broader in outline; bracts ovate, shorter than the flowers. Flowers: spike cylindrical, very dense; calyx sparsely pilose; corolla ochroleucous, the tube equalling the calyx ; galea longer and larger than the lower lip, its cucullate summit slightly produced at the entire endentulate orifice, but not beaked.

A tall coarse plant, with handsome, green, fern-like foliage, but clumsy uninteresting flowers. On the top of the stout reddish stems grow large, hairy, bracted spikes, with many small dull red flowers, which resemble a parrot's beak, with their raised hooded upper lips and small lower ones. 
These flowers are subtended by. conspicuous bracts, hence the name bracteosa.

The Romans had a proverb, "Sell your coat and buy Betony," and another old saying was, "May you have more virtues than Betony." Antoninus Musa, physician to the Emperor Augustus, wrote in high praise of its powers, stating that it would cure forty-seven of the ills to which human flesh is heir.

Franzins, in his History of Brutes, alludes to its healing virtues for animals. He says of the stag, "When he is wounded with a dart, the only cure he hath is to eate some of the herbe called Betony, which helpeth both to draw out the dart and to heale the wound."

Sir William Hooker is our authority for saying that the common name is a corruption of Bentonic, ben meaning " head," and ton " good " or " tonic."

Pcdicularis gronlandica, or Elephant's Head, is so-called from the close resemblance of its blossoms to a miniature elephant's head, the flat forehead, long drooping ears and curving trunk being all perfectly outlined.

This Pedicularis has slender, rather brittle, red stalks, which are clothed with many small, fern-like, reddish leaves, and a group of tall fringed foliage grows up about it from the ground. It is a tall plant, often attaining a height of eighteen inches, and its terminal spikes are long and densely flowered with tiny dull red blossoms, which have a toothed calyx that is nearly as long as the tooth of the corolla. The corolla is two-lipped, the upper lip, or galea, being concave and having a long thread-like beak, while the lowèr one is three-lobed. 


\section{SMOOTH-LEAVED HONEYSUCKLE}

Lonicera glaucescens. Honeysuckle Family

Twining, the branches glabrous. Leaves: chartaceous-margined, not ciliate, only the upper pair connate-perfoliate. Flowers: verticillate in a short, terminal, interrupted spike; corolla yellow changing to red, the tube strongly gibbous at the base, the two-lipped limb shorter than the tube; stamens and style exserted.

A climbing vine, with pairs of smooth leaves covered with a delicate bloom, growing along its branches, only the upper ones joined together round the stem, which bears at its apex a cluster of red and gold flowers. These blossoms are trumpet-shaped, and the five stamens and style project beyond the corolla, which is vermilion outside and yellow within. The berry is soft and juicy. Sometimes this vine is called Woodbine, and Shakespeare in his exquisite romance of $A$ Midsummer Night's Dream refers to this fact when he makes Queen Titania say to Bottom the Weaver, with whom the Fairy King Oberon has caused her by means of a love philter to fall in love:

"Sleep thou, and I will wind thee in my arms. So doth the woodbine the sweet honeysuckle Gently entwist."

Milton in Lycidas speaks of "the well-attir'd woodbine," and truly, for no "gadding vine" was ever graced with finer or more fragrant flowers.

Spenser calls it by the older name of Caprifole, or Goatleaf, because, like the mountain goat, it climbs over almost inaccessible crags; the French and Italian names are also similar, being respectively Chève-fenille and Caprifoglio. 


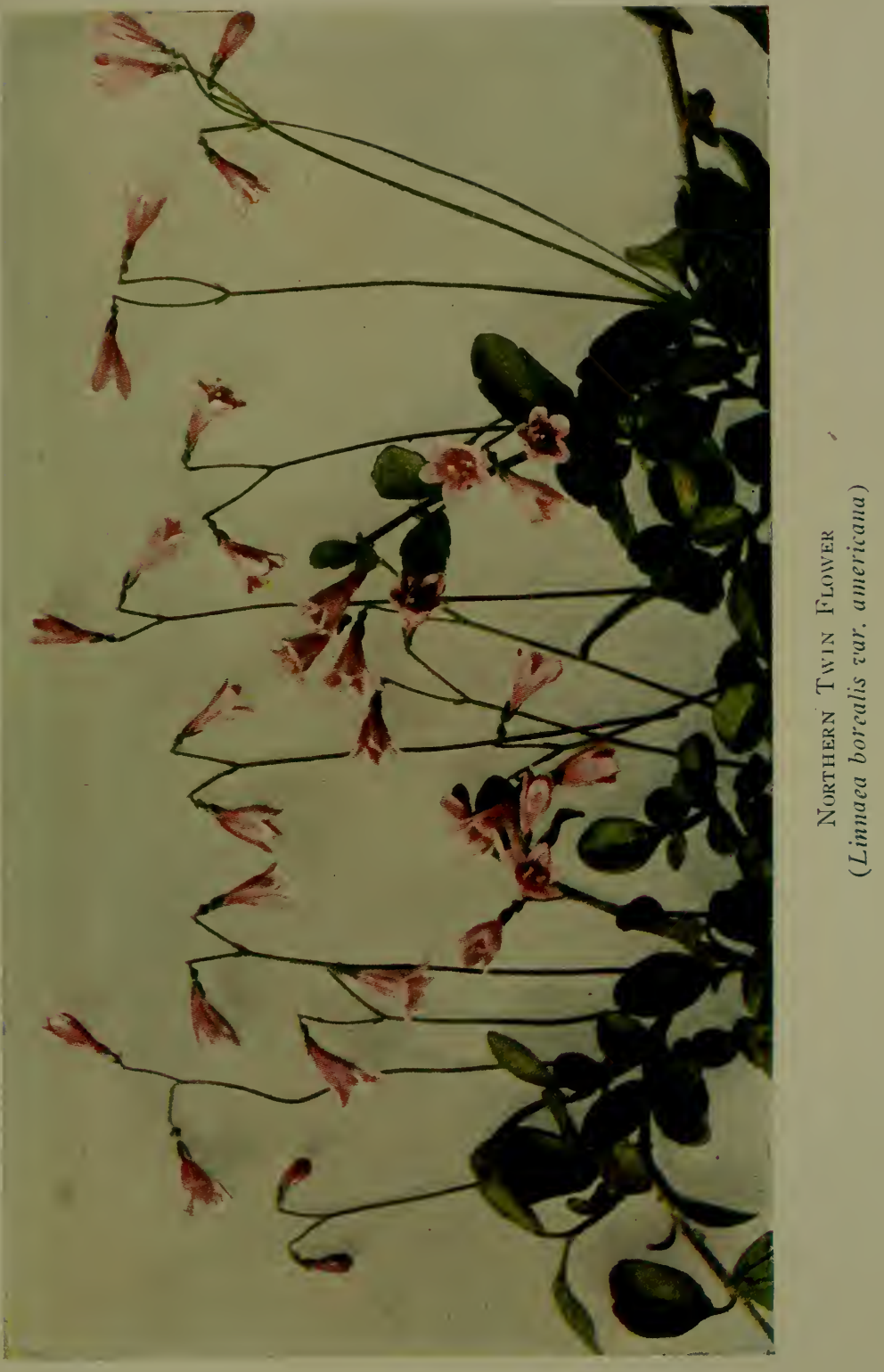





\section{NORTHERN TWIN FLOWER}

Linnaa borcalis var. americana. Honeysuckle Family

Branches slender, trailing. Leaves: obscurely crenate, thick, sometimes wider than long. Flowers: two-flowered, nodding; peduncles slender, erect, two-bracted at the summit; calyx-tube five-lobed; corolla tubular-campanulate, five-lobed.

This lovely fragrant plant, called after the great Linnæus, the Father of Botany, is a

\section{"Monument of the Man of Flowers,"}

who loved its exquisite pink bells above all else in Nature, and who sealed his preference by adopting it as his crest.

There is no more charming spot in the mountains than some sequestered nook or shady bank carpeted and adorned by the delicate trailing branches of the Northern Twin Flower, its glossy green leaves mingling with the moss, and its pale pink pairs of bells, veined and lined with rose colour, growing in lavish profusion and "gently to the passing breeze diffusing fragrance." The slender stalks of this vine stand 'up erect, and, forking near the summit, bear on either side twin-born pendent blossoms of rare loveliness.

Seeking the shade and moisture, this plant avoids exposed or sunny places, for

"Beneath dim aisles, in odorous beds, The slight Linnæa hangs its twin-born heads,"

and reminds us as we gather its graceful perfumed bells that "sweetest of all things is wild-flower air."

It is widely distributed throughout most northern countries, and is found even within the limits of the Arctic Circle, 


\section{CANADA HELIOTROPE}

\section{Valeriana Scouleri. Valerian Family}

Stems: stout. Leaves: the basal on long petioles, oblong, threelobed, tapering to both ends, the lateral lanceolate; stem leaves two to four pairs, pinnately parted in five to seven segments, lanceolate, acute, entire or undulate. Flowers: corolla long, funnel-form, stamens and style exserted.

A smooth plant with oblong three-lobed basal leaves growing on long stalks, the centre lobe being very much the largest of the three. The stem leaves are pinnately parted, narrow and pointed, and have entire or rarely undulated margins, while the pink flowers grow in a flat cymose panicle and have a funnel-form corolla. The roots have a most disagreeable and very strong odour.

\section{ROUGH FLEABANE}

\section{Erigeron glabellus. Composite Family}

Perennial by a woody root. Stems: simple or branched above, sometimes hirsute. Leaves: pubescent, entire, the basal ones spatulate; stem-leaves oblong-lanceolate, obtuse or acute. Flowers: heads several or solitary, involucre hemispheric, hirsute; rays very narrow, about one hundred or more.

This charming Fleabane grows in dry soil and bears flowers of many hues, - pink, mauve, cream, and white. It has long narrow leaves, which, together with the stalks, are hairy.

\section{PINK EVERLASTING}

Antennaria rosea. Composite Fanily

Floccose-woolly, surculose, forming broad patches. Leaves: basal ones spatulate or obovate, white-canescent on both sides: stem-leaves linear, sessile. Flowers: heads in a terminal capitate or corymbose clușter. 
PLATE L

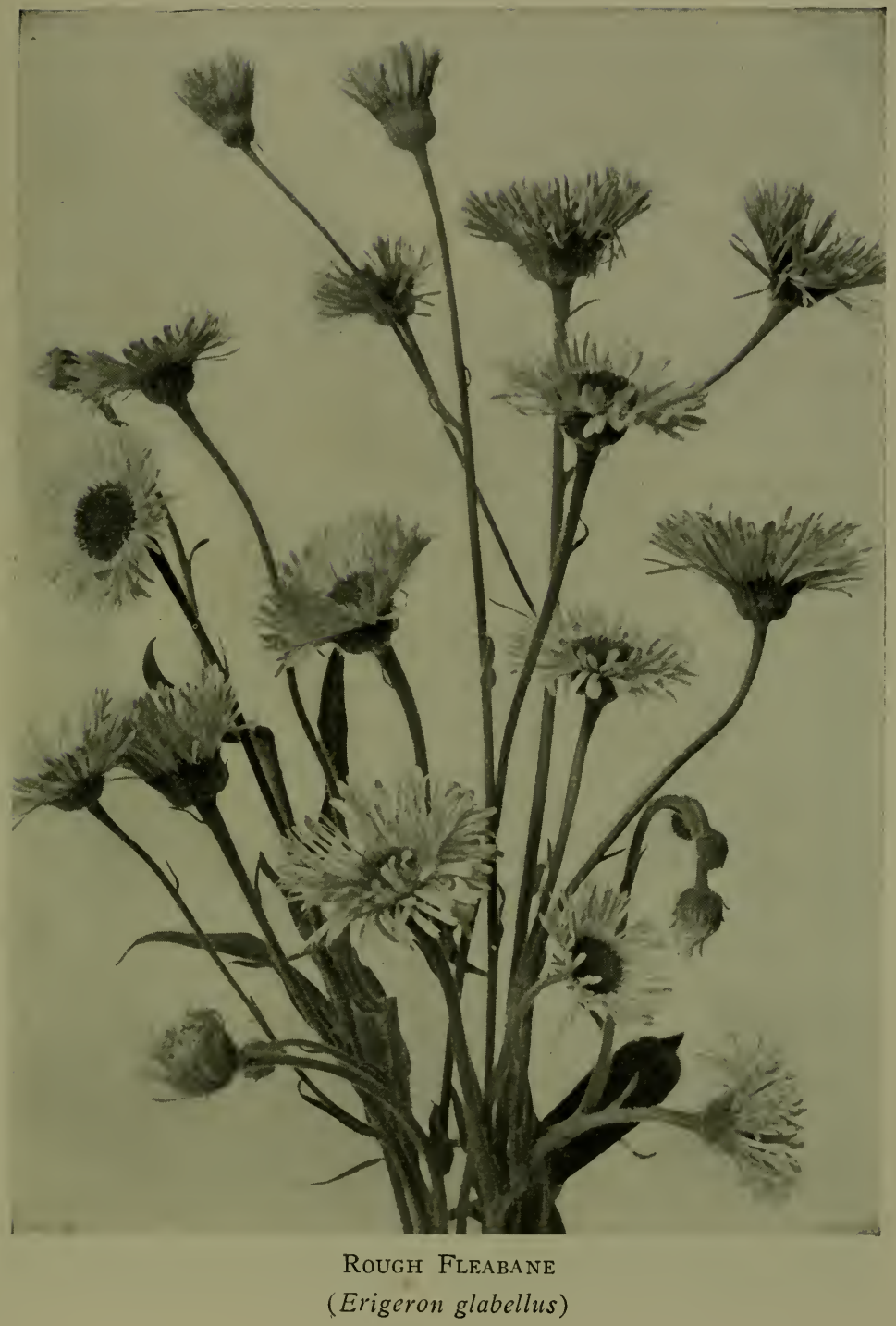




\section{PLATE LI}

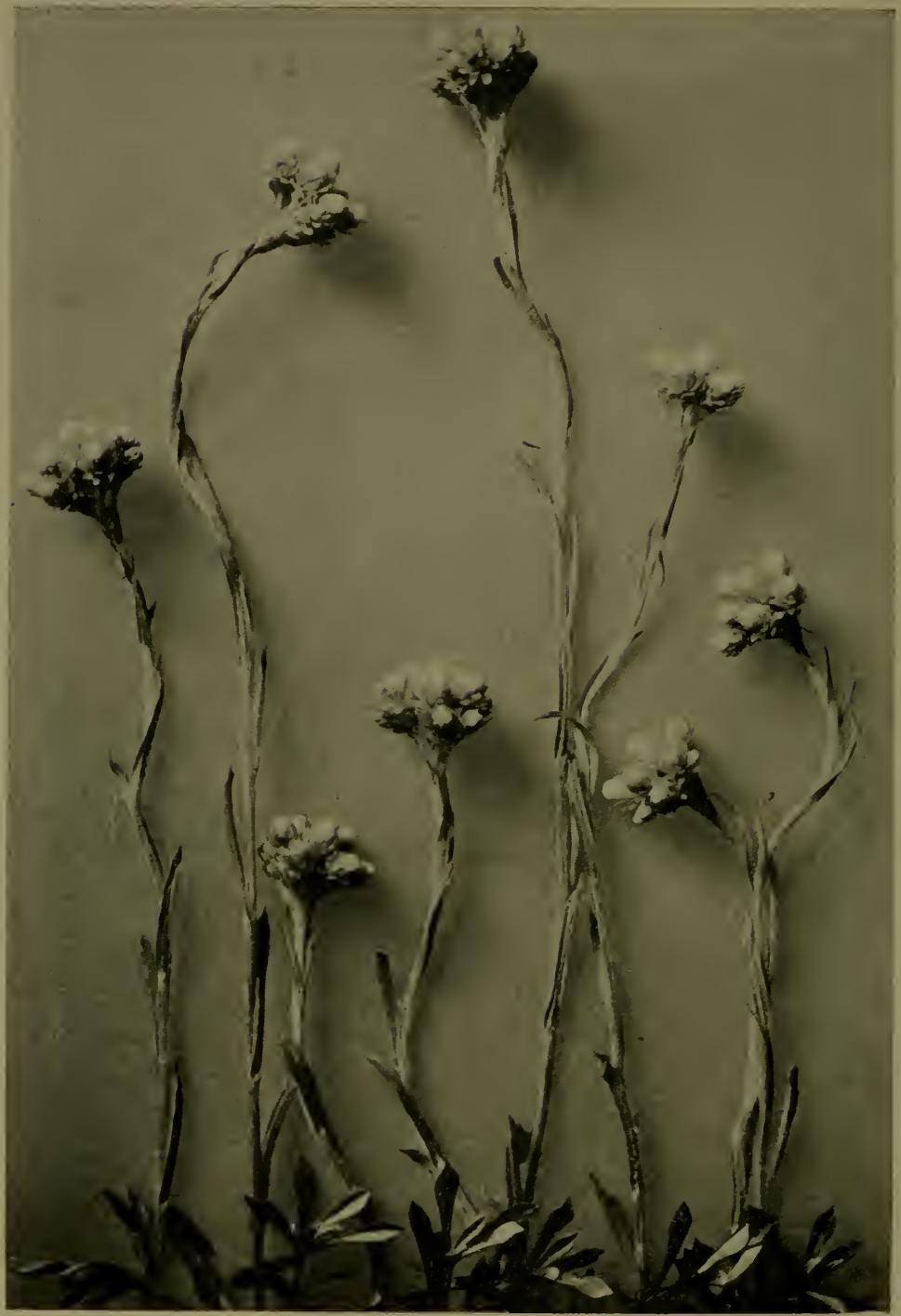

Pink Everlasting

(Antennaria rosca) 
The Pink Everlasting is so conspicuous by reason of its rosy crackling flowers, with their white silky centres and white woolly stems and leaves, that it requires little definite description for identification. It has a tuft of procumbent foliage at the base, and all the way up the stem there cling many tiny narrow leaves. Growing from two to twelve inches high, this plant will be found in the same localities as the white species. 



\title{
WILD FLOWERS OF THE NORTH AMERICAN MOUNTAINS
}

\author{
SECTION VI \\ BLUE TO PURPLE FLOWERS
}





\section{SECTION VI \\ BLUE TO PURPLE FLOWERS}

\section{PURPLE GARLIC}

Allium Schonoprasum var. sibiricum. Lily Family

Bulbs narrowly ovoid, clustered. Stems: scape rather stout, bearing below the middle one or two elongated, linear, terete, hollow leaves; other leaves basal; bracts of the umbel two, broadly ovate. Flowers: in umbels, capitate; perianth of six equal, distinct, lanceolate, onenerved segments.

This handsome Purple Garlic with its large dense flowerheads and long hollow leaves is not at all common in the mountains, but is frequently cultivated in cottage-gardens for the sake of its beautifully coloured blossoms. Like all the Garlics, it has a very pungent odour.

\section{STIFF BLUE-EYED GRASS \\ Sisyrinchium angustifolium. Iris Family}

Stems: two-edged, slender, erect, rigid. Leaves: commonly all basal, linear, rigid, almost setaceous, bracts two, very unequal, erect, the lower one twice as long as the upper one. Flowers: six segments of the perianth spreading, aristulate.

"For the sun is no sooner risen with a burning heat, But it withered the grass, And the flower thereof falleth, And the grace of the fashion of it perisheth."

Was it of this tiny yet brilliant purple-blue flower that the Apostle Saint James wrote the above verse? Did he espy it, as he walked abroad, nestling amongst the sedges 
that fringed the streams? It is a very fragile little blossom, and as it resents being picked to the extent of immediately shrivelling up and dying, travellers had better be content to admire it where it flourishes in the moist lowlying meadows, and refrain from all attempts to gather it. This "little sister of the stately blue Flag" only blooms for a single day, and each morning new buds open to replace the fallen petals of yesterday. Its flowers consist of six translucent purplish-blue segments, veined with a darker hue and tipped by a bristle from a notch. These grow on thread-like stalks between two very long narrow bracts, the lower one of which is usually twice as long as the upper one. In the centre of each blossom is a small patch of yellow, and the style, which is long and protruding, is tipped by a conspicuous three-cleft stigma.

The name Blue-eyed Grass is most appropriate to this plant, for its leaves are certainly quite grass-like, being long and slender, and nearly all spring up from the densely tufted base, together with the stems, which latter are flattened on both sides. The flowers are very like soft purplish-blue eyes with their dilated yellow " pupils," as they

"Gently gaze toward the sky, Answering the azure blue on high."

Another poet sings thus of the Blue-eyed Grass:

"Blue-eyed grass in the meadow, And yarrow blooms on the hill, Cat-tails that rustle and whisper, And winds that are never still;

"Blue-eyed grass in the meadow,

A linnet's nest near by, Blackbirds carolling clearly

Somewhere between earth and sky. 


\section{"Blue-eyed grass in the meadow, And the laden bee's low hum, Milkweeds all by the roadside, To tell us summer is come."}

Sisyrinchium idahoense, or Twisted Blue-eyed Grass, has erect stems which are usually twisted. The leaves are thin and somewhat lax and the spathes are often deflexed long and narrow, the outer one longer than the inner one. The flowers grow on erect stalks and are deep violet-blue with a small yellow eye. The capsule is globose.

Sisyrinchium septentrionale, or Small Blue-eyed Grass, is a low plant growing in small tufts and the leaves are stiff erect and mostly setaceous. The rose-violet flowers are very small and arise from between the short, partly double, spathes and the closely-subtending slenderly prolonged outer bract. The segments of the perianth are acuminate and short-aristate, not retuse.

\section{PASQUE FLOWER}

Anemone patens var. Wolfgangiana. Crowfoot Family

Stems: erect, villous with long silky hairs. Leaves: ternately divided, the lateral divisions two-parted, the middle one stalked and threeparted, the segments deeply cleft into linear acute lobes. Flowers: developed before the leaves; sepals five to seven; petals none. Fruit: achenes compressed, pointed, ending in long feathery tails.

The most remarkable feature of this large purple Anemone is that it blossoms before its foliage is developed. Frequently you will find lovely specimens of these flowers in full bloom, standing up very straight on their thick downy stalks, while the leaves, which are finely dissected, are still folded up in soft silkiness about the base of the plant. The five to seven sepals are pale purple outside, but almost white inside, and are extremely soft and silky, while 
below them on the stalk grows a circle of very hairy leaflets. Inside the floral cup are numerous yellow stamens clustered close together round the green carpels.

As time passes the stalks elongate, the purple flowers fall off, and the seeds are formed. Then the heads present a lovely plumose appearance, for to each seed is attached a long silky tail, the whole forming a pretty feathery tuft.

\section{PURPLE CLEMATIS}

Clematis columbiana. Crowfoot Family

A trailing and partly climbing vine. Leaves: trifoliolate; leaflets thin, ovate, acute, more or less cordate, slightly toothed or entire; petioles slender. Flowers: solitary; sepals thin and translucent, strongly veined, silky along the margins and the veins; petals spatulate; styles persistent, plumose throughout.

The large lovely flowers of the Purple Clematis are attractive by reason of their four or five big purple-blue sepals, for their petals are very small and inconspicuous, surrounding the numerous yellow stamens. When in fruit this plant is also interesting, as the fine feathery styles form silvery heads, the long plumes of which are delicately entwined.

Its slender leaf-stalks are the means by which the Clematis climbs and clings to bushes, trees, and rocks, festooning with graceful garlands everything that comes in its way and delighting the traveller's eye with its wide-spread, semi-transparent, prominently veined flowers. The leaves are formed of three small, deeply veined leaflets, which grow on slim, rather woody stems.

This plant is a constant ornament to the alpine woods during the summer months, for when its true flowering season is past the pretty green foliage and large tufts of feathery seeds still render it an object of admiration. 


\section{BLUE COLUMBINE}

Aquilegia brevistyla. Crowfoot Family

Stems: slender, erect, branching. Leaves: basal ones biternate, lobed and crenate; stem-leaves few, nearly sessile. Flowers: small, nodding, blue and white; spurs short.

The smallest of the mountain Columbines, it may easily be recognized by its mauvish-blue and creamy blossoms and its very short styles. It is a more compact and therefore less graceful flower than $A$. formosa or A. flaicscens.

The Columbine was first introduced into England from the Virginia Colony in the reign of Charles I, when a young botanist sent it as a gift to the great Tradescant, gardener and herbalist to the King.

\section{MOUNTAIN LARKSPUR}

\section{Delphinium Brownii. Crowfoot Family}

Stems: tall from a fascicle of thick roots. Leaves: numerous, mostly orbicular in outline, five-to-seven parted, the lower into cuneate and the upper into narrower-cleft and laciniate divisions, petioled. Flowers: racemes many-flowered on short erect pedicels.

The tall Mountain Larkspur is a very handsome plant. It is nearly always a rich purple hue, but very occasionally it bears white or pinkish-mauve blossoms. Standing from one to four feet high, these Dclphiniums (so called from their fancied resemblance to a dolphin) may be found in immense quantities in the high alpine meadows, their long flower racemes towering up above a mass of deeply cleft dark green foliage. Each flower grows on a tiny upright stalk attached to the main stem, and has four small whitish petals, the upper pair smooth and developed backwards, and enclosed in the spur of the calyx, and the two lower ones deeply notched and very hairy. The sepals are five in num- 
ber and of a lovely intense blue colour; the top one is prolonged at the back into a hollow spur, and the others are plain.

This plant is also called Monkshood, the reason wherefor may readily be seen.

Delphinium Mensiesii, or Blue Larkspur, is a smaller species growing only from six to eighteen inches high and having few leaves and fewer flowers on its hairy stems. Though usually

\section{"Blue as the heaven it gazes at,"}

this Larkspur has sometimes white blossoms marked with purple veins.

Delphinium bicolor, or Blue-veined Larkspur, is a small species which grows six to ten inches high from fasicled and deep descending roots. It is a stout, pubescent plant, with thickish leaves, the lower ones orbicular in outline, and all deeply cleft into narrow, obtuse segments. The flowers grow in scanty racemes, and have pale yellowish or whitish petals, which are conspicuously blue-veined. This species is found in dry places among the mountains.

\section{MOUNTAIN SAXIFRAGE}

\section{Saxifraga oppositifolia. Saxifrage Family}

Stems: prostrate, densely leafy. Leaves: sessile, ovate, nearly orbicular, persistent, keeled, fleshy, opposite or imbricated in four rows, the margins ciliate. Flowers: solitary, nearly sessile; calyx-lobes obtuse, much shorter than the oborate purple petals.

The simple description of Silene acaulis, or Moss Campion, given on page $2 \mathrm{I} \mathrm{I}$, is applicable in several particulars to this Mountain Saxifrage, which is also a dwarf arcticalpine flower and only grows at great altitudes. The chief difference between the two plants lies in the leaves, which 
in the Campion are extremely fine and narrow and in the Saxifrage are egg-shaped and thickish, with a strongly marked keel and hairy margins. The stems of the Saxifrage are prostrate and very leafy, and the flowers are purple and grow almost flat upon the ground.

It was John Keble who first drew our attention to the fact that they are

"The loveliest flowers that closest cling to earth."

It was also evidently to some such prostrate alpine plant as the Mountain Saxifrage that he referred when he wrote:

"Bloom on then in your shade, contented bloom,

Sweet flowers, nor deem yourselves to all unknown.

Heaven knows you, by whose gales and dews ye thrive;

They know, who one day for their altered doom

Shall thank you, taught by you to abase themselves and live."

\section{PURPLE CINQUEFOIL}

Potentilla palustris. Rose Family

Stems: stout, ascending from a decumbent rooting perennial base. Leaves: pinnate, oblong, serrate. Flowers: few in an open cyme. Fruit: achenes glabrous, hairy receptacle becoming large and spongy.

This Purple Cinquefoil is a marsh plant with a decumbent root and a somewhat woody base. The leaves are five to seven foliolate, the lower ones long-stalked and the upper ones nearly sessile, the leaflets being oblong, toothed, blunt at the apex and narrowed at the base. The showy flowers, which grow in an open cyme, have a large calyx which is dark purple within and much exceeds the small purple petals. The numerous stamens are inserted on the pubescent receptacle which becomes spongy in fruit. 


\section{ALPINE LUPIN}

Lupinus subalpinus. Pulse Family

Stems: simple, leafy. Leaves: palmately divided, leaflets spatulateoblanceolate, obtuse, villous beneath, glabrous above. Flowers: in a terminal raceme, keel glabrous. Fruit: pod linear-oblong, obliquely pointed, seven to nine seeded.

The showy blue blossoms of the Alpine Lupin, which are found at high altitudes, grow in many-flowered terminal racemes borne on a stoutish stalk. The individual flowerstalks are slender, the leaflets are broad at the base and somewhat rounded at the top.

\section{ASCENDING MILK VETCH}

Astragalus adsurgens. Pea Family

Stems: rather stout, ascending or decumbent. Leaves: odd-pinnate; leaflets oval to linear-oblong, obtuse, fifteen to twenty-five, peduncles exceeding the leaves. Flowers: erect, in short dense spikes; tube of the calyx long-campanulate, twice as long as the setaceous teeth, subvillous with partly black hairs; petals clawed; standard erect, ovate; wings oblong; keel obtuse. Fruit: pods erect, sessile, coriaceous.

This is a common species of purple Vetch in the mountain regions. It has much foliage, composed of from fifteen to twenty-five tiny oblong leaflets borne on each of the leaf-stalks, which branch from the main stems. The flowers grow in dense roundish heads, and the little leaflets are rounded and entire at the apex.

Each individual flower, like many of those of the Pea Family, is composed of five irregular petals, the large upper one, called the standard, being turned backwards when in full bloom, and the two side ones forming wings, while the two lower ones are united to form a kind of pouch, called the keel, which encloses the stamens and style.

The traveller will note that an easy way to distinguish 


\section{PLATE LII}

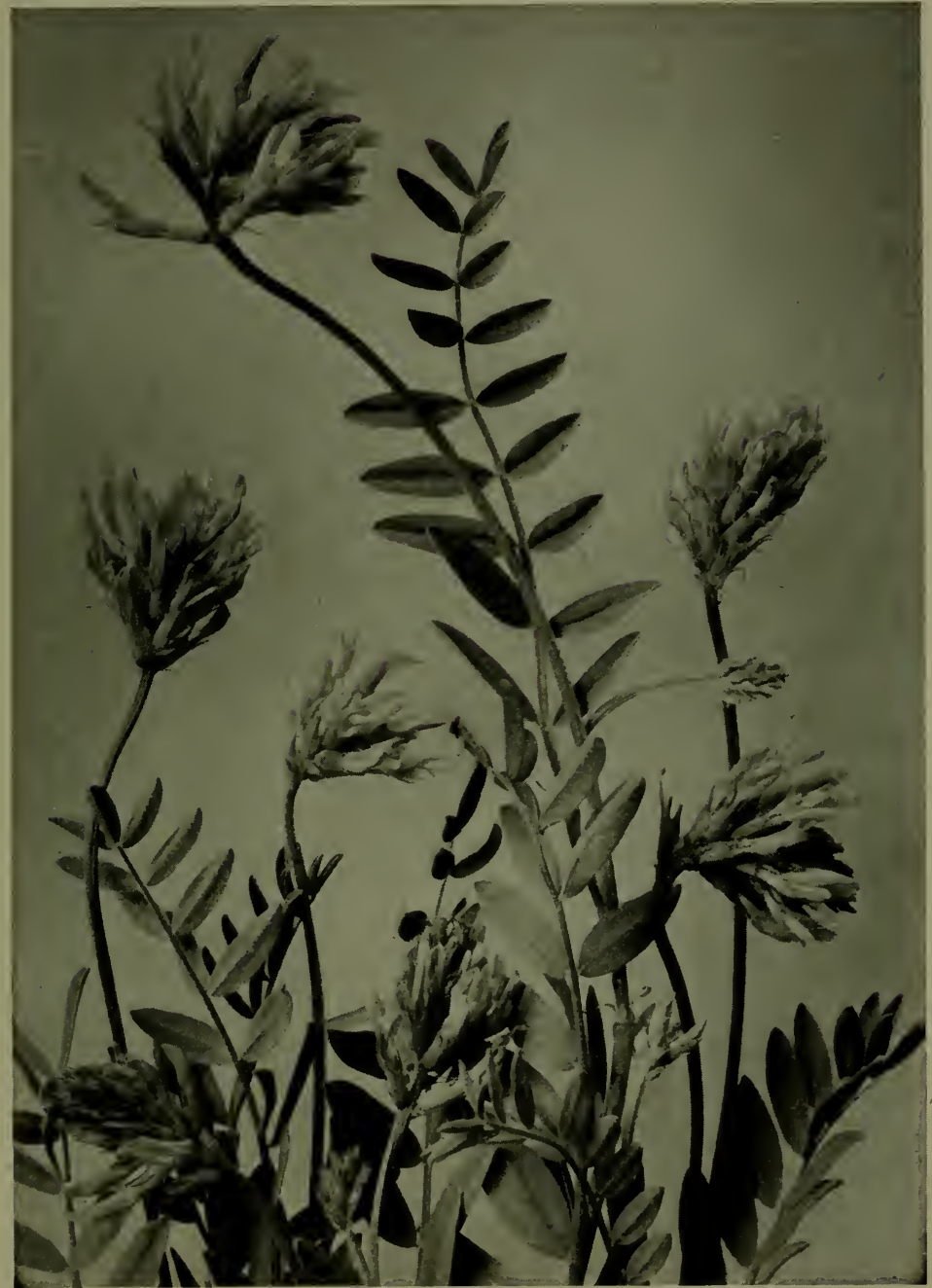

Ascending Milk Vetch (Astragalus adsurgens) 
PLA TE LIII

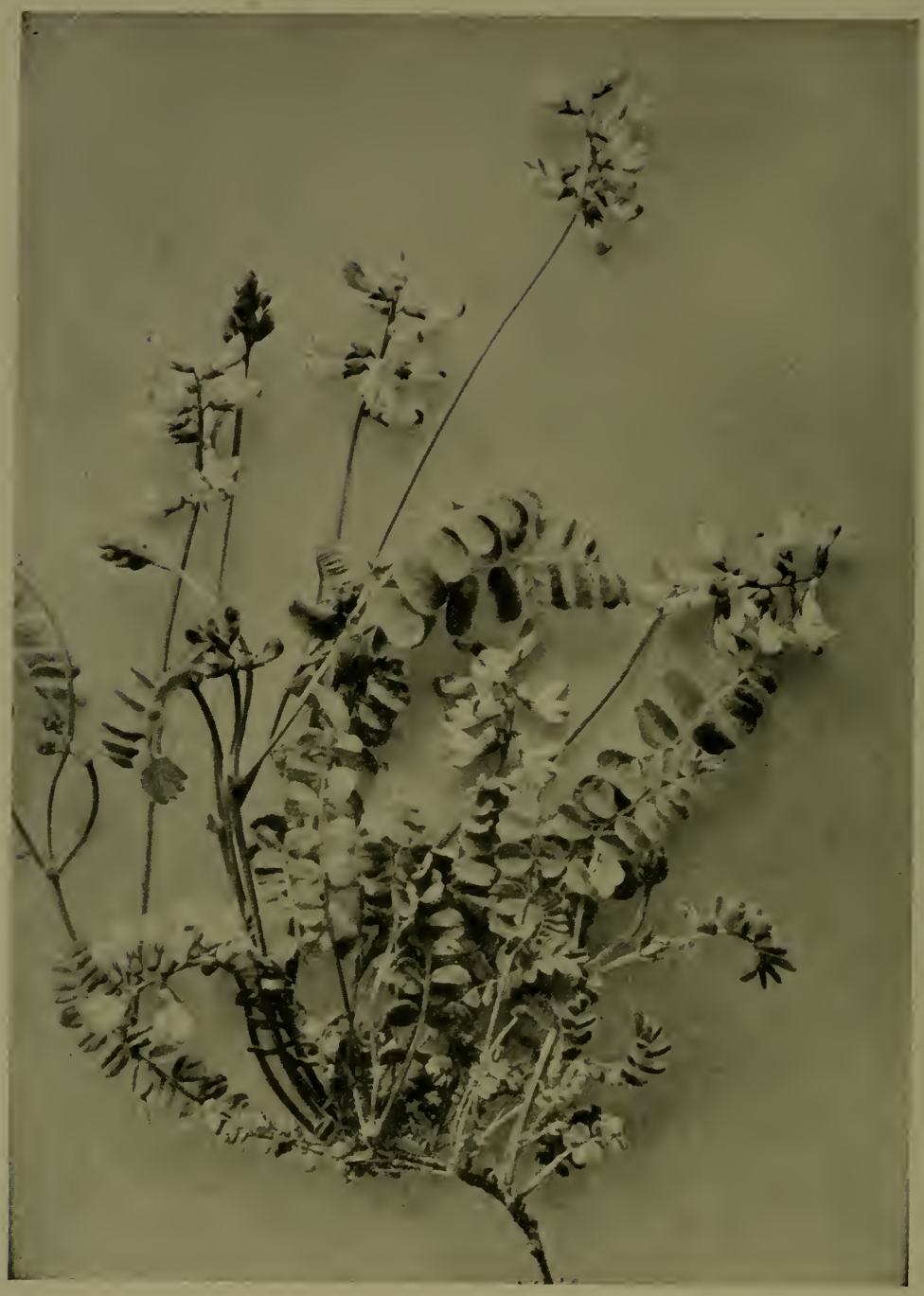

Alpine Milk Vetch (Astragalus alpinus) 
Astragalus adsurgens from Orytropis viscida (which it much resembles) is by observing two things. In the first place, the flower-stalks of the Astragalus branch out from all parts of the main stems of the plant, together with the leaf-stalks; whereas the flower-stalks of the Oxytropis are naked and grow directly up from the base of the plant. In the second place, the keel of the Astragalus flower is rouncled, whereas that of the Oxytropis is very pointed.

Astragalus hypoglottis, or Purple Milk Vetch, very closely resembles the preceding species, but may be distinguished from it by the fact that its leaflets are indented or notched at the tips, whereas those of the Ascending Milk Vetch are slightly rounded and perfectly entire.

Astragalus alpinus, or Alpine Milk Vetch, is a dainty pale maure species, with small loosely flowered heads and delicate foliage. It is frequently found at very high altitudes.

Astragalus Macounii, or Macoun's Milk Vetch, is a tall plant with sparse foliage and a few long loosely flowered heads of pale mauve, or white tinged and edged with mauve. The stems grow very erect and are quite slender. It usually is found in rocky places.

Astragalus conz'allarius, or Slender Milk Vetch, is a lovely fragile species, quite unmistakable by reason of its very fine grass-like stems, tiny, narrow, silky leaflets, and little, scanty, pinkish-mauve blossoms, that grow far apart in long slender racemes, giving the plant a beautiful feathery appearance.

\section{ALPINE OXYTROPE}

\section{Oxytropis viscida. Pea Family}

Stems: viscid-pubescent. Leaves: odd-pinnate; leaflets in numerous pairs, oblong-lanceolate, somewhat acute. Flowers: peduncles longer 


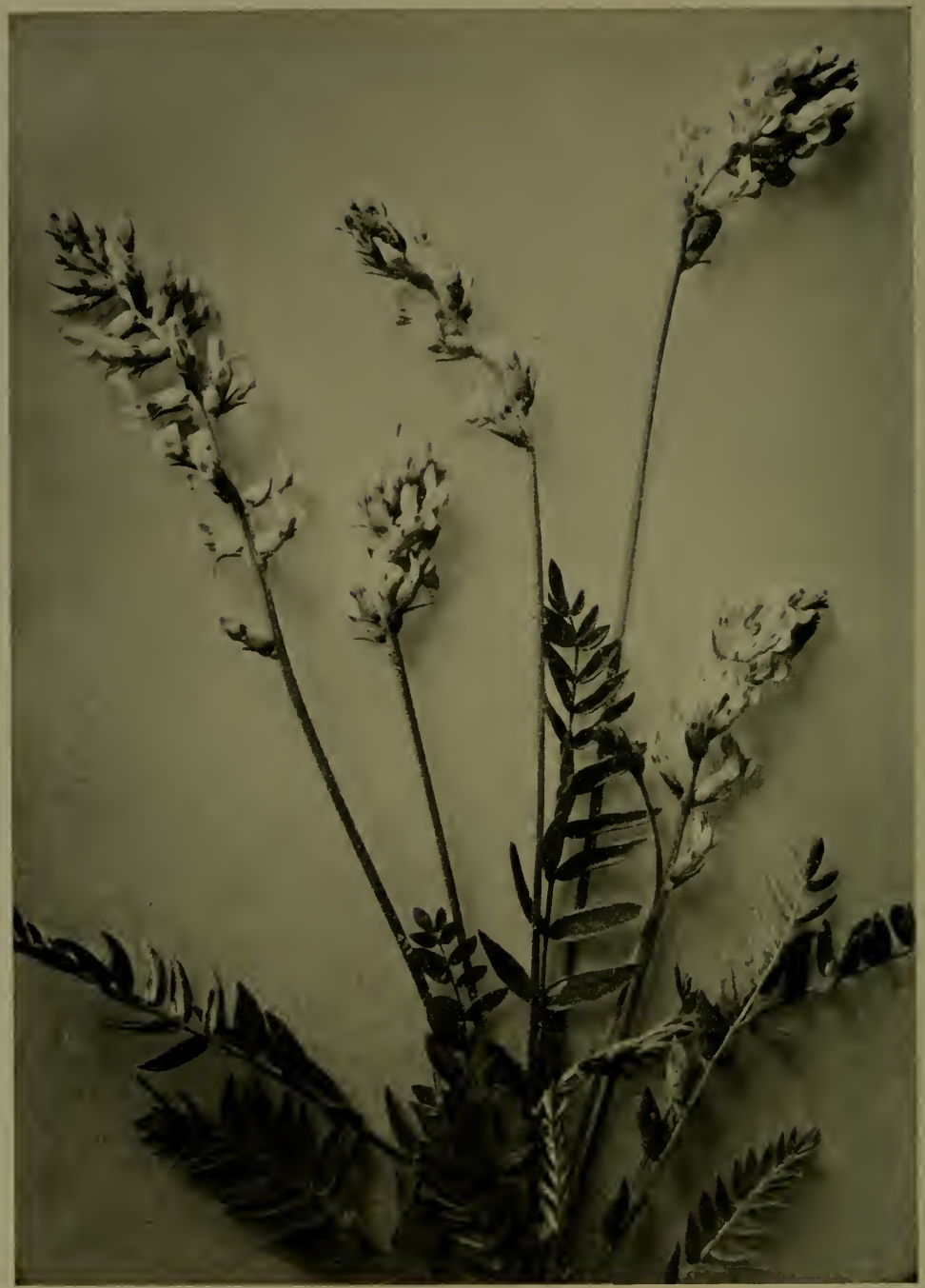

Alpine Oxytrope

(Oxytropis viscida) 
than the leaves; spikes subcylindrical; teeth of the calyx subulate, about the length of the tube; legumes short, terete, acuminate.

As remarked before, Oxytropis differs from Astragalus in having flowers with very pointed keels and long naked flower-stalks that grow up directly from the base of the plant; also its flower-spikes are more elongated than those of the Ascending and Purple Milk Vetches, which are roundish. The Alpine Oxytrope is a hairy, rather sticky plant, and bears blossoms of many shades of gray-blue, violet, mauve, purple, and creamy white.

Oxytropis splendens, or Showy Oxytrope, is rightly named, for its handsome bright purple-blue or purple-pink flowers, growing in dense spikes on the top of the long straight stalks, and its quantity of silvery silky foliage render it a remarkably handsome member of the Pea Family. The whole plant, including the stalks, leaves, and calyx, is extremely woolly.

Oxy'tropis deflexa, or Drooping-fruited Oxytrope, is a soft pubescent or silky plant with leaves bearing twelve to sixteen pairs of narrow pointed leaflets. The small pale purple flowers grow in slender spikes on stalks which far exceed the leaves in length. The calyx is nearly as long as the corolla and is covered with short black and longer white hairs. The fruit is the most remarkable feature of this plant, it is very strongly deflexed.

Oxytropis podocarpa, or Inflated Oxytrope, is an arctic and alpine plant, which grows only from one to four inches high and has violet flowers and tiny very hairy stalks and leaves. The main stems grow partly underground and are imbricated, - that is to say, they are covered with numerous small overlapping leaves; but the pods are the most noticeable feature, being abnormally large and inflated. 
This plant is frequently found growing flat upon the ground.

\section{PURPLE HEDYSARUM}

Hedysarum boreale. Pea Family

Stems: erect, glabrous, generally simple. Leaves: odd-pinnate, shortpetioled; leaflets oblong, obtusc, and often mucronate at the apex. Flowers: in long loose racemes, deflexed.

This is a tall handsome plant very common among the mountains. The leaves are short-stalked and have eleven to twenty-one oblong leaflets which are rounded at the base. The stiff erect racemes of deflexed violet-purple flowers are longer than the leaves and the pods are drooping and have three to five oval strongly reticulated joints.

The white or cream-coloured species, Hedy'sarum sulphurum, is described in the White to Green Section.

\section{COW VETCH}

\section{Vicia Cracca. Pea Family}

Stems: tufted, slender, weak, climbing or trailing. Leaves: pinnate, tendril-bearing, nearly sessile; leaflets eighteen to twenty-four, linear, obtuse, mucronate; peduncles axillary. Flowers: in spike-like dense racemes, reflexed. Not indigenous.

A lovely climbing or trailing Vetch, with dense spike-like racemes or deep purple-blue flowers and quantities of delicate foliage; the leaves, which are pinnately divided into numerous tiny leaflets, having thread-like tendrils at their tips.

Vicia americana, or American Vetch, has the same nearly sessile pinnate leaves and slender weak stems as the preceding species. It also climbs and trails over every bush and shrub in its vicinity, clinging to them by means of its tiny tendrils; but it differs entirely from $V$. Cracca in its 
flowers, which are larger, more mauve in hue, and grow in a scanty, very loose fashion, as opposed to the dense spike-like racemes of the Cow Vetch.

To see the mountain woods blued by these two graceful plants recalls Emerson's reference to how

"The million-handed Painter pours

Opal hues and purple dye"

out upon the flowers of the forest.

The Astragalus, Oxytropis, Hcdysarum, and Vicia all belong to the Pea Family, and therefore their flowers are all papilionaceous; that is to say, they have irregular butterfly-shaped blossoms.

\section{MARSH VETCHLING}

Lathyrus palustris. Pea Family

Stems: angled, winged, slender. Leaves: leaflets two to four pairs, lanceolate, oblong, pointed at the apex, rounded at the base. Flowers: style dilated and flattened above, hairy along the inner side. Fruit: pod flat, seeds globular.

The purple flowers of this plant grow in loose-headed racemes where the ground is moist. The slender stems are angled and winged, the three or four pairs of leaflets are oblong and pointed, and the tendrils terminating the stalks are branched.

\section{WILD FLAX}

\section{Linum Lewisii. Flax Family}

Stems: slender, erect. Leaves: crowded, sessile, oval-linear, acute. Flowers: on long pedicels; sepals oval, obtuse; petals five, large, blue, fugacious.

A slender dainty plant, which bends and bows to every passing breeze, and bears terminal clusters as well as racemes of lovely cerulean flowers. 
"Blue were her eyes as the fairy flax,"

wrote Longfellow, and if you once see the wonderful blue of these blossoms you will well understand the compliment intended, for they are a marvellous colour, and so frail and translucent that they wither at a single touch, while the delicately veined petals fall almost as soon as they develop into the perfect flowers; the stems, on the contrary, though slim, are remarkably tough. A really blue flower is a rarity in the mountains. There are many mauves, heliotropes, violets, purples, and lilacs, but few true blues.

The word limum comes from the Celtic word lin, meaning " thread," and from it also is derived the English word "linen," together with all its variations. The seeds of the Flax contain oil.

\section{CROWBERRY}

Empetrum nigrum. Crowberry Family

Much branched, the branches spreading, densely leafy. Leaves: linear-oblong, crowded, thick, obtuse, the strongly revolute margins roughish. Flowers: very small, purplish, solitary in the upper axils; sepals and petals mostly three. Fruit: a black drupe, containing six to nine nutlets.

This black-berried herbaceous shrub resembles a Heath, and grows in large dense mats on the mountain sides at high altitudes. The numerous short branches are thickly covered with tiny narrow leaves; the purplish flowers are inconspicuous, and the berries, which are large, round, and of a dull black colour, are a favourite fruit with the alpine birds.

\section{EARLY VIOLET}

Viola nephrophylla. Violet Family

Acaulescent. Rootstocks short and thick. Leaves: long-petioled, cordate, with a broạd sinus, the early ones reniform, the lattẹ onẹs 


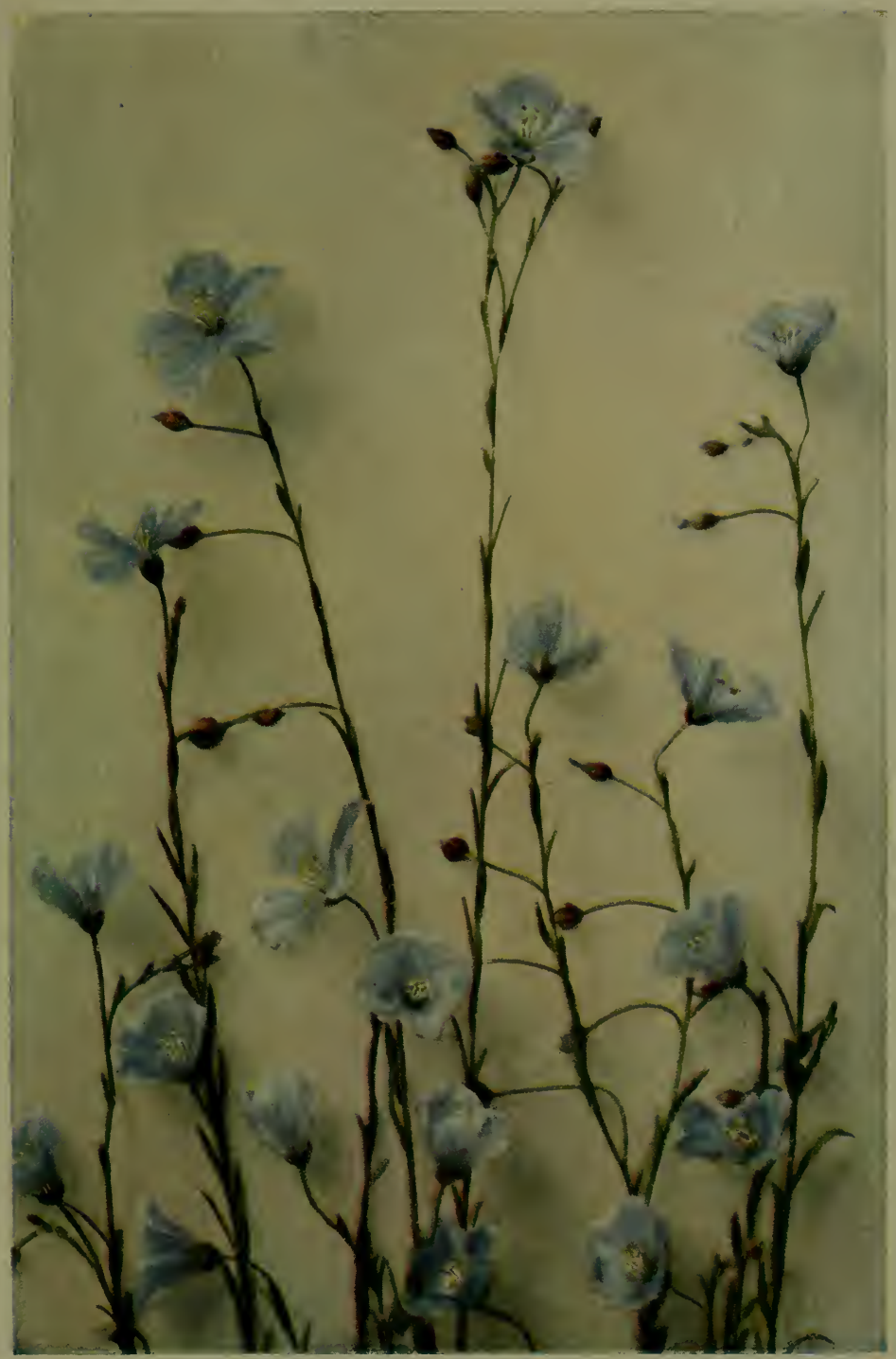

WILD FLAX

(Linum Lea'isii) 

acute or acuminate, crenately toothed. Flowers: large; petals villous at base; spur saccate.

This large Early Violet is really of a true violet colour ; it grows most luxuriantly in very moist ground, usually on the low banks of streams or in the marshes, for it is there that

"The purple violets lurk,

With all the lovely children of the shade."

Poets have ever loved and praised the Violet. The Bard of Avon sang of how

"Violets blue,

And lady-smocks all silver white,

And cuckoo-buds of yellow hue

Do paint the meadows with delight";

later causing Oberon to relate:

"I know a bank whereon the wild thyme blows,

Where ox-lips and the nodding violet grows."

Milton told of the

"Violet embroidered vale" ;

and Scott claimed that

"The violet in her greenwood bower,

Where birchen boughs with hazel mingle,

May boast herself the fairest flower

In forest glade or copsewood dingle."

Long before Shakespeare's day, however, the ancient Arabians sang its praise. It was the favourite flower of Mahomet, just as it was that of Napoleon in modern times, and has since become the emblem of the Bonapartists, who still wear it as a token of their devotion to a lost cause, remembering, perhaps, Shakespeare's proverb that

"Violet is for faithfulness."

No legitimist in France will ever wear these flowers. 
The Early Violet has five large petals that are hairy at the base, the lower one being marked with a tiny, darkveined yellowish-white patch on its face, and protruding at the back into a small rounded spur. The leaves are broad and conspicuously veined, many of them being folded inwards when young.

Viola adunca, or Dog Violet, is a smaller dark purple or white species which grows on dry ground and sends out runners that bear many blossoms. The low stems branch out from the base, the leaves are ovate and somewhat cordate, and the spur is rather slender and curved.

Viola Selkirkii, or Selkirk's Violet, has dark green orbicular, deeply cordate, crenate leaves, whose upper surface is sparingly beset with short hairs near the margin. The pale violet flowers have an obtuse spur and are beardless.

Viola palustris, or Marsh Violet, has leaf and flower stalks arising from a very slender creeping rootstock. The flower stalks are longer than the leaf stalks. The leaves are thin cordate, broadly ovate and crenulate, the petals are pale lilac streaked with darker veins or sometimes nearly white, the flower is slightly bearded, the spur is short and the stigma not bearded but somewhat beaked. This is not a common species.

\section{CUT-LEAVED ANGELICA}

Leptotania multifida. Parsley Family

Stems: from a large fusiform rootstock. Leaves: pinnately decompound. Flowers: in large umbels. Fruit: oblong-elliptical, carpel with dorsal and intermediate ribs.

The stems of this handsome Angelica grow from one to three feet high and are very leafy at the base. The seg- 
ments of the ternate and pinnate leaves are finely cut, and the small brownish-purple flowers grow in round umbels three to four inches in diameter, usually without an involucre. The lateral wings of the fruit are broad, very thick and corky, and the seeds are flat, the seed-face being concave. The oil-tubes are obsolete.

\section{MACOUN'S GENTIAN}

\section{Gentiana Macounii. Gentian Family}

Stems: slender, simple. Leaves: linear. Flowers: solitary at the ends of elongated erect peduncles; calyx-lobes lanceolate, acuminate, their mid-ribs decurrent on the tube; corolla narrowly-campanulate, its lobes spatulate-oblong, fringed on both sides, and almost toothed around the apex.

A lovely deep blue Gentian, found in moist places, but not very common. When the days begin to shorten and the earth is flooded with the final glory of those scarlets and yellows that precede and presage decay, then like a beautiful benediction the Gentians, "coloured with Heaven's own blue," are spread abroad, opening their petals to the sunshine at midday and closing them again suddenly at the first touch of the chill winds that blow off the ice-fields.

In the early fall of the year,

"Then doth thy sweet and quiet eye

Look through its fringes to the sky,

Blue, blue, as if that sky let fall

A flower from its cerulean wall."

There lies at all times a curious silvery tinge upon the exterior of the four large fringed lobes of the corolla, which are delicately and darkly veined. The two outer calyxlobes are longer and narrower than the two inner ones, and the buds are very long and pointed. Whenever you try to 
pick one of these Gentians, you will find that the whole plant comes up out of the ground at the slightest pull. They are extremely elusive flowers, seldom reappearing in the same place for two consecutive years, since, being annuals, and therefore perpetuated by seed alone, their reappearance the following season depends altogether upon the direction of the wind which blows the little hairy scales hither and thither, and by good fortune deposits a few where the moist earth enables them to germinate.

Gentiana Amarella var. acuta, or Northern Gentian, may readily be distinguished by the fringed crown set within the throat of the corolla-tube. The flowers are quite numerous, growing in clusters on short stiff stalks that spring out of the main stem; they are usually pinkish-purple, but sometimes white. The traveller should specially note that the corolla is divided into five lobes at the top, and that the tiny roots grow close to the surface of the soil and are very easily pulled up.

Gentiana propinqua, or Four-parted Gentian, is somewhat like the preceding species, but has larger, brighter blue flowers, which are not nearly so closely clustered together; and it is a much more graceful plant. The corolla is fourparted, or cut into four lobes, as the name implies, and the calyx is also four-cleft. These Gentians are occasionally white.

Gentiana arctophila, or Alpine Gentian, is a tiny dwarf species resembling $G$. propinqua. It is found at immense altitudes.

Gentiana prostrata, or Dwarf Gentian, has very weak and often procumbent stems. The leaves are covered with a soft white bloom and have white hairy margins, while the flowers are solitary and of a lovely azure-blue colour, also 
PLATE LV

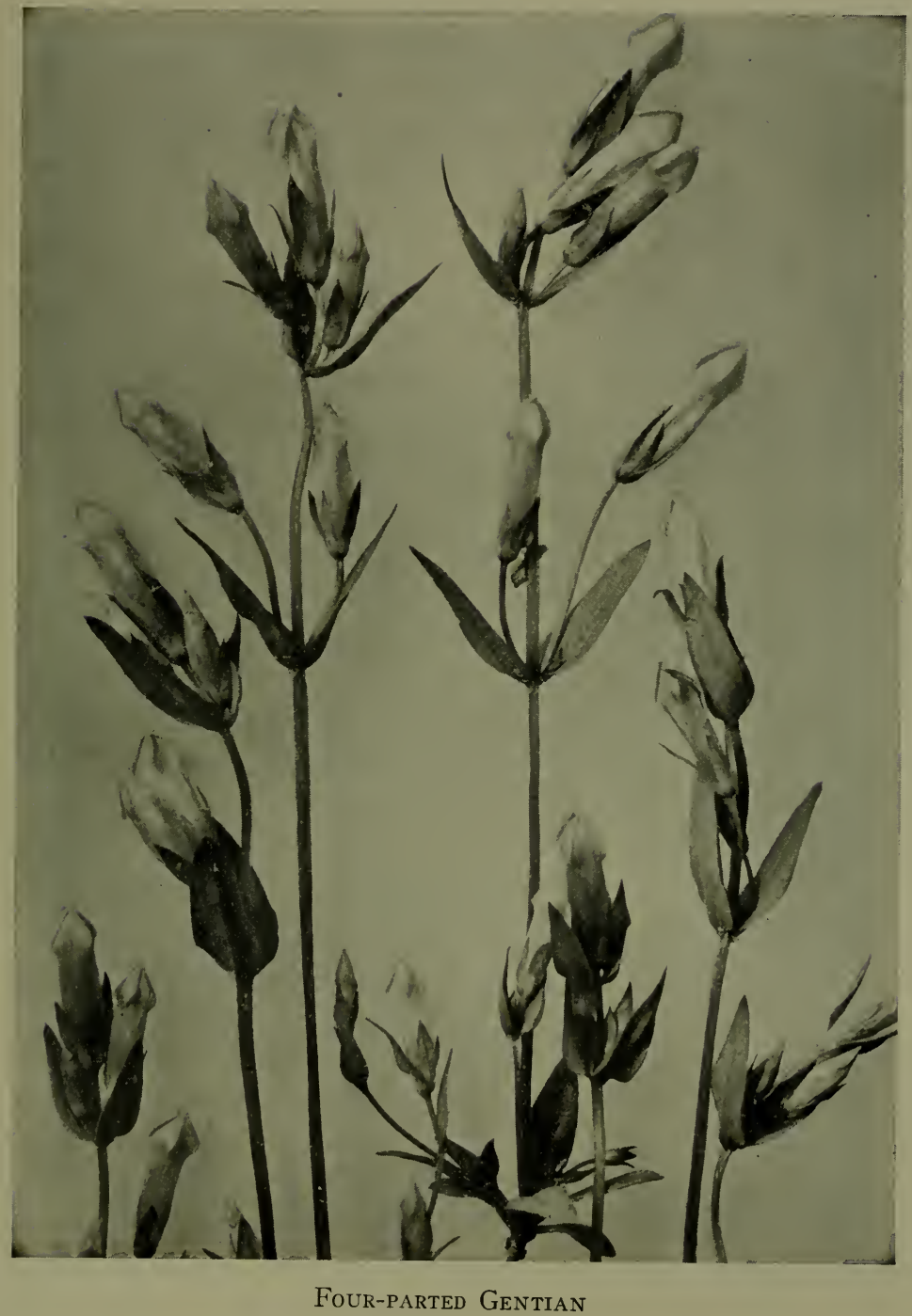

(Gentiana propinqua) 
very occasionally white. It is an exceedingly tiny plant, and has been found at an elevation of .10,000 feet.

Gentiana affinis, or Large Gentian, has oblong obtuse leaves. In this tall handsome Gentian there is a very beautiful contrast between the rich green foliage and the azureblue flowers. These flowers grow in dense clusters among the leaves on the top of the stems; each one has a large, gray, greenish-blue corolla, divided into five spreading lobes, which are of a wonderful cerulean hue inside, marked and spotted with white. The tips of these lobes are very pointed, and sometimes the green calyx-lobes equal them in length, showing between their divisions, while at other times they are quite minute.

Gentiana glauca, or Pale Gentian, is a small low-growing plant with tiny oval basal leaves forming a rosette, and a few green-blue flowers, subtended by a pair of bracts, at the top of the short stalks which are only two to four inches high. The calyx is campantlate, and the corolla tube is cylindrical with ovate obtuse lobes.

\section{SPURRED GENTIAN}

\section{Halenia deflexa. Gentian Family}

Stems: single or branched, slender, erect. Leaves: the basal ones obovate or spatulate, obtuse, narrowed into petioles, the stem ones ovate, acute sessile, the uppermost smaller. Flowers: terminal and axillary. Fruit: capsule narrowly oblong, two-valved, seeds globoseovoid, smooth.

A plant much resembling a Gentian, with tall erect stiff stems bearing pairs of ovate leaves up them, and having a tuft of larger ones at the base. The dull greenish-purple, rarely white, terminal and axillary flowers are most curiously shaped, having a campanulate corolla four to five cleft 
with the lobes convolute in the bud, and each with a hollow deflexed spur or projection below.

\section{BLUE GREEK VALERIAN}

Polemonium confertum. Polemonium Family

Stems: from a tufted rootstock. Leaves: alternate, leaflets mostly two to three divided, the divisions from round-oval to oblong-linear. Flowers: dense, corolla with rounded lobes. Fruit: ovules three in each cell.

This species of Greek Valerian grows at high altitudes, the bright blue flowers being erect, fragrant, and growing in densely congested heads. The plant is hairy, the petioles of the radical leaves are conspicuously scarious-dilated and sheathing at the base, and the leaflets are very small, and so crowded that they appear to be growing in fascicles or whorls.

Polemonium humile, or Purple Greek Valerian, has shorter, stouter stems than the preceding species, and is much branched. The leaflets are mostly oblong, and the purplish flowers grow in flat-topped clusters, the ample, rounded lobes of the corolla being much longer than the tube. The seeds are one or two in each cell. This is almost an arctic-alpine plant.

\section{MOUNTAIN PHACELIA}

Phacclia sericea. Water-leaf Family

Stems: simple, virgate, canescent, leafy to the top. Leaves: pinnately parted into numerous linear and again pinnatifid divisions, silky-canescent. Flowers: in short spikes, crowded in a naked spike-like thyrsus; calyx-lobes linear; corolla very open-campanulate, cleft to the middle; stamens long exserted.

A glorious plant, with rich purple-blue flowers clustered in huge long spike-like panicles, and handsome deeply cleft 
foliage, which is covered with a soft white down. The long protruding stamens give a feathery appearance to the open bell-shaped blossoms, and as it grows at extremely high altitudes, where flowers of any kind are rather rare and large showy ones almost unknown, the Mountain Phacelia is a real treasure-trove to the traveller. It has a very strong disagreeable odour.

Phacelia heterophy'lla, or Blue Phacelia, has stout roughhairy stems, and lanceolate entire pointed silky white-hairy leaves, pinnately and obliquely veined, the lower one tapering into a stalk and usually having a pair of lateral leaflets. The bluish-purple flowers grow in a short dense terminal spike and smaller axillary spikes, and the filaments are much exserted and sparingly bearded.

\section{FALSE FORGET-ME-NOT}

\section{Lappula floribunda. Borage Family}

Stems: soft-hirsute, rather strict. Leaves: oblong to linear entire, sessile. Flowers: in numerous racemes, nearly erect, densely flowered; corolla funnel-form, five-lobed. Fruit: nutlets keeled, papillose-tuberculate on the back, the margins armed with a single row of flat subulate prickles.

There have probably been more arguments between travellers over these flowers than over any other plant that grows in the mountain regions. Ninety-nine persons out of every hundred will gather the lovely sky-blue blossoms, delighting in their beauty and inhaling with joy the delicate fragrance of their perfume, under the firm conviction that it is the true Forget-me-not they are picking; whereas - alas for the shattering of a pretty romance! - it is only the sweetscented blossoms of the False Forget-me-not they are gathering, which have as usual practised a successful deception upon the unwary. 


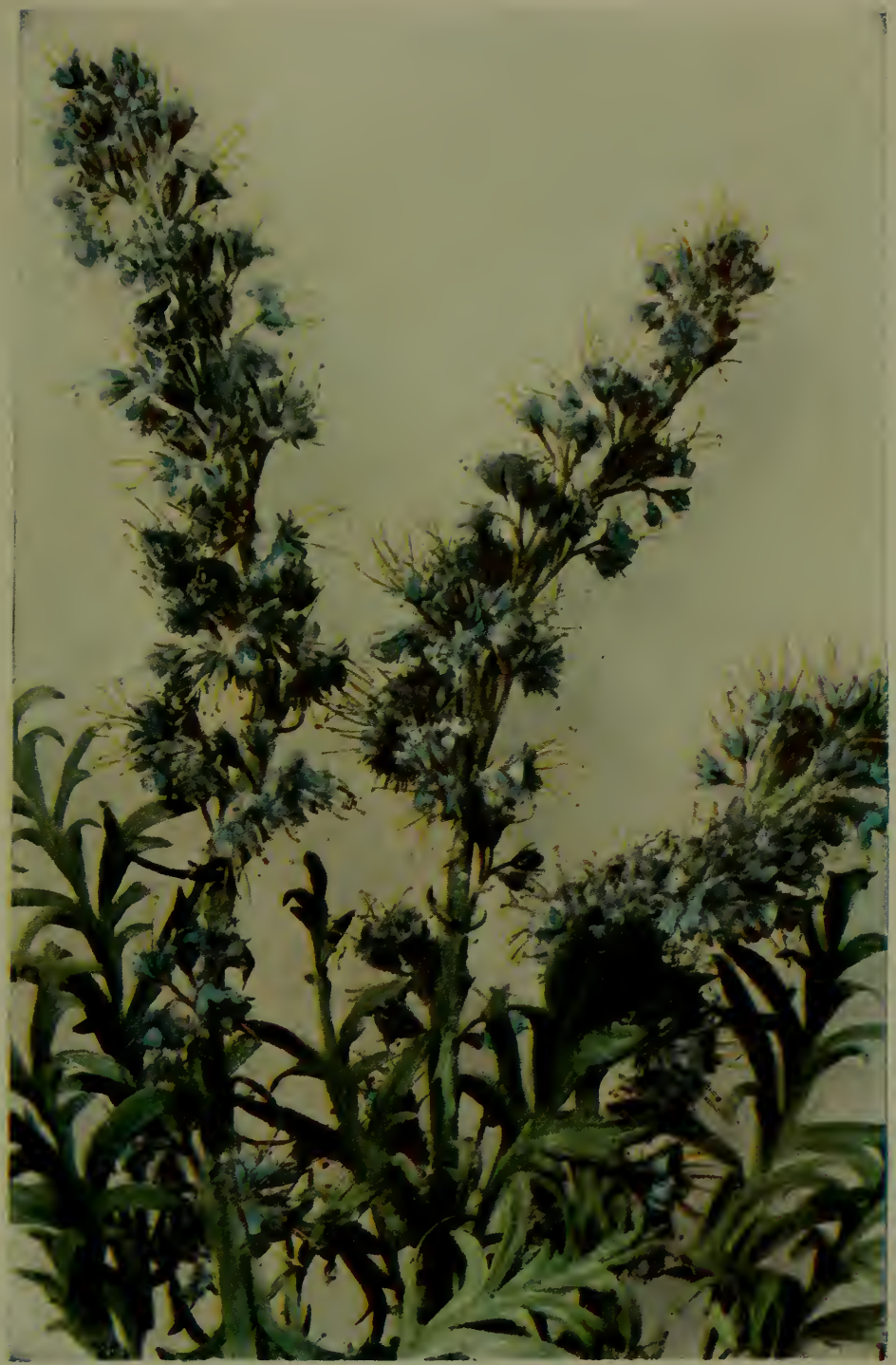

Motemtain Phacelia

(Phacclia : cricea) 

The False Forget-me-not may, in reality, be easily distinguished from the true species by a very simple fact, which, once understood and noted, will never again be overlooked. When in fruit the "False" species bears numerous nutlets covered with prickles, in fact tiny burs, which give it the common name of Stickseed, and certainly these little seeds do stick, and stick very fast indeed, to the clothing of persons and the fur of passing animals. The true Forget-me-not has no burs.

The stems and long narrow leaves of the Lappula floribunda are covered with a slight soft down. It grows very tall under favourable circumstances, such as near water and on the open sunshiny slopes, and its flowers, blue as heaven itself, or very occasionally white, are funnel-form, the tube being very short and having its throat nearly closed by five flat lobes, which form a circular arching crest in the centre. The tiny stamens, and the style with its minute capitate stigma, are set inside this bright yellow circle, or " eye."

It matters little, after all, whether these flowers are "False" or true; they are beautiful to look upon, and very fragrant, as they hold their

\section{"Festival}

Of breaking bud and scented breath"

high up in some alpine meadow, where the air is fresh and wholesome and where the whole world seems full of wonderful possibilities.

Lappula diffusa, or Rock Stickseed, is somewhat like the preceding species, but not so tall, and has wider and more pointed leaves. The blue flowers, too, are larger, though fewer in number, and the extremely prickly nutlets have stalks more than a quarter of an inch long.

Lappula echinata, or Burseed, has much smaller leaves 
and very tiny bright blue flowers, each individual blossom being little larger than a pin's head. These flowers grow in close leafy-bracted racemes, which are more or less onesided, and when in fruit the plant bears innumerable tiny burs. This is an introduced plant.

\section{MOUNTAIN FORGET-ME-NOT}

\section{Myosotis alpestris. Borage Family}

Stems: erect, tufted. Leaves: oblong, linear. Flowers: in dense racemes; calyx five-parted, hirsute; corolla salver-form, the throat with small blunt crests at the base of the rounded lobes.

This is the real true Forget-me-not. It grows from about four to six inches high and is found only at high altitudes. Its tiny turquoise flowers are very fragrant. Unlike the prickly burs of the "False" species, the nutlets of the true Forget-me-not are quite smooth.

There are innumerable stories told concerning these blueeyed flowers, which are the emblems of undying love and are identified with our most romantic sentiments. One of the most charming legends about them runs thus: ·

"When to the flowers so beautiful

The Father gave a name,

There came a little blue-eyed one

(All timidly it came),

And, standing at the Father's feet,

And gazing in His face,

It said, in low and trembling tones,

Yet with a gentle grace:

'Dear Lord, the name Thou gavest me, Alas! I have forgot' ;

Kindly the Father looked Him down And said, 'Forget Me not.", 


\section{TALL LUNGWORT}

\section{Mertcnsia paniculata. Borage Family}

Rough-pubescent. Stems: erect, branched above, the branches slender. Leaves: thin, pinnately veined, those of the stem ovate-lanceolate, acuminate; basal leaves ovate, rounded. Flowers: several-flowered in loose terminal panicles calyx-lobes acute; corolla funnel-form, crested in the throat.

The Tall Lungwort grows from one to three feet high, and is one of the handsomest members of a family of coarse and hairy plants. It has very showy blue flowers, their tubes crested in the throat and the lobes only slightly spreading. These grow in loose terminal clusters.

Probably it is because there are so few really blue mountain wild flowers that we specially prize this striking plant. On every hand we see various shades of purple, mauve, violet, and heliotrope,- but very rarely of blue.

"Blue! 'Tis the life of heaven, the domain

Of Cynthia, the wide palace of the sun, The tent of Hesperus, and all his train, The bosomer of clouds, gold, gray, and Blue! 'Tis the life of waters, ocean And all its basal streams.

Blue! Gentle cousin of the forest green, Married to green in all the sweetest flowers."

Mertensia oblongifolia, or Blue Lungwort, is not so tall as the preceding species, growing only from four to eight inches high, the stems usually solitary from the short, thick, corn-like root. The leaves are oblong, and rounded at the apex, the lower ones being smaller than these at the middle of the stem. The very bright clear blue flowers are numerous in a close terminal cluster, the narrow lobes of the fourparted calyx are minutely hairy, and the funnelform corolla has an abruptly dilated throat with pubescent crests at its 
base on a line with the stamens. The nutlets are dull and with obtuse angles, they are wrinkled at maturity. This plant grows in moist places.

\section{DRAGON HEAD}

\section{Dracocephalum parviflorum. Mint Family}

Stems: erect, leafy. Leaves: ovate-lanceolate, sharply cut-toothed. Flowers: in whorls, crowded in a terminal spike.

The leafy erect stems of this plant are crowned with dense whorled spikes of small purple-blue flowers, the upper lip of the small slender corolla is arched and notched, the lower one being three-cleft, with the large middle lobe again twocleft or notched at the end. The leaves are long-shaped and very sharply toothed, the lower ones being petioled and the upper sessile.

\section{HEART OF THE EARTH}

Prunella vulgaris. Mint Family

Stems: numerous, slender, erect or procumbent, usually simple. Leaves: thin, ovate or oblong, obtuse, entire or crenate. Flowers: in dense, bracted, terminal and axillary spikes; calyx cylindraceous, with hirsute teeth; corolla-tube inflated, bilabiate, the upper lip entire, arched, the lower lip spreading, three-lobed.

The dense purple spikes of the Prunclla are very common beside alpine streams and in the grassy meadows. This plant, which was called Prunclla by Linnæus, is more significantly named Brunclla, because it is supposed to contain a remedy for die Bräune, or the quinsy, and hence some ancient German botanist originally called it Brumellen.

It is not an attractive flower, for its elongated spikes, covered with dark reddish bracts, have usually only a few scattered blossoms on them, and even these are insignificant. 
The leaves grow in pairs up the stems, and are frequently marked with reddish patches.

\section{WOUNDWORT}

Stachys palustris. Mint Family

Stems: erect, strict, simple, retrorse-hispid on the angles. Leaves: firm, lanceolate, oblong, almost sessile, acute at the apex, subcordate at the base, dentate. Flowers: in clusters, forming an elongated interrupted spike.

The Woundwort has from six to ten reddish-purple flowers in each of the whorls that encircle its stem at intervals, and also bears a terminal cluster at the top. Stachys means " a spike," and refers to its elongated flower-spikes, while palustris signifies "growing in swamps," and is therefore peculiarly appropriate to this plant, which frequents very moist places. Probably it is sometimes called Hedge Nettle because the leaves resemble those of the true Nettle, but without the stinging properties of the latter. Stachys is a very hairy plant, its leaves and stems being all covered with quantities of fine hairs, and Gerade claims to have cured wounds by binding it over the cuts, and in olden days these plants were frequently employed to stop bleeding, hence the name of Woundwort.

\section{CANADA MINT}

Mentha canadensis. Mint Family

Stems: erect, simple or branched. Leaves: oblong, acute, sharply serrate. Flowers: all in short and dense, sessile, axillary glomerules; calyx oblong-campanulate, pubescent, five-toothed; corolla irregularly four-cleft.

The traveller has only to pick a spray of this plant to know its name, Mint, from Minthe, a lovely nymph whom 
the jealous Proserpine changed into a flower so that she might not win the admiration of Pluto, her lord and master. At least the memory of the ill-fated beauty is kept forever green and fragrant, for the leaves of the Mint contain numerous tiny glands in which is'secreted a volatile oil that has an excessively strong odour and flavour.

The flowers, which are either pinkish-purple or purplishpink, and very occasionally white, grow in dense little clusters in the axils of the leaves.

Mentha canadensis var. lanata, or Hairy Mint, closely resembles the preceding species, but has densely tomentose or lanate stems and under surfaces of leaves.

\section{BLUE-EYED MARY}

\section{Collinsia tenella. Figwort Family}

Stems: very slender and weak. Leaves: oblong or lanceolate, mostly obtuse at the apex and narrowed at the base, entire or sparingly toothed, the lower ones opposite, the upper ones in whorls. Flowers: on long pedicels; corolla variegated blue and white, the throat longer than the limb, which is two-lipped, the upper lip two-cleft, its lobes recurved, the lower lip larger and three-lobed.

A pretty, fragile, little plant, with numerous variegated blue and white blossoms. It grows thickly in moist places, seldom attaining more than eight inches in height. It is not unlike a very tiny Lobelia.

\section{LARGE PURPLE BEARD-TONGUE}

\section{Penstemon fruticosus. Figwort Family}

Stems: decumbent, defusely spreading, woody at the base. Leaves: ovate or lanceolate, serrulate or entire. Flowers: in glandular hairy terminal racemes, calyx five-parted, corolla tubular, moderately bilabiate, the upper lip two-lobed, the lower lip three-lobed and bearded within. Fruit: seeds numerous, angled but not winged. 
These handsome purple and pinkish flowers are an inch or more in length and form large mats of brilliant colour upon the rocks at very high elevations. The plant grows low upon the ground and has numerous short erect shoots, bearing the blossoms, which are tubular in shape and have two lips, the lower one being thickly bearded with soft white hairs. Penstemon comes from the Greek pente, "five," and stcmon, "a stamen," and refers to the large fifth sterile stamen, which is simply a filament without an anther and is densely hairy like the lower lip. It is to this pert little bearded tongue, which projects far beyond the other four fertile stamens, that the flower owes its common name.

Pcnstemon Mensicsii, or Small-leaved Beard-tongue, is a densely matted prostrate shrub with lateral leafy branches which bear erect flowering shoots two to six inches high. The leaves are small thick oval more or less dentate, most of the petioles and the flowering stems bearing several pairs of oblong leaf-like bracts. The purple corolla is tubularfunnel-form and bilabiate, the lower lip being bearded within, and the sterile filament is densely bearded.

Penstcmon procerus, or Blue Beard-tongue, has smooth, slender stems and lanceolate, entire leaves. The flowers are bright blue or violet, and are set in dense verticillate clusters round the stem, and in a more or less elongated head. The calyx is glandular-hairy and deeply cleft, and the funnelform corolla is half to three quarters of an inch in length and slightly hairy, the lower lip being bearded within.

Penstemon humilis, or Slender Beard-tongue, has numerous stems growing from a woody base. The basal leaves are spatulate or oblanceolate and short-petioled, and the upper ones are linear and sessile, also somewhat clasping, 
they are all entire or occasionally serrulate. The blue flowers grow in an upright, loose panicle, the corolla is tubularfunnelform and bilabiate within. The inflorescence is slightly viscid-pubescent.

\section{ALPINE SPEEDWELL}

Veronica alpina var. unalaschensis. Figwort Family

Stems: erect, slender, usually simple. Leaves: oblong, ovate, sessile, mostly rounded at both ends, nearly entire. Flowers: in a short narrow raceme; corolla rotate, its tube very short, deeply four-lobed, the lower lobe the narrowest.

These small azure-blue blossoms win the love of many a traveller by reason of the fact that they are among the last flowers he sees growing in the crevices of the great moraines below the glaciers, and are frequently the first ones to meet his eyes as he comes off the snowy ice-fields after making some arduous ascent.

"The little speedwell's darling blue"

renders it conspicuous, though its flowers are very small indeed, being clustered together at the tops of the stems. One marked peculiarity of the Speedwells is that the blossoms, which are cleft into four lobes, usually have the lower segment narrower than the rest. The Dutch call this plant "Honour and Praise," because it was once upon a time believed to contain valuable medicinal properties. Many claimed it to be an excellent remedy for scrofula, and it was the great Linnæus himself who grouped it, together with all its relatives, under the family name of Scrophulariacece, or Figwort.

The term Veronica suggests far more beautiful associations. Here the plant is named after Saint Veronica, who in her turn was thus canonized because, according to an an- 
cient tradition, she wiped the drops of agony from our Saviour's face when on His way to Calvary, and ever afterwards her kerchief bore the vera iconica, " the true likeness," of His sacred features.

Veronica humifusa, or Thyme-leaved Speedwell, may be recognized by its decumbent branching stems; that is to say, the stems are curved near the base and lie partly on the ground, rooting where the joints touch the earth. Usually these stems grow in pairs and bear at their upper ends spikes of pale gray-blue blossoms striped with dark blue, the tiny flowers also growing at close intervals lower down on the stalks. The small oblong leaves grow in opposite pairs. Occasionally the flowers are white.

Veronica americana, or Water Speedwell, is perennial by stolons, or leafy shoots developed in the autumn. The stems are stout, often rooting at the nodes, and usually branched. The leaves are lanceolate, acute, serrulate or entire and short-petioled. The peduncled racemes are borne in the axils of the leaves, and the flowers are pale blue with purplish stripes.

\section{BUTTERWORT}

Pinguicula vulgaris. Bladderwort Family

Stems: scape glabrous, tall. Leaves: from three to seven in a rosette at the base of the scape, entire, ovate, obtuse. Flowers: one-flowered; calyx five-parted; corolla bilabiate, the upper lip two-cleft, the lower one three-cleft, base of the corolla saccate and contracted into a nectariferous, acute, nearly straight spur.

At first sight the Butterwort looks like a lovely large purple violet, but a second glance reveals its rosette of very pale green leaves, with their involute margins, and the traveller at once recognizes the Pinguicula, its name being derived from the Latin pinguis, "fat," and referring to the 
horrible slimy greasy secretion with which its leaves are coated, and which renders them most repulsive to the touch.

The Butterwort is carnivorous like the Sundew, and by means of the colourless fluid secreted by the glandular hairs covering the leaves it catches insects and the irritation thereby set up causes the glands to exude an increased supply which becomes very acid and capable of digesting the animal matter entrapped. Later the dissolved nitrogenous matter is absorbed and assimilated by the plant. The Butterwort resorts to these evil insectivorous practices in order to obtain sufficient nitrogen for its nutriment, as it usually grows in places where the soil is deficient in this respect.

The flowers are of a rich purple colour, and are two-lipped, the upper lip being cleft into two and the lower lip into three lobes. These lobes are delicately veined and the lower ones are covered with white hairs. The corolla terminates behind in a long straight spur. The Butterwort always grows near water, and usually in swamps or other very moist places.

\section{ONE-FLOWERED CANCER-ROOT}

Orobanche uniflora. Broom-rape Family

Stems: one inch long, subterranean or nearly so. Leaves: none. Flowers: solitary, without bracts, corolla with a long curved tube spreading into two lips, five lobed, yellow bearded within. Fruit: capsule elongated, egg-shaped, seeds numerous.

The Orobanches are beautiful root-parasites, whom $\mathrm{Na}$ ture has rendered destitute of green foliage as a punishment for their thievish ways of imbedding their roots in those of honest plants, and thereby drawing nourishment from their neighbours, instead of manufacturing it for themselves. The One-flowered Cancer-root is stamped as a pirate by its short scaly subterranean stem and brownish scape-like 
peduncles, on which the solitary violet flowers are borne.

Orobanche fasciculata, or Naked Cancer-root, has scaly stems which are thickened and knotty below, and bear on their summits one or more clustered peduncles, and at the end of each of the latter is a solitary, purplish or yellowish flower. The calyx is five-toothed, and the corolla tubular, over an inch long, with five spreading lobes and somewhat bilabiate. This Cancer-root is parasitic on the roots of Artemisia, Eriogonum and other plants growing in sandy soil.

\section{BOSCHNIAKIA}

Boschniakia strobilacea. Broom-rape Family

Stems: four to twelve inches high. Leaves: none. Flowers: calyx short with two setaceous bractlets at base, irregular, the teeth subulate from a broad base, corolla ventricon, upper lip erect. Fruit: capsule globose, seeds light-coloured, with a spongy coat.

Boschniakia is a parasitic herb, and has stout, thick, purplish-brown clustered stems, the dense scales being much imbricated. It flowers from near the ground in cone-like spikes, and the bilabiate corolla has an entire upper lip, its margins involute, and a naked two-lobed lower lip, the stamens being densely woolly at the base. Its common host plants are Gaultheria and Arctostaphylos.

\section{HAREBELL}

Campanula rotundifolia. Campanula Family

Stems: slender, erect, simple or branched. Leaves: basal ones orbicular or broadly ovate to cordate; cauline ones sessile, linear. Flowers: buds erect on slender pedicels, flowers drooping or spreading; corolla campanulate, five-lobed.

These bells of brilliant purple-blue are familiar to every traveller in the temperate zone, for from "Bonnie Scot- 
land" to the Pacific Slope the Harebell graces many a hill and dale.

Poets in every age have sung of this flower, which is the real Bluebell of Scotland, the favourite floral emblem of the "Land o' cakes and brither Scots," for, as the old song says :

"Let the proud Indian boast of his jessamine bowers,

His pastures of perfume, and rose-coloured dells,

While humbly I sing of those wild little flowers,

The bluebells of Scotland, the Scottish bluebells."

The name rotundifolia refers to the roundish heartshaped basal leaves of the plant which wither early, while the stem-leaves, which are numerous, narrow and pointed, remain. A marked characteristic of these flowers is that, although the buds grow erect on their slender stalks, the fullblown blossoms droop or are horizontal in order to protect their pollen from the rain. The name Harebell refers to the hair-like stems of the plant, and the common term Bluebell is usually reserved for the Wild Hyacinth, which is a very different flower, having thick juicy stalks and resembling the garden species.

The Harebell is extremely hardy and may be found in the crevices of the cliffs, defying the fierce alpine storms or growing on dry wind-swept meadows, or striking its roots into the tiniest patch of soil, so as to gain a foothold on the edge of some terrific precipice, where its delicate bells, so " darkly, deeply, beautifully blue," bend but never break before the blustering gale. This wonderful vitality of the Campanula is commemorated by Sir Walter Scott when, describing Ellen in The Lady of the Lakc, he says:

"E'en the light harebell raised its head Elastic from her airy tread." 
PLATE LVI

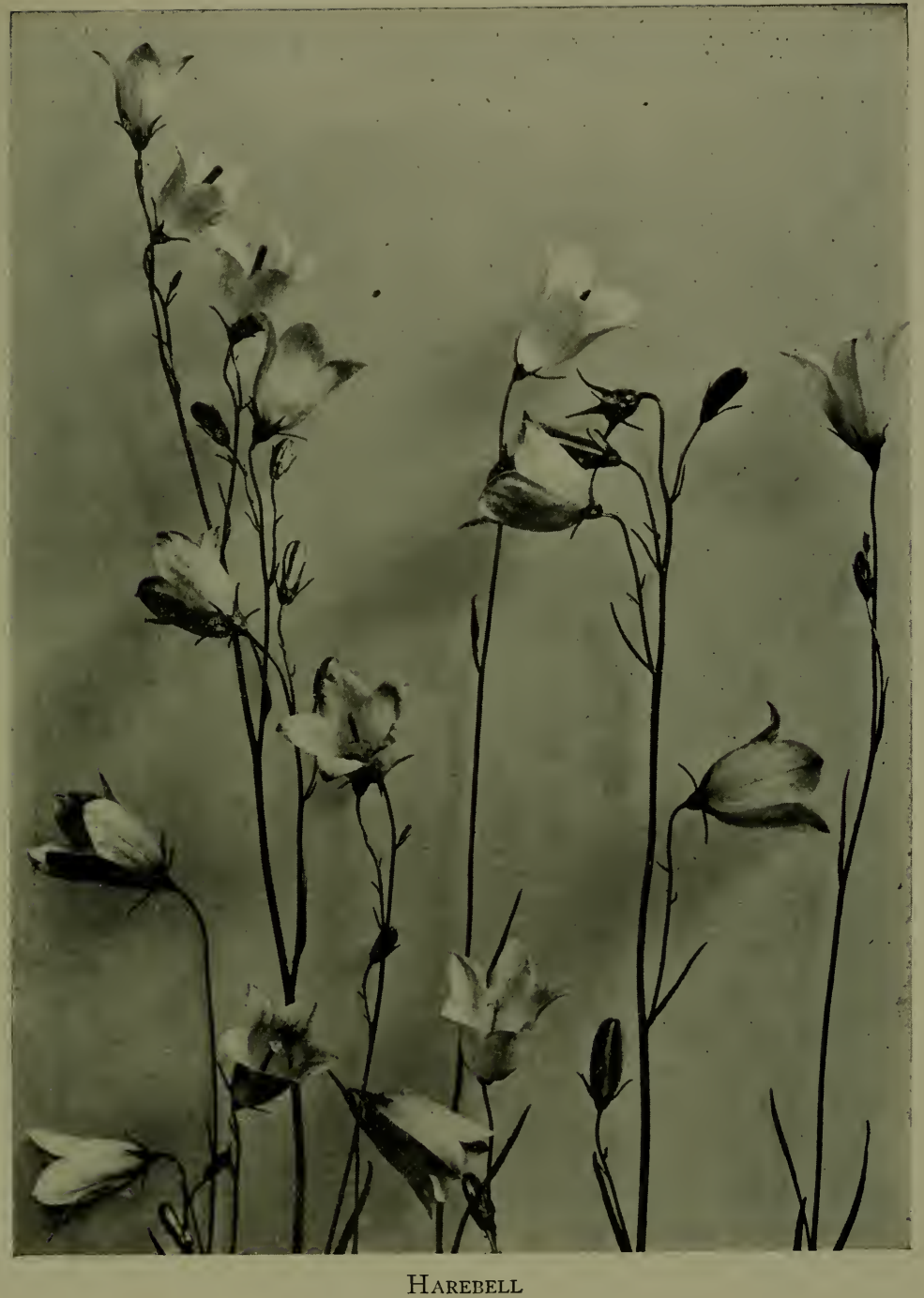

(Campanula rotundifolia) 
Campanula-lasiocarpa, or Arctic Harebell, is a low-growing species with linear acute sessile, usually entire upper leaves, the lower ones being spatulate and narrowed into petioles, while the bright blue flowers are nearly erect and solitary on the short stalks. This Harebell grows on the alpine summits.

\section{BROOK LOBELIA}

Lobelia Kalmii. Lobelia Family

Stems: leafy, glabrous, paniculately branched. Leaves: lower ones spatulate, obtuse, almost entire; upper ones sessile, linear, acute. Flowers: in loose racemes; calyx-tube turbinate, hemispheric, lobes lanceolate; corolla-tube straight, oblique, divided to the base on one side, two-lipped, irregularly five-lobed.

Those who are familiar with the cultivated garden species of Lobelia will easily recognize the mountain Brook Lobelia, which usually grows at the extreme edge of a stream, or half immersed in some warm wet swamp, where its grasslike stems bearing their racemes of sky-blue blossoms, spring up in little companies amongst the water-weeds, the Butterworts, and the Fly-spotted Orchis.

\section{LARGE PURPLE ASTER}

Aster conspicuus. Composite Family

Stems: stout, rigid. Leaves: ovate, oblong, acute, serrate, veiny. Flowers: in numerous corymbosely cymose heads; involucre broadly campanulate, its bracts in several series; rays in a single series, not very numerous; disk-flowers tubular, perfect.

In August or September the mountain meadows and forests teem with many of these flowers, for then

"Everywhere the purple asters nod, And bend, and wave, and flit."

They are the pretty heralds of Autumn, some of them tall, handsome, and stately, like the Large Purple Aster; some 
PLATE LVII

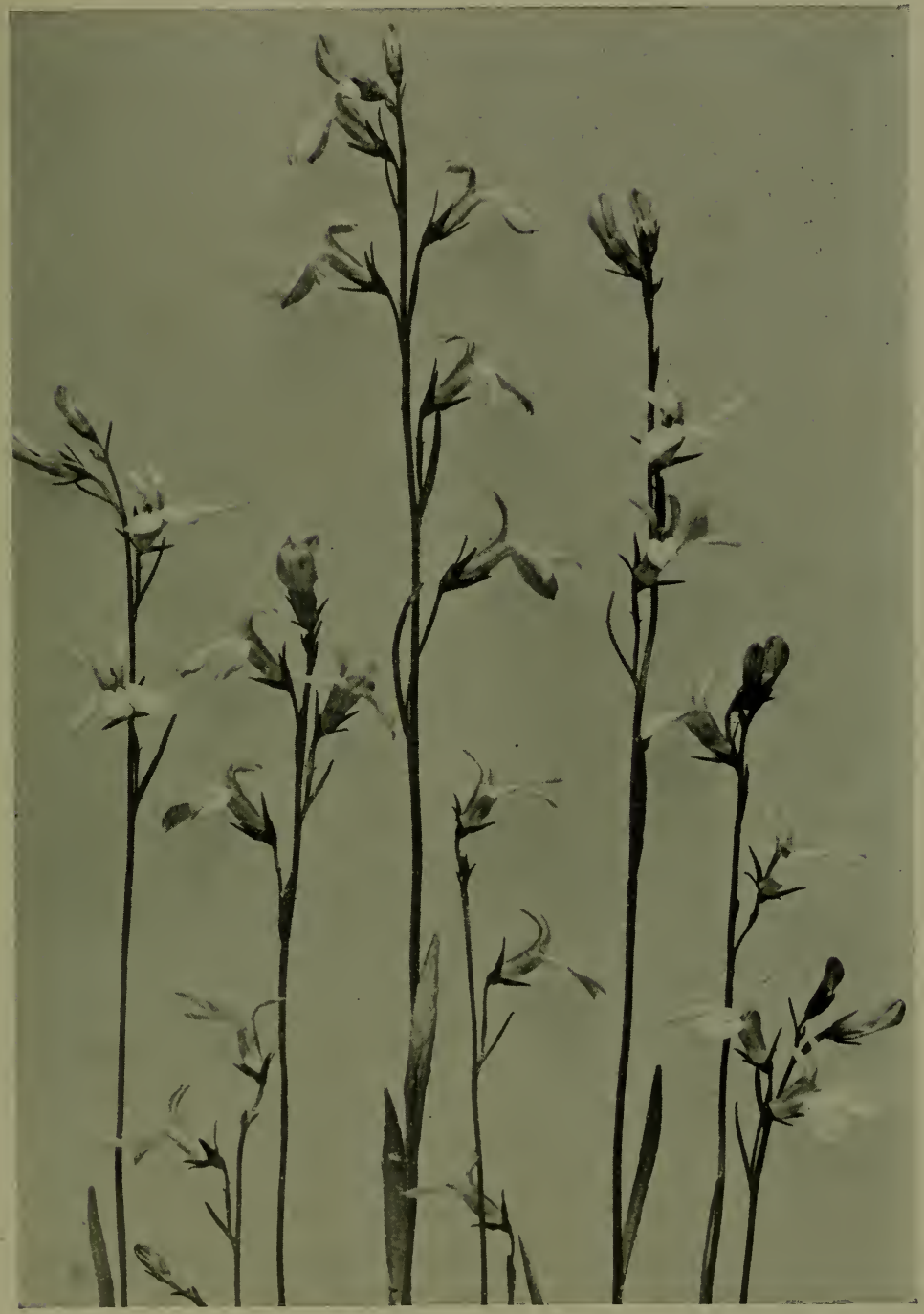

Brook Lobelia

(Lobclia Kalmii) 
quite small, some big and branching, and others again straight and slender, but all tending to glorify the earth. The Aster conspicuus is the largest and handsomest of all its tribe, as its name suggests. It is very branching and has large leaves that are sharply toothed; while the involucre, or green cup which holds the flower, is curiously formed by several series of tiny narrow-pointed bracts, which stand out horizontally and give it a fringed appearance. The rays of this Aster are a lovely bright purple, and the disk-flowers in the centre are golden yellow.

Aster Fremonti, or Fremont's Aster, is a very common species. It also has purple rays, but rather brownish-yellow disk-flowers. All the Asters consist of numerous, tiny, tubular disk-flowers crowded together in a close cluster and surrounded by the rays, or ray-flowers, which are strapshaped, the whole being held together in a green cup, or involucre, of bracts. The leaves of Fremont's Aster are quite smooth at the edges.

The Asters are much-prized flowers, because they come to us at a season when the whole world is walking in russet garb along a penitential pathway that leads to winter's prison. Only the Golden-rods and Asters are left to linger through the soft gray days of late autumn, and what could be more beautiful than these blossoms of purple and gold, which, where the sun strikes light with his ruddy lances, bejewel the burnished lustre of bare branches and brown fallen leaves?

Aster frondeus, or Leafy-bracted Aster, is a stoutstemmed erect species, with violet, purple, or white rays. It has many flowers growing on short stalks, which spring out at intervals from the axils of the clasping smoothedged leaves, all the way up the long main stems; and the 
bracts of the green involucre are very conspicuous, especially the outer and lower series, which spread forth horizontally and are almost like tiny leaves. This Aster usually grows near water.

Aster Engelmanni, or Engelmann's Aster, is a rather tall robust plant, of coarse appearance, with clusters of purple flowers, each one growing on its own individual axillary stalk, or else in a terminal cyme.

A common English name for Asters is Michaelmas Daisies, because they bloom at the feast of Saint Michael, according to

\section{"The calendar,}

Faithful through a thousand years

Of the painted race of flowers, Exact to days, exact to hours."

Aster Lindleyanus, or Lindley's Aster, has tall stout stems branched above, thick glabrous leaves, the lower ones cordate at the base, sharply serrate and acute, and the upper ones ovate, nearly entire and sessile. The violet-blue flowers are not numerous, and the ten to twenty rays are a quarter to half an inch long.

Aster lavis, or Smooth Aster, has thick, usually entire, rough-margined leaves, the upper ones sessile and strongly cordate-clasping, the basal and lower ones gradually narrowed into winged petioles. The purple-blue flower heads are numerous, the involucre being campanulate, its bracts rigid acute appressed and imbricated in several series. The rays number fifteen to thirty.

Aster Richardsonii, or Richardson's Aster, is hairy and much branched from the base. The leaves are oblong spatulate and serrate. The violet-purple flower heads are solitary, terminating the branches, and the involucre is broadly 
campanulate, the bracts being narrowly lanceolate with acute loose herbaceous tips.

Aster major, or Great Northern Aster, has tall stems which are leafy to the summit and very hairy. The leaves are lanceolate, partly clasping by a narrowed base, acuminate at the apex, sharply serrate, dark green above and rather paler beneath. The purple flower heads are usually solitary at the ends of short branches. The rays number thirty to forty-five.

Aster ciliomarginatus, or Hairy-margined Aster, has tall round stems tinged with red. The basal leaves are smooth with hairy-fringed margins, serrate, and tapering into wingmargined petioles, the upper leaves are oblong and sessile. The light blue flower heads are few in an open panicle, and the linear involucral bracts are fringed with hairs on the margins.

Aster sibiricus, or Violet Aster, has broadly lanceolate leaves, and solitary violet flowers terminating the corymbiform branches. The involucre is short, its bracts narrowly lanceolate with acute loose herbaceous tips.

\section{BLUE FLEABANE}

\section{Erigeron acris. Composite Family}

Stems: hirsute-pubescent, slender, simple or branched. Leaves: pubescent, entire, the lower ones spatulate, the upper ones oblong, sessile; involucre hemispheric, its bracts linear, hirsute. Flowers: rays numerous, tubular; pistillate flowers filiform; pappus simple, copious.

A very common species of Fleabane, which has numerous small flowers growing in a cluster at the top of each slender stem, and also a few solitary axillary blossoms lower down. The whole plant is hairy, the lower leaves being spatulate and the upper ones oblong, all with smooth perfect margins. 
The Fleabanes differ from the Asters in one very essential particular, namely, that the rays of the former are much narrower and very much more numerous than those of the latter, forming a thick fine fringe round the edge of the flowers. Also the Fleabanes bloom earlier in the season. They are extremely prolific.

Erigeron philadelphicus, or Lavender Fleabane, has a thick, finely cut lavender fringe encircling its yellow disk of tiny tubular florets. The leaves are very clasping and toothed, and the rays often number one hundred and twenty.

Erigeron uniflorus, or Arctic Fleabane, is a tiny dwarf plant, growing from one to six inches high, and found only on the loftiest mountain summits. It has a single slender stem, which is clothed at the base by a small cluster of smooth-margined hairy leaves; a few little narrow leaves also grow higher up. At the top is a solitary purplish flower. The whole plant is very hairy and woolly.

Erigeron lanatus, or Alpine Fleabane, is also a species which grows at great elevations. It has both purple and white flowers, and is covered with a soft, whitish, woolly coating.

Erigeron salsuginosus, or Large Purple Fleabane, is the king of its tribe. It has very large and lovely purple flowers, with big yellow disks and a few small, thick, smooth leaves clinging to its stout downy stems. The rays number from fifty to seventy, and the bracts of the involucre are narrow and spreading. This particular Fleabane is quite unmistakable, for it is much larger and handsomer than any of the other mountain species, and makes the alpine meadows and slopes quite gay during its flowering season, which is in the early autumn. 


\section{PURPLE SAUSSUREA}

Saussurea densa. Composite Family

Stems: rearly smooth with a decumbent base. Leaves: thin, oblong, lanceolate, acuminate, sinuate-dentate. Flowers: several in a corymb.

This plant grows chiefly on stony slopes and in other dry places among the mountains. The dark purple flower heads are quite handsome and grow in a compact terminal corymb.

\section{WAVY-LEAVED THISTLE}

Carduus undulatus. Composite Family

Persistently white-tomentose throughout. Stems: stout, leafy. Leaves: lanceolate in outline, acute, sessile, undulate, lobed, the lobes dentate, triangular, very prickly. Flowers: solitary at the ends of the branches.

This reddish-purple Thistle grows from one to three feet high and is a fine handsome plant with large long leaves, whose edges are wavy and triangularly lobed, the lobes being sharply toothed and very prickly. The big flower-heads grow at the ends of the branches and are surrounded by large involucres of prickly bracts.

Every traveller knows that the Thistle is the national floral emblem of Scotland, and has been ever since that day when a barefoot Danish soldier, stepping inadvertently upon its spines, gave a cry of pain which aroused the sleeping Scottish camp and saved Scotland. The motto which Scotsmen affix to this flower is "Ncmo me impune lacessit" (No one touches me with impunity), or in the vernacular, "Ye maun't meddle wi' me." And assuredly we are quite content to leave it alone in its prickly glory, only pausing a moment in passing to admire its fine richly coloured flowers. 


\section{CHICORY}

\section{Cichorium Intybus. Composite Family}

Stems: branching. Leaves: stem-leaves oblong or lanceolate, partly clasping, the lower spatulate. Flowers: sessile, axillary or terminal. Fruit: achenes striate, pappus of numerous small chaffy scales, forming a short crown. Not indigenous.

The Chicory, or Succory, is a common flower, whose long, deep tap-root is dried, roasted, ground and used so much as an adulterant of coffee. The name Chicory is of Arabian origin, the French call a salad made of its blanched leaves "Barbe de Capucin," and children look for the "Blue Sailors" by the roadside, while Emerson has written of

$$
\text { "Succory to match the sky." }
$$

The grey-blue, and sometimes pinkish or white flowers, grow close against the tall branching stalks, sometimes singly and sometimes in clusters, and are composed only of ray flowers, five-toothed at the edge and set in a flat green receptacle. The base leaves are spatulate and usually strongly incised, the upper ones being reduced to oblong bracts. This is an introduced plant. 



\section{WILD FLOWERS OF THE NORTH AMERICAN MOUNTAINS}

\section{SECTION VII}

\section{YELLOW TO ORANGE FLOWERS}





\section{SECTION VII \\ YELLOW TO ORANGE FLOWERS}

\section{WESTERN SKUNK CABBAGE}

Lysichiton kamtschatcense. Arum Family

Rootstock: horizontal, thick. Leaves: oblong, acute. Flowers: perfect, crowded, covering the spadix, spathe with a broad acute blade narrowed to a sheathing petiole. Fruit: fleshy berries immersed in the spongy axis of the spadix, seeds large.

This evil-smelling marsh herb has such handsome foliage and glorious lemon-yellow spathes enveloping the fleshy spikes of tiny flowers, that it always attracts the eye of the traveller. It resembles a huge Arum Lily, with the difference that in the Western Skunk Cabbage the spathe is erect and pointed, extends somewhat over the flower spike, and is not curled back at the top, as in the case of the white Arum Lily.

\section{MOUNTAIN LILY}

\section{Lilium montanum. Lily Family}

Bulb composed of narrow, jointed, fleshy scales. Stems: tall, leafy. Leaves: lanceolate, acute at both ends, all verticillate, the margins finely roughened. Flowers: erect, perianth reddish-orange, of six spreading segments, each one gradually narrowed into a claw, purplespotted below.

Lilies grow in many climes and are of divers hues. White and yellow, orange and red, tall and stately, they flourish conspicuously in the valleys and on the mountain tops, beneath blazing tropical suns and close beside the eternal snows. 
PLATE LVIII

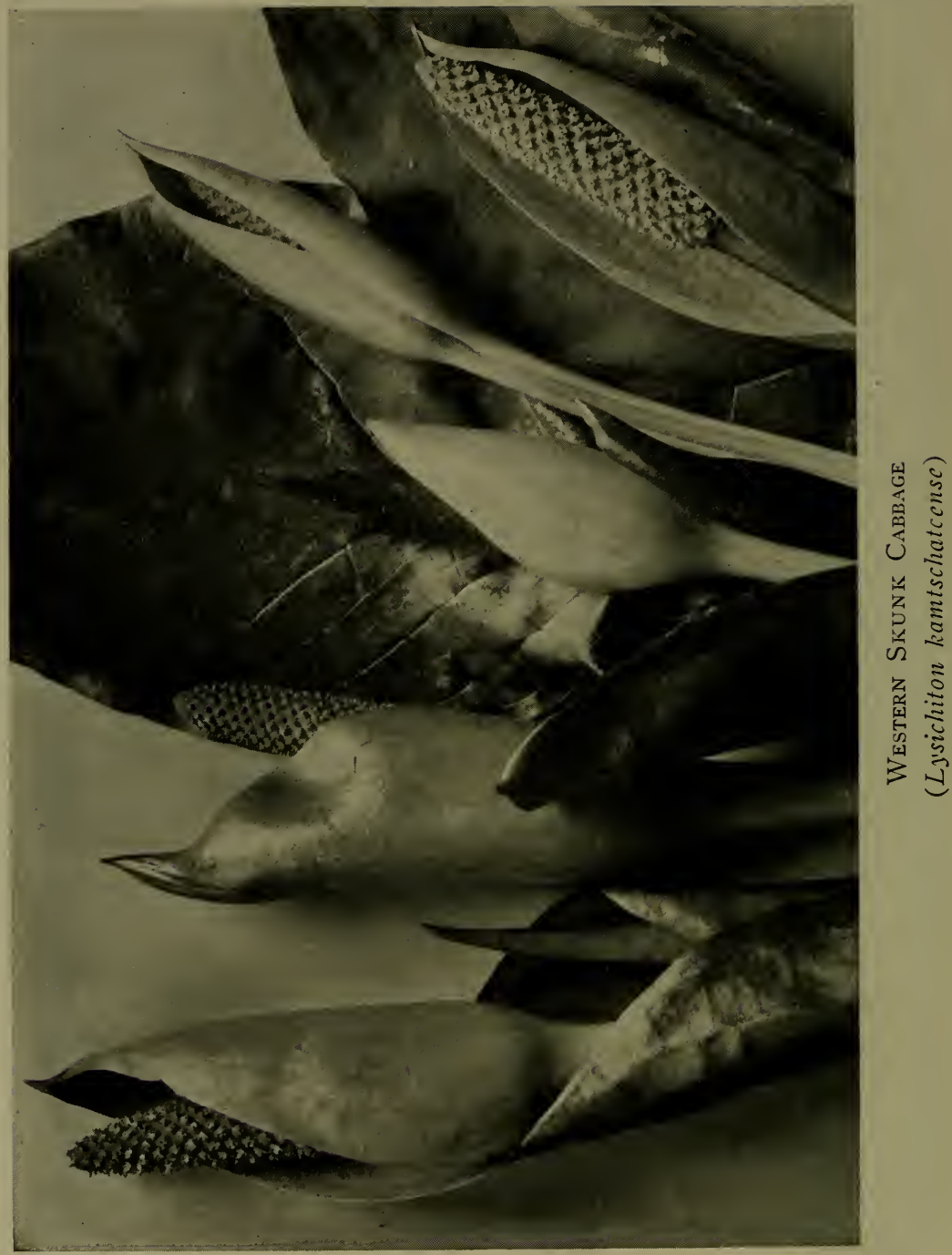


The Mountain Lily is one of the handsomest of the alpine flowers, and early in July its red-tinted tawny bells render the woods attractively gay. As if conscious of their glory, the large bright blossoms grow erect on tall stems, round which circling clusters of dark green narrow-pointed leaves are set at intervals; the outer surface of the segments is pale orange, while the open bells are of a vivid reddish hue within, and spotted with purplish-brown. Large anthers crown the six long stamens, and the stigma is threelobed.

This Lily does not fear the drought of long summer days, but grows in stately splendour in the driest thickets. It has assumed a gorgeous garb of flaming orange in order to attract those insects that pollenize its flowers; for while the brilliant colour quickly attracts the bees, the purplish spots and lines unerringly point out to them the most direct route to their desired goal, namely, those nectar grooves which lie at the base of each segment.

Truly was it said that " even Solomon in all his glory was not arrayed like one of these"; for the wild orange-red Mountain Lilies shine with a beauty unequalled in the alpine forests.

\section{WESTERN LILY}

\section{Lilium columbianum. Lily Family}

Bulb, with lanceolate, acute, closely appressed scales. Stems: slender. Leaves: in whorls, scattered above and below, narrowly lanceolate, sharply acuminate, thin, glabrous. Flowers: racemose, or in whorls on stout pedicels, six segments of the perianth revolute.

This Vvestern Lily somewhat resembles the Turk's-cap Lily, for its head is drooped and its floral leaves are revolute, or rolled backwards, being bright orange in colour and thickly spotted with purple on the inside. It has six very 


\section{PLATE LIX}

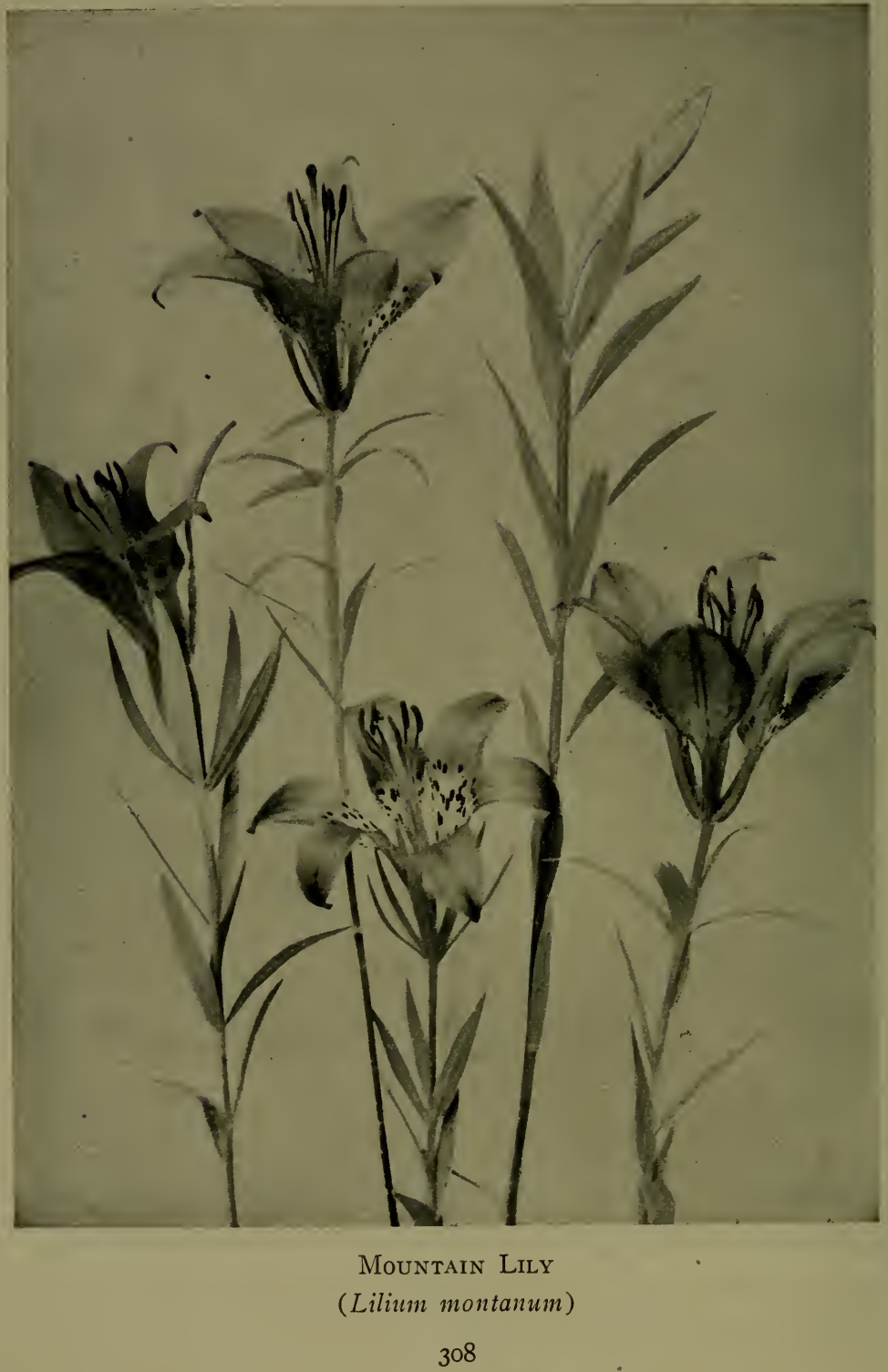


long stamens, which terminate in large, oblong, yellow anthers; the segments of the perianth are not clawed, as in the Mountain Lily, but are joined together at the base, forming a perfect bell.

As in all the species of Lilium, the bulb consists of a large number of overlapping scales, which are merely thickened, undeveloped leaves, serving as storehouses for the starchy wealth of the plant. Any one of these scales, if separated from the mass, will develop into a tiny bulb.

Very radiant are these clustered Western Lilies, which burn like torches in the green alpine meadows at

"The time when lilies blow,

And clouds are highest in the air."

\section{YELLOW FRITILLARY}

\section{Fritillaria pudica. Lily Family}

Stems: simple, leafy. Leaves: linear, scattered or verticillate. Flowers: usually solitary, nodding, narrow-campanulate. Fruit: capsule membranaceous, oblong to subglobose, seeds numerous, horizontal, flat, in two rows in each cell.

The Fritillary is too well known to require much description, and this mountain species is particularly attractive with its large orange-yellow, nodding flowers, that are sometimes purplish, growing solitary at the top of the leafy stems, which spring from a scaly bulb. The leaves are flat, long and narrow, and the segments of the narrow-campanulate perianth are oblong-spatulate, obtuse and somewhat spreading. This is one of the earliest flowers to bloom in the spring.

\section{YELLOW ADDER'S TONGUE}

\section{Erythronium grandiflorum. Lily Family}

Stems: scape stout. Leaves: broadly lanceolate, acute, pale green. Flowers: one to several in a terminal raceme; perianth broadly funnel- 
form, of six distinct segments: outer ones lanceolate, obtuse; inner ones narrower, acuminate, with four stout hyaline teeth at base, all strongly revolute.

A lovely yellow flower, frequently called "Snow Lily," from the fact that it grows in such close proximity to the great alpine nérés. "Dog-tooth Violet" is yet another name for this plant, and refers more particularly to the white bulb, which is supposed to resemble the canine teeth of a dog.

Adder's Tongue probably refers to the pointed anthers, which are six in number and extremely conspicuous; but "Snow Lily" is by far the more appropriate designation for a blossom which appears at the edge of the avalanches and follows the retreating line of the snow when the warm spring sunshine melts the great white masses in the valleys and sets the flowers free. At high altitudes you will often see numbers of pale green pointed leaves forcing their way up through the soft covering, and myriads of bright yellow blossoms rising but a few inches above the thin carpet of frozen crystals. From between two or three of these large leaves (somewhat like those of the Lily-of-the-Valley) springs the slender stalk, which terminates in a single bud, or occasionally in a small raceme of drooping golden bells. Soon the six pointed segments of the perianth unfold and expand, gradually rolling backwards until they become completely recurved, leaving the whole length of the stamens exposed. These segments, or floral leaves, are an exquisite shade of yellow, softening to cream colour at the base in the centre. The style bears at its summit a deeply three-cleft stigma, each division thereof being also recurved.

Great colonies of Yellow Adder's Tongues grow in the mountains, where their faint fragrance scents the air with a 


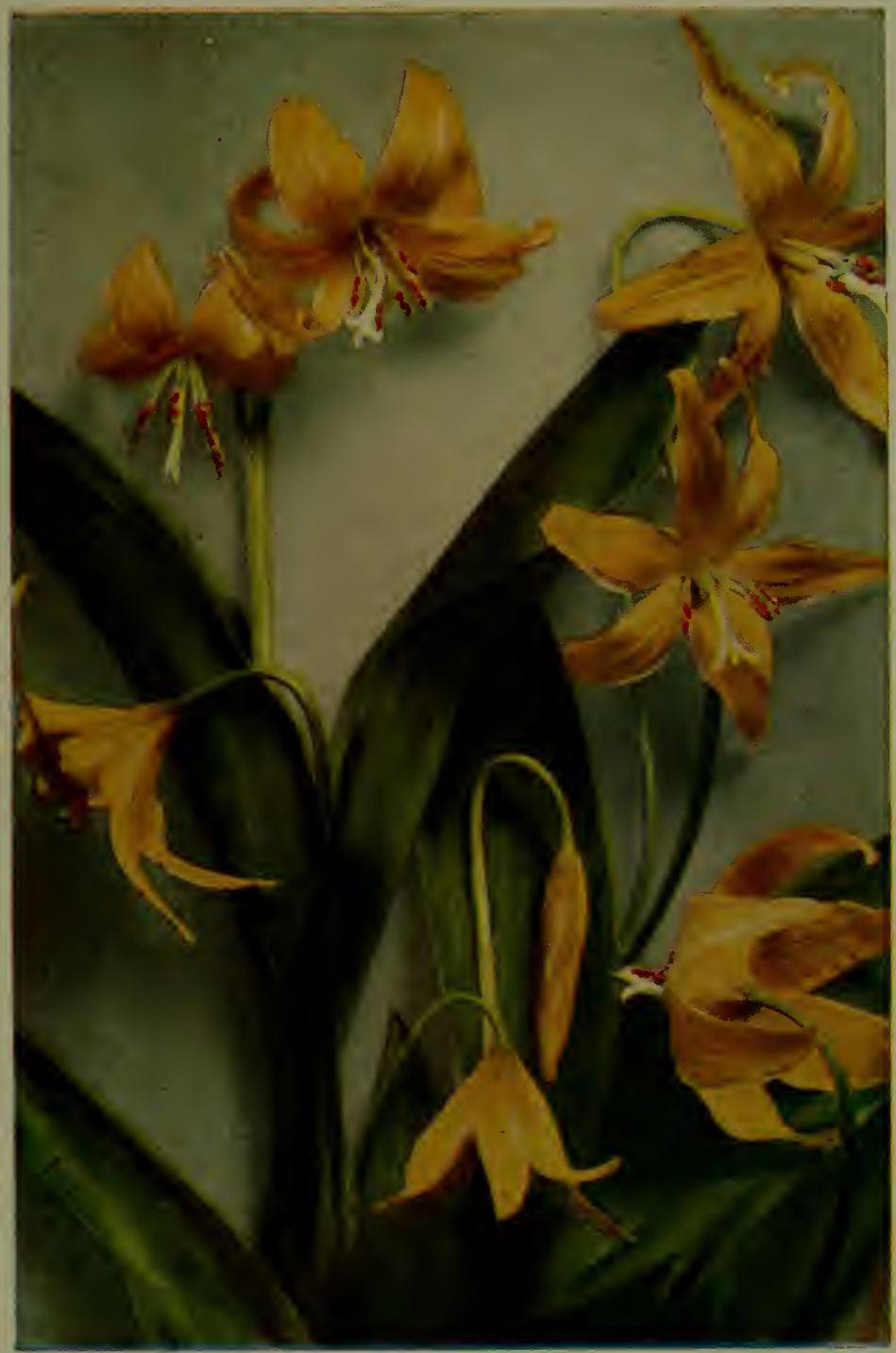

Yellow Adder's Tongue

(Erythronium grandiflorum) 

delicious perfume. Late at evening, when beneath the starsown purple of the sky you return from making some alpine ascent, the pure flames of these wild Lilies gleam in their leafy setting with a pale golden light, and illuminate the green brink of your path; and when the noonday is glorified, and the flag of the sun floats top-masted in the skies, then

\section{"You see gems in yellow}

Nodding, each one, to his fellow,

Strewing all the country lanes

With divinely builded fanes,

Where the benisons are breathed but never spoken."

Ery'thronium grandiflorum z'ar. parviflorum, or Small Yellow Adder's Tongue, is not so tall as the preceding species, and has rather narrower leaves and smaller flowers.

\section{YELLOW BLUE-EYED GRASS}

Sisyrinchium californicum. Iris Family

Stems: scapes broadly winged. Leaves: much shorter than the scapes, bracts of the spathe more or less unequal, the longer about equalling the pedicels. Flowers: bright yellow, segments of the perianth obtuse or acutish, style cleft to below the middle. Fruit: capsule obovate-oblong.

This plant has a name which is rather an anomaly. The tall, broadly-winged scapes are two-edged, and have a solitary, sessile spathe, while the leaves are shortish and narrow. The bright yellow flowers are extremely attractive.

\section{LARGE YELLOW LADY'S SLIPPER}

\section{Cypripedium pubcscens. Orchid Family}

Stems: leafy. Leaves: oval or elliptic, acute. Flowers: sepals ovate-lanceolate, longer than the lip, yellowish-green striped with purple; petals very narrow and twisted, lip much inflated, bright yellow with greenish-purple lines, a tuft of white jointed hairs at the top of the interior; stamen sterile, triangular; stigma thick, incurved. 
In the dry sun-warmed forests, where the birds trill their sweet antiphons and the smooth surface of the pools reflects with steadfast truth the cone-laden branches of fir and pine and the fleecy clouds that float across the azure sky,- there, unafraid, rejoicing in its weird, almost unearthly beauty, the Large Yellow Lady's Slipper flaunts its gaudy flowers.

At the first sight of these exquisite orchids, which also grow on the open arid moraines close to the glaciers, you catch your breath, and a thrill runs through all your veins; there they stand, golden-bright, surrounded by a halo of romance and mystery.

There is little need to describe this Cypripedium, for its showy inflated sac, flanked by long spiral petals and purplishgreen sepals, distinguishes it at once, even to the unpractised eye. The leaves of the Large Yellow Lady's Slipper grow alternately on the slender hairy stems, and are large, long-shaped, pointed, many-nerved, and plaited. The name Cypripedium is derived from the Greek, and means Venus's sock or buskin.

Cypripedium parifforum, or Small Yellow Lady's Slipper, much resembles the preceding species, but may be easily distinguished by means of its smaller flowers, the inflated sacs of which are of a much deeper, richer shade of yellow, and are often marked with reddish-purple spots and lines, and also by its wider oval-shaped leaves and thicker stems.

In July, that exquisite month which lies within the very heart of summer, should you wander amid the mountains when dawn trumpets forth the glittering rise of day, then pause beside some sluggish alpine stream, which lies coiled in sleepy curves, for there, far removed from the haunts of men, you may be fortunate enough to find the fragrant little Cypripedium parviflorum. 
Unlike the Large species, this Small Yellow Lady's Slipper usually seeks the seclusion of the hazy hollows and the moist misty woods. Rightly have these lovely sweetscented flowers been proclaimed

“Golden slippers meet for fairies' feet."

\section{YELLOW POND LILY}

Nymphaa polysepala. Water-Lily Family

Leaves: all floating, eight to fourteen inches in diameter, broad-ovate, thick, deeply cordate, on stout half-cylindrical petioles. Flowers: two to five inches in diameter; sepals eight to twelve, unequal, concave and roundish; petals eleven to eighteen, dilated, truncate, shorter than the stamens. Fruit: globose, indehiscent.

This Pond Lily has numerous rounded concave sepals, which are of a deep orange-yellow colour inside and usually streaked and blotched with purple-red on the outside, and assume the function of petals; for the real petals of this plant, though very numerous, are inconspicuous and resemble the stamens, being thick, short, and fleshy.

The Yellow Pond Lily is not so beautiful as its cousin, the White Water-lily, yet the golden-hued mountain species is very fragrant; it has handsome floating foliage, and flowers which poets have not disdained to praise.

Longfellow described Hiawatha's canoe as floating

"Upon the river

Like a yellow leaf in autumn,

Like a yellow water-lily."

This Pond Lily grows in still waters and slow streams, where, springing from thick, horizontal, deeply submerged rootstocks, the long stalks, which are flattened on the inner side and rounded on the outer side, uphold the gleaming floral cups. In many an alpine lake 
"The bright Nymphaa loves to lave,

And spreads her golden orbs along the dimpling wave."

Nymphca signifies " a water-nymph," and the botanical family to which this Yellow Pond Lily belongs is called in the Latin Nymphaacec, or Water-lily Family.

\section{MEADOW BUTTERCUP}

Ranunculus acris. Crowfoot Family

Stems: erect, hairy, branched above, roots fibrous. Leaves: basal ones tufted, petioled, three-to-seven parted, the divisions sessile and cleft into numerous narrow acute lobes; upper leaves three-parted. Flowers: numerous; petals five, yellow, conspicuous. Not indigenous.

Every child knows and loves the bright yellow flowers of the common Buttercup. Every child has sung of

"Buttercups and daisies, And all the pretty flowers, Growing in the sunshine

To tell of happy hours."

Yet the Ramunculus acris is the enemy of the farmer. Cattle will not eat of its acrid leaves, and even the hands of man are frequently scarred and blistered by the caustic juices contained in the stalks and leaves of this plant. High up in the mountains, however, where the

\section{"Buds of yellow hue}

Do paint the meadows with delight,"

we welcome these brilliant Buttercups; there they can harm no one, but only please the eye with their finely dissected foliage and tall-stemed golden flowers.

If you cut vertically through the middle of this Ramunculus, you will find that its receptacle is a long cone, from which the five green sepals, the five yellow petals, the numerous stamens, and the carpels all spread out successively. 
Care must be taken not to confuse the Ranunculi with the Potentillas, which latter belong to the Rose Family and are also described in this Section, for the blossoms of the two plants somewhat resemble each other, though a close inspection and comparison of them, together with their stems and leaves, will always serve to plainly demonstrate at once the differences which exist between them. One point of variance which may be specially noted is that the Ranunculus usually has simple lobed, or divided or dissected leaves, whereas the Potentilla usually has compound leaves; that is to say, the Ramunculus has, in most cases, leaves that are much cut up and lobed, but the Potentilla, as a rule, has leaves formed of several entirely separate leaflets. This distinction is, however, not arbitrary, though it exists in the majority of cases. Also each petal of the Ranunculus has a tiny pit, or spot, covered by a scale, on the inside of the claw, near the base. This spot is absent in all the Potentillas. The Meadow Buttercup has fibrous roots. This is an introduced plant.

Ranunculus Macounii, or Macoun's Buttercup, is an erect, very hairy plant, growing from one to two feet high, and has yellow flowers.

Ranunculus Eschscholtaii, or Snow Buttercup, grows at very high altitudes, close to the snow and always near water. A cluster of much-divided leaves grows up from the base of the plant on long slender stems, and half-way up the flower-stalk there is a circle of narrowly lobed leaves, and also, frequently, a single bud. The large yellowish calyx, which is covered with brown hairs on the outside, gives the flower almost a double appearance. The head of the fruit is oblong.

Ramunculus Cymbalaria, or Creeping Crowfoot, as iț 
name denotes, is a small creeping plant, having numerous runners which root at the joints, whence spring up little clusters of leaves. The flowers are yellow and very tiny.

Ranunculus aquatilis var. capillaceus, or Water Crowfoot, has tiny white and yellow flowers. The fine threadlike leaves are entirely submerged under the surface of the alpine lakes and pools, where the plant grows abundantly, while the broader three-lobed leaves float upon the face of the waters. These thread-like leaves are common to several kinds of aquatic plants, and such minute division enables them without a large expenditure of material to expose a large surface to the carbonic acid gas dissolved in the water.

Ranunculus reptans, or Creeping Spearwort, has small yellow flowers with from four to seven petals, trailing stems that root at the joints, and extremely narrow grass-like leaves. The flowers are borne in the axils of the prostrate creeping stems.

Ranunculus repens, or Yellow Crowfoot, is a hairy plant, which spreads by means of its runners and forms large patches upon the ground; it has leaves which are divided into three parts, each one of which is lobed and toothed. The flower-stalk is grooved, the sepals are widely spread, and the petals are half-erect. This is an introduced plant.

Ranunculus pygmaus, or Pigmy Buttercup, is a very tiny plant growing only one to three inches high on the alpine summits. It has deeply three to five lobed basal leaves with slender stalks, and similar sessile stem leaves. The petals of the wee yellow flowers slightly exceed the sepals and the fruit heads are short-oblong. 


\section{MARSH-MARIGOLD}

\section{Caltha palustris. Crowfoot Family}

Stems: erect, one-to-two flowered, the lower flower subtended by a petaloid lanceolate bract. Leaves: roundish to oblong-cordate, longer than wide, irregularly crenate-toothed. Flowers: yellow; sepals petaloid, lanceolate, acute; petals none; stamens and pistils numerous.

This is a splendid-looking marsh plant, with large roundish glossy leaves of a deep bright green, and fine yellow blossoms that are tinged with purple on the outside. It resembles a large Buttercup. The name Marigold is a corruption of "Mary's gold," for this flower was dedicated to the Holy Virgin in the Middle Ages, a fact to which Shakespeare refers in Cymbcline, when he causes the musicians to $\operatorname{sing}$ :

"Hark, hark! the lark at heaven's gate sings, And Phcebus 'gins arise, His steeds to water at those springs

On chalic'd flowers that lies;

And winking Mary-buds begin

To ope their golden eyes."

The Marsh-marigold has no petals, but its five or more petaloid sepals do duty instead. The leaves of this extremely succulent plant are mostly heart-shaped at the base, and just below the flower is borne a petal-like long-shaped bract.

Ofttimes amid the mountains you will see flat moist meadows literally ablaze with these showy blossoms, which turn the marshes into a veritable Field of the Cloth of Gold.

\section{YELLOW COLUMBINE}

Aquilegia flavescens. Crowfoot Family

Stems: smooth. Leaves: ternate; leaflets round-cordate, threeparted, the segments coarsely toothed. Flowers: yellow, pendulous; 


\section{Yellow to Orange Flowers}

petals five, with short spreading lips, and produced backwards into long tubular spurs; sepals reflexed, longer than the spurs.

This Columbine grows at great altitudes, and may be found amongst the rocks at a height of 8000 feet, where the soil is so light and sparse that there seems to be no foothold for any vegetation at all, much less for such tall and graceful plants as these Aquilegias, which stand from one to three feet high and bear abundant blossoms of pale yellow, pendent on their brittle stalks.

The foliage of the Yellow Columbine is much smaller and more delicate than that of $A$. formosa; but it is equally dark green above and pale green beneath. No prettier sight can be seen than clusters of these wild elfin flowers growing at the edge of some barren cliff, their fragile loveliness shining against a sombre background of stony walls, from the height of whose overhanging ledges the blossoms nod down at the traveller, as they sway and swing at the bidding of the breeze.

\section{ROCKY MOUNTAIN GRAPE}

Berberis repens. Barberry Family

A low glabrous shrub. Leaves: petioled, pinnate, the leaflets three to seven, ovate, obtuse, truncate at the base, sessile, thick, finely retriculated, dentate with spine-bearing teeth. Flowers: in short racemes, the clusters terminal and axillary, many-flowered, yellow. Fruit: a globose dark blue berry.

This shrub, which is exceedingly ornamental, has yellow wood and bright green foliage, which turns to a lovely reddish colour in the autumn. The tiny vivid yellow flowers grow in short thick clusters; they have six bracted sepals, with six petals opposite them, also six stamens.

Berberis aquifolium, or Oregon Grape, is a taller shrub than the preceding species, with five to nine oblong-ovate, 
pointed, pinnate leaves, which are spiny-toothed and very green and shining on the upper surface. The bud scales are triangular, and the tiny yellow flowers grow in terminal and axillary clusters.

\section{ARCTIC POPPY \\ Papaver alpinum. Poppy Family}

Stems: scape erect, hirsute. Leaves: all basal, pinnately lobed or cleft, the lobes linear, acute. Flowers: solitary. Fruit: capsule obovoid, densely beset with erect bristly hairs.

This is quite an alpine-arctic plant and grows only on the high summits. It has a flower varying in colour from yellow to reddish-orange, which grows on the top of a slender, very erect stalk, and is formed like a common Poppy, but has only four petals. All the leaves grow at the base of the plant and are long-shaped and lobed.

\section{GOLDEN CORYDALIS}

Corydalis aurea. Fumitory Family

Commonly low and spreading. Leaves: finely dissected into oblongobovate segments. Flowers: in short spicate racemes; corolla tubular, irregular; petals four, one of the outer pair spurred at the base, the interior ones narrow, keeled on the back; spur half the length of the body of the corolla. Fruit: pods spreading.

This plant generally grows low upon the ground, the very finely dissected foliage spreading out into large patches that are gemmed by the clusters of golden-yellow flowers, whose form at once suggests that of the Wild Bleeding-heart. When the ripe pods split open they disclose and scatter numerous bright shining seeds. 


\section{GOLDEN WHITLOW GRASS}

\section{Draba aurea. Mustard Family}

Stems: branching, pubescent, leafy to the inflorescence. Leaves: basal ones in tufts, spatulate, obtuse, slightly dentate; stem-leaves oblong, acute. Flowers: yellow, petals twice the length of the calyx, entire. Fruit: pods acute, at length, slightly twisted.

A plant that resembles a Treacle Mustard, but is much smaller and has a rosulate tuft of leaves at the base. Tiny single leaves also grow up on the branching stems, and the little deep yellow flowers grow in close clusters.

Draba alpina, or Alpine Whitlow Grass, is a tiny species found at extremely high altitudes. The leaves are all basal and grow in a dense tuft, while the tiny clusters of little yellow flowers are set on the top of short naked stalks. The whole plant is hairy and seldom exceeds four inches in height.

Draba nivalis, or Arctic Whitlow Grass, has numerous slender matted branches, and lance-shaped hairy leaves which have a strongly marked mid-nerve. The flowers are yellow and inconspicuous, and the whole plant is covered with tiny hairs and a whitish bloom. It grows at high altitudes.

Draba glacialis, or Pale Yellow Whitlow Grass, grows on the summits of many mountains. It has strongly keeled leaves and the petals are pale yellow, becoming darker at the base.

\section{BLADDER-POD}

Physaria didymocarpa. Mustard Family

Stems: decumbent or ascending, slender, simple. Leaves: spatulate, the basal ones obtuse, entire, narrowed inta margined petioles; stemleaves nearly sessile, acute, much smaller. Flowers: yellow, in ter- 
PLATE LX

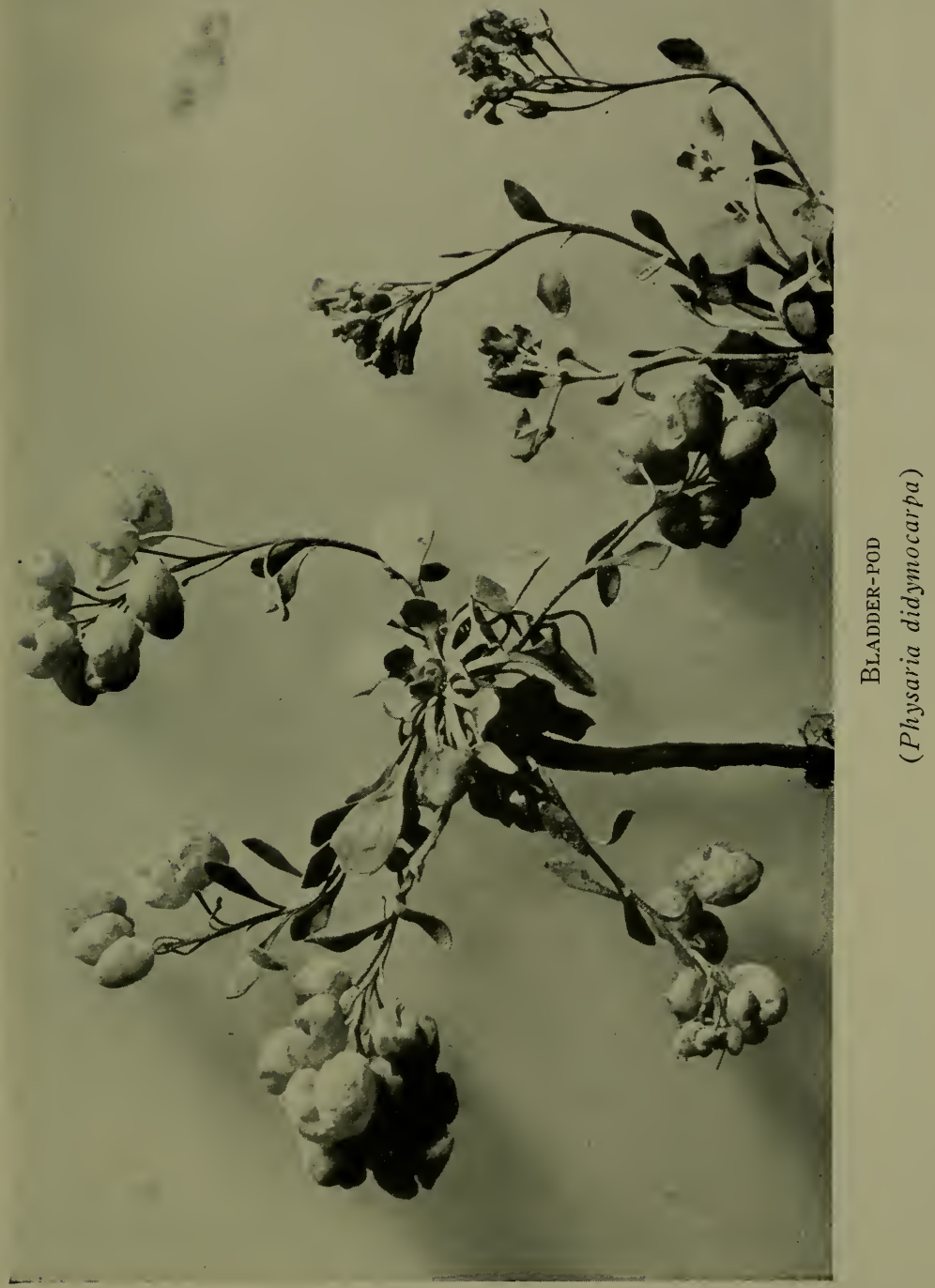


minal racemes. Fruit: pods didymous, variable, with large, strongly inflated cavities, emarginate at base and summit.

A most curious and interesting plant, which grows on high rocky slopes and forms patches upon the ground by means of its rosettes of pale green leaves and decumbent stems. The little yellow flowers are cruciform and inconspicuous, and grow in clusters at the ends of the long slender stalks which spring out from below the central rosettes of leaves, while an irregular circle of outer leaves grows beyond them again. It is the large inflated pods, of a delicate gray-green hue, which give this plant its common name and constitute its greatest attraction. They are really exquisitely quaint, and so unusual as to always attract the notice of the passing traveller. The leaves are spatulate and small. The name Physaria is derived from the Greek, signifying " bellows," and refers to the inflated fruit.

\section{NESLIA}

Neslia paniculata. Mustard Family

Stems: slender, branched above. Leaves: lanceolate, acute, entire, sagittate-clasping at the base. Flowers: racemose. Fruit: silicles small, globose, wingless, reticulated, indehiscent. Not indigenous.

This herb is usually one to two feet high and has lanceshaped leaves with even margins, which are arrow-headshaped and clasping at the base, and grow all up the slender stems. The small ascending yellow flowers form elongated racemes. This is an introduced plant.

\section{HERB OF ST. BARBARA}

Brassica Sinapistrum. Mustard Family

Stems: erect, hispid, with scattered stiff hairs. Leaves: oval, coarsely dentate, the basal ones pinnatifid. Flowers: showy, yellow, in elongated 
racemes. Fruit: the siliques elongated, sessile, tipped with a flattened conic beak. Not indigenous.

A handsome species bearing showy yellow flowers in terminal racemes, and having large oval leaves that are very coarsely toothed, rough to the touch, and conspicuously veined. The basal leaves are lobed. Like all the Mustards, it has four cruciform petals. This is an introduced plant.

\section{HARTWEG'S TANSY MUSTARD}

Sisymbrium Hartwegianum. Mustard Family

Stems: slender. Leaves: pinnate; leaflets lanceolate, obtuse and acutely toothed. Flowers: small, yellow. Fruit: the siliques erect on ascending pedicels, linear, elongated.

A coarse uninteresting plant, with pinnately cut leaves, the tiny leaflets being sharply toothed. The flowers are small and yellow and the pods long and narrow.

Sisymbrium altissimum, or Tall Hedge Mustard, has tall freely-branching stems and lower leaves which are runcinate-pinnatifid, the narrow lobes often auriculate, and smaller, very deeply cut upper leaves. The pale yellow flowers are inconspicuous. The pods are rigid, very long, divergent and hardly thicker than the short pedicels. This is an introduced plant.

Sisymbrium canescens, or Pale Tansy Mustard, is a softhairy species with long deeply cut leaves growing out almost at right angles from the stem; very small yellowish flowers and pods in long racemes.

Sisymbrium incisum, or Western Tansy Mustard, is a similar plant to the Pale Tansy Mustard, but is greener and less hairy, and has longer more slender pods and one-ranked seeds. The leaves have not such a fringed appearance as those of Sisymbrium canescens. 


\section{TREACLE MUSTARD}

\section{Erysimum parviforum. Mustard Family}

Stems: erect, simple. Leaves: oblanceolate or linear, obtuse, entire or dentate, the upper sessile, the lower slender-petioled. Flowers: pale yellow. Fruit: the siliques elongated, linear, four-angled, valves strongly keeled by a prominent mid-vein.

This common Treacle Mustard has very small pale yellow flowers and rather whitish leaves, which latter grow in a tuft at the base of the plant and also alternately all the way up the stiff erect stems. The flowers have four tiny green sepals and four yellow petals, which latter are cruciate, or set in the form of a cross. The Treacle Mustard belongs to the Cruciferc, or Mustard Family, all of whose members have four cruciform petals.

\section{STONECROP}

Sedum stenopetalum. Orpine Family

Flowering branches erect. Leaves: alternate, crowded, but scarcely imbricated except on the sterile shoots, sessile, linear, entire. Flowers: in a three-to-seven forked cyme, compact; petals narrowly lanceolate, very acute, much exceeding the calyx-lobes.

This plant is well named Sedum, from sedere "to sit," for it sits very happily, and in lowly fashion, upon the bleak bald hills at high altitudes. It is a most uncanny plant. The tiny, pale green, juicy leaves, crowded on the thick short stems, are, like human flesh, easily bruised; and each of the bright yellow flowers, which grow in dense clusters, has four or five narrow pointed petals. There are ten stamens, the alternate ones being attached to the petals. The five erect carpels are tipped with long conspicuous and divergent styles, crowned by fat stigmas.

The smooth clammy foliage of the Stonecrop reminds the 
traveller forcibly of the narrow gap which lies between the Animal and the Vegetable Kingdoms, for the touch of its fleshy leaves is most repulsive, resembling that of some cold moist body. Fortunately, however, it is redeemed from being entirely objectionable by the twinkling little golden blossoms, which are as healthy and natural in their appearance as the foliage is the very reverse.

"Flower in the crannied wall,

I pluck you out of the crannies.

I hold you here, root and all, in my hand,

Little flower - but if I could understand

What you are, root and all, and all in all,

I should know what God and man is."

"No deeper thought was ever uttered by poet," says John Fiske, in his beautiful work, Through Nature to God; " for in this world of plants, which, with its magician, chlorophyll, conjuring with sunbeams, is ceaselessly at work bringing life out of death - in this quiet vegetable world we may find the elementary principles of all life in almost visible operation."

Care must be taken not to confuse the Yellow Saxifrage with the Stonecrop. The former has tiny, thin, ordinary leaves, while the latter has leaves that are thick, fleshy, and very juicy. This peculiar foliage of the Stonecrop enables it to retain a quantity of moisture during the dry season, an attribute which proves extremely useful, since it grows in crevices and crannies between the rocks, where the sparse dry soil affords little or no sustenance to the roots; hence its ability to imbibe and retain moisture through its leaves renders it fit to flourish on these sandy and stony slopes. 


\section{YELLOW SAXIFRAGE}

Saxifraga aizoides. Saxifrage Family

Stems: leafy. Leaves: alternate, linear, thick, fleshy, mucronatetipped, narrowed at the base, sessile, the margins sparingly ciliate. Flowers: several, corymbose; petals five, oblong, yellow, usually spotted with orange; calyx five-lobed, base of the capsule adnate to the calyx; stamens ten, inserted with the petals. Fruit: ovary two-celled, twolobed at the summit; styles short; stigmas capitate.

This Yellow Saxifrage grows among the wet rocks at high altitudes. It has slender stems, adorned with alternate leaves, which are long and narrow and edged with a few fine hairs. The flowers grow erect and open out very wide, their petals being usually spotted with orange. The ten stamens are conspicuous, and so is the large two-celled ovary, while the styles are short and tipped with roundish stigmas. This plant grows in dense tufted clusters from two to six inches high, and may be found in the most sunforsaken crannies, where the icy breezes blow across the snow-fields.

\section{GOLDEN SAXIFRAGE}

Chrysosplenium tetrandrum. Saxifrage Family

Stems: erect, branched above. Leaves: alternate, reniform-cordate, doubly crenate or somewhat lobed. Flowers: corymbose, axillary Fruit: capsule membranous, short, inversely cordate.

A marsh plant, or growing in the moist shade, from two to six inches high with alternate rounded blunt-toothed leaves, and orange-yellow flowers that usually have four calyx lobes, coloured within, the four to eight stamens being inserted on the margin of a disk. 


\section{CREEPING SIBBALDIA}

Sibbaldia procumbens. Saxifrage Family

Stems: woody, decumbent or creeping. Leaves: three-foliolate, leaflets obovate, cuneate at the base, three to five toothed at the apex. Flowers: numerous, petals oblong, very small, calyx-lobes oblongovate, longer and broader than the bractlets.

This depressed shrubby plant is found as high as ten thousand feet. It has three-foliolate leaves, the segments of which are wedge-shaped and three-toothed at the apex. The greenish-yellow flowers have very small petals and large broad calyx lobes with pointed tips.

\section{SILVER WEED}

Potentilla Anserina. Rose Family

Stems: tufted, spreading by slender runners. Leaves: petioled, pinnate, leaflets seven to twenty-five, oblong, oblanceolate, obtuse, the lower generally smaller, sharply serrate, smooth above, silky-pubescent below. Flowers: petals broadly oval, entire, exceeding the ovate acute calyxlobes and oval bractlets. Fruit: receptacle villous, achenes glabrous.

The Silver Weed is a tufted plant, with elongated pinnate leaves composed of from seven to seventeen leaflets, which are sharply toothed, green, and smooth on the top, and very silky and whitish underneath. A characteristic feature of the Silver Weed is the minute pairs of leaflets which grow between the real leaflets, but are merely tiny pointed growths. The yellow flowers, which are typical of the whole genus and have five bracts, five sepals, five petals, and numerous stamens, grow on slender naked stalks that spring from the axils of the leaves. The flowers are very pretty and velvety, and commonly grow in the moist meadows, for there

"The Silver Weed with yellow flowers,

Half hidden by the leaf of gray, 
Blooms on the bank of that clear brook Whose music cheers my lonely way."

The Silver Weed creeps along the ground by means of slender many-jointed runners, and its stems are usually curved and winding. When the fruit ripens it consists of a head formed of several little achenes, or nutlets. The Potentillas are very numerous in the mountain regions.

Potentilla dissecta, or Common Cinquefoil, is a low alpine plant, more or less silky and hairy, and has a yellow flower with a five-lobed calyx and five roundish petals. It resembles a miniature rose. The foliage consists of from five to seven toothed leaflets on each stem, the terminal leaflet being three-lobed at the apex.

There are several varieties of this species: Potentilla dissecta var. glaucophylla, or Smooth Cinquefoil, has smooth green leaves; Potentilla dissecta var. multisecta, or Dissected Cinquefoil, has whitish silky foliage, each leaflet being long and narrow; and Potentilla dissecta var. pinnatisecta, or Leafy Cinquefoil, has more numerous leaflets and a one-flowered stem, which grows only about three inches high, the whole plant being smooth, with the exception of the hairy calyx and tufted apices of the leaves.

Many of the Cinquefoils (cinque, "five"; fcuilles, "leaves"), have five-parted leaves, hence their common name.

Potentilla norvegica, or Rough Cinquefoil, is a coarse weed-like plant, with leaves that are divided into three leaflets, and yellow flowers that grow in rather close leafy clusters.

Potentilla Hippiana, or Woolly Cinquefoil, is a stout plant, with quantities of densely floccose and silky foliage. The leaflets are whitish and woolly on both sides, and deeply 
dentated. The flowers are bright yellow, and grow in graceful terminal clusters.

Potentilla gracilis, or Small Cinquefoil, has very small leaves, heart-shaped in outline and composed of from three to seven leaflets, which are white and woolly beneath and green and silky on the top. The little flowers are yellow.

Potentilla nivea, or Alpine Cinquefoil, grows at great altitudes and is found at 8500 feet. It is a tiny plant, with small trifoliate white and woolly leaves and wee terminal yellow flowers.

In studying the Potentillas it is wise to refer to the Ranunculi, also recorded in this Section, and note the close resemblance yet distinct variations which exist between the two genera. The differences between the foliage of the Potentillas and that of the Ramunculi have already been referred to in the description of the latter plants, but it may be further noted here that the stamens of the Ramunculi are hypogynous, or borne at the base or below the ovary, while those of the Potentillas are perigynous, or borne on the perianth around the ovary.

Potentilla uniflora, or One-flowered Cinquefoil, is densely cæspitose, from a woody base, and has small closely tufted leaves palmately divided, the leaflets being deeply cut and very white-woolly on both sides. The bright yellow flowers are solitary on short stalks and the petals are broad, notched at the apex, and much longer than the narrow, densely hairy sepals.

Potentilla fruticosa, or Shrubby Cinquefoil, renders the dry sunny alpine meadows very gay in July and August with its lovely bright yellow flowers, which resemble large buttercups and grow on low bushy shrubs, amid much silvery foliage, composed of tiny compound leaves covered 


\section{$330 \quad$ Yellow to Orange Flowers}

with a soft silky down. The bark on the slender stems is extremely shreddy.

\section{YELLOW AVENS}

Geum strictum. Rose Family

Stems: ascending, pubescent, branched above. Leaves: basal ones lyrate-pinnate; leaflets five to seven, obovate, cuneate, dentate, with a few smaller ones interspersed, the terminal one largest; stem-leaves sessile, with three to five ovate acute segments. Flowers: several, terminal, of five petals.

This is a common plant, with bright yellow five-petalled flowers and large foliage. Each leaf is pinnately divided and has one big terminal segment and from four to six smaller leaflets, interspersed with some very tiny ones. The most noticeable feature is the fruit, which consists of a ball of seeds, each one terminating in an elongated barbed style.

Geum macrophyllum, or Large-leaved Avens, is very like the preceding species, but it has much larger, coarser foliage. It also has bright yellow flowers and a bur-like head of seeds, each one of which terminates in the same slender, jointed, hooked style which is a distinguishing characteristic of this genus of plants.

Both the Yellow Avens and the Large-leaved Avens have lobed and toothed leaves and small clove-scented flowers. They are rough hairy plants and resemble weeds.

Unattractive as is the coarse foliage of the Geums, yet their primrose-tinted blossoms gleam like jewels of pale gold amidst the dark green leaves, and these redeem the plants from utter ugliness. 


\section{DRUMMOND'S DRYAS}

\section{Dryas Drummondii. Rose Family}

Low, tufted, herbaceous shrubs. Stems: woody at the base. Leaves: oval, crenate-dentate, green and glabrous above, white-canescent beneath. Flowers: yellow, solitary; calyx persistent, its tube concave, hirsute lobed; petals numerous; style elongated and plumose in fruit.

This insignificant little yellow flower, which meekly droops its head as if conscious of its lack of good looks, has the most lovely plumose seed-heads imaginable; and there are few prettier sights in the mountains than that of some low-lying alpine meadow literally covered with these frail feathery tufts, rising up on their long, slender, woody stems several inches above the prostrate foliage, half of which is curled over to show its silvery lining; for all the leaves of Drummond's Dryas are green and shining on the top and white and silky underneath. The flower consists of numerous small yellow petals enclosed in a short, hairy, green calyx; but as soon as these die and fall off, the stalk elongates and the seed-head quickly develops. This plant will grow in the poorest soil, and is most frequently found on arid gravel beds and in the gravelly battures of the alpine streams.

\section{YELLOW MELILOT Melilotus officinalis. Pea Family}

Stems: ascending, one to four feet high, branching. Leaves: trifoliolate, petioled, rather distant; leaflets oblong, serrate, narrowed at the base, rounded at the apex. Flowers: in slender racemes; standard equalling the wings and keel. Not indigenous.

The Yellow Melilot, or Sweet Clover, closely resembles the White Sweet Clover. It has spike-like racemes of tiny clustered flowers, which are fragrant and extremely deli- 
cate both in shape and hue, and are borne on tall branching stems, which frequently attain a height of three or even four feet. The leaves are trifoliolate and smell very sweet when dried. They droop in a peculiar fashion at nighttime, the upper leaflet and one side leaflet closing together, until the vertical surface of each comes in contact with that of the other, while the third leaflet is left alone, exposed to the chills and rains of the hours of darkness. This is an introduced plant.

\section{LOCOWEED}

Oxytropis Lamberti. Pea Family

Silky-pubescent with appressed hairs, aculescent, tufted. Leaves: odd-pinnate; leaflets linear, oblong, acute; peduncles longer than the leaves. Flowers: in large dense heads, or spikes. Fruit: pods incompletely two-celled, coriaceous, sessile, erect, ovoid-cylindric, long-acuminate.

A handsome rich cream-coloured or yellowish species of Oxy'tropis, with soft whitish silky foliage and very fine large flower-spikes. It usually grows on the dry alpine meadows.

Oxytropis monticola, or Mountain Oxytrope, is silverypubescent throughout with very fine hairs. The leaflets are oblong and pointed, sometimes rather blunt at the apex, and the Howers are pale yellow and grow in dense heads on long stalks. The calyx is covered with long white and short black hairs. This species grows in the high alpine meadows.

\section{SCOULER'S ST. JOHN'S-WORT}

Hypericum Scouleri. St. John's-wort Family

Stems: simple or sparingly branched above, often with small branchlets growing from running rootstocks. Leaves: opposite, obtuse, clasp- 


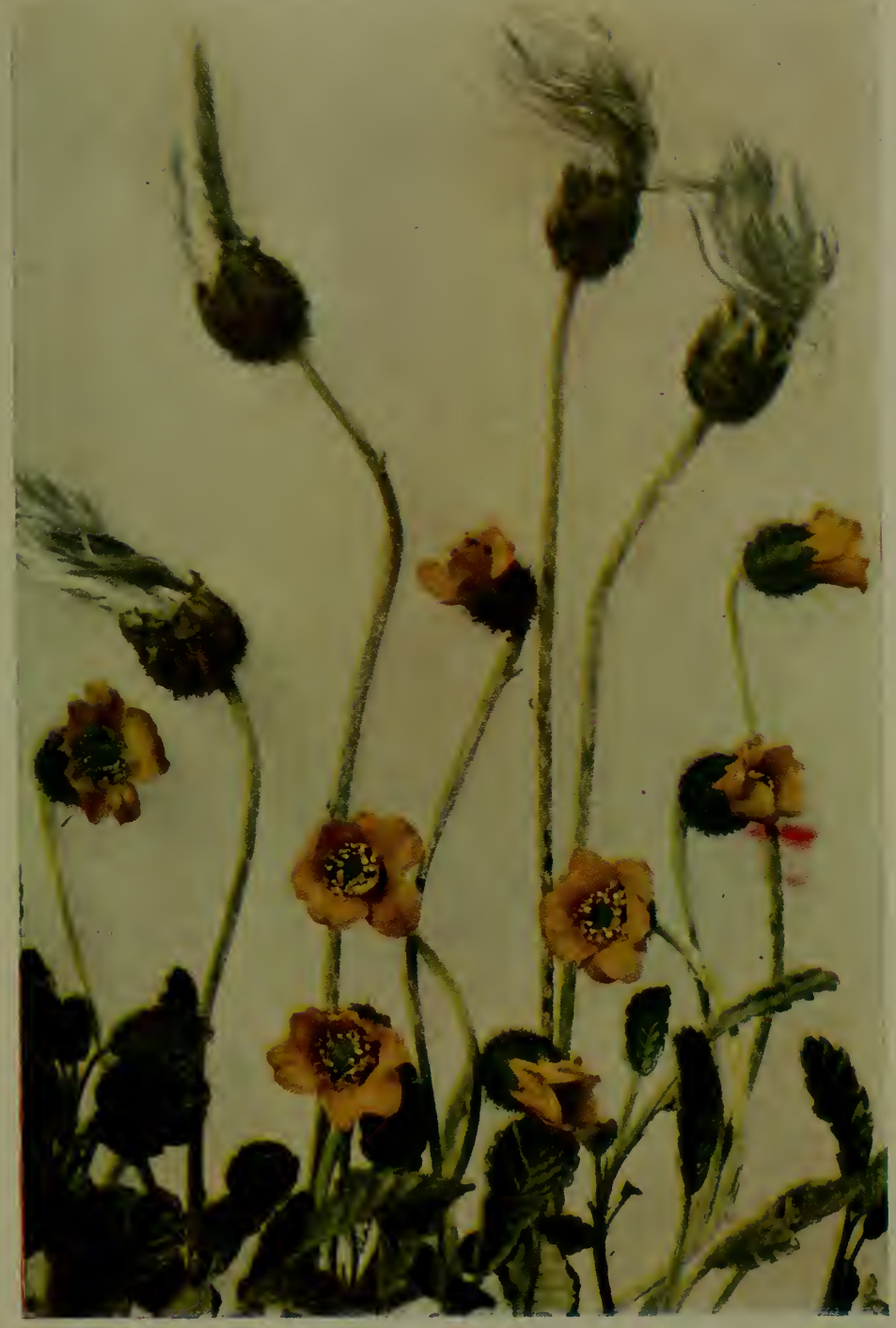

DRUMMOND'S DRYAS

(Dryas Drummondii) 

ing, entire. Flowers: in panicled cymes, stamens numerous, in three fascicles. Fruit: capsule conical to globose, one to five celled.

A handsome plant growing from one to two feet high, having clasping entire leaves which are usually black-dotted along the margins, and bright yellow rosin-scented flowers growing in an open branched cluster. There are many quaint superstitions connected with this plant. It was formerly believed to be a safeguard against the evil spirits who walked abroad on St. John's Eve, and was gathered by the country people with great ceremony, and hung up over their doors to avert thunder and lightning; while its ancient name of Balm-of-the-IVarrior's-WVound denotes that its healing properties were much prized. It was also called Fuga Damonum because it was believed to be a sovereign remedy to cure melancholia, a fact Huxford refers to:

"So then about her brow

They bound Hypericum, whose potent leaves

Have sovereign power o'er all the sullen fits

And cheerless fancies that besiege the mind;

Banishing ever, to their native night,

Dark thoughts, and causing to spring up within

The heart distress'd, a glow of gladdening hope,

And rainbow visions of kind destiny."

\section{YELLOW VIOLET \\ Viola glabella. Violet Family}

Stems: glabrous, slender, from a short fleshy horizontal rhizome. Leaves: radical ones on long petioles, the upper short-petioled, reniformcordate, crenately toothed. Flowers: bright yellow.

This is a small plant which blooms close to he ground, and is found chiefly at high altitudes.

"When beechen buds begin to swell, And woods the bluebird's warble know, The yellow violet's modest bell

Peeps from the last year's leaves below." 
Its bright golden flowers are finely pencilled in the centre with black lines, and grow on short slender stalks anid a mass of small roundish leaves.

Viola orbiculata, or Round-leaved Yellow Violet, has a thick rootstock with a few fibrous rootlets, mostly rounded, heart-shaped, crenulate basal leaves, slightly hairy on the upper surface; and yellow petals, the lower one being purple-veined. The spurs are short and saccate.

Viola scmperiircns, or Trailing Yellow Violet, has weak, decumbent stems, and spreads by means of long, slender rootstocks. The leaves are mostly basal, and are rounded, cordate at the base and finely round-toothed at the edges. The yellow flowers grow on long stalks, and their petals are sparingly veined with brown near the base, the spur being short and like a sac. This species grows chiefly in burnt woods.

\section{SILVERBERRY}

\section{Elcagnus argentea. Oleaster Family}

Stoloniferous, silvery-scaly, much branched. Leaves: alternate, oblong, ovate, densely silvery-scurfy on both sides, acute or obtuse. Flowers: one to three in the axils, pedicelled, fragrant; perianth silvery without, yellow within, tubular below, the upper part campanulate, fourlobed, the lobes ovate. Fruit: oval, silvery.

A most extraordinary and attractive shrub, growing from two to twelve feet high and entirely covered with a lovely silver coating. The leaves are small and very crinkled and wavy, and the flowers quite tiny, their bellshaped four-lobed corollas being silvery on the outside and pale yellow within. The stems, branches, leaves, and fruit are completely silvered over and thus may be readily distinguished, 
PLATE LXI

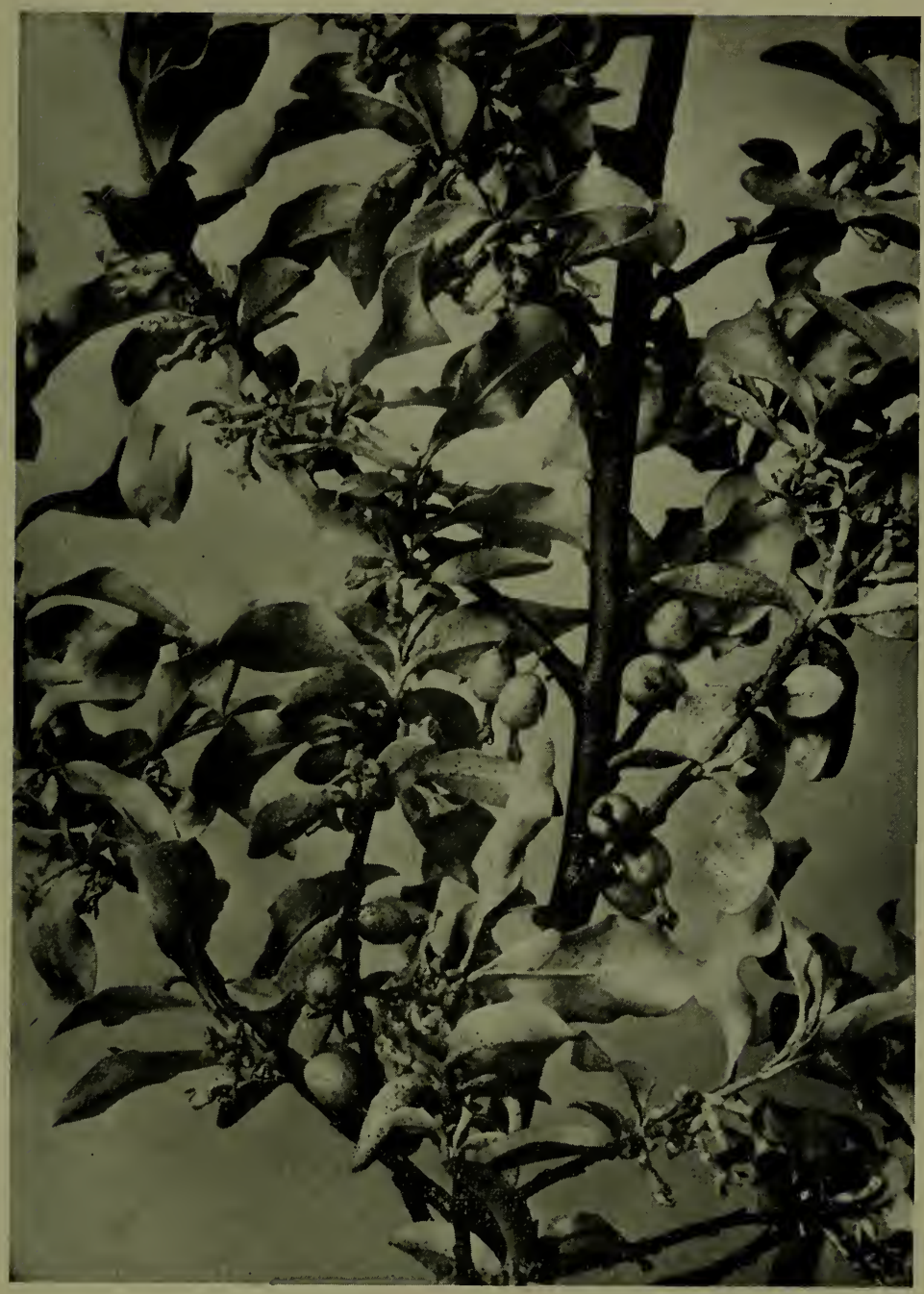

SilverberRy

(Elcagnus argentea) 


\section{CANADA BUFFALOBERRY}

\section{Shepherdia canadensis. Oleaster Family}

Leaves: ovate or oval, obtuse at the apex, rounded or narrowed at the base, green and sparingly stellate-scurfy above, densely silvery stellate-scurfy beneath, some of the scurf brown. Flowers: in short spikes at the nodes of the twigs, yellowish, buds globose; perianth four-lobed. Fruit: oval, drupe-like, red or yellow.

This shrub somewhat resembles Elcagnus argentea, but is not nearly so silvery in appearance, the stems being covered with a brown scurf and the leaves being green and slightly brown-scurfy on the top and silver-coated only underneath. The yellow flowers are small and grow in short spikes at the joints of the twigs; the fruit consists of a bright scarlet or yellow berry, the flesh of which is edible, though very insipid, and contains a tiny smooth nut.

The Canada Buffaloberry grows from four to eight feet high, usually near water, and when in fruit is extremely ornamental.

\section{YELLOW WILLOW-HERB}

Epilobium luteum. Evening Primrose Family

Stems: slender, nearly simple. Leaves: ovate, acute, sinuate-toothed, sessile. Flowers: from the axils of the upper somewhat crowded leaves; corolla funnel-form, rarely expanding, the lobes deeply notched; calyx short and deeply cleft.

The pale lemon-coloured flowers of the Yellow Willowherb grow in quantities near running water, or in the deep moist valleys where the rushes whisper in their husky throats and the moss weaves lace-like patterns to cover the ground. The plant stands from six inches to two feet high, and has large, conspicuously veined leaves, with wavy margins, which are very sharply toothed. The flowers are extremely pretty and delicate in hue; their foun petals, 
folded in funnel-form, rarely expand, and are held up in green calyx-cups, which in their turn are cleft into four narrow slender divisions.

\section{COMMON EVENING PRIMROSE}

\section{Enothera biennis. Evening Primrose Family}

Stems: erect, stout, wand-like. Leaves: lanceolate, acute, narrowed and sessile at the base, repand-denticulate. Flowers: spicate, terminal, leafy-bracted; calyx-tube slender, the lobes linear, reflexed.

The Evening Primrose, whose bright yellow blossoms open in the twilight, somewhat resembles the Yellow Willow-herb, whose paler flowers bloom at the bidding of the sunshine. Seen in the daytime, the Evening Primrose appears faded and uninteresting; but viewed at night, its fragrant flowers are exceedingly attractive. The plant grows to an average height of three feet, and has alternate lance-shaped leaves and erect buds. No sooner has the sun set than the buds begin to expand, the closely closed calyx suddenly bursting open with a loud pop, and then one by one the petals slowly unfold, until the whole sulphur-coloured flower is wide-blown and sends forth its sweet fragrance to scent the evening air.

\section{"A tuft of evening primroses}

O'er which the mind might hover till it dozes,

But that it's ever startled by the leap

Of buds into ripe flowers."

A single summer night suffices to consume the vitality and beauty of this flower, which at evening is fresh and fair and newly blown, and by noon looks faded and most dejected. It is strange how very fragrant and lovely are many of these "flowers that blow when the heat of the day is o'er," such, for instance, as the Night-blooming Jessamine, 
the Night-blooming Cereus, and the Night-blooming Cactus. The yellow petals of the Evening Primrose shine so luminously in the dusk that they easily attract the crepuscular moths, which fertilize the plants by carrying the abundant sticky pollen from one flower to another. The number four is conspicuous in this flower, which has four petals, a four-parted calyx, eight stamens, a four-celled ovary, and a four-cleft stigma. When the corolla fades, after its single night of revelry, it soon shrivels and drops off, and then the oblong capsule containing the seeds quickly matures

\section{HEART-LEAVED ALEXANDERS}

Zizia cordata. Parsley Family

Stems: erect, branched. Leaves: upper stem-leaves compound, shortpetioled, ternate, the segments ovate, crenate-dentate; basal leaves longpetioled, sometimes undivided. Flowers: in umbels, eight-to-twelve rayed. Fruit: globose-oroid.

The bright shining green leaves of this Parsnip and its brilliant golden umbels of minute flowers combine to render it one of the many handsome plants that deck the damp alpine meadows. It has stout hollow stalks and very glossy foliage, the leaves being ternate, or arranged in threes, with broad, wavy-margined, sharply toothed leaflets. It has a most disagreeable odour.

\section{NARROW-LEAVED PARSLEY}

Lomatium tritcrnatum. Parsley Family

Stems: from a deep-seated elongated fusiform root. Leaves: biternate or triternate, the leaflets narrow, linear. Flowers: in an unequal umbel of five to eiglteen rays with slender bracts.

The yellow flowers of this tall Parsley have no involucre. The stems are purplish at the base and the leaves are deeply cut into narrow leaflets. The fruit is narrowly oblong with 
narrow wings, and the oil tubes are very large and solitary in the intervals between the dorsal and intermediate ribs.

Lomatium Martindalei var. angustatum, or Martindale's Parsley, is caulescent and branching with elongated peduncles. The leaves are pinnate or bipinnate with toothed segments. The flowers are yellow, and the fruit has broad wings and prominent dorsal and intermediate ribs; the oil tubes are solitary in the intervals, and the seed-face is concave with a central longitudinal ridge.

\section{NARROW-LEAVED PUCCOON}

\section{Lithospermum angustifolium. Borage Family}

Stems: branched, erect or ascending. Leaves: linear, sessile, acute. Flowers: of two kinds, in terminal leafy racemes; corolla of the earlier ones salver-form, bright yellow, five-lobed, the lobes erose-denticulate, the throat crested; later flowers much smaller and pale yellow, cleistogamous, abundantly fertile, their pedicels recurved in fruit. Fruit: nutlets white, smooth, shining, ovoid, more or less pitted, keeled on the inner side.

The French call this Puccoon Plante aux Perles, because of the hard stony seeds that mature in the calyx, and which, though at first soft and green, gradually become hard, white, and shining. It is on account of these nutlets that the plant is named from the Greek lithos, " a stone," and sperm, "a seed." The flowers are a pretty lemon colour, the earlier ones being of a much deeper shade and larger in size than those which appear later in the summer. They grow in close leafy clusters, and have a long, salver-form, five-cleft corolla. The stems and leaves are quite downy. This Puccoon grows in small tufts or mats, from six to ten inches high, and is usually found on the dry open lands, where its

"Leaves and branches, crossed and linked, Cling like children and embrace." 
Lithospermum ruderale, or Hairy Puccoon, has numerous soft-hairy, very leafy stems growing from a crown of thick roots. The leaves are narrow and tapering, and the yellow flowers are densely crowded in a leafy thyrsus. The narrow sepals are hairy, and the campanulate-funnelform corolla is twice as long as the calyx, and silky outside. The white bony nutlets are ovate, pointed and polished. Both these Puccoons have a sweet smell.

\section{YELLOW BEARD-TONGUE}

\section{Penstemon confertus. Figwort Family}

Stems: slender. Leaves: lower ones lanceolate, attenuate below to narrow petioles, mostly entire, the cauline sessile by a broad base. Flowers: thyrsus spiciform, interrupted, dense, many-flowered clusters; corolla very narrow, lower lip conspicuously bearded within.

The Yellow Beard-tongue grows high up on the mountains. The flowers, which vary in hue from yellow to cream colour, are set in several dense clusters round about the stem, encircling it at intervals.

\section{YELLOW MONKEY-FLOWER}

\section{Mimulus Langsdorfii. Figwort Family}

Stems: erect. Leaves: ovate, sessile, denticulate. Flowers: terminal; calyx ventricose-campanulate; corolla-tube cylindric, its limb bilabiate, the upper lip erect, two-lobed, the lower lip spreading, three-lobed.

A small plant bearing abnormally large quaint flowers, bright yellow in colour and usually spotted with brownishred inside the corolla. The lower three-cleft lip is heavily bearded within by soft fine hairs, and so tiny are the little roundish leaves, and so slim the short stems, that the big bright blossoms appear rather top-heavy for so small a plant. Not actually growing in the water, but rather on 
those low marshy islands so frequently set in the middle of the alpine streams, you will find myriads of these Yellow Monkey-flowers nestling amid the mosses and reeds which spring up so luxuriantly between the stones by the river's brink.

Mimulus moschatus, or Musk Flower, is hairy and very sweet-smelling. The stems are creeping or ascending, and the slender branches are six to twelve inches high. The ovate pointed toothed short-stalked leaves are rounded at the base, and the bright yellow flowers, growing on a short stalk, have a funnel-form corolla with a spreading limb.

Mimulus alpinus, or Alpine Monkey Flower, is a densely matted plant, perennial by stolons, and found growing at high altitudes. The leaves are oval, and the solitary yellow flowers terminate the short stems.

\section{PELICAN FLOWER}

Orthocarpus luteus. Figwort Family

Stems: strict, erect, branched above, densely leafy. Leaves: ascending, linear, entire or sometimes three-cleft, sessile, long-acuminate; bracts of the dense spike lanceolate. Flowers: in dense spikes, yellow; calyx tubular, with acute teeth; corolla-tube slender, the limb two-lipped, the upper lip ovate, obtuse, the lower lip saccate, three-toothed.

An uninteresting member of the numerous Figwort Family. It has dense, slender, erect spikes, covered with tiny leaves and bracts, and numerous bright yellow flowers. These flowers have a single upper lip and a three-toothed lower lip; they are very fragrant, and the large pouch and queer slender beak suggest the name of Pelican Flower. This plant is usually found in dry soil. 


\section{YELLOW RATTLE}

Rhinanthus Crista-galli. Figwort Family

Stems: slender. Leaves: lanceolate, sessile, coarsely serrate-dentate, acute, bracts ovate, incised-dentate, the teeth acuminate. Flowers: in terminal, one-sided, leafy-bracted spikes, and solitary in the upper axils; calyx much inflated, conspicuously veiny in fruit; corolla very irregular, two-lipped; the galea compressed, arched, minutely two-toothed below the entire apex, the lower lip three-lobed, spreading.

The name Yellow Rattle has been given to this plant on account of the way in which the ripened seeds, which lie loose in the capsules, rattle whenever the wind shakes them to and fro. It is a firm erect plant, usually growing from six to ten inches high, and chiefly conspicuous by reason of its inflated green flower-cups and bright yellow blossoms, the lips of which frequently are spotted with purple.

\section{GREATER BLADDERWORT}

Utricularia vulgaris var. americana. Bladderwort Family

Stems: immersed, scape stout, naked, three to four inches high, with a few scales. Leaves: two to three pinnately many-parted, capillary, bearing many bladders. Flowers: three to twenty in a raceme on short pedicels, the sides of the lips reflexed, spur conical, slender, rather acute. Fruit: capsule many seeded.

The Greater Bladderwort is a very curious plant which grows in shallow pools and ponds, and has yellow flowers similar in structure to those of the Butterwort. The leaves, usually much crowded on the floating branches, are divided into thread-like segments bearing the numerous, velvetylooking, little air bladders. In the autumn, buds terminating the stems fall off, and are buried in the mud at the bottom of pools until springtime, when they root, and the new bladders, at first filled with water, soon fill with air, and the plant, leaving the mud, rises to the surface of the 
pool and flowers, the bladders feeding it by means of their trapping. The pale green bladders are, however, its most interesting feature, for having no roots the plant floats submerged by means of these tiny inflated balloons, whose bristle-like appendages give them the appearance of crustaceans. These bladders have an opening closed by a valve and furnished with a few projecting bristles that guide insects to the aperture, which they enter by pressing against the lid. Inside the bladder is covered with glandular processes that seem to absorb the fluid products of decay, but do not, like the Butterwort and Sundew, digest the trapped victim and absorb the animal matter. The yellow flowers grow in racemes of three to twenty at the top of the stalks on pedicels which are recurved in fruit. They have a twolipped corolla with an erect, entire upper lip, and a broad three-lobed lower lip that has a large palate, and a conic spur nearly as long as the lip to which it is appressed.

Utricularia intermedia, or Yellow Bladderwort, has also a naked scape bearing one to five yellow flowers, the upper lip of whose corolla is much longer than the palate, the acute spur being appressed to, and as long as the very broad lower lip. The slender pedicels are erect in fruit. The branches are floating, and the leaves more or less scattered, with linear, flat segments and bristle-toothed margins. The bladders are, with rare exceptions, borne on leafless branches.

\section{INVOLUCRED FLY HONEYSUCKLE}

\section{Lonicera involucrata. Honeysuckle Family}

Leaves: ovate or oval, acute or acuminate at the apex, narrowed at the base; peduncles axillary; bracts foliaceous, ovate; bractlets also large, at length surrounding the fruit. Flowers: in pairs, yellow; corolla pubescent, funnel-form, the limb five-lobed, the lobes short, little 


\section{$344 \quad$ Yellow to Orange Flowers}

spreading; stamens and style slightly exserted. Fruit: berries nearly black.

This is one of the small-flowered Honeysuckles which grow in the form of a bushy shrub. It bears yellow funnelform twin blossoms, terminating the long slender peduncles which spring from the axils of the leaves. These blossoms are conspicuously involucred (hence the common name) by large broad leaf-like bracts, which are green in the flowering season and turn a warm reddish colour in autumn, when surrounding the fruit. The five stamens protrude slightly beyond the corolla, but the style is much exserted, and is tipped by a large anther.

The Involucred Fly Honeysuckle is a straggling shrub, growing from two to six feet high; the leaves are longshaped and have hairy margins, and when in fruit the reddish-black berries are joined together in pairs. It is not a plant that is likely to attract the traveller's interest, for it is noticeable only by reason of its rich luxuriant foliage, since the flowers are small and the berries quite dark in hue.

Loniccra utahcnsis, or Bush Fly Honeysuckle, grows from three to five feet high, and is branching and very bushy. The leaves are oblong and bright green and have wavy smooth margins. The pale yellow flowers, whose corollas are cleft into two lips, grow in pairs on long slender peduncles from the axils of the leaves, and are subtended by small bracts, in which latter respect they differ materially from the Involucred Fly Honeysuckle, which has very large broad bracts. The fruit consists of egg-shaped berries, which are more or less joined together and are of a lovely translucent scarlet colour,-

"Like a double cherry, seeming parted." 


\section{PLATE LXII}

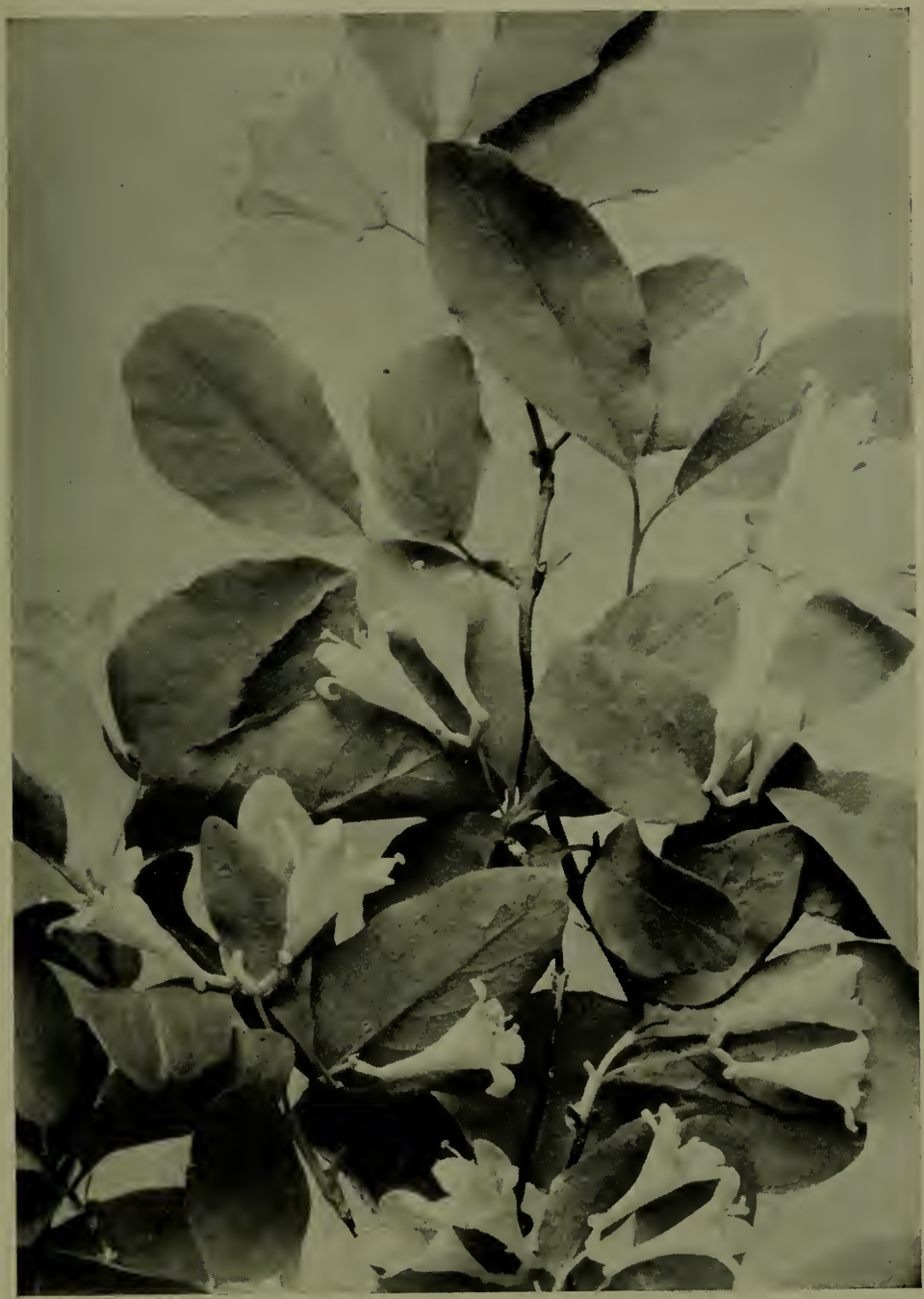

Bush Fly Honeysuckle

(Lonicera utahensis) 


\section{GOLDEN ASTER}

Chrysopsis villosa. Composite Family

Stems: villous. Leaves: alternate, oblong, obtuse, the upper ones sessile, the lower ones narrowed into a petiole, pale, canescent with appressed hairs. Flowers: heads few, terminating the short branches; rays oblong-linear; involucre hemispheric. Fruit: achenes obovate.

The yellow Aster is a very hairy plant, it affects dry or sandy soil, and grows from six to eighteen inches high. The stems are simple, and near the summit short branches spread out, terminating in the solitary heads, which are composed of both tubular and radiate flowers. These bright golden flowers are enclosed in an involucre, which is formed of several series of tiny green bracts. The name Chrysopsis, from chry'sos, "gold," and opsis, " aspect," is peculiarly applicable to these gay yellow blossoms, which glorify the dry waste places with their shining splendour.

Chrysopsis hispida, or Hairy Golden Aster, is a lower plant than the preceding species and has numerous stems growing from a woody rootstock. It is hispid or roughhairy throughout. The leaves are spatulate entire and spreading, obtuse at the apex and narrowed at the base into long petioles. The flower heads are numerous and bright yellow, and the involucre has lanceolate hirsute bracts.

\section{CANADA GOLDEN-ROD}

Solidago canadensis. Composite Family

Stems: stout, little branched, puberulent. Leaves: alternate, lanceolate, triple-nerved, acute at each end, the lower ones sharply serrate and petioled, the upper ones smaller, entire, sessile. Flowers: heads numerous, of both tubular and radiate flowers, on the spreading or recurving branches of the large and dense panicles; involucre campanulate, the bracts linear, imbricated in several series; rays in one series, pistillate; disk-flowẹrs ñearly all perfect; corolla tubular, five-cleft. 
The Golden-rods, many species of which grow abundantly in the mountain districts, are, together with the Asters, the handsomest of the late autumn flowers. Retaining the rich glow of the summer sun in their ripe yellow blossoms, they brighten the slopes and border the trails with a reflected glory. For the Golden-rod is at home in all kinds of places : by the dusty wayside and in the deep green forests; close to the borders of the ice-born streams, and out in the open meadows, where the rays of light at noontide shine strongest. In each of these localities the tall wands, bearing their wealth of golden florets, wave gently to and fro, and never can we mistake the feathery plumes of the larger species, or the straight woody stems of the smaller ones, which are so thickly crowned by the tiny radiant flowers of this queen of Nature's garden.

It is a more difficult matter, however, to differentiate between the many species of Golden-rod that grow at high altitudes. The Canada Golden-rod is perhaps the easiest one to recognize, since it is the largest as well as the handsomest of its tribe, and has big branching panicles of closeclustered blossoms, very long, narrow, pointed leaves of a dull grayish-green hue, and stout woody stems, which have a cottony appearance and attain an average height of three feet.

So numerous are the Golden-rods on this continent that it is possible to note only a few of the more conspicuous species which the traveller is likely to find and gather in the course of his wanderings amid the great hills, where

"Along the roadside, like the flowers of gold That tawny Incas for their gardens wrought, Heavy with sunshine droops the Golden-rod." 
Solidago decumbens, or Field Golden-rod, has tall, stiff, wand-like stems, which terminate in dense compact panicles of flowers, and sparse, long, narrow leaves, with even margins. It is very beautiful to walk across the alpine fields, where

\section{"The Golden-rod lights slowly \\ Its torch for the Autumn blaze,"}

and where the other fall flowers unite to celebrate the passing of summer in a riotous splendour of scarlet, purple, and gold.

Solidago multiradiata, or Northern Golden-rod, is a coarser species with small loose clusters of rather large deep yellow flowers, which terminate the leafy downy stems.

"How deepening bright, like mountain flame, doth burn The Golden-rod upon a thousand hills.

This is the Autumn's flower, and to my soul

A token fresh of beauty and of life, And life's supreme delight."

Solidago missouriensis, or Mountain Golden-rod, has a perfectly smooth slender stem and short, broad, branching panicles of yellow flowers. The leaves are thick and lanceshaped, with entire rough margins. It grows in dry soil and rears its clusters of golden bloom where the sunlight and shade interlace at the edge of the forests.

Solidago nemoralis, or Gray Golden-rod, is so called on account of its gray-green cottony stems and leaves. The latter are lance-shaped and sharply toothed.

Thus we see that the Golden-rods grow everywhere, from the high hill-crests to the deep sweet valleys; that some species attain to a height of six feet under certain very favourable conditions, while others grow in dwarf 


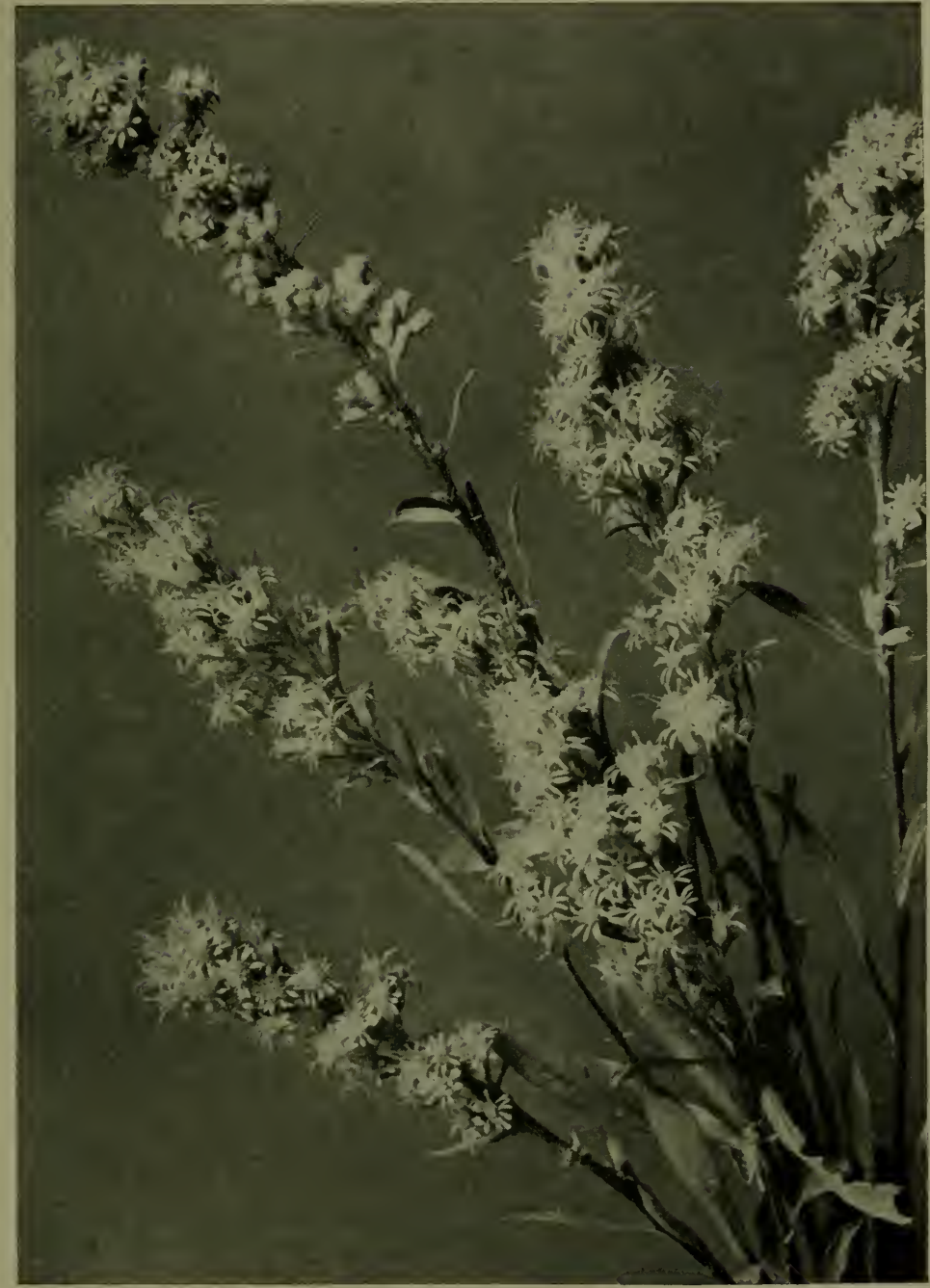

Field Golden-Rod

(Solidago decumbens) 
alpine forms, well-nigh prostrate upon the ground; some are slender-stemmed, some have stout woody support; some bear big branching panicles of abundant bloom, while others again have but few blossoms closely clustered about their erect stalks. Yet in spite of all these differences between the various species, the Golden-rods are quite unmistakable as a genus.

Solidago elongata, or Slender Golden-rod, has smooth slender stems and lanceolate leaves pointed at both ends and sparingly toothed. The flowers grow in an elongated narrowly pyramidal cluster, and the bracts of the involucre are linear, the yellow rays being small and slender. The achenes are pubescent.

\section{YELLOW FLEABANE}

Erigeron aurcus. Composite Family

Stems: from a tufted caudex, cinereous-pubescent, the involucre lanuginose-tomentose. Leaves: radical ones obovate or spatulate, contracted into a slender petiole; cauline ones few, sparse, small. Flowers: in heads of radiate and disk-flowers; rays eight to twelve, ligulate, pistillate, oblong; disk corollas perfect, dilated towards the summit, deeply fivetoothed. Fruit: achenes oblong-turbinate, densely silky villous.

This is a dwarf herbaceous plant, with a tuft of tiny green leaves at the base and one or two minute ones clinging to its stems. It grows only from three to six inches high, and is found on lofty summits at 8000 and 9000 feet. The flowers resemble bright yellow daisies, and are rather ragged looking. At times, as the traveller stands upon some mountain top, where the earth seems very close to the sky of perfect blue, the gamboge blossoms of the Yellow Fleabane, covering the ground with a torrent of bloom, seem to surge across the alpine plateaux in a succession of golden waves. 


\section{BLACK-EYED SUSAN}

\section{Rudbeckia hirta. Composite Family}

Stems: simple or sparingly branched, often tufted. Leaves: thick, serrate with low teeth or entire, lanceolate, the lower and basal ones petioled, the upper ones narrow, sessile, acute. Flowers: heads few or solitary. Fruit: achenes four-angled, obtuse or truncate at the apex, pappus none.

This plant has many names, and among them that of Golden Jerusalem possibly fits it best, since it has truly shining orange-yellow flowers. It is hairy throughout, with thick lance-shaped, almost entire leaves, striking flower heads of ten to twenty bright rays, and a dark purple-brown globose disk that is extremely prominent.

\section{GIANT SUNFLOWER}

Helianthus giganteus. Composite Family

Perennial by fleshy roots and creeping rootstocks. Stems: erect, hispid, branched near the summit. Leaves: lanceolate, very rough above, pubescent beneath, serrate, acuminate at the apex, narrowed at the base. Flowers: rays spreading, entire; disk-flowers perfect, fertile; corolla tubular, the tube short, the limb five-lobed; involucre lic:-ispheric, hirsute.

What the cultivated Sunflower is to the other divellers in old-fashioned gardens the wild Giant Sunflower is to the other dwellers in the woodlands. It is the gorgeous ornament and lord of the locality, one of the most conspicuous of the many flowers that might fairly be designated by the term helios, "the sun," and anthos, " a flower "; for the yellow Asters, Gaillardias, Arnicas, and Ragworts are really all equally amenable to this title.

The Giant Sunflower has large blossoms, composed of numerous bright yellow rays and a disk of perfect fertile 
florets. The leaves are lance-shaped and very rough to the touch.

The Irish poet, Moore, referring to this flower as an emblem of constancy, has sung that

"The Sunflower turns on her god when he sets

The same look which she turn'd when he rose."

But fact, unfortunately, refuses to corroborate his romantic fancy for alas! the Helianthus does not turn its big golden flower-face from east to west to follow the course of the sun god, but, on the contrary, remains in the same position all day long.

In olden days, in Peru and Mexico, this flower occupied an important place both in the mythology and in the sculpture of the country, and also was employed as a mystic and sacred emblem by the inhabitants. The maidens who waited upon the sun god in the temple wore on their breasts representations of it executed in beaten gold, and it also was extensively cultivated in the gardens of the priests.

The ancient Greeks believed that the Helianthus was the incarnation of the nymph Clytie, who by reason of her great love for Apollo sat for nine days upon the ground intently gazing at the orb of day, until at length she became rooted to the earth and her face was transformed into the shining disk of the Sunflower.

All these legends tend, perhaps, to increase our interest in this handsome plant, whose brilliant-hued blossoms burn with a golden light in the mountain thickets and whose leaves make a waving of slight shadows across the land. 


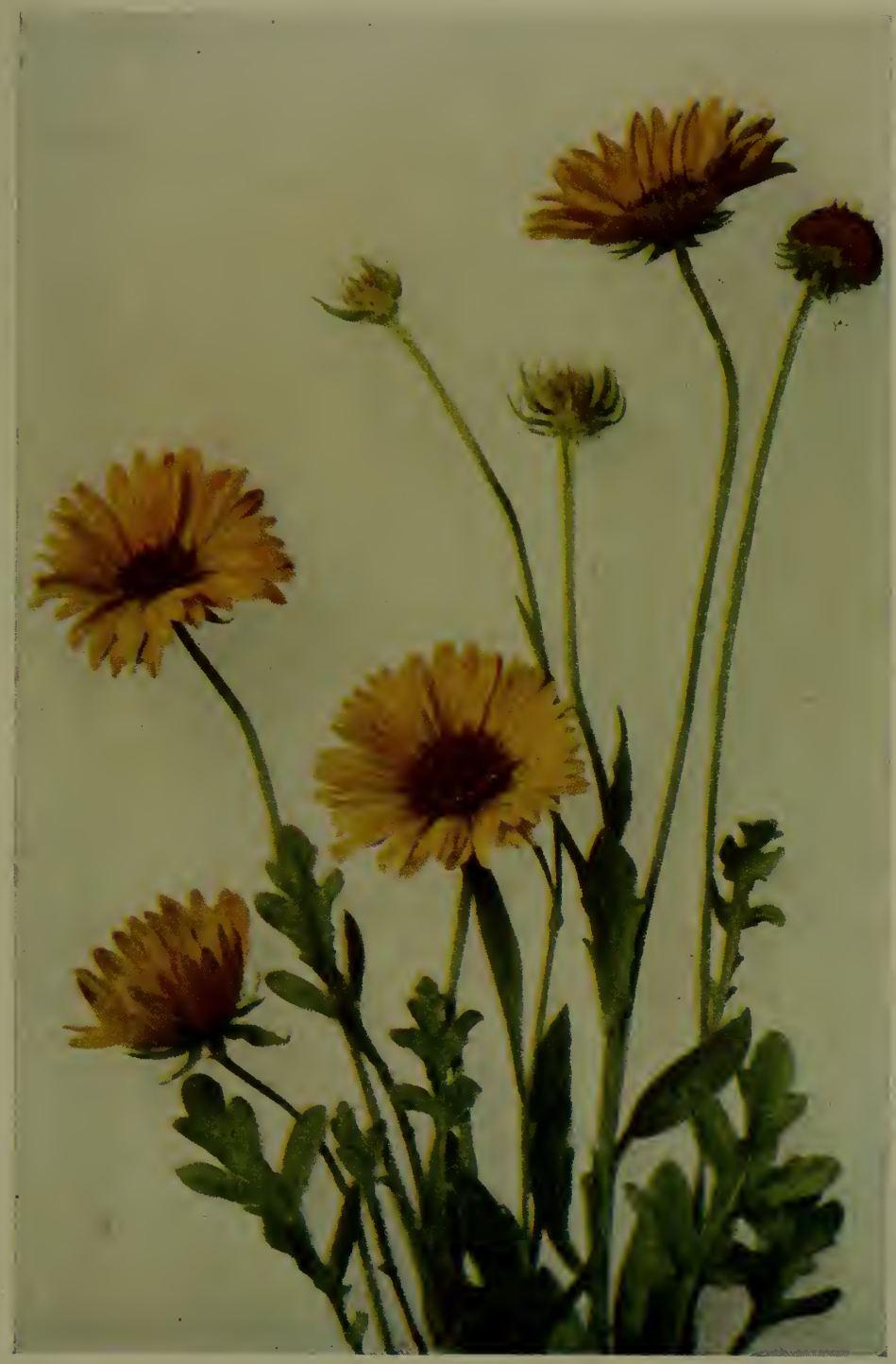

Brown-eyed SÚSAN

(Gaillardia aristata) 



\section{BROWN-EYED SUSAN}

Gaillardia aristata. Composite Family

Stems: simple, or little branched, hirsute with jointed hairs. Leaves: firm, densely pubescent, the lower and basal ones petioled, oblong, laciniate, pinnatifid or entire; upper leaves sessile, lanceolate, entire or dentate. Flowers: large-peduncled, heads of tubular and radiate flowers; rays cuneate, three-toothed; bracts of the involucre hirsute.

A gorgeous radiant blossom, with numerous bright golden rays, which are three-lobed at the apex, and having also a big, fringed, globose, reddish-brown centre, composed of many minute disk-flowers. The leaves are coarse, the larger ones being toothed half-way in the middle.

There are meadows in the mountains rendered more beautiful than any others by reason of these great showy Gaillardias.

Gaillardia Land! It lies far from the busy marts of men. Blue heavens above, and golden flowers about your feet, and all the world full of a very abandon of colour. Here

"A thousand odours rise, Breathed up from blossoms of a thousand dyes."

Ways of peace lead over the fields of rest, and whosoever wanders therein finds food for dreams, and gladness all the way.

"Blue of a burning, boundless sky, Gold of a boundless, splendid sod;

Prodigal noontide, far and nigh,

Blue and gold on the plains of God."

\section{HEART-LEAVED ARNICA}

Arnica cordifolia. Composite Family

Stems: simple, or sparingly branched. Leaves: basal and lower ones ovate, obtuse and deeply corlate at the base, dentate; stem-leaves in pairs, ovate, sessile, small. Flowers: large long-peduncled heads of 


\section{$354 \quad$ Yellow to Orange Flowers}

both tubular and radiate flowers; receptacle flat; rays slightly toothed at the apex.

This is the most common species of Arnica in the mountains, and is a handsome plant, standing from one to two feet high. It has pale green hairy leaves, which are markedly heart-shaped at the base, and many attractive blossoms composed of light golden rays, their deep yellow centres consisting of numerous disk-flowers. These blossoms, which are enclosed in a hairy involucre, formed by a series of narrow green bracts, grow singly or in pairs at the ends of the long slender stalks. The pappus is white.

Arnica latifolia, or Broad-leaved Arnica, has rather slender stems and radical cordate petioled leaves, the upper ones being in two or three pairs, oval, usually sharply toothed, and closely sessile by a broad or contracted base. The flower heads grow on long slender hairy stalks in the axils of the upper leaves, the yellow rays have two notches at the apex, and the bracts of the involucre are oblong with a wicle base and pointed apex. The pappus is white.

Arnica alpina, or Alpine Arnica, is a graceful delicately formed plant, with long, narrow, toothed leaves, and a single flower with ten to fifteen rays, twice notched at the apex, terminating each stem. It also frequently has two additional flowers springing from the axils of the upper leaves. Several pairs of sessile leaves grow on the stems, and altogether the plant presents a more slender, refined appearance than do either of the two preceding species.

Arnica Chamissonis, or Chamisso's Arnica, is an extremely hairy species usually found near water. The leaves are very long, narrow and slightly toothed, the lower ones tapering into a marginal stalk and the upper ones being broad at the base and somewhat clasping. The flowers are 
PLATE LXIV

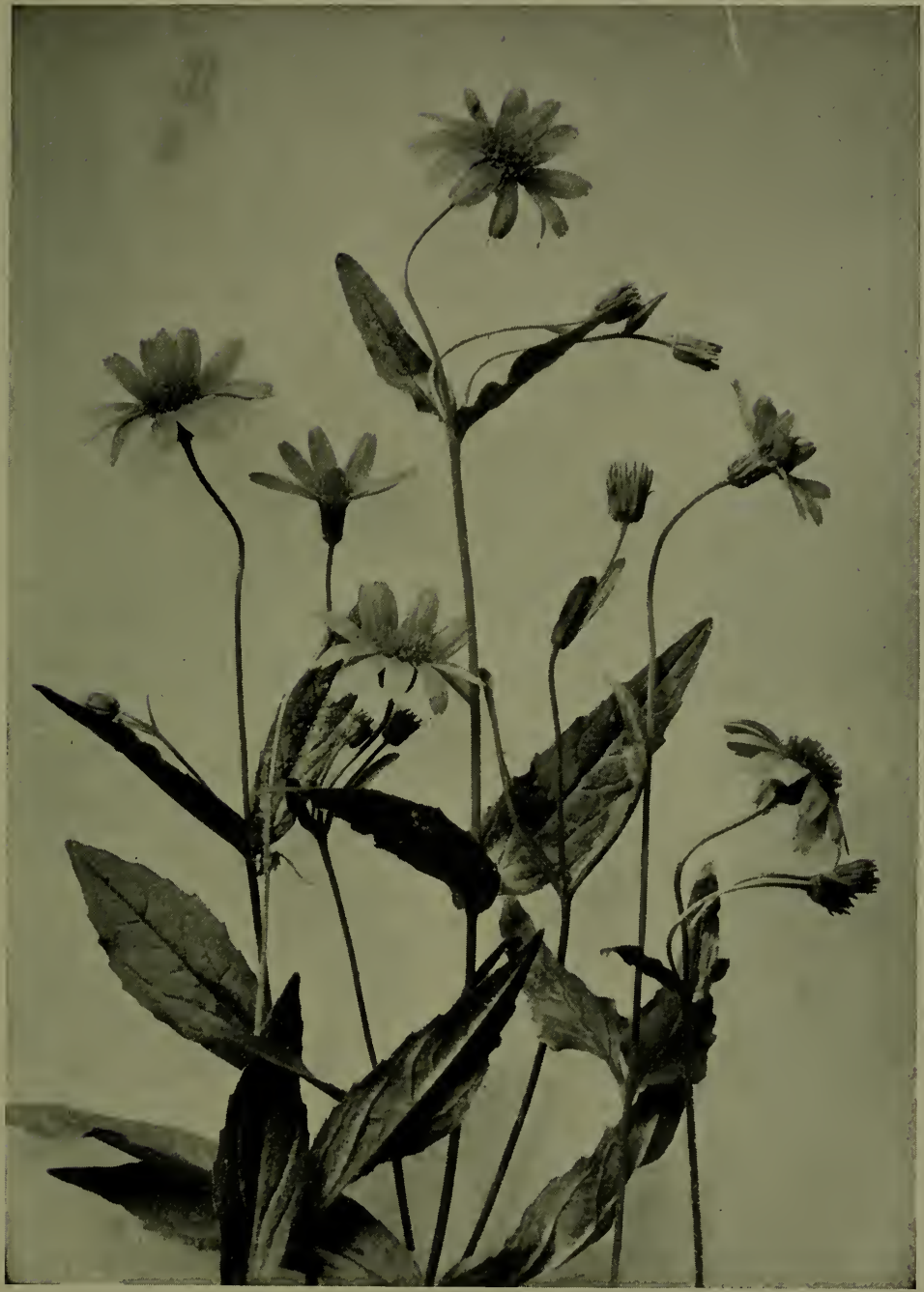

Alpine Arnica

(Arnica alpina) 
smaller than those of the Heart-leaved Arnica, and the pale yellow rays have a single notch at the apex. The pappus is tawny.

Arnica Parryi, or Parry's Arnica, bears a curious flower with no rays at all, but only a receptacle of disk-flowers enclosed in a green involucre. These flower-heads usually grow in threes at the summit of the three short-branched stems. They appear to have simply lost their rays in the early stage of decomposition, but such is not the case; they never had any.

Arnica louiscana, or Schaeffer's Arnica, is a slender hairy plant with nodding flower heads of eight to ten noticeably pale lemon-yellow rays, and usually three pairs of leaves, the lower ones at the base of the stem being elliptical, entire or denticulate. The bracts of the campanulate brownishpurple involucre are lanceolate, acute and densely glandularhairy at the base. The pappus is tawny.

Arnica fulgens, or Notched Arnica, has oblong lanceolate pointed leaves, the lower ones being toothed and stalked, and the upper ones sessile and entire. The flower heads grow on long slender hairy stalks, and the involucre is campanulate, its bracts being pointed and covered with long white hairs. The bright yellow rays are twice notched at the apex and the pappus is white.

Arnica gracilis, or Slender Arnica, is a smooth slender branched plant with slightly hairy leaves, the basal ones being broadly ovate, stalked, toothed and three-ribbed, as are also the two pair of stem-leaves, but the top pair are sessile. The flower heads have long narrow bright yellow rays with a single notch at the apex, and the twelve to fifteen involucral bracts are lanceolate acuminate and hairy, as are also the seeds. The pappus is white. 


\section{GOLDEN RAGWORT}

Senecio Balsamita. Composite Family

Perennial, often tufted. Stems: slender, woolly at the base and in the axils of the lower leaves. Leaves: basal ones slender-petioled, oblong, very obtuse, crenate; stem-leaves pinnatifid, sessile, small. Flowers: in corymbose many-flowered heads of both tubular and ray-flowers.

This is a very common plant in the mountains. It has bright yellow flowers, which when in seed resemble small thistles. The rich loose clusters of the Golden Ragwort grow to an average height of eighteen inches. The basal leaves have long stalks and are rounded or oblong, with scalloped edges, while the stem-leaves are long, narrow, and slender, and very deeply cut. The name Senecio is from scnex, " an old man," and refers to the hoary-headed appearance of the plant when in seed, which is supposed to resemble the silky while hair of the patriarch.

Different species of Ragworts are quite numerous at high altitudes. They all have yellow flowers of various hues, shading from primrose to amber and orange; but the Golden Ragwort is the most abundant of them all. It is principally by their widely diverse foliage that the Senecios must be distinguished.

So bright and gay are these flowers, and all their fellows of golden mean, that we are compelled to wonder what caused Wordsworth, gentlest of poets and truest of Nature lovers, to write:

"Ill befall the yellow flowers, Children of the flaring hours."

What would the meadows be without the Dandelions, the Sunflowers, the Golden-rods, and the Arnicas? The land would lose much of its charm in Autumn did not these bril- 
liant blossoms blazon back the beams of the declining sun.

Senecio triangularis, or Giant Ragwort, is a large coarse species with closely set flower-heads and numerous long triangular leaves, strongly veined, and sharply toothed at the edges.

Senecio canus, or Silvery Groundsel, is exactly described by its name, for it has white silky stems and leaves and pale yellow flowers. It is a small plant and grows on the dry open meadows. The basal leaves are oblong and have even margins, while the tiny stem-leaves are slightly toothed.

Senecio lugens, or Black-tipped Groundsel, is so called on account of the conspicuous little black tips distinguishing the bracts of its involucres, or green cups, which hold up the deep amber-coloured flowers. The basal leaves are very long and toothed; the upper leaves cling closely to the stem, and are small, bract-like, and smooth.

Senecio pseudaureus, or Canada Ragwort, grows from one to two feet high from a creeping rootstock. The basal leaves are broadly ovate, somewhat cordate and serrate, and have long stalks, while the lower stem leaves are more or less lobed and the upper stem leaves are sessile. The rays are orange-yellow.

Senecio discoideus, or Northern Squaw-weed, is smooth except for small tufts of wool in the axils of the lower leaves. The stem is stout and the basal leaves are oval obtuse, thin, sharply toothed and abruptly narrowed into stalks longer than the blade; the stem leaves are few, small and more or less cut into narrow lobes. The flower heads grow in a loose flat-topped cluster and the rays are very short or none.

Senecio flavovirens, or Western Balsam Groundsel, is a slender pale yellow-green plant with tufts of wool at the 
base of the leaves, which are broadly oval, obtuse, crenate and taper into the stalks. The lower stem leaves are lanceolate in outline and the upper ones linear sessile and deeply pinnatifid. The flower heads have linear acute bracts with brownish tips and the rays are pale yellow or often lacking.

\section{COMMON DANDELION}

\section{Taraxacum officinale. Composite Family}

Scapes and leaves from the crown of a thick vertical root. Leaves: lanceolate in outline, and from irregularly dentate to runcinate-pinnatifid. Flowers: in solitary heads at the summit of the hollow scapes; rays numerous; involucre a single series of nearly equal narrow bracts, and several calyculate ones, the outer reflexed, all acute. Not indigenous.

"Common" as this Dandelion is named, and common as it is in all the mountain regions, yet it is far from being an ugly or even an uninteresting plant. On the contrary, its gorgeous golden blossoms render it extremely attractive. These blossoms consist of from one to two hundred strapshaped rays, their blunt tips notched into five teeth, which remind us that each ray-flower was once composed of five petals. The leaves are boldly cut into jagged lobes (supposed to resemble the teeth of a lion, hence the common name Dandelion, derived from the French Dent-de-lion), and these lobes are again cut into secondary points.

As the Dandelion grows old the rays fall off, and it bends downwards until the seed matures; then, elevating its head once more, it expands into a beautiful, snow-white, airy seed-ball, whose plumes blow away at the slightest puff and float off to find a new resting-place. This is an introduced plant.

Taraxacum rupestre, or Alpine Dandelion, is a tiny slender plant with finely cut leaves and small flowers, which 
seldom grows more than four or five inches high. From the lowlands to the highest levels this

"Dear common flower that grows beside the way, Fringing the dusty road with harmless gold,"

is to be found.

\section{SOW THISTLE}

Sonchus arvensis. Composite Family

Perennial by deep roots and creeping rootstocks. Stems: leafy below, paniculately branched and nearly naked above. Leaves: lower and basal runcinate-pinnatifid, spinulose-dentate. Flowers: heads several, corymbose-paniculate, bright yellow, very showy. Fruit: achenes oblong, compressed, with about ten rugose longitudinal ribs. Not indigenous.

Every traveller will easily recognize this common Sow Thistle, with its yellow or yellowish flowers and its very prickly leaves. Sometimes it is called Milk Thistle, on account of the milky juices contained in the stems. Like many of the members of the great family of Composites, the Sow Thistle has an involucre of green bracts, a flat naked receptacle, and numerous strap-shaped rays, which are truncate and finely toothed. It is a coarse showy weed, and opens its flowers early in the day, closing them again soon after noon. This is an introduced plant.

\section{LARGE-FLOWERED FALSE DANDELION}

Agoseris glauca. Composite Family

Stems: scape naked, slender, pubescent. Leaves: all basal, linear, lanceolate, crenulate, acuminate at the apex. Flowers: heads solitary, yellow; rays truncate, five-toothed.

A flower very like a real Dandelion, but with totally different foliage. The False Dandelion may always be distinguished by its long ribbon-like leaves, which grow up from the base of the plant and have slightly wavy margins. 


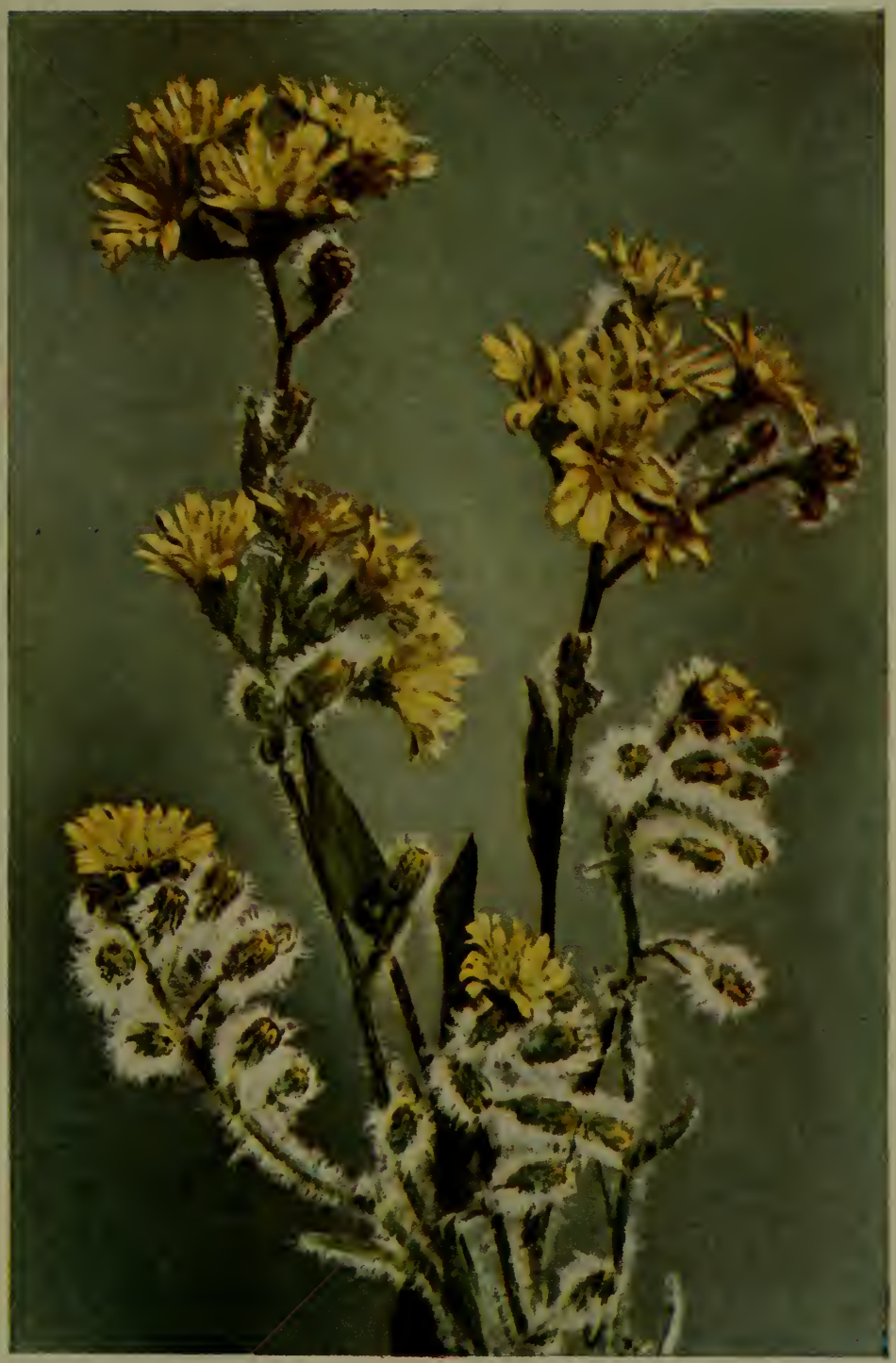

HAIRY HAWKWEED

(Hieracium Scouleri) 

Agoseris gracilcns, or Small-flowered False Dandelion, has lanceolate entire acute leaves and slender scapes ten to eighteen inches high which are woolly at the summit. The bracts of the involucre are narrow and smooth with hairyfringed margins, and the flowers are a beautiful deep orange.

Agoseris aurantiaca, or Copper False Dandelion, has deep copper-coloured flowers, which are occasionally purplish, otherwise it closely resembles the preceding species.

\section{MANY-FLOWERED HAWKSBEARD}

Crepis elegans. Composite Family

Stems: many from a tap-root, diffusely branched. Leaves: entire, or nearly so, radical ones spatulate, cauline ones lanceolate to linear. Flowers: in small numerous-clustered heads. Fruit: achenes linearfusiform, minutely scabrous on equal narrow ribs, attenuate into a short slender beak; pappus copious of very slender white bristles.

The Hawksbeards are all yellow, and their rays are squared and finely toothed at the tips, a characteristic which enables the traveller to at once distinguish them from the Arnicas, to which they bear a strong resemblance.

The Hawksbeards are not very pretty or very interesting flowers, yet they contribute their share of golden strands to Nature's summer carpet.

Crcpis nana, or Alpine Hawksbeard, is a small alpine species that grows at an altitude of 8000 feet, on barren rocky ground. It is a tiny plant, forming tufts and bearing many clusters of small flowers.

\section{HAIRY HAWKWEED}

Hieracium Scouleri. Composite Family

Pubescent with long crisp hairs, pale green. Stems: one to two feet high, very leafy. Leaves: lanceolate, sessile. Flowers: in a loose ir- 


\section{$362 \quad$ Yellow to Orange Flowers}

regular panicle; involucral bracts imbricated in two or three series; rays truncate, five-toothed at the apex.

A lovely plant! The pale green stems, leaves, and buds, thickly clothed with fine silvery hairs, and the brilliant golden flowers form an exquisite contrast, delighting the eye of the traveller. This Hawkweed is comparatively rare in the mountains.

Hieracium gracile, or Small Hawkweed, has tiny yellow or white flowers borne at the end of the long, slender, branching stems. They resemble miniature Dandelions and are very abundant. Like the Hawksbeards, the rays of the Hawkweeds are truncate, or cut off squarely at the ends, and finely toothed.

Hieracium umbellatum, or Narrow-leaved Hawkweed, has a tall, simple leafy stem and lanceolate, acute, usually entire, but occasionally toothed or lobed leaves narrowing to a sessile base, smooth above and hairy below, and fringed with marginal hairs. The few yellow flower heads are usually an inch broad and sub-umbellate. 


\section{GLOSSARY}





\section{GLOSSARY}

The object of these pages is to give as briefly as possible a simple explanation of those botanical terms most frequently used in describing plants.

\section{THE ROOT}

Rootstock: a creeping stem growing below the surface of the ground. Tuber: a thick portion of a rootstock, usually possessing eyes like a potato.

Corm: the thick fleshy base of a stem.

Bulb: an underground stem covered with scales.

Stolon: a basal branch, rooting at the nodes.

\section{THE STEM}

Erect: upright.

Simple: not branched.

Decumbent: horizontal on the ground, but vertical at the end.

Procumbent: flat on the ground.

Creeping: running along the earth and rooting at the joints.

Scape: the leafless flower-stalk of a stemless plant.

Node: the junction of two portions of the stem, often hard and swollen, at which leaves are usually borne.

\section{THE LEAF}

Bract: a leaf subtending a flower.

Incolucre: a circle of bracts round a flower, as in the Sunflower.

Entire: one the edge of which is not cut or lobed.

Simple: one which is not divided into leaflets.

Compound: one which is divided into leaflets.

Alternate: when one leaf grows just above the other on another side of the stem.

Opposite: when two appear at each joint, having the semicircle of the stem between them.

Whorled: when they grow in a circle round the stem.

Cordate: heart-shaped.

Obcordate: inversely heart-shaped. 
Linear: very narrow, like grass.

Lanceolate: narrow, tapering towards the top.

Oblanceolate: inversely lanceolate.

Ovate: egg-shaped, broader at the bottom.

Obovate: egg-shaped, broader at the top.

Elliptical: oblong, narrowed at the top and bottom.

Oval: broadly elliptical.

Spatulate: rounded at the top and narrow at the base.

Orbicular: round.

Reniform: nearly round, with a deep indentation at the stalk. Auriculate: having two rounded lobes at the base.

Sagittate: having two pointed lobes at the base.

Undulate: with wavy margins.

Crenate: with rounded teeth on margins.

Serrate: with sharp teeth on margins.

Incised: with deep jagged teeth.

Lobed: with divisions cut to about the middle.

Cleft: with divisions cut more than halfway into the leaf.

Divided: cleft to the midrib.

Pubescent: covered with fine hairs.

Glabrous: without any hairs, smooth.

Glaucous: covered with a bloom, as on the plum.

Mucronate: with a short sharp tip.

\section{THE FLOWER}

Calyx: the outer lower set of leaves at the base of the flower. Usually green, but sometimes bright coloured.

Sepals: the leaves of the calyx when it is divided to the base.

Corolla: the inner set of leaves of the flower.

Petals: the leaves of the corolla when it is divided to the base.

Perianth: said of a flower having only one set of floral leaves.

Pediccl: the small individual stalk of a flower borne in a cluster.

Peduncie: the main flower-stalk.

Sessile: said of flowers that grow close to the stem and have no pedicels. Raceme: a long-shaped flower-head formed by numerous flowers growing on pedicles along the sides of a common stalk.

Spike: a raceme with sessile flowers.

Head: a dense spike, globular in shape, like a Clover.

Corymb: a raceme with the lower flowers on longer stalks, so that the cluster is almost flat on the top, as in the Yarrow.

Umbcl: like a corymb, but with the pedicels all branching from a central point. 
Axillary: growing from the axil, or angle, formed by the leaf and the stem.

Stamens: composed of

Filament: the stalk to uphold the anther. Anther: a tiny box containing the pollen.

Pollen: the fertilizing powder of the plant.

Pistil: composed of

Ovary: containing the ovules, or undeveloped seeds.

Style: a slender stalk surmounting the ovary.

Stigma: a variously formed tip of the style, which has a rough moist surface to catch the pollen that fertilizes the seeds by means of minute tubes that penetrate the style and convey the pollen from the stigma to the ovules.

Spadix: a fleshy spike, as in the Arum Lily.

Spathe: the concave bract enveloping a spike.

\section{THE FRUIT}

Achene: a dry one-seeded fruit.

Berry: a pulpy fruit.

Capsule: a dry fruit with two or more carpels.

Drupe: a single fruit, with a fleshy outer wall and a bony inner wall.

Plumose: resembling a plume, like the Clematis in seed.

Sterile: without seed. 



\section{INDEX TO SCIENTIFIC NAMES}

Abies lasiocarpa, 67

Acer glabrum, 78

Achillea borealis, I99

Achillea lanulosa, I98

Actæa rubra, I3I

Actæa rubra forma neglecta, I3I

Adiantum pedatum, 49

Agoseris aurantiaca, 360

Agoseris glauca, 360

Agoseris gracilens, 360

Allium cernuum, 205

Allium Schœnoprasum

biricum, 257

Allotropa virgata, I75

Alnus sinuata, 77

Alnus sitchensis, 77

Amelanchier Cusickii, I54

Amelanchier florida, I 52

Anaphalis margaritacea, I98

Androsace chamæjasme, 185

Androsace diffusa, 185

Androsace septentrionalis, I85

Anemone Drummondii, I28

Anemone multifida, 126

Anemone occidentalis, I26

Anemone parviflora, 128

Anemone patens var. Wolfgangiana, 259

Antennaria alpina, I97

Antennaria Howellii, I96

Antennaria lanata, 197

Antennaria media, I97

Antennaria parvifolia, 197

Antennaria pulcherrima, I97

Antennaria racemosa, 196

Antennaria rosea, 250

Apocynum androsæmifolium, 239

Aquilegia brevistyla, 26I
Aquilegia flavescens, 3I 7

Aquilegia formosa, 213

Arabis Drummondii, I36

Arabis hirsuta, I 36

Arabis Hobœllii, I36

Arabis glabra, I36

Arabis Lyallii, 2I6

Aralia nudicaulis, I67

Arceuthobium americanum, II6

Arctostaphylos alpina, 234

Arctostaphylos tomentosa, 234

Arctostaphylos Uva-ursi, 232

Arenaria capillaris var. nardifolia, I2I

Arenaria lateriflora, I2I

Arenaria sajanensis, I2I

Arenaria verna var. propinqua,

I 2 I

Arnica alpina, 354

Arnica Chamissonis, 354

Arnica cordifolia, 353

Arnica fulgens, 356

Arnica gracilis, 356

Arnica latifolia, 354

Arnica louiseana, 356

Arnica Parryi, 356

Artemisia biennis, 200

Artemisia discolor, 200

Artemisia frigida, 199

Aruncus sylvester, 152

Aspidium Filix-mas, 53

Aspidium Oreopteris, 53

Aspidium spinulosum var. dilatata,

\section{3}

Asplenium cyclosorum, 5I

Asplenium viride, 5I

Aster alpinus, I95

Aster ciliomarginatus, 298 
Aster commutatus, 194

Aster conspicuous, 294, 296

Aster Engelmanni, 297

Aster Fremonti, 296

Aster frondeus, 296

Aster lævis, 297

Aster Lindleyanus, 297

Aster major, 298

Aster Richardsonii, 297

Aster sibiricus, 298

Astragalus aboriginorum, I6I

Astragalus adsurgens, 264

Astragalus alpinus, 267

Astragalus convallarius, 267

Astragalus hypoglottis, 267

Astragalus Macounii, 267

Astragalus tenellus, I6I

Berberis aquifolium, $3 \mathrm{I} 8$

Berberis repens, 318

Betula alba. var. papyrifera, 76

Betula fontinalis, 76

Betula glandulosa, 76

Boschniakia strobilacea, 29I

Botrychium lanceolatum, 55

Botrychium Lunaria, 55

Botrychium simplex, 55

Botrychium virginianum, 55

Boykinia occidentalis, I 39

Brassica Sinapistrum, 322

Braya humilis, I35

Bromus Richardsonii var. pallidus, 82

Bryanthus empetriformis, 230

Bryanthus glanduliflorus, I 82

Bryanthus intermedius, 232

Calamagrostis canadensis, 82

Callitriche palustris, I63

Calochortus Lyallii, 98

Calochortus macrocarpus, 96

Caltha leptosepala, I29

Caltha palustris, 3I 7

Calypso bulbosa, 209

Campanula lasiocarpa, 294
Campanula rotundifolia, 29r

Capsella Bursa-pastoris, I34

Cardamine bellidifolia, 136

Cardamine pennsylvanica, I35

Carduus foliosus, 201

Carduus Kelseyi, 201

Carduus undulatus, 300

Carex festiva, 85

Carex Mertensii, 85

Carex nigricans, 86

Carex pyrenaica, 85

Carex rupestris, 86

Cassiope Mertensiana, I83

Cassiope tetragona, $I 83$

Castilleja angustifolia var. Bradburii, 245

Castilleja lancifolia, 245

Castilleja miniata, 243

Castilleja oreopala, 246

Castilleja pallida, 244

Castilleja purpurascens, 244

Castilleja rupicola, 246

Cerastium alpinum, 122

Cerastium arvense, 122

Cheilanthes Féei, 50

Chenopodium album, I20

Chenopodium capitatum, I20

Chimaphila Menziesii, 226

Chimaphila umbellata, 225

Chrysanthemum Leucanthemum, I99

Chrysopsis hispida, 346

Chrysopsis villosa, 346

Chrysosplenium tetrandrum, 326

Cichorium Intybus, 30I

Circaea alpina, 166

Circaea pacifica, 166

Claytonia lanceolata, I24

Claytonia megarrhiza, I25

Claytonia parvifolia, I25

Clematis columbiana, 260

Clematis ligusticifolia, 128

Clintonia uniflora, 98

Collinsia tenella, 286

Comandra livida, II 4

Comandra pallida, II4 
Comandra Richardsiana, I 6

Corallorhiza maculata, I 3

Corallorhiza Mertensiana, I I4

Corallorhiza striata, II4

Corallorhiza trifida, II3

Cornus canadensis, I72

Cornus stolonifera, 172

Corydalis aurea, 319

Crepis elegans, 36r

Crepis nana, 36I

Cryptogramma acrostichoides, 50 Cryptogramma Stelleri, 5I

Cypripedium parviflorum, 312

Cypripedium passerinum, 105

Cypripedium pubescens, 3I I

Cystopteris fragilis, 53

Cystopteris montana, 53

Delphinium bicolor, 262

Delphinium Brownii, 26I

Delphinium Menziesii, 262

Dicentra formosa, 215

Dicentra uniflora, 21 5

Disporum oreganum, I02

Disporum trachycarpum, 102

Dodecatheon pauciflorum, 238

Draba alpina, 320

Draba aurea, 320

Draba glacialis, 320

Draba incana, I 33

Draba lonchocarpa, I33

Draba nivalis, 320

Draba præalta, I33

Dracocephalım parviflorum, $28_{4}$

Drosera longifolia, I38

Drosera rotundifolia, 137

Dryas Drummondii, 33I

Dryas octopetala, 158

Elaeagnus argentea, 334

Empetrum nigrum, 272

Epilobium adenocaulon, 225

Epilobium alpinum, I64

Epilobium ånagallidifolium, 224

Epilobium angustifolitum, 223

Epilobium clavatum, 225
Epilobium Hornemanni, 224

Epilobium latifolium, 224

Epilobium luteum, 336

Epilobium paniculatum, 225

Epipactis decipiens, I Io

Epipactis repens, II2

Equisetum arvense, 56

Equisetum fluviatile, 56

Equisetum hyemale, 57

Equisetum pratense, 56

Equisetum scirpoides, 56

Equisetum sylvaticum, 56

Equisetum variegatum, 57

Erigeron acris, 298

Erigeron aureus, 350

Erigeron cæspitosus, 196

Erigeron compositus, 195

Erigeron glabellus, 250

Erigeron lanatus, 299

Erigeron melanocephalus, 195

Erigeron multifidus, I95

Erigeron philadelphicus, 299

Erigeron salsuginosus, 299

Erigeron uniflorus, 299

Eriogonum androsaceum, II7

Eriogonum ovalifolium, I17

Eriogonum umbellatım, I16

Eriophorum angustifolium, 85

Eriophorum callitrix, 83

Erysimum parviflorum, 324

Erythronium grandiflorum, 309

Erythronium grandiflorum var. parviflorum, 3I I

Erythronium montanum, 96

Fatsia horrida, I68

Festuca ovina, 82

Fragaria bracteata, I54

Fragaria glanca, I54

Fritillaria pudica, 309

Gaillardia aristata, 353

Galium boreale, I9I

Galium trifidum, 192

Galium triflorum, I9I

Gaultheria humifusa, I85 
Gaultheria ovatifolia, 183

Gentiana affinis, 278

Gentiana Amarella, var. acuta, 276

Gentiana arctophila, 276

Gentiana glauca, 278

Gentiana Macounii, 275

Gentiana propinqua, 276

Gentiana prostrata, 276

Geranium Bicknellii, 223

Geranium carolinianum, 222

Geranium Richardsonii, I63

Geum macrophyllum, 330

Geum strictum, 330

Geum triflortim, 218

Gilia aggregata, 239

Habenaria bracteata, Io9

Habenaria dilatata, 106

Habenaria gracilis, I09

Habenaria hyperborea, Iog

Habenaria obtusata, I09

Habenaria orbiculata, I Io

Halenia deflexa, 278

Hedysarum boreale, 270

Hedysarum Mackenzii, 222

Hedysarum sulphurescens, I6I

Helianthus giganteus, $35 \mathrm{I}$

Heracleum lanatum, I 70

Heuchera glabella, I46

Heuchera glabra, I 46

Heuchera ovalifolia, I44

Hieracium gracile, 36I

Hieracium Scouleri, 36 I

Hieracium umbellatum, 36I

Hippuris montana, I67

Hippuris vulgaris, 167

Hordeum jubatum, 82

Hypericum Scouleri, 332

Juncus Drummondii, 86

Juncus Mertensianus, 86

Juncus Parryi, 86

Juncus triglumis, 86

Juniperus communis var. montana, 73

Juniperus horizontalis, 73
Juniperus scopulorum, 73

Kalmia polifolia, 230

Kobresia Bellardi, 85

Kobresia bipartita, 85

Kruhsea streptopoides, 207

Lappula diffusa, 28r

Lappula echinata, 28I

Lappula floribunda, 280

Larix Lyallii, 63

Lathyrus ochroleucus, $\mathbf{I}_{3}$

Lathyrus palustris, 27 I

Ledum glandulosum, I8o

Ledum grœnlandicum, I79

Lepidium apetalum, I34

Leptarrhena amplexifolia, I28

Leptotaenia multifida, 274

Ligusticum apiifolium, 170

Ligusticum Grayi, I 70

Lilium columbianum, 307

Lilium montanum, 305

Linnaea borealis var. americana, 249

Linum Lewisii, 27 I

Listera convallarioides, II 2

Listera cordata, II 2

Lithophragma tenella, 216

Lithospermum angustifolium, 339

Lithospermum ruderale, 340

Lobelia Kalmii, 294

Loiseleuria procumbens, 229

Lomatium macrocarpum, I 70

Lomatium Martindalei var. angustatum, 339

Lomatium triternatum, 338

Lonicera glaucescens, 248

Lonicera involucrata, 343

Lonicera utahensis, 344

Lupinus subalpinus, 264

Lutkea pectinata, I $_{2}$

Luzula parviflora, 87

Luzula spicata, 87

Lychnis apetala, 123

Lychnis Drummondii, 123

Lycopodium alpinum, 57 
Lycopodium annotinum, 57

Lycopodium clavatum, 57

Lycopodium complanatum, 58

Lycopodium Selago, 57

Lycopodium sitchense, 57

Lysichiton kamtschatcense, 305

Melilotus officinalis, 33I

Mentha canadensis, 285

Mentha canadensis var. lanata, 286

Menyanthes trifoliata, I86

Menziesia ferruginea, 229

Menziesia glabella, 228

Mertensia oblongifolia, 283

Mertensia paniculata, 283

Mimulus alpina, 34I

Mimulus Langsdorfii, 340

Mimulus Lewisii, 240

Mimulus moschatus, 34I

Mitella Breweri, I46

Mitella nuda, I 48

Mitella pentandra, I48

Mitella trifida, 148

Monoarda fistulosa, 240

Moneses uniflora, I74

Monotropa Hypopitys, 176

Monotropa uniflora, 176

Myosotis alpestris, 282

Myriophyllum spicatum, 166

Neslia paniculata, 322

Newberrya congesta, I 78

Nymphaea polysepala, 313

Oenothera biennis, 337

Orchis rotundifolia, 207

Orobanche fasciculata, 29I

Orobanche uniflora, 290

Orthocarpus luteus, 34I

Osmorhiza divaricata, I68

Osmorhiza obtusa, 168

Oxyria digyna, I 7

Oxytropis deflexa, 269

Oxytropis Lamberti, 332

Oxytropis monticola, 332

Oxytropis podocarpa, 269
Oxytropis splendens, 269

Oxytropis viscida, 267

Pachistima Myrsinites, I64

Papaver alpinum, 3 I9

Parnassia fimbriata, I49

Parnassia Kotzebuei, 149

Parnassia montanensis, I48

Parnassia parviflora, I 49

Pedicularis bracteosa, 246

Pedicularis contorta, 189

Pedicularis grœnlandica, 247

Pedicularis racemosa, I 89

Pellæa atropurpurea, 50

Penstemon confertus, 340

Penstemon fruticosus, 286

Penstemon humilis, 287

Penstemon Menziesii, 287

Penstemon procerus, 287

Petasites frigidus, 200

Petasites palmatus, 200

Petasites sagitatus, 200

Phaca americana, I6

Phacelia heterophylla, 280

Phacelia sericea, 279

Phegopteris alpestris, 47

Phegopteris Dryopteris, 47

Phegopteris polypodioides, 47

Phleum alpinum, 82

Phlox Douglasii, 239

Physaria didymocarpa, 320

Picea canadensis, 65

Picea Engelmanni, 67

Pinguicula vulgaris, 289

Pinus albicaulis, 6I

Pinus contorta var. Murrayana, 63, I 6

Pinus monticola, 62

Pinus ponderosa, 62

Plantago major, 189

Plantago major var. asiatica, I9I

Poa alpina, 82

Polemonium confertum, 279

Polemonium humile, 279

Polygonum bistortoides, I20

Polygonum Mullenbergii, 210 
Polygonum viviparum, I I8

Polystichum Lonchitis, 52

Populus acuminata, 76

Populus balsamifera, 75

Populus tremuloides, 75

Populus trichocarpa, 75

Potamogeton filiformis, 9I

Potamogeton Richardsonii, 9I

Potentilla Anserina, 327

Potentilla arguta, 156

Potentilla dissecta, 328

Potentilla dissecta var. glaucophylla, 328

Potentilla dissecta var. multisecta, 328

Potentilla dissecta var. pinnatisecta, 328

Potentilla fruticosa, 329

Potentilla gracilis, 329

Potentilla Hippiana, 328

Potentilla nivea, 329

Potentilla norvegica, 328

Potentilla palustris, 156,263

Potentilla uniflora, 329

Primula farinosa, 237

Primula Maccalliana, 237

Prunella vulgaris, 284

Prunus demissa, 78

Pseudotsuga taxifolia, $7 \mathrm{I}$

Pteris aquilina var. lanuginosa, 49

Pterospora andromedea, I78

Pyrola asarifolia, 226

Pyrola asarifolia var. incarnata, 228

Pyrola chlorantha, I74

Pyrola minor, I75

Pyrola secumda, I75

Pyrus sambucifolia, 77

Radicula Nasturtium-aquaticum, I35

Ranunculus acris, $3 \mathrm{I} 4$

Ranunculus aquatilis, 316

Ranunculus Cymbalaria, 3I 5

Ranunculus Eschscholtzii, 3I5

Ranunculus Macounii, 3I5
Ranunculus pygmæus, 316

Ranunculus repens, 316

Ranunculus reptans, 316

Rhinanthus Crista-galli, 342

Rhododendron albiflorum, 180

Ribes hudsonianum, I50

Ribes lacustre, I50

Ribes laxiflorum, 2I7

Ribes setosum, I49

Romanzoffia sitchensis, 187

Rosa acicularis, 219

Rosa gymnocarpa, 22I

Rosa Macounii, 220

Rubus arcticus, 218

Rubus parviflorus, I $_{5} 6$

Rubus pedatus, 158

Rubus spectabilis, 219

Rubus strigosus, 158

Rubus triflorus, ${ }_{58} 8$

Rudbeckia hirta, 35I

Rumex Acetosa, II 8

Rumex Acetosella, II8

Rumex salicifolius, II 8

Salix arctica, 75

Salix Barclayi, 74

Salix Barrattiana, 74

Salix Bebbiana, 74

Salix candida, 73

Salix nivalis, 74

Salix petrophila, 74

Salix sitchensis, 75

Salix vestita, 74

Sambucus melanocarpa, 193

Sambucus racemosa, 193

Saussurea densa, 300

Saxifraga adscendens, I42

Saxifraga æstivalis, 142

Saxifraga aizoides, 326

Saxifraga bronchialis, I39

Saxifraga cæspitosa, I42

Saxifraga cernua, I40

Saxifraga Lyallii, I40

Saxifraga Mertensiana, I42

Saxifraga nivalis, I42

Saxifrnaga nuțana, I40 
Saxifraga oppositifolia, 2I I, 262

Saxifraga rivularis, I44

Sedum roseum, 216

Sedum stenopetalum, 324

Selaginella rupestris, 58

Selaginella selaginoides, 58

Senecio Balsamitæ, 357

Senecio canus, $35^{8}$

Senecio discoideus, 358

Senecio flavovirens, 358

Senecio lugens, 358

Senecio pseudaureus, 358

Senecio triangularis, 358

Shepherdia canadensis, 336

Sibbaldia procumbens, 327

Silene acaulis, 2I I, 262

Silene Lyallii, I24

Silene Macounii, I23

Sisymbrium altissimum, 323

Sisymbrium canescens, 323

Sisymbrium Hartwegianum, 323

Sisymbrium incisum, 323

Sisyrinchium angustifolium, 257

Sisyrinchium californicum, 3I I

Sisyrinchium idahoense, 259

Sisyrinchium septentrionale, 259

Smilacina amplexicaulis, Ior

Smilacina stellata, Ior

Solidago canadensis, 346

Solidago decumbens, 348

Solidago elongata, 350

Solidago missouriensis, 348

Solidago multiradiata, 348

Solidago nemoralis, 348

Sonchus arvensis, 360

Sparganium simplex, 8I

Spiraea densiflora, 217

Spiraea lucida, I50

Spiranthes Romanzoffiana, I Io

Stachys palustris, 285

Stellaria borealis, I 22

Stellaria longipes, I2I

Stenanthium occidentale, 92

Streptopus amplexifolius, 102, I05, 207

Streptopus roseus, 205
Symphoricarpus racemosus var. pauciflorus, 192

Taraxacum officinale, 359

Taraxacum rupestre, 359

Taxus brevifolia, 6I

Tellima grandiflora, I46

Thalictrum megacarpum, I 26

Thalictrum occidentale, I25

Thlaspi arvense, I33

Thuya plicata, $7 \mathrm{I}$

Tiarella unifoliata, 144

Tofieldia glutinosa, 9I

Tofieldia occidentalis, 9I

Tofieldia palustris, 9I

Trientalis arctica, $\mathbf{\$} 6$

Trifolium hybridum, I6o

Trifolium pratense, 22I

Trifolium repens, I60

Triglochin palustris, 82

Trollius laxus var. albiflorus, I29

Tsuga heterophylla, 69

Tsuga Mertensiana, 69

Typha latifolia, 8r

Urtica Lyallii, I 44

Utricularia intermedia, 343

Utricularia vulgaris, 342

Vaccinium cæspitosum, 236

Vaccinium erythrococcum, 236

Vaccinium membranaceum, 235

Vaccinium ovalifolium, 235

Vaccinium Oxycoccus, 236

Vaccinium Vitis-idæa, 236

Valeriana Scouleri, 250

Valeriana septentrionalis, I94

Valeriana sitchensis, 194

Veratrum viride, 94

Veronica alpina var. unalaschensis, 288

Veronica americana, 289

Veronica humifusa, 289

Viburnum pauciflorum, I93

Vicia americana, 270

Vicia Cracca, 270 
Viola adunca, 274

Viola canadensis, 164

Viola glabella, 333

Viola nephrophylla, 272

Viola orbiculata, 334

Viola palustris, 274
Viola Selkirkii, 274

Viola sempervirens, 334

Zizia cordata, 338

Zygadenus elegans, 92

Zygadenus venenosus, 94 


\section{INDEX TO ENGLISH NAMES}

Adder's Tongue, Mountain, 96

Adder's Tongue, Small Yellow, 3I I

Adder's Tongue, Yellow, 309, 3ro Alder, Mountain, 77

Alder, Speckled, 77

Alexanders, Heart-leaved, 338

Allotropa, Striped, I75

Alum-root, Bristly, I 46

Alum-root, Oval-leaved, I44

Alum-root, Smooth, I 46

Androsace, Alpine, 185

Androsace, Spreading, I85

Androsace, Sweet, I85

Anemone, Alpine, I28

Anemone, Few-flowered, I28

Angelica, Cut-leaved, 274

Arnica, Alpine, 354

Arnica, Broad-leaved, 354

Arnica, Chamisso's, 354

Arnica, Heart-leaved, 353

Arnica, Notched, 357

Arnica, Parry's, 357

Arnica, Schaeffer's, 357

Arnica, Slender, 357

Arrow-wood, I93

Asphodel, Glutinous, 9I

Asphodel, Scottish, 9I

Asphodel, Western, 9I

Aster, Alpine, I95

Aster, Engelmann's, 297

Aster, Fremont's, 296

Aster, Golden, 346

Aster, Golden Hairy, 346

Aster, Great Northern, 298

Aster, Hairy-margined, 298

Aster, Large Purple, 294

Aster, Leafy-bracted, 296
Aster, Lindley's, 297

Aster, Richardson's, 297

Aster, Smooth, 297

Aster, Violet, 298

Aster, White, I94

Avens, Large-leaved, 330

Avens, Long-plumed, 218

Avens, Yellow, 330

Azalea, Trailing Alpine, 229

Balm of Gilead, 75

Baneberry, Red, I3I

Baneberry, White, I3I

Bearberry, Alpine, 234

Bearberry, Red, I31, 232

Beard-tongue, Blue, 287

Beard-tongue, Large Purple, 286

Beard-tongue, Slender, 287

Beard-tongue, Small-leaved, 287

Beard-tongue, Yellow, 340

Bedstraw, Northern, 19I

Bedstraw, Small, I92

Bedstraw, Sweet-scented, I9I

Bergamot, Wild, 240

Betony, Western Wood, 246

Bilberry, Alpine, 236

Bilberry, Dwarf, 236

Bilberry, Mountain, 236

Birch, Black, 76

Birch, Dwarf, 76

Birch, Paper, 76

Bishop's Cap, I48

Bistort, Alpine, i I8

Bistort, Heart-leaved, I20

Bitter-root, 21 3

Black-eyed Susan, 35I

Bladder-pod, 320

Bladderwort, Greater, 342 
Bladderwort, Yellow, 343

Bleeding-heart, One-flowered, 215

Bleeding-heart, Wild, 2I 5

Blueberry, Black, 235

Blueberry, Oval-leaved, 235

Blue-eyed Grass, Small, 259

Blue-eyed Grass, Stiff, 257, 258

Blue-eyed Grass, Twisted, 259

Blue-eyed Grass, Yellow, 3I I

Blue-eyed Mary, 286

Boschniakia, 29I

Bottle Brush, I67

Boykinia, Western, I39

Bracken, Common, 49

Brake, Purple Cliff, 50

Brake, Nootka Rock, 50

Brake, Slender Rock, 5I

Bronze Bells, 92

Brown-eyed Susan, 353

Buckbean, Marsh, I86

Buffaloberry, Canada, 336

Bunchberry, I72

Bur-reed, Simple-stemmed, 8I

Burseed, 28I

Buttercup, Macoun's, 315

Buttercup, Meadow, 3I4

Buttercup, Pigmy, 3 I6

Buttercup, Snow, 3I5

Butterwort, 289, 290

Calypso, 209

Campion, Moss, 21 I, 262

Campion, White, I23

Cancer-root, Naked, 29r

Cancer-root, One-flowered, 290

Capberry, 156

Catchfly, Lyall's, I24

Cat-tail, Broad-leaved, 8I

Cedar, Red, $7 \mathrm{I}$

Chalice Cup, I26

Cherry, Western Choke, 78, I 54

Chickweed, Alpine Mouse-ear, I22

Chickweed, Field Mouse-ear, I22

Chicory, 301

Christmas Green, Trailing, 58

Cinquefoil, Alpine, 329
Cinquefoil, Common, 328

Cinquefoil, Dissected, 328

Cinquefoil, Graceful, 329

Cinquefoil, Leafy, 328

Cinquefoil, One-flowered, 329

Cinquefoil, Purple, 263

Cinquefoil, Rough, 328

Cinquefoil, Shrubby, 329

Cinquefoil, Smooth, 328

Cinquefoil, Tall, I56

Cinquefoil, Woolly, 328

Clematis, Purple, 260

Clematis, White, I28

Clover, Alsatian, I6o

Clover, Red, 22I

Clover, White, I6o

Club Moss, Alpine, 57

Club Moss, Arctic, 57

Club Moss, Creeping, 57

Club Moss, Fir, 57

Club Moss, Stiff, 57

Columbine, Blue, 26r

Columbine, Western, 2I3, 2I 4

Columbine, Yellow, 317, 318

Coltsfoot, Arctic, 200

Coltsfoot, Arrow-leaved, 200

Coltsfoot, Palm-leaved, 200

Comandra, Green, II6

Comandra, Swamp, i I4

Comandra, White, I I4

Coral Root, Early, II3

Coral Root, Spotted, II4

Coral Root, Spurred, II 4

Coral Root, Striped, II4

Corydalis, Golden, 3 I9

Cottonwood, 76

Cranberry, Small, 236

Crane's Bill, Carolina, 222

Cress, Drummond's Rock, I36

Cress, Hairy Rock, I36

Cress, Lyall's Rock, 216

Cress, Northern Rock, I35

Cress, Smooth Rock, I 36

Cress, Stony Rock, I36

Cress, Alpine Bitter, I36

Cress, Penny, I33 
Cress, Water, 135

Cress, White Bitter, I35, I36

Crowberry, 272

Crowfoot, Creeping, 3I5

Crowfoot, Water, 316

Crowfoot, Yellow, 316

Currant, Black, I 50

Currant, Skunk, 2I 7

Daisy, Ox-eye, 199

Dandelion, Alpine, 359

Dandelion, Common, 359

Dandelion, Copper False, 36r

Dandelion, Large-flowered False, 360

Dandelion, Small-flowered False, 36I

Devil's Club, I68

Disporum, Woolly, I02

Dock, Willow-leaved, i 8

Dogbane, Spreading, 239

Dogwood, Red-osier, I72

Dragon Head, 284

Dryas, Drummond's, 33I

Elder, Black-berried, I93

Elder, Red-berried, 193

Elephant's Head, 247

Elyna, Arctic, 85

Enchanter's Nightshade, Pacific, I66

Enchanter's Nightshade, Small, I66

Eriogonum, Dwarf, I I 7

Eriogonum, Silvery, II 7

Eriogonum, Tall, I 6

Evening Primrose, Common, 337

Everlasting, Alpine, I97

Everlasting, Arctic, 197

Everlasting, Mountain, I97

Everlasting, Mouse-ear, I96

Everlasting, Pearly, 198

Everlasting, Pink, 250

Everlasting, Silky, I97

Everlasting, Tall, I97

Everlasting, White, I96
Fairy Bells, 102

Fennel, Water, I63

Fern, Brittle, 53

Fern, Holly, 52

Fern, Large Lady, 5I

Fern, Long Beech, 47

Fern, Male Shield, 53

Fern, Mountain Bladder, 53

Fern, Oak, 47

Fern, Rattlesnake, 55

Fern, Scaly Shield, 53

Fern, Slender Lip, 50

Fern, Spinulose Shield, 53

Fern, Tufted Beech, 47

Fir, Balsam, 67

Fir, Douglas, 7I

Flax, Wild, $27 \mathrm{I}$

Fleabane, Alpine, 299

Fleabane, Arctic, 299

Fleabane, Black-woolly, 195

Fleabane, Blue, 298

Fleabane, Daisy, I95

Fleabane, Fern-leaved, I95

Fleabane, Large Purple, 299

Fleabane, Lavender, 299

Fleabane, Rough, 250

Fleabane, Tufted, I 96

Fleabane, Yellow, 350

Forget-me-not, False, 28o

Forget-me-not, Mountain, 282

Fritillary, Yellow, 309

Garlic, Pink, 205

Garlic, Purple, 257

Gaultheria, Creeping, I85

Gaultheria, Red-berried, 183

Gentian, Alpine, 276

Gentian, Dwarf, 276

Gentian, Four-parted, 276

Gentian, Large, 278

Gentian, Macoun's, 275

Gentian, Northern, 276

Gentian, Pale, 278

Gentian, Spurred, 278

Geranium, Bicknell's, 223

Geranium, White, I63 
Gilia, Scarlet, 239

Globe Flower, White, 129

Goat's Beard, 152

Golden-rod, Canada, 346, 347

Golden-rod, Field, 348

Golden-rod, Gray, 348

Golden-rod, Mountain, 348

Golden-rod, Northern, 348

Golden-rod, Slender, 350

Gooseberry, Bristly, 149

Gooseberry, Swamp, I50

Grape, Oregon, 3I8

Grape, Rocky Mountain, 318

Grass, Alpine Spear, 82

Grass, Blue-joint, 82

Grass, Cotton, 85

Grass, Fringed Brome, 82

Grass, Marsh Arrow, 82

Grass, Pepper, I34

Grass, Sheep's Fescue, 82

Grass, Squirrel-tail, 82

Grass, Alpine Whitlow, 320

Grass, Arctic Whitlow, 320

Grass, Golden Whitlow, 320

Grass, Long-podded Whitlow, I33

Grass, Pale Yellow Whitlow, 320

Grass, Spring Whitlow, I33

Grass, White Whitlow, I 33

Grass of Parnassus, Alpine, 149

Grass of Parnassus, Fringed, I49

Grass of Parnassus, Marsh, I 48

Grass of Parnassus, Snill, I49

Greek Valerian, Blue, 279

Greek Valerian, Purple, 279

Groundsel, Black-tipped, 358

Groundsel, Silvery, 358

Groundsel, Western Balsam, $35^{8}$

Hare's Tail, 83

Harebell, 291, 292

Harebell, Arctic, 294

Hawksbeard, Alpine, 36r

Hawksbeard, Many-flowered, 36r

Hawkweed, Hairy, 36r

Hawkweed, Narrow-leaved, 362

Hawkweed, Small, 362
Heart-of-the-earth, 284

Heath, White, 183

Heath, Four-angled, 183

Heather, Pink Mountain, 232

Heather, Red Mountain, 230

Heather, White Mountain, I 82

Hedysarum, Mackenzie's, 222

Hedysarum, Purple, 270

Hedysarum, White, I6r

Heliotrope, Canada, 250, 253

Heliotrope, Northern, 194

Heliotrope, Wild, I94

Hellebore, Indian, 94

Hemlock, Mountain, 69

Hemlock, Western, 69

Herb of St. Barbara, 322

Honeysuckle, Smooth-leaved, 248

Honeysuckle, Bush Fly, 344

Honeysuckle, Involucred Fly, 343, 344

Horsetail, Field, 56

Horsetail, Swamp, 56

Horsetail, Thicket, 56

Horsetail, Variegated, 57

Horsetail, Wood, 56

Indian Pipe, 176

Juniper, Alpine, 73

Juniper, Creeping, 73

Juniper, Rocky Mountain, 73

Kobresia, Arctic, 85

Labrador Tea, Smooth-leaved, I8o

Labrador Tea, Woolly, I79

Ladies Tresses, Hooded, I Io

Lady's Slipper, Large Yellow, 3I I, 3 I 2

Lady's Slipper, Small Yellow, 312

Lamb's Quarters, I20

Larch, Lyall's, 63

Larkspur, Blue, 262

Larkspur, Blue-veined, 262

Larkspur, Mountain, 26I

Laurel, Swamp, 230 
Leptarrhena, 138

Lily, Green, 92

Lily, Mountain, 305

Lily, Poisonous Green, 94

Lily, Western, 307

Lobelia, Brook, 294

Locoweed, 332

Lousewort, Contorted, 189

Lousewort, White, I89

Lovage, Fern-leaved, I 70

Lovage, Gray's, I70

Lungwort, Blue, 283

Lungwort, Tall, 283

Lupin, Alpine, 264

Maidenhair, 49

Manzanita, 234

Maple, Dwarf, 78

Mare's Tail, Mountain, 167

Mariposa, Green-banded, 96

Mariposa, Pale, 98

Marsh-marigold, 3 I 7

Marsh-marigold, Alpine, 129

Meadow Rue, Veiny, I25

Meadow Rue, Western, I25

Melilot, Yellow, 33I

Menziesia, Scaly, 229

Menziesia, Smooth, 228

Milfoil, Spiked Water, I66

Mint, Canada, 285

Mint, Hairy, 286

Mist Maidens, I87

Mitrewort, 146, I48

Mitrewort, Alpine, 148

Mitrewort, Five-stamened, I48

Moccasin Flower, White, I05

Monkey Flower, Alpine, 34I

Monkey Flower, Red, 240, 242

Monkey Flower, Yellow, 340

Moonwort, 55

Moonwort, Slender, 55

Moonwort, Small, 55

Mountain Ash, Western, 77

Mountain Lover, I64

Musk Flower, 34I

Mustard, Tall Hedge, 323
Mustard, Hartweg's Tansy, 323

Mustard, Tall Tansy, 323

Mustard, Treacle, 324

Mustard, Western Tansy, 323

Nancy-over-the-ground, I44, I48

Neslia, 322

Nettle, Common, II4

Newberrya, I78

Orchis, Fly-spotted, 207

Orchis, Graceful Rein, 109

Orchis, Leafy Rein, I09

Orchis, Long-bracted Rein, I09

Orchis, Northern Rein, I09

Orchis, Round-leaved Rein, I Io

Orchis, White Rein, I06

Oreobroma, Striped, 2I3

Oxytrope, Alpine, 267

Oxytrope, Drooping-fruited, 269

Oxytrope, Inflated, 269

Oxytrope, Mountain, 332

Oxytrope, Showy, 269

Paint Brush, Lance-leaved Indian, 245

Paint Brush, Purple Indian, 244

Paint Brush, Red Indian, 243

Paint Brush, White Indian, 244

Painted Cup, Bradbury's, 245

Painted' Cup, Bright, 246

Painted Cup, Magenta, 246

Parsley, Large-seeded, I70

Parsley, Martindale's, 339

Parsley, Narrow-leaved, 338

Parsnip, Cow, I70

Pasque Flower, 259

Pelican Flower, 34I

Persicaria, Swamp, 210

Phacelia, Blue, 280

Phacelia, Mountain, 279

Phlox, Alpine, 239

Pine, Bull, 62

Pine, Lodge Pole, 63

Pine, Mountain, 62

Pine, White-bark, 6I 
Pine Drops, I78

Pinesap, 176

Pink, Drummond's, I23

Pink, Nodding, I23

Pipsissewa, 225

Plantain, Asiatic, I9I

Plantain, Common, I89

Plantain, Stout Rattlesnake, I Io

Plantain, Small Rattlesnake, I I2

Pond Lily, Yellow, 3I3

Pondweed, Filiform, 9I

Pondweed, Richardson's, 9I

Poplar, Aspen, 75

Poplar, Western Balsam, 75

Poppy, Arctic, 319

Primrose, Bird's Eye, 237

Primrose, Dwarf Canada, 237

Prince's Pine, Spotted, 226

Puccoon, Hairy, 340

Puccoon, Narrow-leaved, 339

\section{Queen Cup, 98}

Ragwort, Canada, 358

Ragwort, Giant, $35^{8}$

Ragwort, Golden, 357

Rattle, Yellow, 342

Raspberry, Arctic, 218

Raspberry, Creeping, I 58

Raspberry, Dwarf, I 58

Raspberry, Red, I58

Rhododendron, Mountain, I8o

Rose, Macoun's, 220

Rose, Prickly, 2I9

Rose, Tiny, 22I

Rosewort, 216

Rush, Drummond's Bog, 86

Rush, Merten's Bog, 86

Rush, Parry's Bog, 86

Rush, Three-flowered Bog, 86

Rush, Small-flowered Wood, 87

Rush, Spiked Wood, 87

Rush, Scouring, 57

Rush Pipes, 56

St. John's-wort, Scouler's, 332
Salmonberry, 2I9

Sandwort, Blunt-leaved, I2I

Sandwort, Narrow-leaved, I2I

Sandwort, One-flowered, I2I

Sandwort, Vernal, I2I

Sarsaparilla, Wild, I67

Saussurea, Purple, 300

Saxifrage, Alpine, I42

Saxifrage, Alpine Brook, 144

Saxifrage, Common, I39

Saxifrage, Golden, 326

Saxifrage, Lyall's, I40

Saxifrage, Mountain, 2I I, 262

Saxifrage, Nodding, I40

Saxifrage, Purple-bracted, 142

Saxifrage, Spotted, I42

Saxifrage, Tall, I40

Saxifrage, Tufted, I42

Saxifrage, Wedge-leaved, I42

Saxifrage, Yellow, 325, 326

Sedge, Black, 86

Sedge, Dwarf, 85

Sedge, Merten's, 85

Sedge, Rock, 86

Sedge, Tussock, 85

Selaginella, Rock, 58

Selaginella, Small, 58

Serviceberry, Common, I52

Serviceberry, Thick-leaved, I 54

Shepherd's Purse, I33, I34

Shooting Star, 238

Sibbaldia, Creeping, 327

Silverberry, 334

Silver Weed, 327

Skunk Cabbage, Western, 305

Snowberry, I92

Solomon's Seal, False, IoI

Solomon's Seal, Star-flowered, IoI

Sorrel, Common, I 8

Sorrel, Field, i I8

Sorrel, Mountain, II7

Spearwort, Creeping, 316

Speedwell, Alpine, 288

Speedwell, Thyme-leaved, 289

Speedwell, Water, 289

Spiræa, Alpine, I52 
Spiræa, Birch-leaved, I50

Spiræa, Pink, 217

Spleenwort, Green, 5I

Spring Beauty, Alpine, I25

Spring Beauty, Lance-leaved, I24

Spring Beauty, Small-leaved, I25

Spruce, Engelmann's, 67

Spruce, White, 65

Squaw Weed, Northern, 358

Star Flower, - I86

Stickseed, Rock, 28r

Stitchwort, Long-stalked, I2I

Stitchwort, Northern, I22

Stonecrop, 324, 325

Strawberry, Wild, I54

Strawberry, Wood, I 54

Strawberry Blite, I20

Sundew, Long-leaved, I38

Sundew, Round-leaved, I37

Sunflower, Giant, 35I

Sweet Cicely, Crisp-leaved, I68

Sweet Cicely, Western, I68

Tellima, I46

Timothy, Alpine, 82

Thistle, Leafy, 20I

Thistle, Sow, 360

Thistle, Wavy-leaved, 300

Thistle, White, 20I

Twayblade, Broad-lipped, II2

Twayblade, Heart-leaved, I 2

Twin Flower, Northern, 249

Twisted-stalk, Pink, 205

Twisted-stalk, Short-stemmed, 207

Twisted-stalk, White, Io5

Vetch, American, 270

Vetch, Cow, 270

Vetch, Lentil, I6I

Vetch, Alpine Milk, 267

Vetch, Ascending Milk, 264

Vetch, Indian Milk, I6I

Vetch, Loose-flowered Milk, I6I

Vetch, Macoun's Milk, 267

Vetch, Purple Milk, 267

Vetch, Slender Milk, 267
Vetchling, Marsh, 27I

Vetchling, White, r63

Violet, Canada, I64

Violet, Dog, 274

Violet, Early, 272, 273, 274

Violet, Marsh, 274

Violet, Round-leaved, 334

Violet, Selkirk's, 274

Violet, Trailing Yellow, 334

Violet, Yellow, 333

Willow, Alpine, 74

Willow, Arctic, 75

Willow, Barclay's, 74

Willow, Barratt's, 74

Willow, Brown, 74

Willow, Dwarf, 74

Willow, Hairy, 74

Willow, Hoary, 73

Willow, Sitka, 75

Willow-herb, Alpine, I64

Willow-herb, Few-flowered, 225

Willow-herb, Great, 223

Willow-herb, Hornemann's, 224

Willow-herb, Mountain, 224

Willow-herb, Northern, 225

Willow-herb, Panicled, 225

Willow-herb, Water, 224

Willow-herb, Yellow, 336, 337

Wind Flower, I26

Wintergreen, Bog, 226

Wintergreen, Green-flowered, I74

Wintergreen, One-flowered, I74

Wintergreen, One-sided, I75

Wintergreen, Red, 228

Wintergreen, Small, I75

Witch's Broom, II6

Wood Nymphs, I58

Woodland Star, 216

Wormwood, Biennial, 200

Wormwood, Green, 200

Wormwood, Pasture, I99

Woundwort, 285

Yarrow, Dark-margined, I99

Yarrow, Woolly, I98

Yew, Western, 6r 



. 





\section{OK110 New York Botanical Garden Lubrary \\ Henshaw, Julia W./Wild flowers of the No \\ 35185001620896

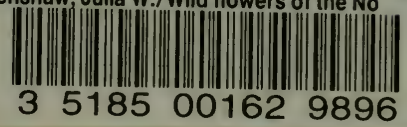

gen 
